\title{
THE GRAMA GRASSES: BOUTELOUA AND RELATED GENERA.
}

By David Griffiths.

\section{INTRODUCTION.}

\section{BASIS AND METHODS OF THE WORK.}

It was during the writer's connection with the University of Arizona in 1900 that work was begun on this group of plants. Preparations were then made to grow the plants under cultivation at the University in a region where the species predominate in the grass flora and form the main feed upon public and private stock ranges. A change of location caused a change of the plan of work. Since 1901 the writer's studies in the field have been carried on during extensive travel on behalf of the Department of Agriculture for the study of the public stock ranges and other purposes. In addition, travel has been performed extensively in Mexico under conditions which have allowed good opportunity for study.

The material in the following herbaria has been examined: United States National Herbarium, Gray Herbarium, herbarium of the Missouri Botanical Garden, herbarium of the Field Museum of Natural History, herbarium of the California Academy of Sciences (before the fire), and the private herbaria of Brandegee and Tracy. But while the collections in these herbaria were studied, the work is based mainly upon the material in the United States National Herbarium, and the specimens listed are almost entirely from that repository.

During his visit to Europe in 1907, Prof. A. S. Hitchcock secured, through the kindness of the directors of the herbaria there, fragments of several typical or authentic specimens for deposit in the National Herbarium. In other cases he procured photographs of type specimens and made notes and drawings that have greatly aided in the interpretation of the older names of the species. Further information has been obtained through correspondence with the directors of the botanical gardens at Kew and Berlin, to whom acknowledgments are due for their courtesy. 
The drawings accompanying this paper were prepared by Mrs. Agnes Chase, to whom the writer is indebted for numerous notes upon the minute structural details of the species. The half tones, except plate 69 , are from photographs taken by himself, and now the property of the United States Department of Agriculture.

\section{ECONOMIC IMPORTANCE OF THE GRAMA GRASSES.}

It is doubtful whether there is another group of native pasture grasses which is of as much economic importance as this, when both quality and quantity are considered. In the northern prairio region Bouteloua gracilis forms a very large part of the so-called "buffalo-grass formations," and makes a very fair sod over thousands of square miles. The arable lands upon which this species forms a good turf, however, are rapidly being broken up and devoted to ordinary farm crops, so that in the north the areas of grama have been very much reduced in the last 20 years.

In the arid Southwest, where the species are not turf formers, except at an altitude of 5,000 to 7,000 feet, the grama grasses are nevertheless of great importance, including, as they do, species which not only inhabit this region, but which actually furnish the greater part of the fecd at altitudes from 7,000 feet down to the driest desert mesas and lowlands. It is a noteworthy fact that the species which produce not only the greatest amount of feed, but the best feed as well, occupy the higher levels. This is of course accounted for by the heavier precipitation.

The conditions upon the highland of Mexico are very much the same as in the southwestern part of the United States, the high tablelands being imperfectly sodded with Bouteloua gracilis, B. chondrosioides, $B$. filformis, $B$. radicosa, B. hirsuta, etc., and the lower levels producing varying growths of such species as $B$. barbata and 3 . aristidoides. The first group especially includes the main pasture grasses over very large areas.

The species are preeminently pasture grasses and have been so recognized since they were first studied. Lagasca called attention to thom in a very positive fushion as early as 1805 , and our early explorers were unstinting in their praises of the gramas. It not infrequently occurs, however, that many of the species enter quite largely into the composition of hay. Upon the prairies of the North Central States $B$.graeilis, formerly to a much greater extent than at present, was extensively cut with Agropyron smithii, Koeleria, and other prairie species. Farther south, in Nebraska, Kansas, Oklahoma, and northeastern New Mexico, $B$. curtipendula is more conspicuous, and $B$. hirsuta is also of some importance mixed with various species of Andropogon on sandy-loam soils. The most valuable species, however, aside from $B$. curtipendula, do not well adapt themselves to 


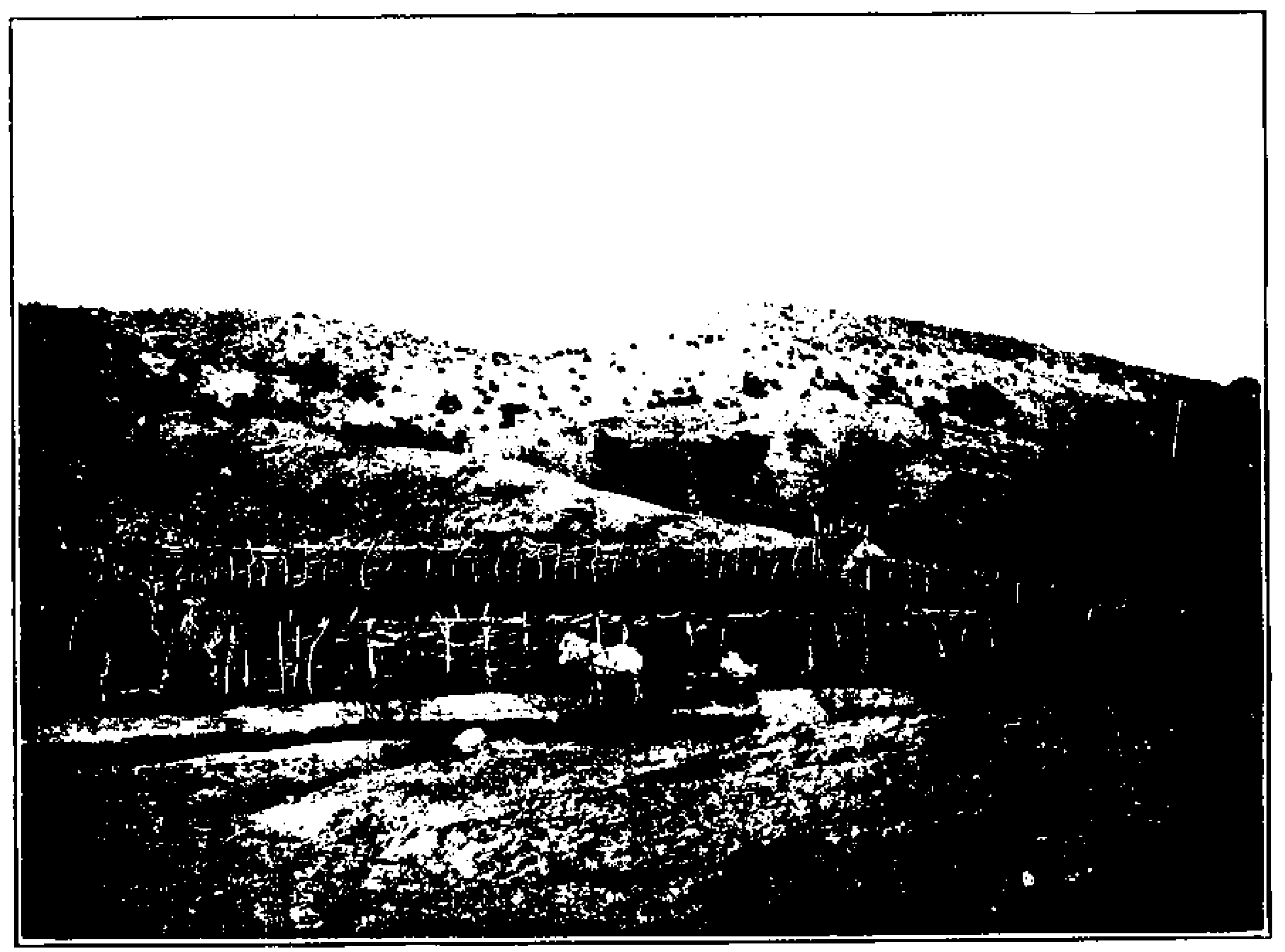

A. Closely Grazed Bouteloua Reglon in southern arizona.

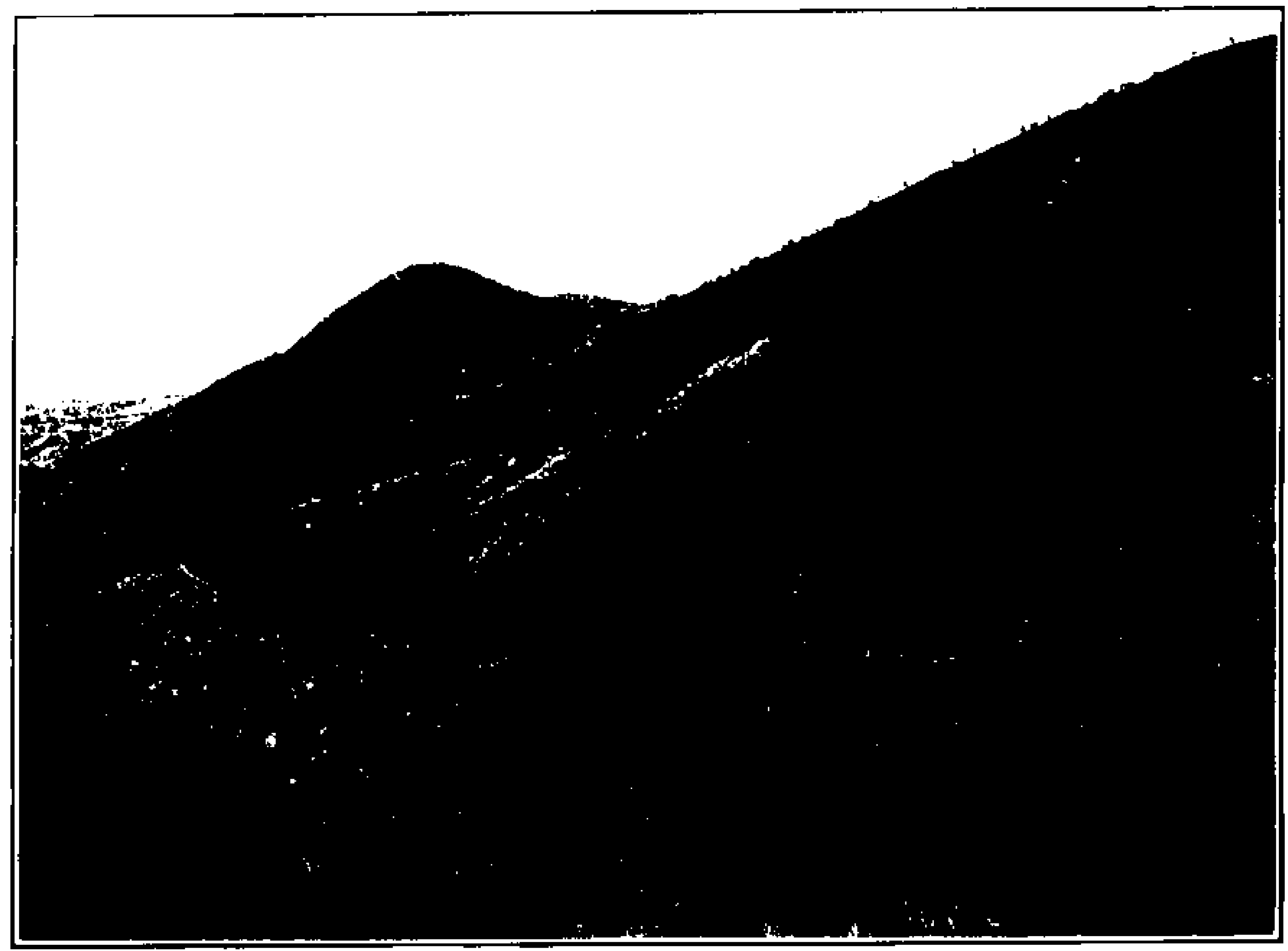

B. Habitat of Tall-Growing Species of Buuteloua in southern arizona. 


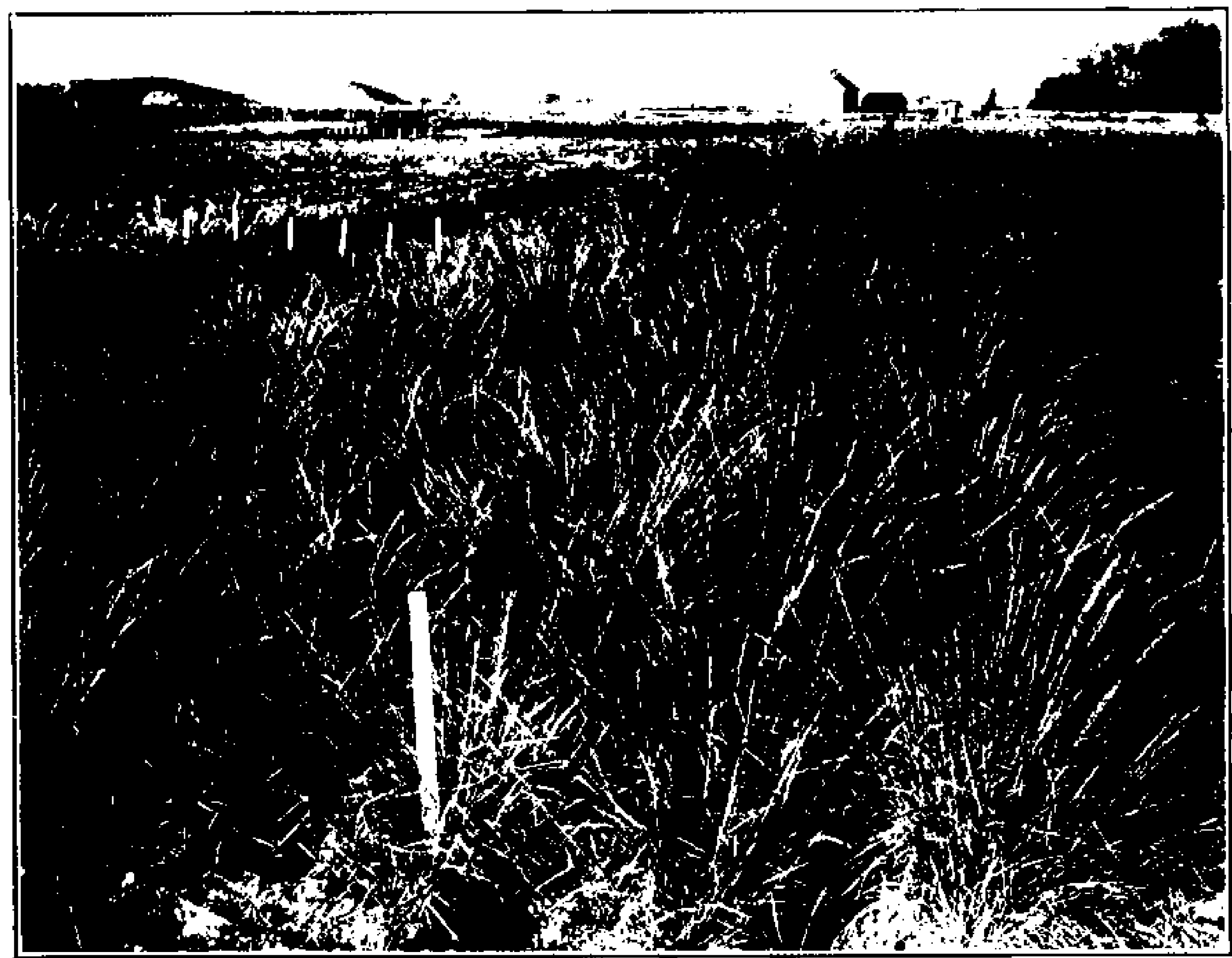

A. Bouteloua curtipendli. a : Michx.: Torr. in Cultivation.

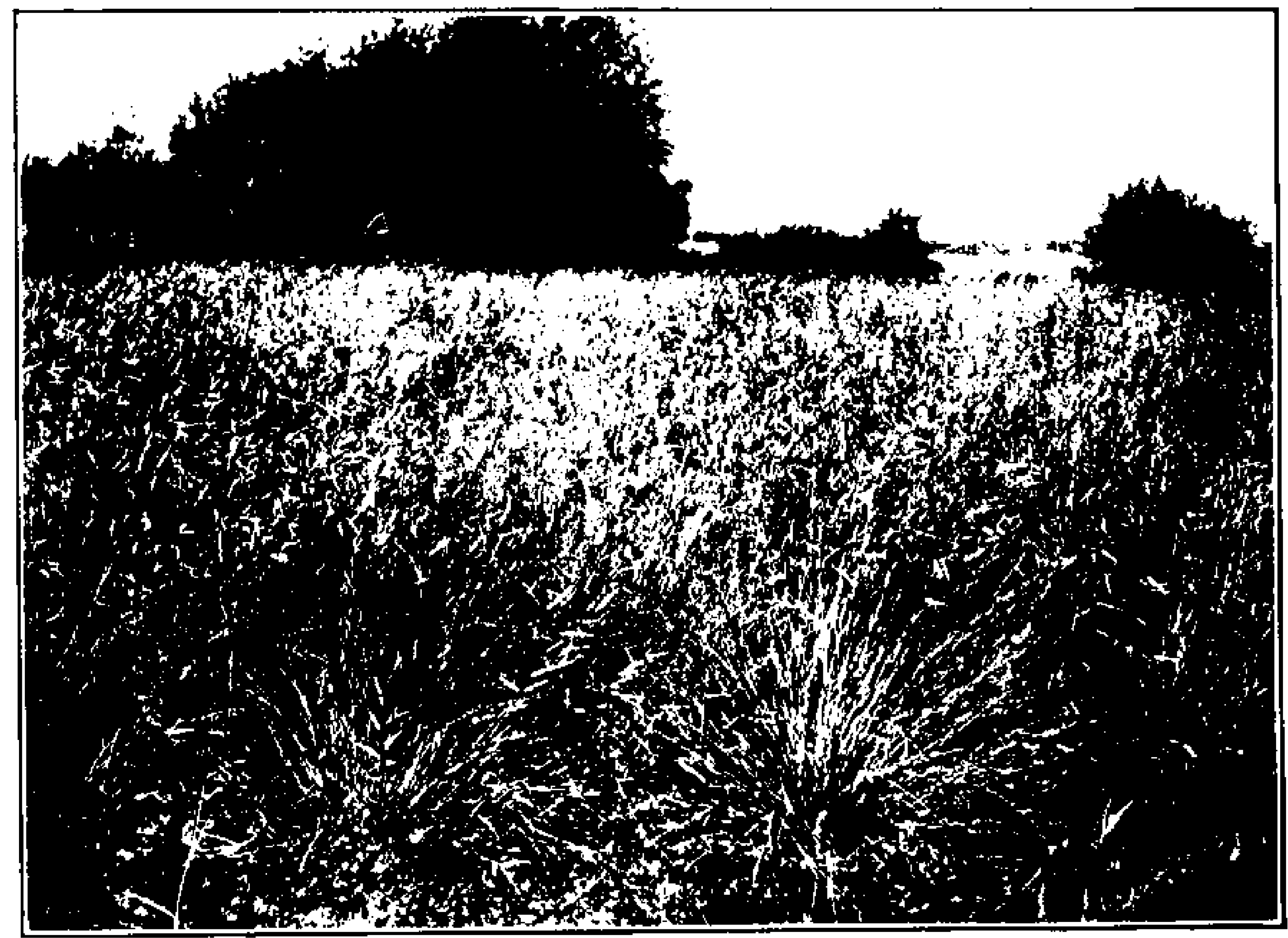

B. Buuteloua gracilis H. B. K. Lag. in Cultivation. 
cutting for hay. In the main the nutritious and valuable herbage of the grama grasses consists of their basal leaves, and these grasses are consequently adapted mainly to grazing.

In the main the perennial species very well withstand heavy grazing and the abuses incident to the open range method of handling stock. Indeed, there are few if any grasses that are superior to them in this regard. Bouteloua gracilis is the species of prime importance in the prairie region, and, together with $B$. chondrosioides, $B$. filiformis, $B$. radicosa, etc., is also important upon the higher lands farther south. No recorded experiences upon the behavior of these plants under cropping systems in the Southwest are known except the general observation that too close grazing reduces the vitality of the plants, and, if long continued, kills them out entirely $(\mathrm{Pl} .68, \mathrm{~A})$. Upon the northern prairies many observations have been made upon the behavior of the prairie grasses when cut for hay. The extent and degree of cropping have been much more definitely observed in the prairie region. In the Dakotas, Bouteloua gracilis withstands grazing very well, but if grazed closely for even one season it takes it two or three years to recover. It is the common experience that hay can not be cut on the upland prairies oftener than once every two years. In other words, the removal of the ground cover of one year's growth, as close as the mower takes it, sets the plant back at least one year, while burning is still more detrimental. But this applies to the prairie grasses in general.

\section{ADAPTABILITY TO CULTIVATION.}

Many efforts have been made to cultivate the different species of Bouteloua, especially during the grass-garden period of experimentation in this country, from about 1892 to 1900 .

The most promising of all the species for field cultivation is $B$. curtipendula (Pl. 69, A), not that it grows any more readily than the others, but on account of its size and habit. All the species respond readily to cultural treatment, but none of them have a good seed habit, a very important characteristic in an agricultural grass. The seed can not easily be even properly thrashed. All that can be done is to strip off the spikes, which separate readily from the panicle upon maturity. The whole spike has been invariably sown. In $B$. gracilis and allied forms the spikelets readily separate from the spikes, but even here it would be impracticable to attempt to secure clean seed.

Explanation of PLATE 68.-A. A reglon in which about half a dozen speeles of Bouteloua grow in profusion whenever summer rains are seasonable, in spite of the fact that it is continuously closely grazed. B. Scene In the Santa Rita Mountains, Arizona. Bouteloua curtipendula and tall forms of B. hirste and B. radicosa predominate, mixed with species of Leptochloa, Andropogon, Heteropogon, Mublenbergia and Panicum.

Explanation of Plate 69.-A. Bouteloug curtipendula. B. Boutelona gracilis. Both growing at Walla Walla, Washington. Photographs by Leckenby. 
The spikes of many of the species also drop off very readily when they approach maturity, and it is thus difficult to save the seed. So pronounced is this tendency in some species that it is impossible to prepare good herbarium specimens of plants in the mature state. This accounts for some of the taxonomic errors that have crept into our conceptions of the species. Collectors have commonly selected plants which could be made into good herbarium specimens, or, having collected mature ones, the spikes have been lost.

Bouteloua gracilis ( $\mathrm{Pl}$. 69, B) makes a splendid turf when sown thickly and well cared for. In some places upon tho native prairies and foothills of the Northwest beautiful natural turfs of this and Bulbilis are common. Although the quality of the turf is good it has the disadvantage of being green but for a short season.

In short, it is more than probable that, because of tho lack of good seed habits in this genus, even the most valuable species can not become of importance in cultivation, although good yields of hay can be secured from B. curtipendula at least (Pl. 69, A), and good stands can be secured with any of the other perennial valuable species if the seed be secured and sown thick enough.

\section{DISTRIBUTION.}

It is exceedingly difficult to give any definite and concise information regarding the altitudinal distribution of the species. Bouteloua gracilis is at home upon the prairies at an altitude of 1,000 feet, and, as we have seen, the same form occurs at 7,000 feet or more in the San Francisco highland of Arizona, and at much lower levels in the Santa Rita Mountains, while the taller form grows as low as 4,000 feet in the Santa Rita Mountains of Arizona. Precipitation is a much more important factor than altitude. So far as temperatures are concerned, B. gracilis endures $-40^{\circ} \mathrm{F}$. in the northern plains and makes a good growth in nearly frostless regions upon the highlands of central Mexico, while it sometimes endures a maximum of $100^{\circ} \mathrm{F}$. in the summer season.

In a circumscribed Bouteloua area there is quite a well-marked zonal distribution of some of the species (Pls. 68, B; 70, A, B; $71, A, B)$. As an example may be mentioned the region north of

Explanation of Plate 70.-A. Scene from north of the Sunta Rita Mountains in southern A fizona. In the foreground $B$. aristidoides predominates and $B$. parryi is common. A little farther out $B$. rothrockii and $B$. filformis are the prevailing spectes. On the lower portion of the steep slopes $B$, curtipendula and $B$. hirsuta are very. abundant, the former reaching an altitude of 5,000 feet, about the highest points at the left of the picture. A bout one-third way up the sides of the mountains to the right B. radicosa is abundant, while on southern exposures at the altitude of the small cone in center of picture $B$. eludens oceurs sparingly. B. A portion of the same area close to the mountains to the right, as seen in the spring of the ycar. Compare these with plate 75, B. It will be seen that the crop of grass, mainly Bouteloun, is all caten off and there is now a crop of annusl weedy plants consisting mainly of Plantago, Pectocarya, Eschscholtzin and a few small annual composites.

Explanation or PLate 71.-A. A closer vlew of ground shown in the left-hand part of plate 70, A, showing summer condition of region similar to that shown is plate 70, B. The gramas in the foreground ane malnly $B$. curlipendula, $B$. hirsuta, $B$. fulformis, and $B$. eriopoda. Dasylirion trheleri also shows prominently. B. Scene in the Altar Yaltey, Arizona, Baboquivari Poak in the leackground. Iu the foreground are shown B. rothrockit, B. barbata, B. aristidoides, and B. filiformis. 


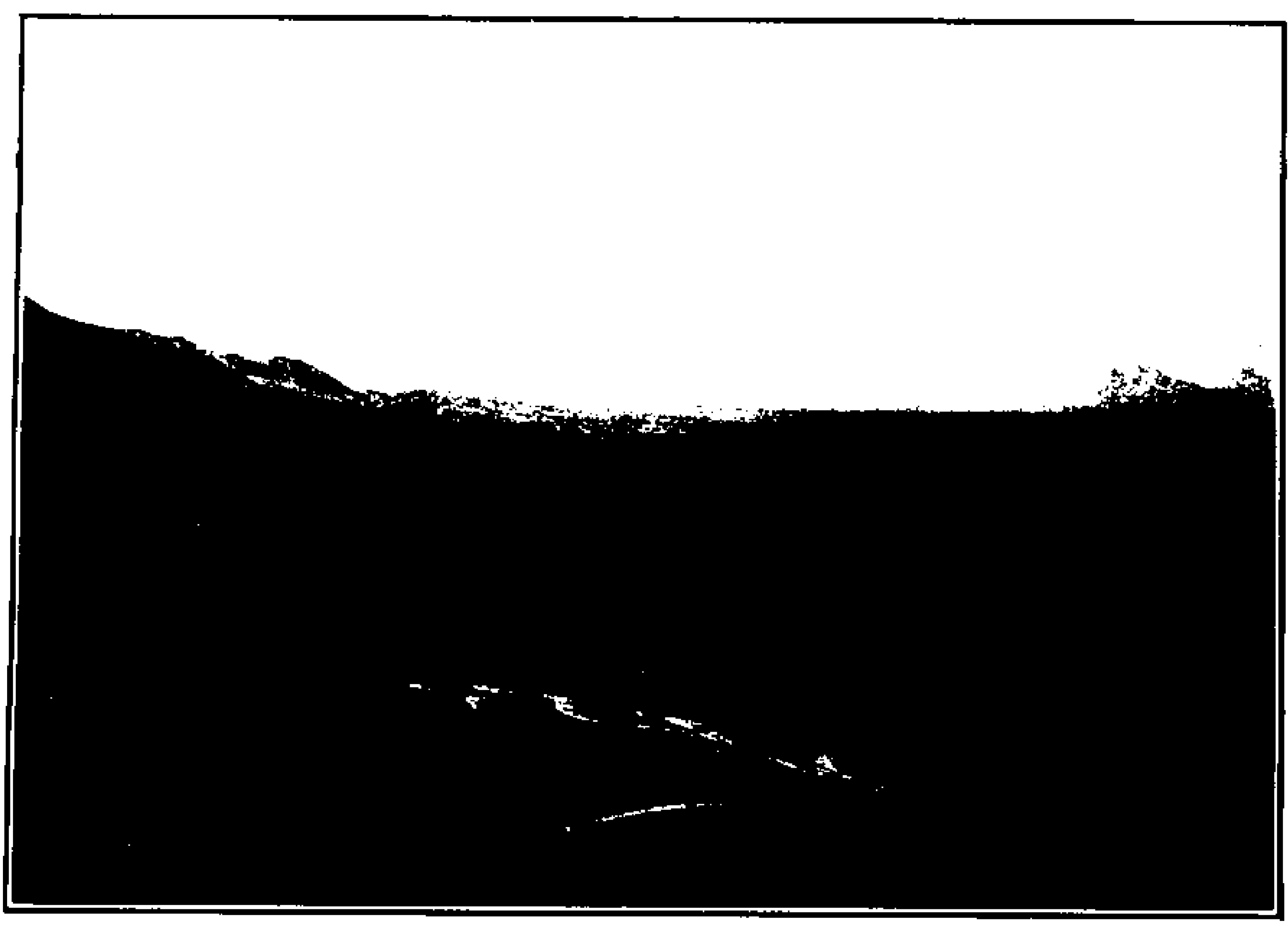

A. General View of a good bouteloua Region.

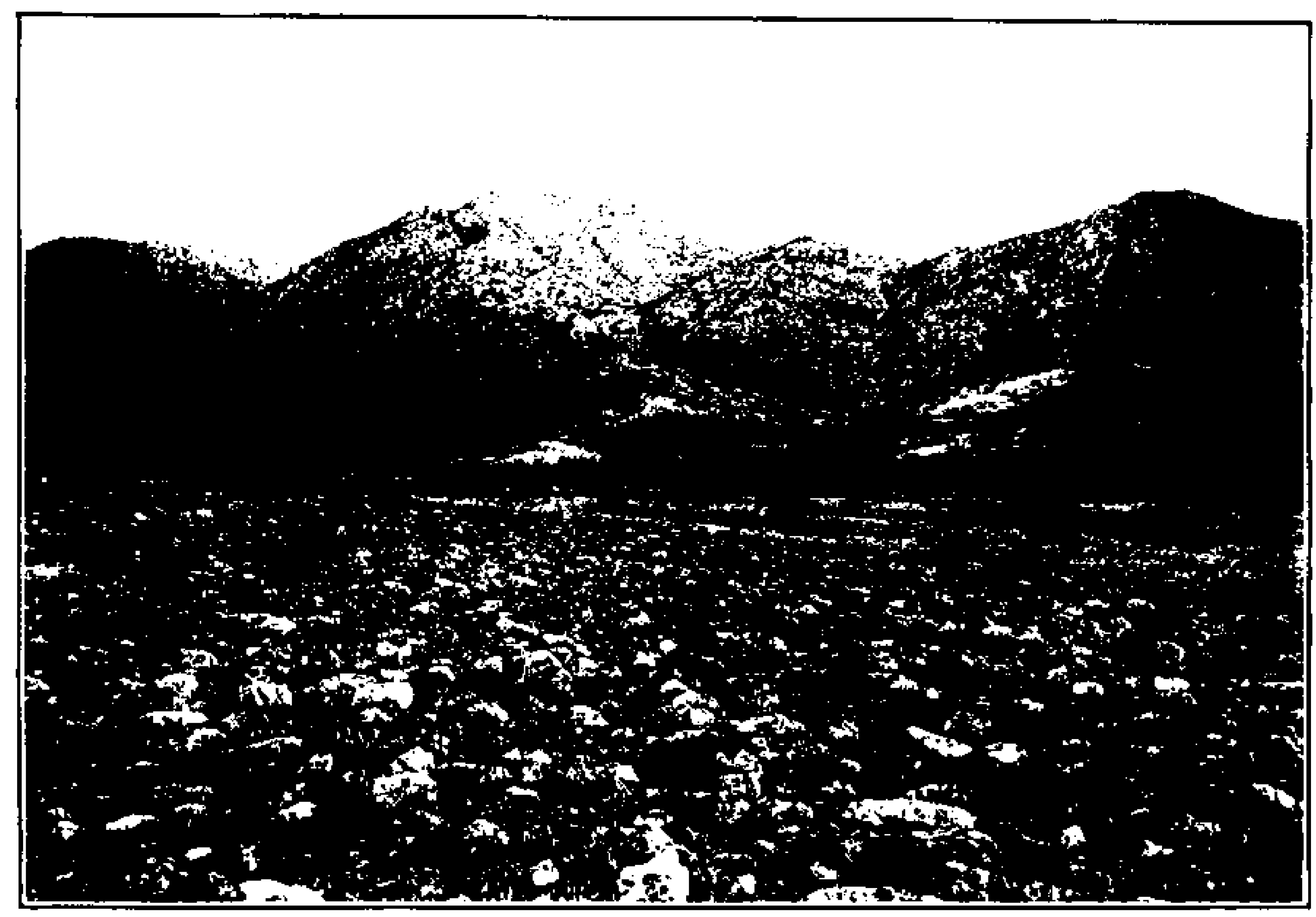

B. Spaing View of a Bouteloua Region closely Grazed. 


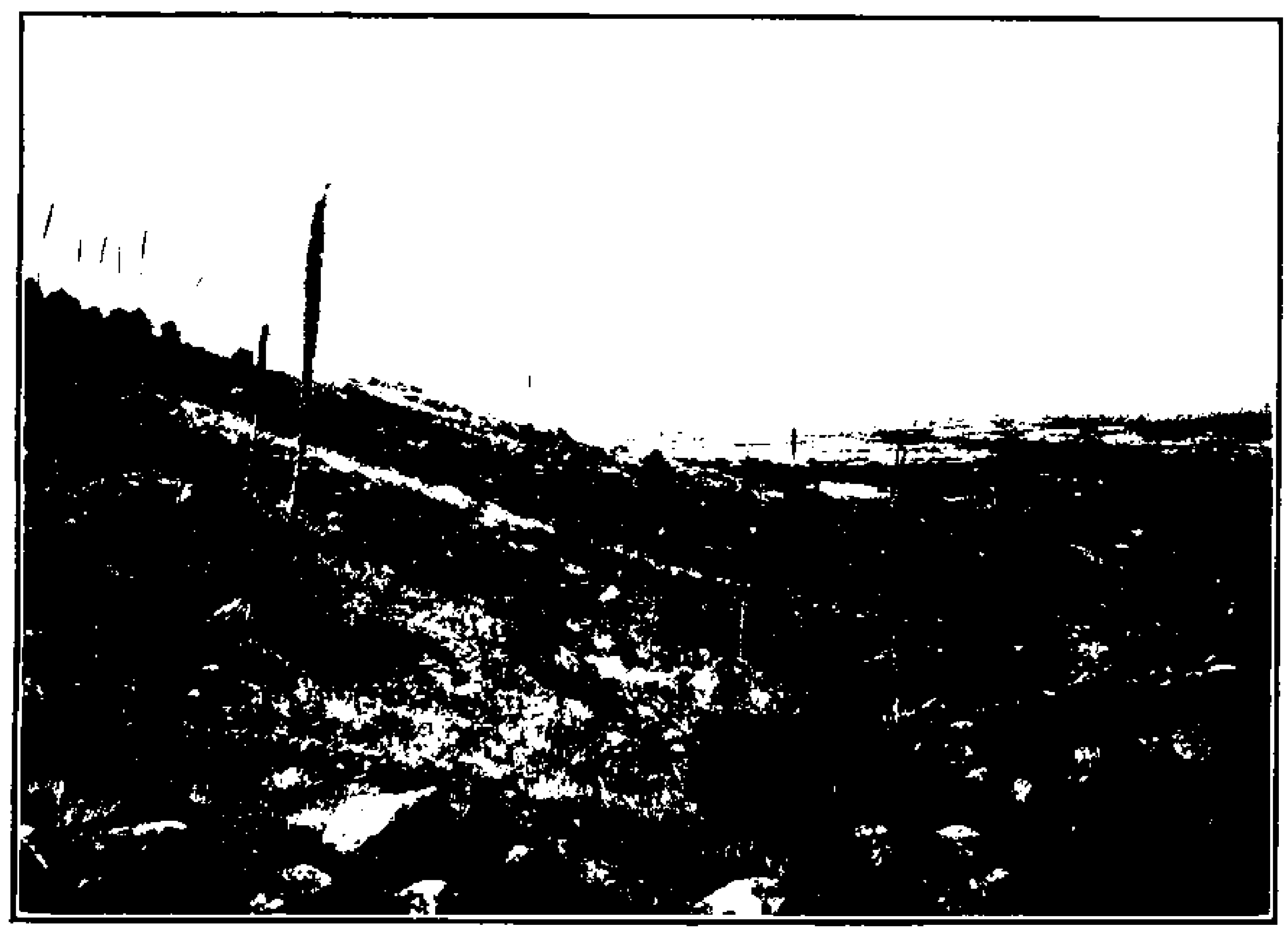

a. Typical View in a bouteloua Region, Showing a Variety of species.

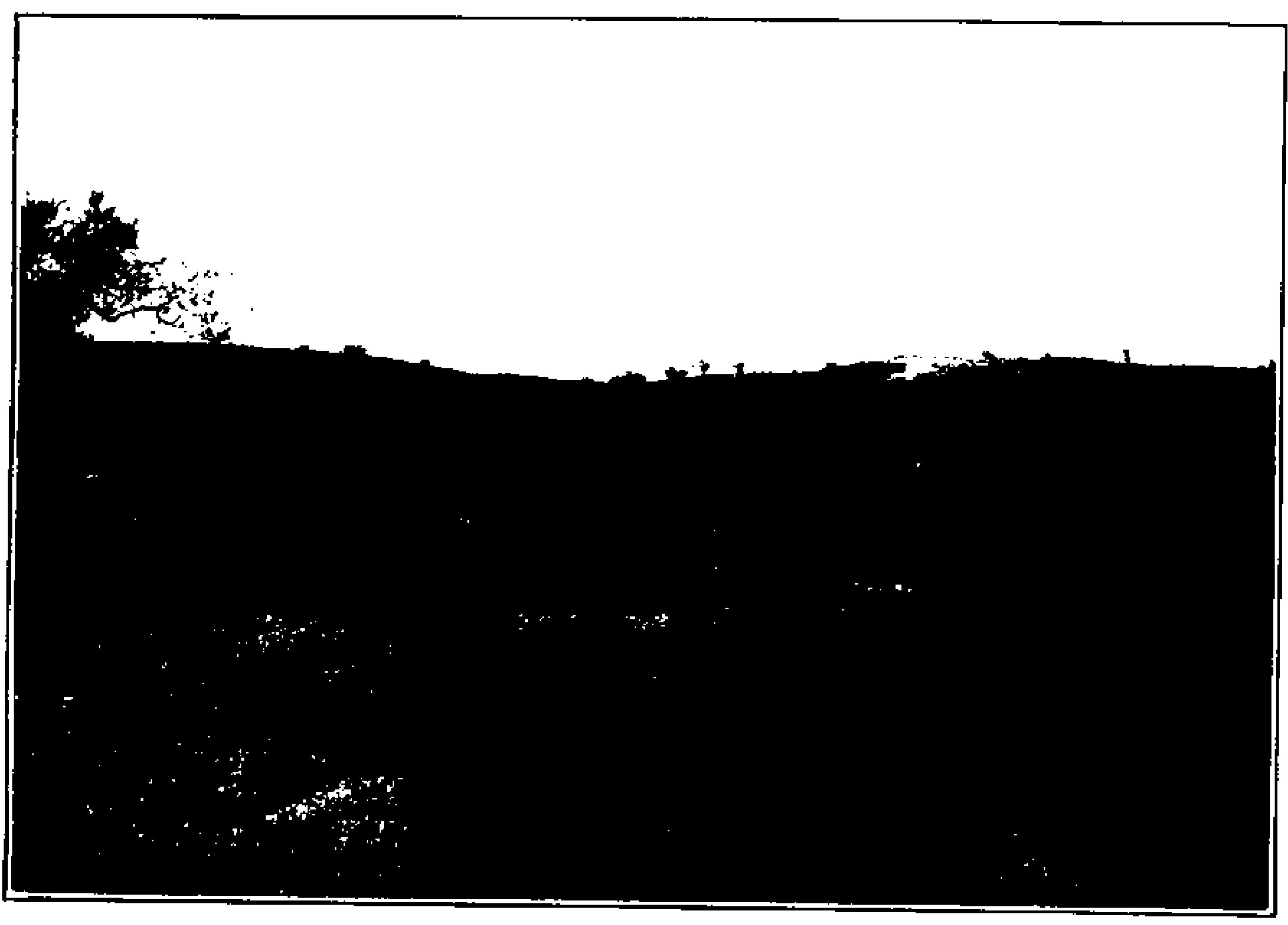

B. Bouteloua Region with a Different Soll and Different Species. 
the highest point of the Santa Rita Mountains of Arizona. From the 4,500 to the 5,000 feet level on the north side of this mountain $B$. radicosa is abundant. From about 4,500 feet down to 3,800 feet $B$. filiformis is commonly the prevailing species. From 3,800 to 3,400 feet $B$. rothrockii is often the most important plant, and it goes here as low as or lower than any of the other perennial species. Throughout this entire range, from 4,500 to about 3,500 feet, $B$. curtipendula may be found, but usually only upon the rougher lands, and it increases in importance upward, becoming the most important species upon the rocky upper foothills at 4,000 feet. Bouteloua aristidoides, on the other hand, is of wide distribution and may be found from the upper Bouteloua limit to the lower mesas (Pl. 67, facing p. 343), and even across them clear to the lower Colorado and into the Salton Sink below the level of the sea. Its greatest development is in the lower part of the perennial grass region, about the 3,500 feet level. It is found, in occasional years only, where there is a temporary accumulation of flood water, also in favorable places in the mesas, where the regular annual accumulation commonly produces perennial species of Hilaria. In this general Bouteloua belt, mostly at about 4,000 feet, may be found scattering patches of B. parryii, B. eludens, and B. eriopoda, and, especially below, B. barbata is frequently met with.

Roughly speaking, the great Bouteloua region of the world extends from Saskatchewan and Manitoba southward between the Mississippi River and the Continental Divide. The western border crosses the Divide in Wyoming, extends into the southern Great Basin region, and strikes the Pacific coast at about the Mexican boundary. In Mexico the grama grasses extend from coast to coast, reaching their greatest development upon the highland, and disappearing entirely in tropical situations of uniform heavy humidity. They are especially abundant and important in those elevated regions which have a heavy summer precipitation and are comparatively dry the rest of the year. Bouteloua curtipendula is common in the eastern United States and $B$. hirsuta is prominent in portions of Florida.

The writer's knowledge of South American species is based entirely upon a study of meager collections which do not warrant any conclusion other than that the species appear to be more or less common in the Cordillera region. $\Lambda$ few species are of frequent occurrence in portions of the West Indies and other continental islands. 


\section{ILLUSTRATIVE MATERIAL.}

Field studies have brought together sufficient material in the group to warrant the distribution of a set of specimens illustrating the writer's conception of the species. These sets, so fur as material is available, are deposited in the leading accessible consulting herbaria.

A total of nine sets have been put up and deposited us follows:

United States National IIerbarium, Washingtor, D. C.

Gray Herbarium, Cambridge, Mass.

New York Botanical Garden, New York City.

Missouri Botanical Garden, St. Louis, Mo.

Ficld Museum of Natural Hiatory, Chicago, Ill.

University of California, Berkeley, Cal.

Royal Botanic Gardens, Kew, England.

Königlicher Botanischer Garten, Dahlem-Steglitz bei Berlin, Germany.

Muaéum d'Histoire Naturélle, Paris, France.

Beginning on page 425 will be found a list of the species which are being thus distributed, together with designation of the sources of the material. The types of the new species here proposed are contained in the set deposited in the United States National Ierbarium at Washington. In some cases the numbers are distributed under other names thun those of the text because they were arranged before the work on the text was completed.

\section{LIMTTATION OF THE GENERA.}

The genus Bouteloua ${ }^{a}$ was established by Mariano Lalgasca in Variedndes de Ciencias, Literatura y Artes (Madrid) in 1805. So far as I am able to determine he has expressed in no way what species he considers typical of the genus, although an elaborate discussion is given of the characters and of the economic importance of the group as pasture grasses. Apparently the only way of fixing the type of the genus is to choose the first species listed. This method is as usual the most easily upplied in fixing the generic type, and under the application of this rule the name Bouteloun will have to stand for the genus, however that genus is limited, containing the first species, Bouteloua racemosa Lag., which is clearly the same species as the earlier described Chloris curtipendula Michx. Lagasca wrote another and more comprehensive treatise upon the sume genus eleven years later, in which $B$. hirsuta is the first species listed und $B$. racemosa the last. In this treatise Lagasca again fails to indicate what he considers the type of his genus. IIowever, the application to the 1805 paper of this arbitrary principle of priority of place is not here considered to be at all affected by the subsequent publication.

a Originally this was written Botelua, although Lagasca states that it is dedicated to two Spanish gardeners, brothers, of the name of Boutelou. In a later paper (Gen. \& Sp. Nov. 1816) he adopts the spelling used bere. 
This is not the method followed in some of the recent literature of the grasses, and it is in no closer accord with recent practice than is the comprehension in one genus of all the species here included. Kunth ${ }^{a}$ was the first excessively to divide the group, and to some extent his work has been adopted by some recent authors. Others have contented themselves with adopting Kunth's genera as subgenera or sections. Were I to divide the genus, however, the lines laid down by Kunth would have to be somewhat modified as has been done by Nash. ${ }^{b}$ Kunth includes in Dinebra Bouteloua curtipendula and $B$. aristidoides as well as $B$. radicosa, $B$. repens, and $B$. chondrosioides, while for Aristida americana of Linnæus, the West Indian representative of our $B$. filiformis, which is a variant very close indeed to that species, the monotypic genus Heterostega of Desvaux was adopted. The other monotypic genus, Polyodon H. B. $\mathrm{K}$., should also, without doubt, be included with the radicosa-repens section of the genus to which Kunth applied the name Dinebra Jacq. Chondrosium on the contrary is better delimited and could stand on its merits without change better than the others.

Although Kunth formally recognized all these genera it was against his best judgment that this was done. He specifically states that in his opinion these genera should be united. The disposition made here was decided upon before the opinion of Kunth was discovered. His opinion ${ }^{c}$ corresponds very closely indeed with my own preference.

There has been much difference of opinion as to the relationship of Cathestecum ever since it was established by Presl. ${ }^{d}$ By Bentham and Iooker it was placed in the Zoysiese along with Aegopogon, which closely resembles some species of Bouteloun and probably should stand closer to that genus than it is now placed. By Hrckel Cathestecum is included in the Festuceae. But the species of this genus in general aspect as well as in minuter details very closely resemble some species of Bouteloua. The resemblance in the field is so great that botanists usually refer their collections of Cathestecum to Bouteloua.

The group differs from the remainder of the grama grasses in having 3 spikelets in the spike, in the reduction of the first glume in one or all of the spikelets, and in a tendency to multiplication of awns by division of the nerves of the lemma of the upper florets.

$a$ H. B. K. Nov. Gen. \& Sp. 1: 171-176. 1816.

$b$ Small, Fl. Southeast. U. S. 137. 1903.

c H. B. K. Nov. Gen. \& Sp. 1: 173. 1816. The last paragraph on the page rearls as follows: "Heterastega vix genue distinctum, habitus Dinebrae, characteres Chondrosii; genera Heterostegae, Chondroeii et Polyodontis, ut mea fert opinio, valde artificialia, et aptius generi Dinebrae conjungenda sunt." .

$d$ Rel. Haenk. 1: 295. pl. 42. 1830. 
Pentarrhaphis, established by Kunth, ${ }^{a}$ was based upon $P$. scabra, which remained practically unknown until Hackel and Scribner identified it and added another species in $18900^{b}$ Since the addition of this second species it is best separated from the other genera by its spikes of 2 spikelets, one of which is aborted in P. scabra. There appears to be no other character upon which it can be segregated.

The monotypic genus Triaena ${ }^{c}$ is separated by its spikes of a single spikelet. With it will naturally fall Bouteloua uniflora when this character alone is considered, but the latter species is manifestly very closely related to $B$. curtipendula. Indeed, it is quite probable that further collections may prove that the former is simply an unusual form of the latter.

\section{BIBIIOGRAPHICAL NOTES.}

There has always been a question regarding some of Lagasca's names. Kunth's figures, ${ }^{d}$ however, are recognizable by one who is familiar with the species. The examination of a large number of authentic specimens has elucidated many obscure names, but there are a fow more that, unless more evidence can be found, will always remain doubtful species.

Cervantes's ${ }^{e}$ names published under the genus Erucarin have been rejected almost in toto. It would be very desirable to reler these names properly, although it is not probable that they would seriously affect the synonymy.

The next most difficult work to interpret is that of Fournier. $f$ Fragments of specimens cited from European herbaria have assisted greatly in settling doubtful questions. The examination of a cited number, however, is not sufficient to identify Fournier's species, for different species are found at times under the same number in different

$a$ In II. B. K. Nov. Gen. \& Sp. 1: 178. pl. 60. 1816.

$b$ Bull. Torrey Club 17: 233. pl. 108. 1890.

$c$ II. B. K. Nov. Gen. \& Sp. 1: 178. 1816.

d H. B. K. Nov. Gen. \& Sp. $1: p l, 51-60.1816$.

e La Naturaleza $1: 347.1870$.

$f$ Mex. Pl. $2: 1881$. There is a difference of opinion about the proper date to eite for this work. It seems desirable to bring together here the available facts which appear to be as follows:

1. Fournier read a paper before the Academy of Sciences of Paris, June 10, 1878, in which he stated that this work was completed and in which he gave data regarding the distribution and number of species. (Compt. Rend. Acad. Sei. (Paris) 86: I441. 1878.)

2. Bentham received in 1881 a copy marked "pronf aheets" (see Hitchcock and Chase, Contr. Nat. Herb. $15: 49.19$ l0) with neither index nor title page. (Journ. Linn. Soc. Bot. $19:$ 14-134. 1881.)

3. Hackel also received a copy of the work excluding title page and terminating with page 144 (18 sheets) in 1881. 
herbaria. The specimens in the herbarium of the Museum of Paris must be taken as the basis of his work, but some of the numbers cited have not been found there and a few have not yet been found elsewhere.

\section{DESCRIPTION OF THE GENERA AND SPECIES.}

\section{THE BOUTELOUAE.}

Plants annual or perennial, cespitose or stoloniferous, with spikes one to many, mostly several to many, arranged in unilateral racemes, the spikelets mostly nearly ressile in two rows on a flattened rachis which may be simple or forked distally, but so twisted upon their very short peduncles as to appear more or less unilateral especially when young; spikelets mostly 2 -flowered, one of the florets rudimentary, in some cases an additional 1 to 3 rudiments; lemmas 3-nerved, 3-awned, with a 2-nerved mostly ehorter-awned palet.

\section{KEY TO THE GENERA AND SPECIES.}

Spikes consisting of less than 3 spikelets (except in $B$. unifora).

Spikes consisting of 1 spikelet; rudimentary spikelet trifid. (Triaena, p. 354.)

Spikes consisting of 2 spikelets, both perfect or 1 rudimentary. (Pentarrhaphis, p. 355 .)

One spikelet rudimentary, represented by 2 seta only .............................. 1. P. scabra.

Both spikelets fully developed.............. 2.P. polymorpha.

Spikes consisting of 3 or more spikelets.

Spikes consisting of 3 spikelets. (Cathestecum, p. 358.)

Plants annual ............................. prostratum.

4. Bentham states (loc, cit.) that he is bound to treat it as having taken date, and Hackel used it in the preparation of his part of the grasses in Martiue's Flora of Brazil, published July 1, 1883. (Bot. Centralb. $28: 232.1886$. .)

5. Hemsley (Biol. Centr. Amer. Bot. 3 : November, 1885) cites it freely and to the end of the grase volume from the Bentham copy.

6. The copies of Bentham and of Hackel were not galleys nor even page proofs in the ordinary sense, but the signatures in sheets as they came from the press. In other words, the work had taken form and was printed in 1881 .

7. Hackel did not receive the index until 1886 , although he applied to the printing office for it in 1884. He thinks that the title page was received with the index. (Letter to Hitchcock, Aug. 8, 1906.)

Dr. Barnhart in response to a request for an opinion has, after reviewing the facts, summed up the matter as follows: "(1) Most grass specialists were able to consult Fournier's work from 1881. (2) They regarded it as published (not in a trade sense, but from a botanical standpoint), and cited it accordingly. (3) If we do not accept 1881 as the date, we open the question, in the case of each Fournier name that found its way deviously into botanical literature between 1881 and 1886 , whether it was adequately published or not. (4) We have enough questions relating to the adequacy of publication of plant names without needlessly burdening ourselves with such a large number of others. On the whole, therefore, I strongly favor 1881."

$9368^{\circ}-12-2$ 
Plants perennial.

Plants cespitose.

2. C. mullifidum

Plants stoloniferous.

Spikes dimorphous; stenile lemma clefi less than half way ................. $3 . r^{\prime}$ '. cretum.

Spikes not dimorphous; sterile lemma deft nearly to the base ............... \&. stoloniforum.

Spikes consisting of more than 3 spikelets. (But intcluding $B$. uniftora, which has but I spikelet.)

(Bouteloua, p. 363.)

Spikelets pectinately arranged at maturity (Sulogenus Chondrosium).

Spikes normally loss than 4.

Spike 1.

Plants annual.

Spikesconparatively thirrow. (Norib

American)................ I. H. procumbens.

Spikes comparatively wide. (South American)................. B. simplex.

l'lauta perennial.

Stoloniferous.................. 3. B. stolonifera.

Cespitose..................... 1. B. scorpioides.

Spikes normally 2, often $\perp$ or 3 , or even 4 , seldom more than 4 .

Glumes tuberculate; rathis prolonged beyond the spikelets as a lakked point.

Internodes lirsute-villous 5. B. hirticulmis, Internodes not hirute-villous...... . 16. B. hirsute.

Glumes not tuberrulite; nathis not prolonged.

('ulins annual..................... ;. B. grecilis.

('ulms in part peremial,

Gulms erect-branching........... s. B. brorisela.

Culms geniculate-branehing..... 9. B. romose.

Spikes normitly 4 or mors.

Glumes hairy-villous................. 10. B. parryi.

Glumes not hairy-villous.

Plants annual.

Awne of forlile lomma comparativerly

short .................... II, B. barbala.

Aw wh of farlike lommit romparatively

long.................... 12. B. armossa.

Plants perennial.

Low, 10 to $30 \mathrm{~cm}$. ligh

Rudiment naked............. 13. B. trinii.

Rudiment hairy-tufted........ I4. B. sonorne.

larger plants 30 to $50 \mathrm{~cm}$. high.

('ulms villous; stoloniferons..... 35. B. eriopoth.

('ulms not villous; cespitore.

Base delicate............ in. R. rolhrorkii.

lawe strong, harsh, scaly,

rhizomatons......... 17, B. Karwinskii.

a Forms of $B$, grarilis have luberculate glumes, but never a prolonged rachis. 
Spikelets not pectinately arranged. $a$ (Subgenus ATHEROPOGON.)

Spikea of 1 spikelet.

35. B, uniftora.

Spikes of more than 1 spikelet.

Plants annual.

Leaves and sheaths tuberculate-hairy.... 18. B. alamosana.

Jeaves and sheaths not tuberculate-

hairy

19. B. aristidoides.

Plants perennial.

Sheaths densely hairy............. 20. B. pringlei.

Sheaths not densely hairy.

Glumes densely hairy.

Sterile lemma trifid, long-awned. 21. B. chondrosioides.

Sterile florets two or three, with well developed lemmas

(variable)............ 22. B. cludens.

Glumes not densely hairy. (See continuation.)

(Continuation.)

Sterile florets distinctly 2 or more.

Plants stoloniferous.

23. B. megapotamica.

Plants cespitose.

Plants low, hairy

24. B. texana.

Plants tall, smooth.

25. B. lophostachya.

Sterile floret 1 or with additional rudimentary one.

Second floret trifid and naked, not glumaceous.

Lateral awns short.

Proximal spikelets not rudimentary

26. B. acuminala.

Proximal spikelets rudimentary ........... 27. B. vaneedeni.

Lateral awns nearly as long as central one......... 28. B. americana.

Second floret glumaceous.

Second floret mostly perfect, the first sterile.

Plants amooth 99. B. repens.

Plants more or less prominently papilloso-hairy.

Spikes and spikelets alike (Continental A merica).

Plante stout with harsh rhizomatous base. $30, B$, radicosa.

Plants more delicate, cespitose or genicu-

late........................ 31. B. filiformis.

Spikes and spikelets very variable (West

Indies)

32. B. heterostega.

Second floret sterile, the finst fertile.

Spikes about $12 \ldots \ldots \ldots \ldots \ldots \ldots \ldots$ 33. B. disticha.

Spikes more numerous.

Spikelet with rudiment of a third

floret................. 34. B. pilosa.

Spikelet with no rudiment of a

third floret............ 36. B. curtipendula.

a Immature forms of several species belonging here are likely to be looked for under Chondrosium. 
TRIAENA H. B. K.

Triaena H. B. K. Nov. Gen. \& Sp. 1: 178. 1816. A monotypic genus based upon T. racemosa.

Inflorescence linear, racemose, the spikes arranged in two rows on opposite sides of a flattened axis but so twisted upon their short delicate peduncles as to appear unilateral; spikes consisting of a single 2-flowered spikelet and a prolonged rachis, the lower floret perfect, the upper reduced to a 3-awned rudiment.

\section{Triaena juncea (Degv.).}

Triathera juncea Desv.; Beauv. Ess. Agrost. 40. pl. 9.f. 4. 1812. Beauvois's figures, although diagrammatic, appear to me well to characterize the plant. Desvaux a distinguishes this from his $T$. americana which is Aristida amerirana $L$.

Triaena racemosa H. B. K. Nov. Gen. \& Sp. 1: 179. pl. 61. 1816. Easily identified from the figures and description. See also Roem. \& Schult. Syst. Veg. 2:421. 1817.

Eutriana triaena Trin. Gram. Unifl. 239. 1824. Based upon Triaena racemosa $\mathbf{H}$. B. $\mathrm{K}$.

Atheropogon triaena Spreng. Syst. Veg. 1:293. 1825. Based upon Triaena racemosa $\mathbf{H}$. B. K.

Atheropogon domingensis Spreng. Syst. Veg. 1:293. 1825. Based upon Triathera juncea Desv.

Dineba cristata Presl, Rel. Haenk, $1: 293.1830$. The type, in the Bohemian National Museum at Prague, has been examined.

Triathera racemosa Desv. Opusc. 72. 1831. Based on Triaena raccmosa $\Pi$. В. K. See also Roem. \& Schult. Syst. Veg. 2 : 421. 1817; Fourn. Mex. Pl. 2 : 141. 1881. Presl.

Triathera gracilis Fourn. Mex. Pl. 2: 141. 1881. I have no hesitancy in referring this to Triaena juncea, although Fournier says distinctly that his plant is not Triaena racemosa $\mathrm{H}$. B. K. Fournier cites "Eutriana racemosa Trin. Mse. in Herb. Petrop." as a synonym. All apecimens so named by Trinius belong to Bouteloua curtipendula. The first epecimen cited by Fournier is Berlandier's no. 1016 from ('ucrnavaca, Mexiro. This number in the herbarium of the Muséum at Paris, as well as in the herbarium at Vienna, belongs here without doubt. The latter is labeled Eutriana racemosa Trin. (See Eutriana racemosa Trin.)

Bouteloua triaena Scribn. Proc. Acad. Phila, 1891: 307. f. $2 . b$ 1891. I3ased upon Triaena racemosa H. B. K. See also Bull. Torrey ('lub 18: 314.1891.

1)ESCRIPTION.

A cespitose, erect, sparingly hairy perennial, forming strong, conspicuous bunches among other grasees or more rarely continuous pure growths approaching a rough, bunchy turf; culms sparingly branched, erect or when luxuriant geniculate, 40 to $50 \mathrm{~cm}$. high; sheaths rather close, striate, covered with long, seattered, papillose hairs, these more numerous in plants of exposed places; blades narrow, comparatively short, the lower about $7 \mathrm{~cm}$., the upper $5 \mathrm{~cm}$. long, erect, acuminate, rigid, involute, smooth save for the regularly arranged, marginal, papillose hairs; panicle slender, racemose, 7 to $10 \mathrm{~cm}$. long, the spikes bilateral but usually so curved on their peduncles as to appear unilateral; spikes variable in number, 20 to 70 , about $7 \mathrm{~mm}$. long at an thesis but becoming 10 to $12 \mathrm{~mm}$. long by the development of the awns of the rudiment,

a Journ. de Bot. 1: 67. 1813.

$b$ In Beal's Grasses of North America (2: 427,1896$)$ this figure is incorrectly trantferred to $B$. texana. 
consisting of one epikelet, the rachis prolonged 1 to $2 \mathrm{~mm}$. beyond; spikelet 2-flowered, the lower floret perfect, the upper reduced to a 3-awned rudiment; glumes minutely hispidulous on the keel, acuminate, the first 2 to $3 \mathrm{~mm}$., the second 4 to $5 \mathrm{~mm}$. long, very short-awned or merely acuminate; lemma ovate, indistinctly 3-nerved, especially below, 3-toothed at the apex, rarely awned; palet 2 -nerved with 2 short awns at the apex; rudiment consisting of 3 scabrous awns about $7 \mathrm{~mm}$. long, upon a naked stipe $3 \mathrm{~mm}$. long; caryopsis not seen. (FIqURE 19.)

This species is common upon the highlands of central Mexico, especially from Hidalgo to Oaxaca, and extends far into Guerrero and western Jalisco. It is well represented in herbaria by Pringle 7482, 870, and 9573 , and Nelson 1842, which are typical. Miguel Bang's no. 1307 in Plantae Bolivianae, from Sorata, Bolivia (distributed by Britton and Rusby), and Schop's no. 740 are both immature. The latter probably belongs here, but the former is doubtfully referred to this species.

\section{HERBARIUM BPECIMENB.}

Mexico: Pringle 9573,El Salto; 8708, near Jojutla; 4792, Los Sedas, Oaxaca. Nelson 1842, Dominguillo; 1542, Valley of Oaxaca. Conzatti \& Gonzalez 265, Lo6 Sedas. Schott 740, Yucatan.

PENTARRHAPHIS H. B. K.

Pentarrhaphis H. B. K. Nov. Gen. \& Sp. 1: 177. pl.60.1816. A monotypic genus based upon $P$. scabra.

Polyschistis Preal, Rel, Haenk. 1: 294. pl. 41.f.12-18.1830. Based upon $P$. paupercula.

Strombodurus Willd.; Steud. Nom. Bot. ed. 2, 2: 299. 1841. This is listed as a synonym of Pentarrhaphis, and the single species $S$. gracilis Willd, is referred (page 647) to Pentarrhaphis scabra $\mathbf{H}$. B. K. (The initial letter of the latter generic name is misprinted " $D$ ".)

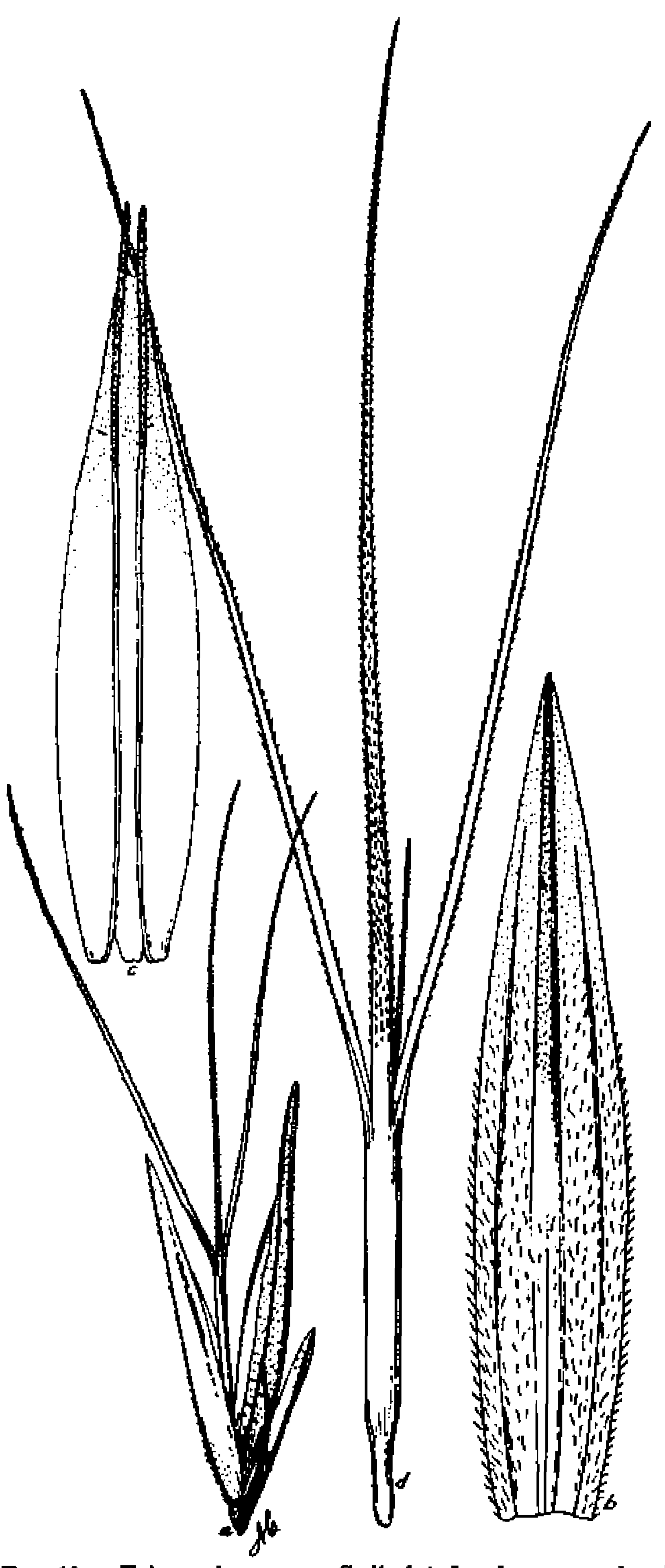

FIG. 19.-Triaena funcea. a, Spikelet; $b, c$, lemms and palet of first floret; $d$, rudiment. $a$, Scale $5 ; b-d$, scale 10 . From Grifiths 8122 .

Species with small, woolly spikes consisting of 2 spikelets, one of these sometimes aborted, approximate on a rachis ending in a forked or bifid prolongation; first glume of each spikelet reduced to scarcely more than a straight awn; these together with the bifid rachis appearing like a cluster of awns at the base of the spikelet; spikelets 2-flowered. 


\section{Pentarrhaphis scabra H. B. K.}

Pentarrhaphis scabra H. B. K. Nov. Gen. \& Sp. 1: 178. pl. 6\%. 1816. Authentic material has not been found, but the figures are good and leave no room for doubt as to the identity of the species. See also Bull. Torrey Club 17:233. pl. 108. 1890.

Atheropogon pentarrhaphis Spreng. Syst. Veg. 1:294. 1825. Based upon Pentarrhaphis scabra II. B. K.

Eutriana pentarrhaphis Trin. Gram. Unifl. 239. 1824. Based upon Pentarrhaphis scabra H. B. K.

Polyschistis paupercula Presl, $a$ Rel. Haenk. $1: 294 . p l .41 . f .12-18$. 1830. The gures and description identify the plant.

\section{DESCRIPTION.}

An ereet, cespitose perennial about $30 \mathrm{~cm}$. high; culms erect, commonly branched from the upper nodes; sheaths loose, striate, the ligule a short, dense fringe of white

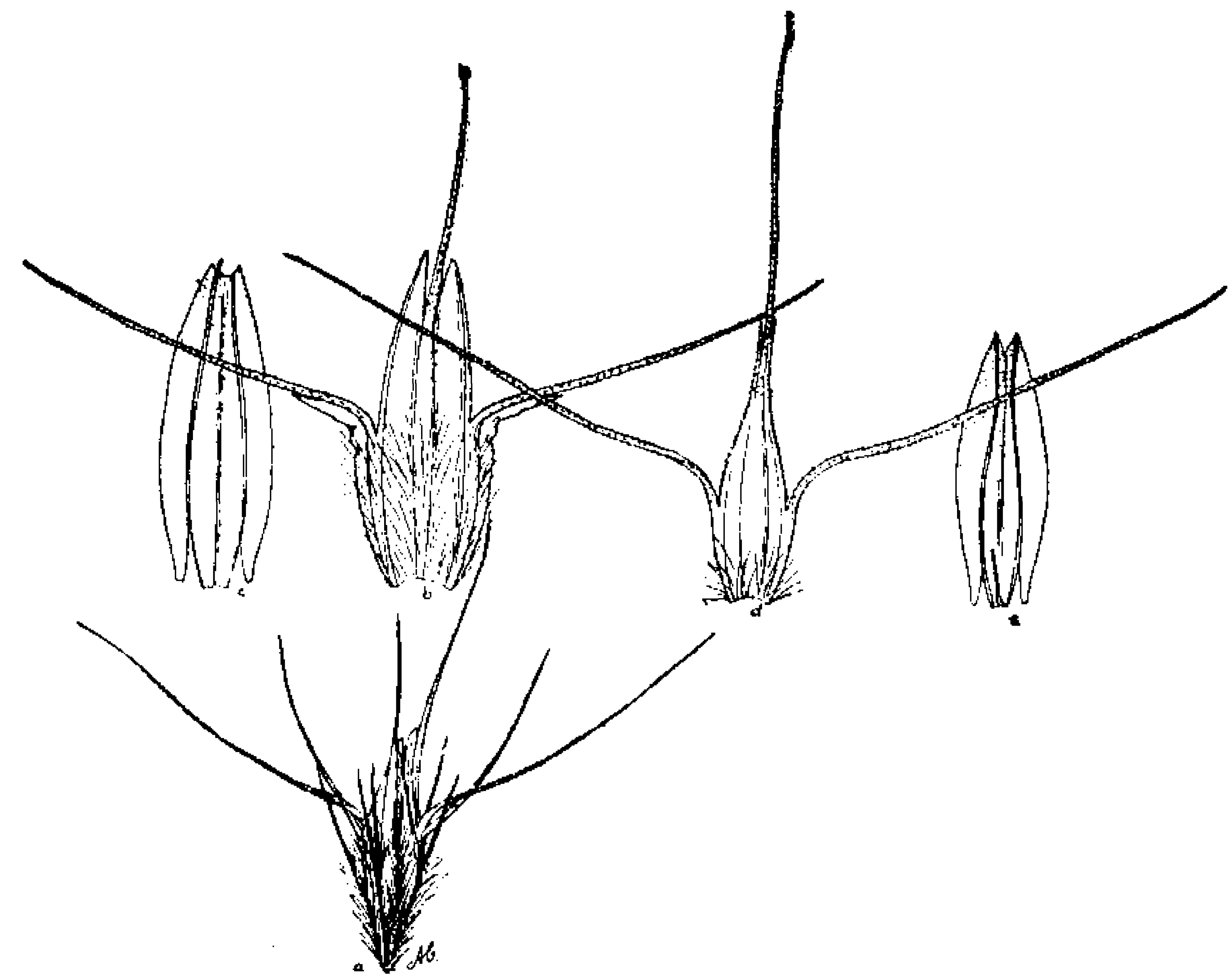

Fio. 20.-Pentarthophis scabra. $a$, Spike; $b, c$, lemma and palet of first floret; $d$, e, lemma and palet of second floret, a, Scale 5; b-e, scale 10. From Heyde \& Lux 4659.

hairs; blades mostly radical, rather harsh, riyid, very slightly seabrous on the margin. the lower 4 to $5 \mathrm{~cm}$. long, the upper reduced to $2 \mathrm{~cm}$. long or less; panicle racemose, loose, 4 to $5 \mathrm{~cm}$. long, the rach is zigzag; spikes about 12 , small, $8 \mathrm{~mm}$. long, including the awns, consisting of one perfect, 2-fowered spikelet and a rluster of awns below; cluster of awns consisting of 5 parts, 2 of these united below, representing the continuation of the rachis, one slightly expanded, representing the first glume of the perfect spikelet, the other two representing the aborted lower spikelet, all of these, together with the upper glume densely white-hairy; lemma of the firat floret, including awns, about $6 \mathrm{~mm}$. long and of the second floret abont $7 \mathrm{~mm}$. long, both sparingly hairy, the upper coriaceous; palet slightly scabrous on the nerves, convolute, nearly $3 \mathrm{~mm}$. long, scarcely awned; caryopsis not seen. (FIGURE 20.)

a This is from tropical America instead of the Island of Luzon, at stated by Prest. See Merrill's opinion in the Philippine Journal of Science (1:380. 1906). 
HERBARIUM SPECIMENS.

Mexico: Nelson 2940, Chiapas.

Guatemala: Heyde \& Lux 423, Santa Rosa.

\section{Pentarrhaphis polymorpha (Foum.).}

Atheropogon polymorphus Fourn. Mex. Pl. 2: 141. 1881. A few spikes of the type before me identify this plant perfectly. Fournier had smaller plants, however, than any in the U. S. National Herbarium, as indicated by a photograph of the specimens in the herbarium of the Muséum at Paris.

Bouteloua fourneriana Vasey; Wats. Proc. Amer. Acad. 22: 461. 1887. A name only.

Pentarrhaphis fourneriana Hack. \& Scribn. Bull. Torrey (lub 17: 229, pl. 107, 108. 1890. Pringle's no. 2559 in U. S. National Jerbarium jo a duplicate of the type.

Pentarrhaphis geminata Hark. \& Scribn. Bull. Torrey Club 17:230. 1890. A name only.

DESCRIPTION .

An erect, smooth, cespitose peronnial, about $30 \mathrm{~cm}$. ligh, with the habit of welldeveloped plants of $B$. trinii, but larger thrughont; culms mostly erect, but in some

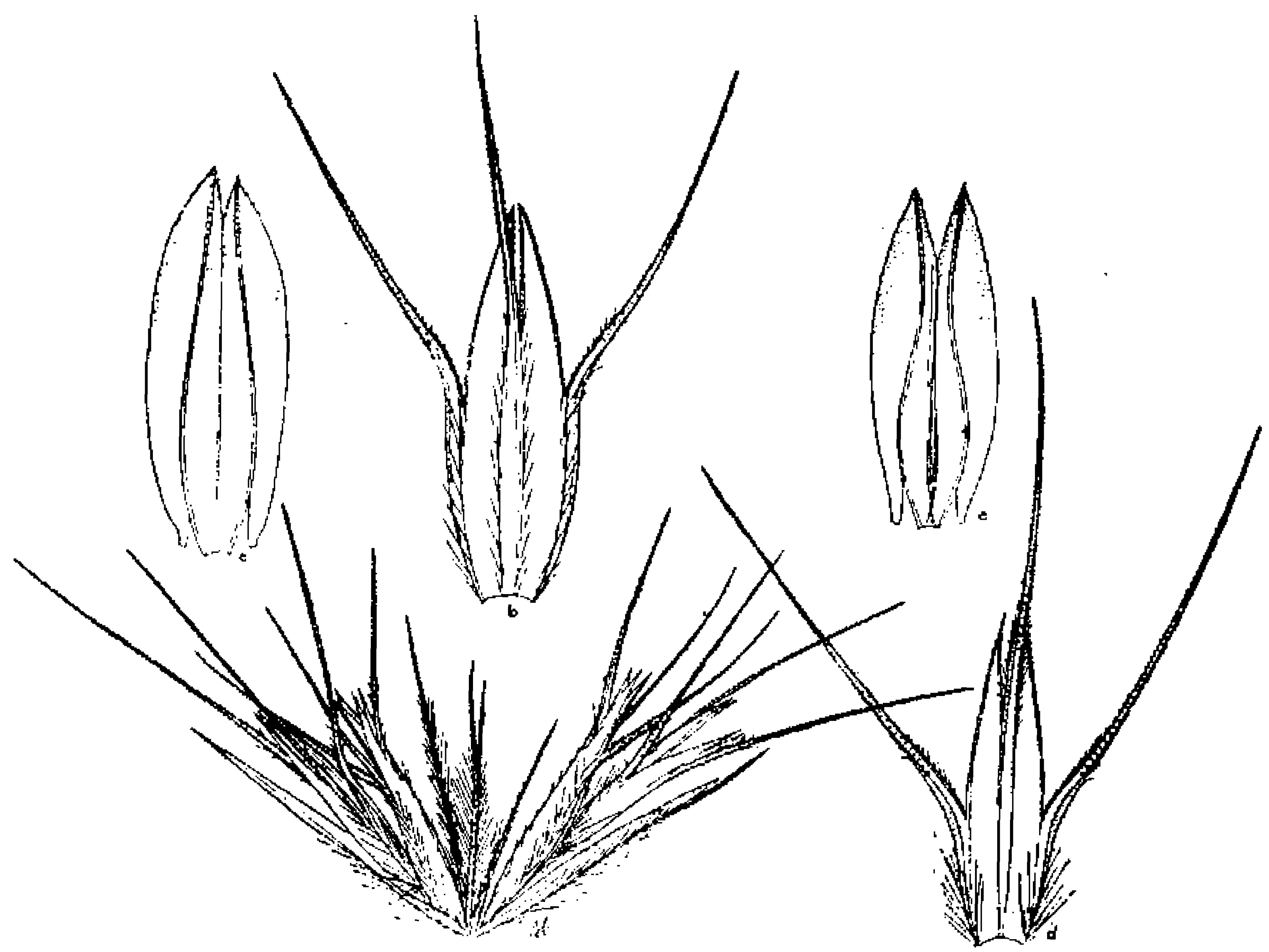

FIa. 21.--P'ntarrhaphis polymorpha. $a$, Spike displayed; $b, c$ lemma and palet of first floret; $d, e$, lemma and jalet of second floret. $a$, Scale 5 ; $b-e$, seale $7 . j$. From Pringle 2559.

specimens inclined to be slightly geniculate; upper blades sparse, flat, and short, the lower more abundant and longer, 5 to $10 \mathrm{~cm}$. long and about $1 \mathrm{~mm}$. wide, bearing a few minute, acaltered hairs on both surfinces; sheaths striate, smooth, narrow, the figule reduced to a ciliate fringe; panicle racemose, the rachis wavy or zigzag; spikes 4 to 8, triangular, 6 to $10 \mathrm{~mm}$. long, purplith in all the specimens at hand; spikelets with backs together, 2-flowered, the lower floret pistillate, the upper staminate, witl a bifid or undivided awn-like rudiment of a third; glumes narrow, the lower reduced to little more than an awn about $4 \mathrm{mmm}$. lom, the upper wider, keeled, notched above, 5 to $6 \mathrm{~mm}$. long; lemma 5 to $6 \mathrm{~mm}$. long, including the 3 nearly equal awns, the glumes and lower lemma covered with white hairs $1 \mathrm{~mm}$. long; palet 3 to $4 \mathrm{~mm}$. long, deeply 
cleft and bearing 2 short awns; palet and upper floret smooth; behind the palet of the upper floret, a short awn, $1 \mathrm{~mm}$. long, the prolongation of the rachilla; caryopsis not seen. (Fioure 21.)

The species has not often been collected. In the U. S. National Herbarium, Pringle 2559, 11242, 5398, and Palmer 200, all from the State of Jalisco, Mexico, are representative. Palmer has also collected it near Durango, Mexico. Rose's no. 1621, Sinaloa, and Rose $\&$ Iough 4775 , Jalisco, are typical.

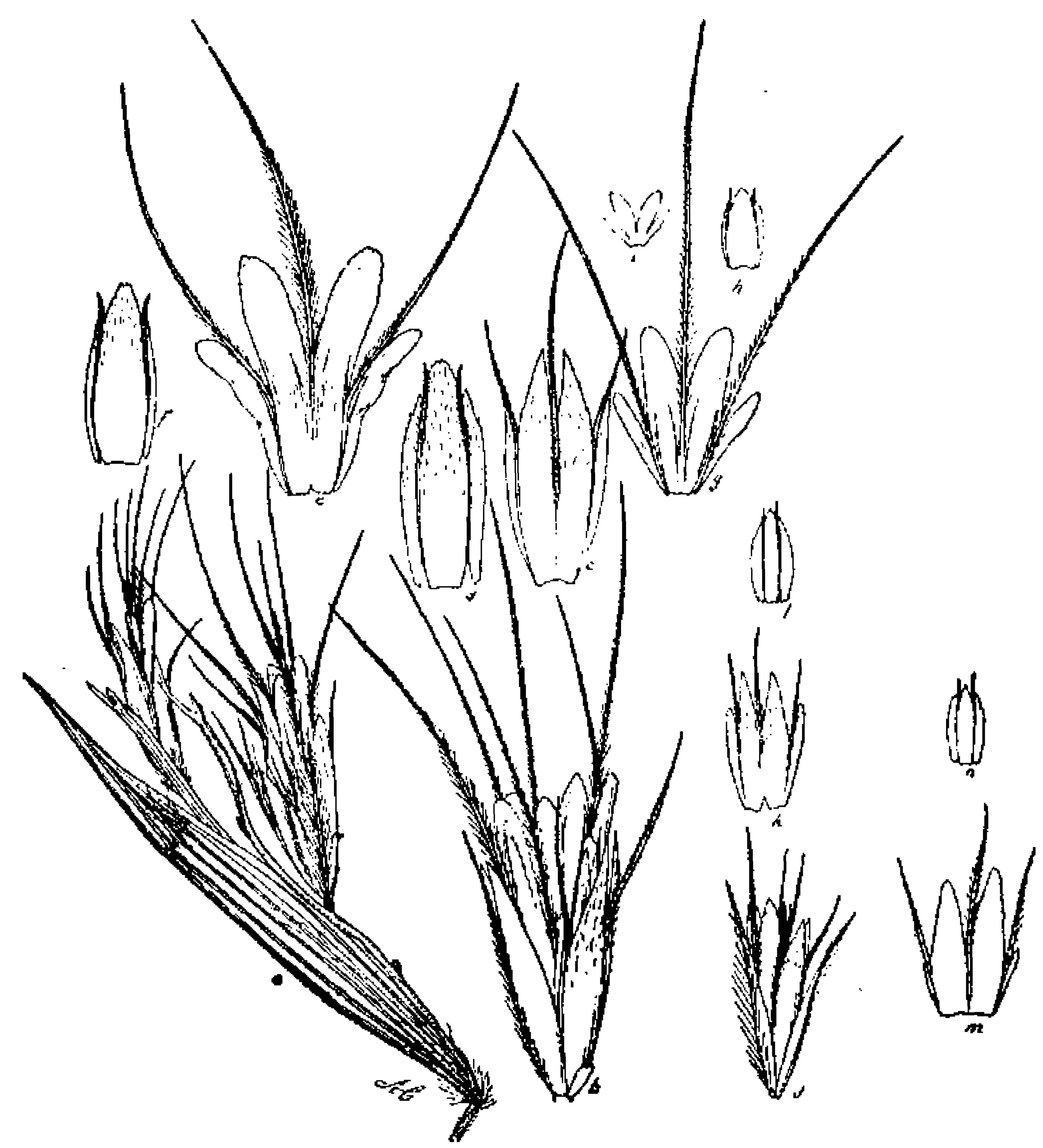

FiG. 22,-Cathestecum prostratum. a, Sheath with inflorescence protruding, showing two splkes, one with 3 spikelets, the other with the lower pair of spikelets aborted; $b$, uppermost spikelet; $c, d$, lemma and palet of irst floret; $c, f$, lemma and palet of second floret; $\theta, h$, lemma and palet of third floret; $i$, lemma of fourth floret; $j$, one of lower pair of spikelets; $k, l$, lemnia and palet of first floret; $m$, $n$, lemma and palet of second floret. $a$, Bcale $5 ; b-n$, scale 7.5 . Fr m type specimen.

\section{Cathestecum Presl.}

Calhestecum Presl, Rel. Haenk. 1: 294. pl. 4\%. 1830. Based upm C. prostratum. Bentham and Hooker a write the name "Cathestechum."

Inflorescence racemose, with 4 to many spikes, each consisting of 3 appruximate spikelets, the first glume of each spikelet, or at least of the terminal one, more or less reduced, commonly to a nerveless fimbriate sciale, the lemmas of the upper florets showing a tendency toward branching, or sometimes an actual multiplication of nerves and awns by division of the typical lateral nerves. 


\section{Cathestecum prostratum Presl.}

Cathestecum prostratum Pres1, Rel. Haenk. 1 : 295. pl. 42. 1830; Steud. Syn. Pl. Glum. 1 : 201. 1854; Fourn. Mex. PI. 2 : 133. 1881; Hemsl. Biol. Centr. Amer. Bot. 3: 517. 1885. The following set of characters is drawn from a panicle of the type before me: Spikes 4 in 6 , small, about $2.5 \mathrm{~mm}$. wide and $4 \mathrm{~mm}$. long, or, including the awns of the upper spikelets, $8 \mathrm{~mm}$. long, the rachis prolonged into a bifid awn $2 \mathrm{~mm}$. long, the lower pair of spikelets always aborted and often reduced to little more than the glumes, always short-awned; third spikelet, 2-flowered, with a rudimentary third floret, the first floret pistillate; glumes narrow, awned, densely hairy, the first one of the third foret reduced to a blunt, comparatively wide, nerveless scale less than $1 \mathrm{~mm}$. in length; lemma of third spikelet about $4 \mathrm{~mm}$. long, including the slightly unequal awns, slightly hairy above, with subulate acute lobes; palet

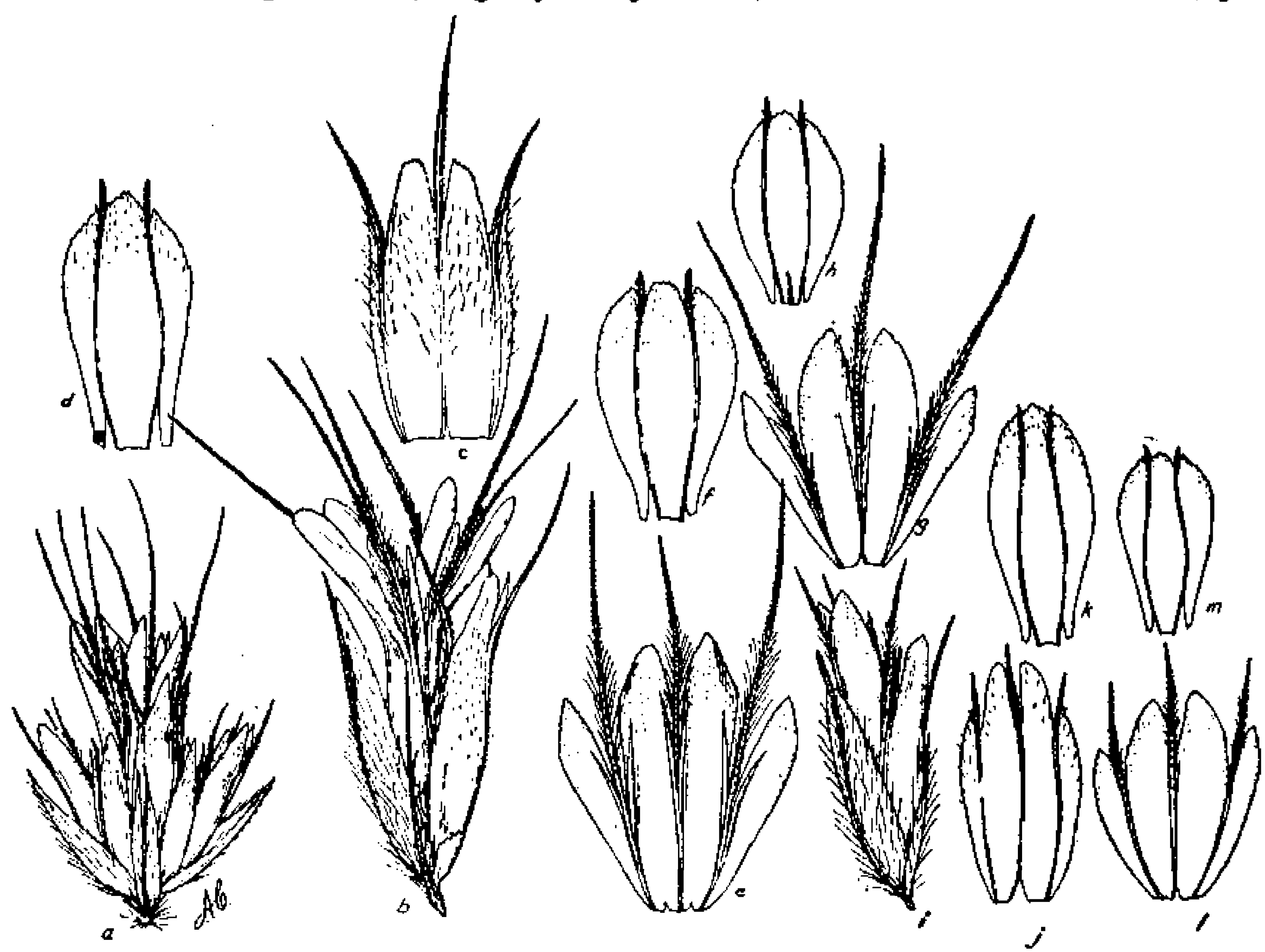

Fic. 23.-Cuthestecum prostratum. a, Spike; $b$, uppermost spikelet and prolongation of rachis; $c, d$, lomms and palet of first floret; $e, f$, lemma and palet of second floret; $g, h$, lemma and palet of third floret with prolongation of rachilla attached; $i$, one of lower pair of splkelets; $j, k$, lemms and palet of first floret; $l, m$, lemms and palet of second floret. $a$, Scale 5; $b-m$, scale 7.5. From Pringle 8707.

2-nerved, with edges incurved, scarcely awned; lemmas of second floret and rudiment of third, with longer, more prominently hirsute awns and rounded, very deeply divided lobes.

\section{DESCRIPTION ,}

A tuited annual, about $20 \mathrm{~cm}$. high; culms variable, erect, geniculate or halfprostrate, branching at the nodes; sheaths loosely inclosing the main culm and its branches, the ligule reduced to a delicate fringe of flexuous, white hairs; blades few, short, 3 to $5 \mathrm{~cm}$. long, $1.5 \mathrm{~mm}$. wide, the upper subulate, about $1 \mathrm{~cm}$. Iong; panicle loosely racemose, with a zigzag flattened axis about $3 \mathrm{~cm}$. long; spikes 4 to 8 , triangular rhomboidal, about $8 \mathrm{~mm}$. long; lower or lateral spikelets about $4 \mathrm{~mm}$. long, the central or upper one about $6 \mathrm{~mm}$. long, the two lateral 2-flowered and apparently both always staminate, the upper central spikelet consisting of one lower pistillate and two upper staminate florets and a club-shaped or bifurcated prolongation of the rachilla, about $1 \mathrm{~mm}$. long, behind the palet of the third floret; second glume of each 
opikelet deusely covered with longr straight hairs, that of dach litteral spikelet about $3 \mathrm{~mm}$. and of the upper one about $4 \mathrm{~mm}$. Iong, the first grlume of atath litoral spikelet less hairy and only $2 \mathrm{~mm}$. long, that of the upper spikelet reducon to al broik fanshaped, nerveless scale scarcely $1 \mathrm{~mm}$. in length; lemmas of the lower spikelets eparsely short-hairy, coriaceous, 2 to $3 \mathrm{~mm}$. long, short-awned; pale1s convolute, 2 nerved, slightly scabrous at the tip, not awned; awns of palet of third spikelet about $2 \mathrm{~mm}$. long and more scabrous, the parts of the third floret much reduecel; caryopsis not seen. (FIGUREs 22, 23.)

The above description is drawn from Pringle's no s707, upon whicls the lirge spikes are by far the most abundant, but upon the same specimens there are ofler spikes whicl are the eame as those of the type.

The Haenke specimen is uniform in having small spikes with the lateral spikelets more or less aborted. The Pringle speximen, on the contrary, shows the species to be dimorplici.

Foumier refers one of Schatiner's specinens without locality to this spere ies, bull 1 have seen only the fragment of the type mentioned above and Iringle $8: 00^{-}$, collected

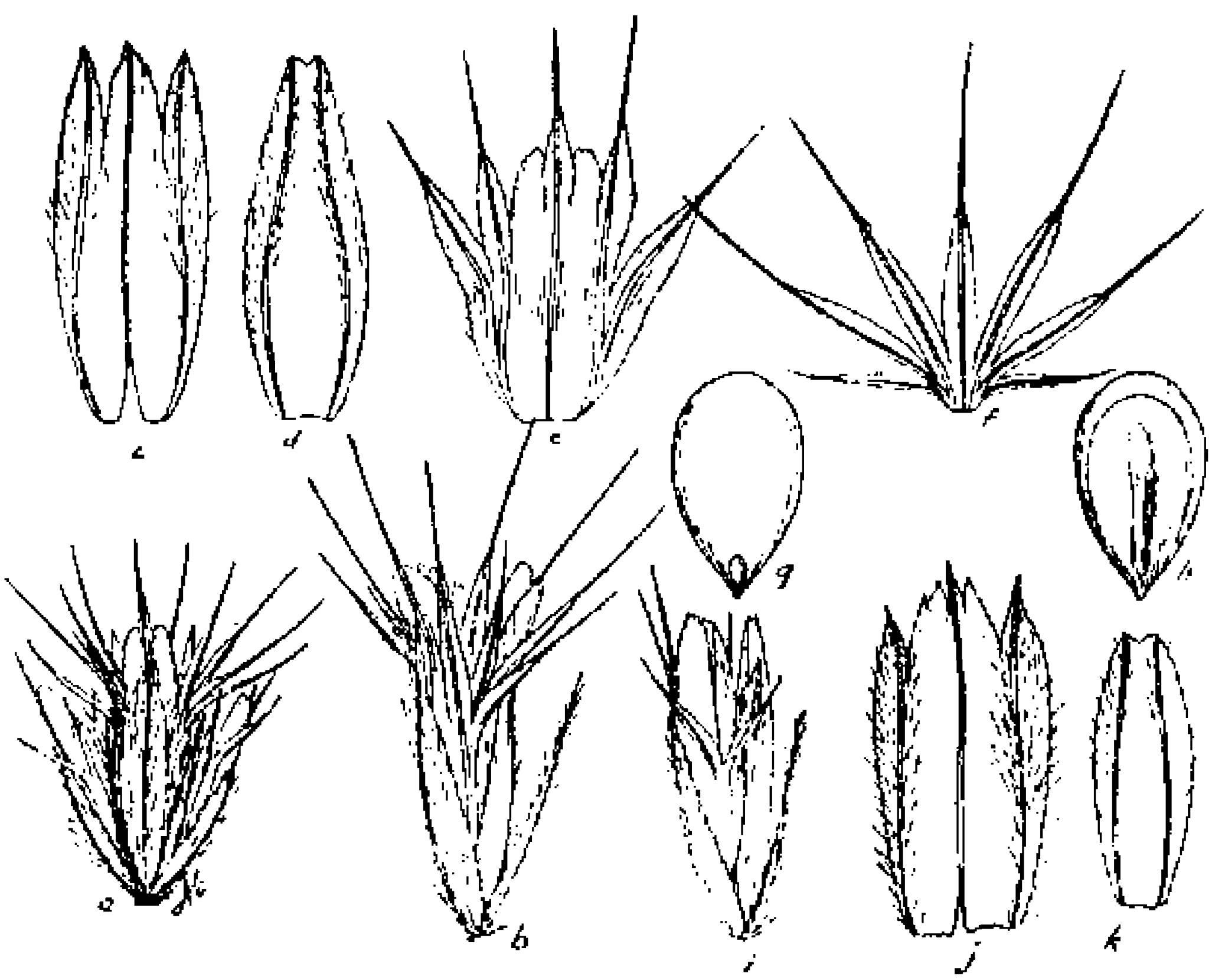

Fia. 24.--Cathestecum multifidum. a, Splke; $b$, uppermost spikelet; $c, d$. lemms and palet of first lloret; $e, f$, lemmes of second and third florets: $g, h$, two views of earyopsis; $i$, one of lower ptir of spikelets; $j, k$, lemma and palet of lower floret. $a$, Scale $5 ; b-f$, scale $7.5 ; g-i$, scale $10 ; j, k$, seale 7.5. From type speciunell.

narrow, 10 to $15 \mathrm{~cm}$, long, a trifle nver $1 \mathrm{~mm}$, wide, the upper reduced, thinly becet with long, straight or flexuous, white hairs, 2 to $3 \mathrm{~mm}$. long, arising from papillis; panicle racemose, 5 to $6 \mathrm{~cm}$. Iong, on at zigzacr ixis; spikes about 15 , small, 4 to $5 \mathrm{~mm}$. long over all, roughly triangular in outline, the mohis prolonged at a barbed, mimple or bitid awn, usually loss than $2 \mathrm{~mm}$. long, with or withont a very small winged expansi:m on one side; lateral spikelets 2-fowered, the rachilla prolonged into a blunt or bificl awn behind the palet of the second floret, or often the uppor floret aborted and reduend to a bunch of awms upon a naked stipe; central nikelet 2 flowered, with a well-kew. oped third floret consisting of 6 to 10 expanded awns on at naked stipe; grlumes pulx cent, narrow, acuminate or short-awned, the first about $2 \mathrm{~mm}$. longr, the upleer about $3 \mathrm{~mm}$. long; lemma of the lower furet about $2.5 \mathrm{~mm}$. long over all, bearing a few suattered hairs, 3-nerved, 3-itwed, the awns very short; palet plicate, about $2.5 \mathrm{~mm}$. long, icarecly awned; lemma of the second floret becoming 5 to $i$-awned by the splituing of ealu of the normal lateral nerves into 2 or 3,3 to $5 \mathrm{~mm}$. long; lower foret of upper sijikelet apparently pistillate only, the others staminate; caryopwis not seen. (lictire: 24 .)

The type of this species was collected by myself at Iguala, Mexico, Scplember 9, 1909. It was later collected at Onxaca, Mexico, by Hitchcock (no. 6164). It is an 
abundant and conspicuous plant, easily recognized by its long, delicate, graceful culms, small spikes, tufted habit and narrow, flat, hairy, abundant leafage. In minuter details it differs from all other apecies of the genus in having the lateral awne of the lemmas of the second floret split into 2, making a well-developed 5-awned lemma, while the lower florets are typically 3-awned, and the lateral awns of the lemma of the third floret and rarely of the second also are split into 3 , making it 7 -awned and 7-nerved.

It is very probable that this characterization will have to be modified when mature material becomes available, for the above collections are of plants in bloom only.

\section{Cathestecum erectum Vasey \& Hack.}

Cathestecum erectum Vasey \& Hack. Bull. Torrey Club $11: 37 . p l .45 .1884$. The Havard specimens from Presidio County, western Texas, no. 30, 1881, and no. 2, 1883, are in the U.S. National Herbarium, together with the Palmer specimen from Sonora, Mexico, 1869, which is the first mentioned. There is a note on Havard's no. 30 in
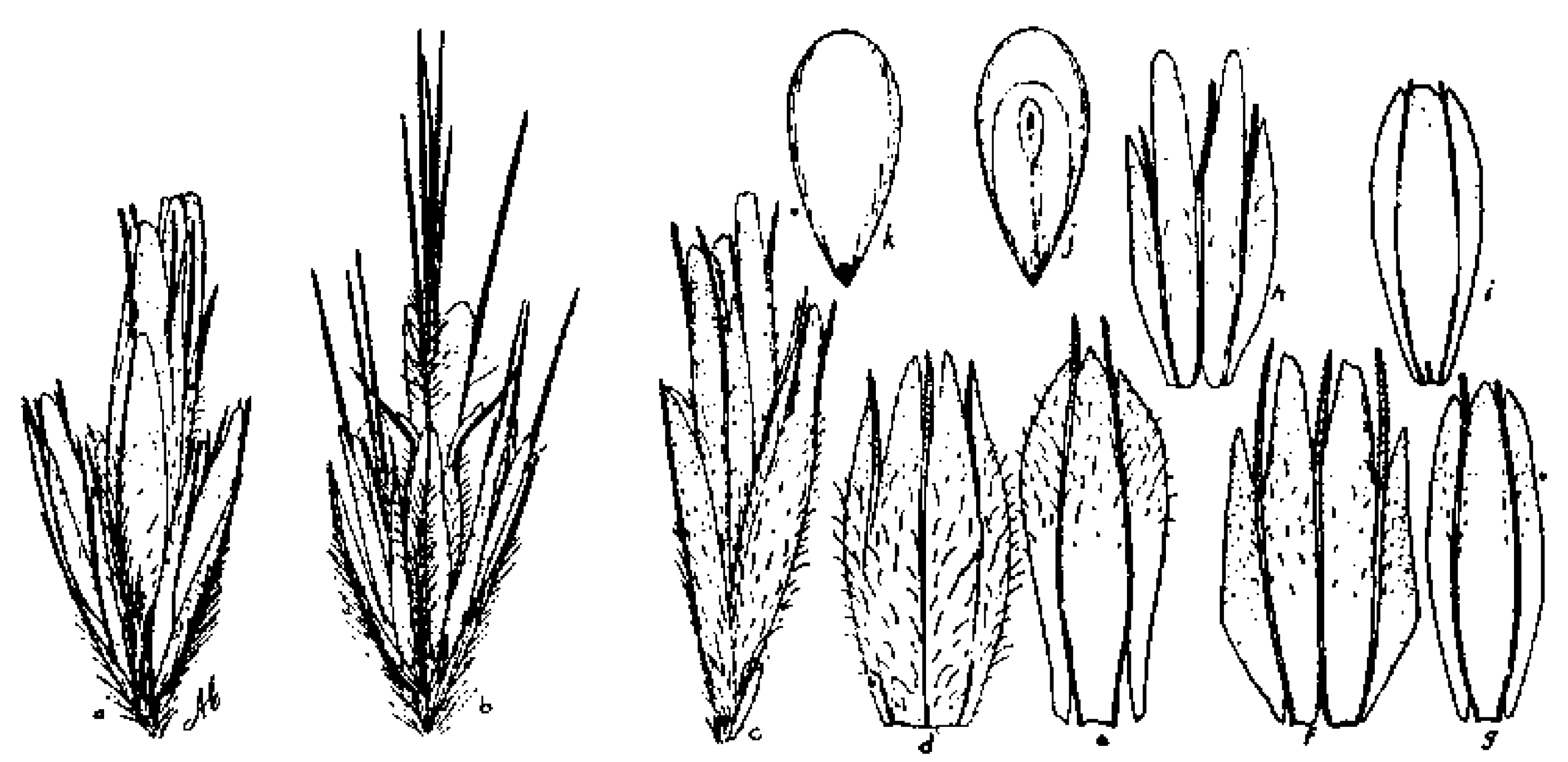

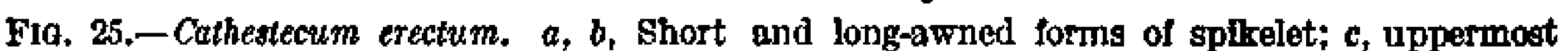
splkelet of $a ; d, e$, lemma and palet of first floret; $f, \theta$, lemma and palet of second floret; $h, i$, temma and palet of third foret; $j, k$, two views of caryopsis. $a, b$, Seale $5 ; c-i$, scale $7.5 ; f, k$, seale 10. From Griffihs 6834.

Vasey's hand, "=17 Jr. Palmer 1869." See also T. S. Dept. Agr. Jiv. Bot. Bull. $12^{1}$ : $p l .13 .1890$; Contr. Nat. Herb. 2 : 536. 1894.

This is the species described and figured "by Scribner under the name Cathesterum prostratum Presl.

\section{DESCRIPTION.}

A sparsely hairy, erect, atoloniferous perennial of variable habit, 5 to $40 \mathrm{~cm}$. high; culms erect or geniculate and rooting at the prominently hairy nodes, simple or branched; sheaths sparsely hairy, the ligule a line of long white hairs; blades flat, very variable, abundant below, shortened upward, bearing a few scattered hairs like those on the sheaths, scabrous-margined; panicle racemose, 3 to $5 \mathrm{~cm}$. long, the apex of the axis minutely bifurcated; spikes 6 to 8 , about $8 \mathrm{~mm}$. long, rather thin, but not especially lax; the upper spikelet perfect, the lateral pair rudimentary; lower florets of the lateral spikelets with well developed but sterile lemmas; second floret staminate or neuter, the upper rudimentary; first glume of each spikelet reduced to a short, truncate, nerveless scale, the second long, lanceolate, keeled, hairy, mucronate, 3 to $4 \mathrm{~mm}$. long; lemma coriaceous, smooth, with awns and lobes about equal, but the awns slightly longer, in the upper florets the lobes deeper and the awns with long hairs below; palet slightly shorter than the fertile lemma, plicate, short-awned; caryopsis obovate, $1.5 \mathrm{~mm}$. long, flattened, the scutellum covering about three-fourths the ventral surface. (Figure 25.) 
The above characterization is drawn from the short-awned form which corresponds with the type.

This species is variable. Hitchcock's no. 6776 from Balsas, Mexico, is very different in color, especially from the northern Sonora plants.

In 1904 between Imuris and Santa Ana in the State of Sonora I collected under no 6834 two more or less distinct forms. One, which grew in a favorable depression, is tall and rank, with abundant leafage, and is short-awned. The other, which grew on a conliguous gravelly knoll, shows both short and long-awned forms, but on weparate plants.

Collections have commonly included both forms under the same number. But one thing is peculiar-the two forms are seldom found on the same plant. Both forms produce seed and in exactly the same relative position. Pringle's no. 4559 contains both forms, but the long-awned one has the spikes greatly reduced, the two lower spikelets being very much aborted. Palmer's nos. 1261 of 1891 and 705 of 1890 show both forms also. Not until Hitcheock's 1910 collections from Mexico came in were the two forms found on the same plant. This does not appear to be a case of lengthening of the awn after anthesis, as with Bouteloua chondrosioides, but a true dimorphic character. The species is distributed from the Rio Grunde region of western Texats to Arizona and southward to the state of Colima.

Palmer's no. 345 of 1887 from Guaymas, Mexico, has a liabit which is unique. The culms instead of being geniculate-stoloniferous are erect-proliferous with the same knotly appealance at the nodes, but perfectly erect and not rooting.

\section{HERBARIUM SPECIMENG.}

Texas: Havard 30, and 2, El Paso to Presidio. Nealley, Chenata.

Mvxico: Palmer 18, Yaqui River, Sonora; 345, 161, Guaymas; 66, Chihuahua; 270, Guadalajara; 126, 112, Colima; 705, Alamos; 1460, 1459, Ymala. Pringle 597, Altar; 4559, Tequila. Ilitchcoch 3528, Llano. Brandegee 1, 2, Culiacan.

\section{Cathestecum stoloniferum (l'ourn.).}

Atheropogon stolonifer Fuurn. Mex. Pl. 2: 140. 1881. The type is Liebmann 588, "La Parada, Sierra de Oajaca." As this specimen has not been examined, the description and cited locality are our only guide. The name is appropriate and the description fits the plants referred here. Fournier's characterization of spike detailis, however, is not su siltisfinctory.

\section{DESCHIPTION.}

A low, reeping, stoloniforous perennial, 10 to $15 \mathrm{~cm}$. high, forming at times a moderale turi; culms erect or geniculate, 10 to $15 \mathrm{~cm}$. high, with stolons rooting readily and bearing small tufts of leaves at intervals of $8 \mathrm{to} 10 \mathrm{~cm}$; sheaths short, striate, smooth, the nodes smooth except when geniculate and then hairy, the ligule consisting of a few, long, white hairs; spikes 4 to 6 , triangular in general outline and about $13 \mathrm{~mm}$. long; first floret pistillate, the second staminate, with or without one or two rudimentary additional onee, the latter always more numerous and better developed in the upper central spikelet; glumes of lower spikelets densely hairy, narrow, keeled, acuminate, short-awned, the lower more than $2 \mathrm{~mm}$., the upper more than $4 \mathrm{~mm}$. long, the lower glume of the upper spikelet reduced to a nerveless fan-shaped, fimbriate scale scarcely $1 \mathrm{~mm}$. long; lemma of the lower floret corilceous, pubescent, about $6 \mathrm{~mm}$. long including the awns; central awn about $2 \mathrm{~mm}$. louger than the lateral; lateral awns of the lower spikelets often unequal in the second thoret, 
the third floret when present bearing equal awns, the lemma being very deeply lobed and cut, the lateral awns appearing almost separated; palet plicate, very shortly 2-awned; caryopsis obovate, 1.5 to $2 \mathrm{~mm}$. Iong, with conspicuous embryo and scutellum covering practically the entire ventral surface. (Fiaure 26.)

The species is very abundant in the canyon of Tomellfn, where it constitutes the main pasturage over extensive areas and whence it extends to the valley of Oaxaca. It makes a semblance of a turf in places and in habit very closely resembles Hilaria cenchroides.

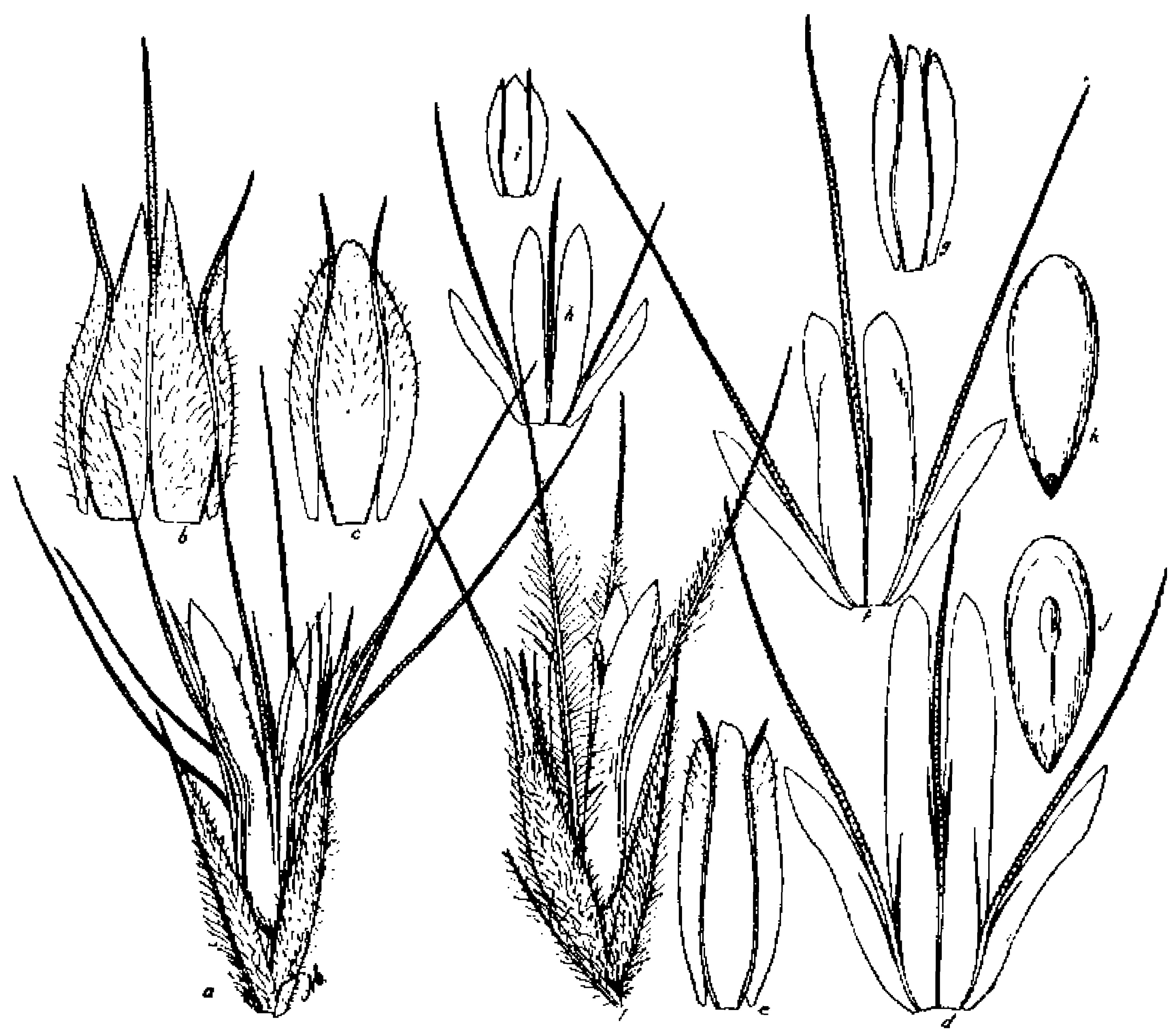

FIG. 26,-Cuthestaum stoloniforum. a, Uppermost splkelet; b, c, lemma and palet of first floret; $d, c$, lemma and palet of second floret; $f, a$, lemma and palet of third floret; $h, i$, lemma and palet of fourth floret; $j, k$, two views of caryopsis; $l$, one of lower pair of spikelets. $a-i$, Scale $7.5 ; j, k$, scale $10 ; l$, scale 7.5 . From Griffith 8122 .

The only specimen referred here, aside from collections by myself and Hitchcock listed elsewhere, $a$ is no. 958, collected by C. L. Smith at San Antonio, valley of Oaxaca, Mexico.

\section{BoUtTELOUA Lag.}

Botelua Lag. Var. Cienc. $2^{4}: 134.1805$. Based upon $B$. racemosa.

Atheropogon Muhl.; Willd. Sp. P1. 4: 937. 1806. Based upon A. apludioides.

Triathera Desv. Nouv. Bull. Soc. Philom. Paris 2 : 188. 1810. Based on Aristida americana.

Heterosteca Desv. Nouv, Bull. Soc. Philom. Paris 2 : 188. 1810. Based upon $H$. juncifolia from "Antillis," See also H. B, K. Nov, Gen. \& Sp. 1: 173. pl. 54. 1816. The name is written by Kunth $b$ "Heteroatega," and by Hooker c "Heterostegon." 
Chondrosium Desv. Nouv. Bull. Soc. Philom. Paris 2: 188. 1810. Based upon Chloris procumbens Durand.

Actinochloa Willd.; Beauv. Ess. Agrost. 41. 1812. "A. tonuis Willd. manu*cript" mentioned as a synonym of Chondrosium. See also Roem. \& Schult. Syst. Veg. 2: 417. 1817. Based upon Chondrosium procumbens Desv.

Dineba Beauv. Ess. Agrost. 98. 1812. In listing the genera in which the species of his proposed genus have been placed Beanvois gives after "Dineba Dellu.," Aristida first and without doubt had in mind $A$, americana $\mathrm{J}$. In listing the species he places "D. arabica (Cynosurus retroflexus ? Lin.)" first and "Aristida americana Lin.," following. In his illustrations he gives $D$. curtipendula first, followed by $D$. arabica and $D$. americana. Delile a figures under $D$. aegyptiaca the same plant as does Beauvois under $D$. arabica. But this species does not belong to this group. (See list of excluded names, p. 423.)

Polyodon IT. B. K. Nov. Gen. \& Sp. $1: 174 . p l .55 .1816$. This is a monntypic genus based upon $I$. distichum.

Eutriana Trin. Fund. Agrost. 161. 1820. Based upon Chloris curtipendula Michx.

Aristidium (Endl.) Lindl. Veg. Kingd. 116. 1846. Futrina, section A ristidium Endl., b based on Dinebra aristidoides H. B. K. (misspelled "aristnides"), js listed as a genus by Lindley.

Triplathera (Endl.) Lindl. Veg. Kingd. 116. 1846. Eutriana, eertion Triplathera Endl, $c$ based on Eutriana multiseta, is listed as a genus by Lindley.

Antichloa Sweet; Steud. Nom. Bot.ed. 2. 1:108.1840. The Eame an "Aclinochloa"; a name only.

Nestlera Willd.; Steud. Nom. Bot. ed. 2. 2: 192. 1841. Based upon N. frsturacformis of Willdenow Ilerbarium, which is Bouteloua bromoides, i. e., B. radirosa, areord ing to the Index Kewensin; names only.

Erucaria Cervantes, La Naturaleza (Mexico) 347. 1870. (See list of excluded names, p. 424.)

"Chondrosia or Chondrosium 1)esv.;" Benth. Journ. Linu. Soc. 13u1. 19: 104. 1881. Simply a discussion of the general divisions of the griup and a mentinn of Bouteloua racemosa Iagr. as the best-known speries.

Very variable in every detail; spikes one 1060 ; spikelets more than $3, d$ pertinate or not, 2 to several-flowered, mostly 1-flowered, with one or more rudiments; the lemmas 3-nerved, 3-awned, the palei: 2-nerved, 2-awnerl.

\section{Bouteloua procumbens (1) rand).}

Chloris procumbers Durand, Chlor. Sp. 1808. I am able to verify the opinions of some of the older authors from a copy of the original deweription kindly furnished by the Director of the Kew Gardens.

Chondrosium procumbens Desv. in Beauv. Ess. Agrost. 41. pl. 9.f. 7. 1812. Bawed on "Chloridis spec. Durand." Desvatux $e$ also gives this, the only ppecies, under his genus Chondrosium, with Chloris promumbens Durand at a synonym.

Atheropogon procumbens Jaeq. Eclog. Gram, 16. pl. 12. 1813. ('opy in Gray Herbarium.) The illustrations and description are geod. Chloris prommbers Durand is ciled as a synonym.

Bouteloua prostrata Lay. Gen. \& Sp. Nov. 5. 1816. A npecimen from Laghasea in the herbarium at Munich appears to belong here, but the single culm before me bas two rpikes, which is the unusual form of the species. Iagasca listed this specios

a Descr. Egypte 26. pl. 11.f. \$. 1813.

$b$ Gen. P1. 94. 1836.

c Trans. Linn. Soc. Bot. 20: 175. 1847.

d An exception is found in $B$. uniflora which has one spikelet in a spike.

$e$ Journ. de Bot. $1: 69.1813$. 
without. dezcription in an earlier ${ }^{a}$ paper. See also U. S. Dept. Agr. Div. Bot. Bull. $12^{1}: p l .42 .1890$.

Chondrosium tenue Willd.; Beauv. Ess. Agrost. 158. 1812. Beauvois publishes "Actinochloa tenuis Willd. mss." on page 41 and makes the above combination in his index on page 158. He, however, gives no description. In his private copy of the "hove-cited work he has written " = Bouteloua simplex Lag. and Actinochloa, Roemer." See also H. B. K. Nov. Gen. \& Sp. 1:176. pl. 57. 1816. Plainly distinguishable by the figure and description.

Actinochloa procumbens Roem. \& Schult. Syst. Veg. 2:417. 1817. Based upon Chloris procumbens.

Actinochloa tenuis Willd.; Roem. \& Schult. Syst. Veg. 2 : 418, 1817. Chondrosium tenue $\mathrm{II} . \mathrm{B} . \mathrm{K}$. is cited as a synonym.

Actinochloa prostrata Roem. \& Schult. Syst. Veg. 2:419. 1817. IBased upun Bouleloua prostrata.

Eutriana tenuis Trin. Gram. Unifl. 240. 1824. Jased upon Actinochloa tenuis Willd. Chloris filformis Poir.; Kunth, Rév. Gram. 1 : 93. 1829. Mentioned as a synonym of Chondrosium tenue.

Chloris tenuis Poir.; Kunth, Rév. Gram. 1 : 93. 1829. A herbarium name cited as synonym of Chondrosium tenue.

Chondrosium? prostratum Kunth, Rév. Gram. 1 : 94. 1829. Basod upon Bouteloua prostrata Lag. See also Sweet. IIort. Brit. 1 : 455. 1826; Fourn. Mex. Pl. 2 : 138. 1881.

Bouteloua tenuis Griseb. Abh. Ges. Wiss. Göttingen 19:211. 1874. (Plantae Lorentzianae.) Based upon Chondrosium tenue.

Boutcloua pusilla Vasey, Bull. Torrey Club $11: 6.1884$. The type, in the National Iferbarium, was collected by Vasey at Kingman, New Mexico, June, 1881.

\section{DESCRIPTION.}

A small, smooth, cespitose, prostrate or ascending, sparingly branched, annual, atfaining its best development above an altitude of 1,600 meters; sheaths smooth, striate, with reduced, shortly pubescent ligules and few narrow blades only 2 to $3 \mathrm{~cm}$. long; spikes solitary, 1.5 to $2 \mathrm{~cm}$. long, revolute toward maturity, fertile to the end of the rachis; spikelets consisting of one lower fertile floret and an upper rudinent; glumes keeled, acuminate, pointed but awnless, the first smonth, about $3 \mathrm{~mm}$. Iong, the second minutely hispid on the keel and 4 to $5 \mathrm{~mm}$. Inng; lemma broadly oval, with 3 hispid, unequal awns, the central the longest and expanded with wing-like projections below; palet broadly obovate, smooth, broadly rounded above, about $3 \mathrm{~mm}$. long, rudiment consisting of 3 equal, hispid awns, about $4 \mathrm{~mm}$. long, together with 2 or 3 very small scales upon a naked stipe bearing a tuft of white hairs at its apex; caryopsis about 2 $\mathrm{mm}$. long, $0.75 \mathrm{~mm}$. wide, obovate, the scutellum covering the entire ventral and curving back over a portion of the dorsal surface. (FIa une 27.)

When thinly distributed, especially upon loose fertile soils, this species forms large bunches which are more likely to be prostrate than when the plants are crowded and smaller.

As a fornge plant it is of very littlo value on account of its diminutive size and the case with which it pulls up when grazed. Indeed, it has never been met with in sufficient abundance to be much of a factor in feed production.

Specimens representing my conception of the species are Pringle 6450, 11218, Palmer 176, 332, 503, 712, Metcalfe 583. Pringle 1434, Chihuahua, and 6450, Federal District of Mexico, and Schaffner 156, San Luis Potosi, approach the heavy-spiked

a Var. Cienc, $2^{4}: 141.1805$. 
form of South America treated as $B$. simplex. Indeed, the last is almost a perfect match for some of the South American forms. The species has a very wide distribution, extending from Colorado southward, its place being taken by $B$. simplcx in

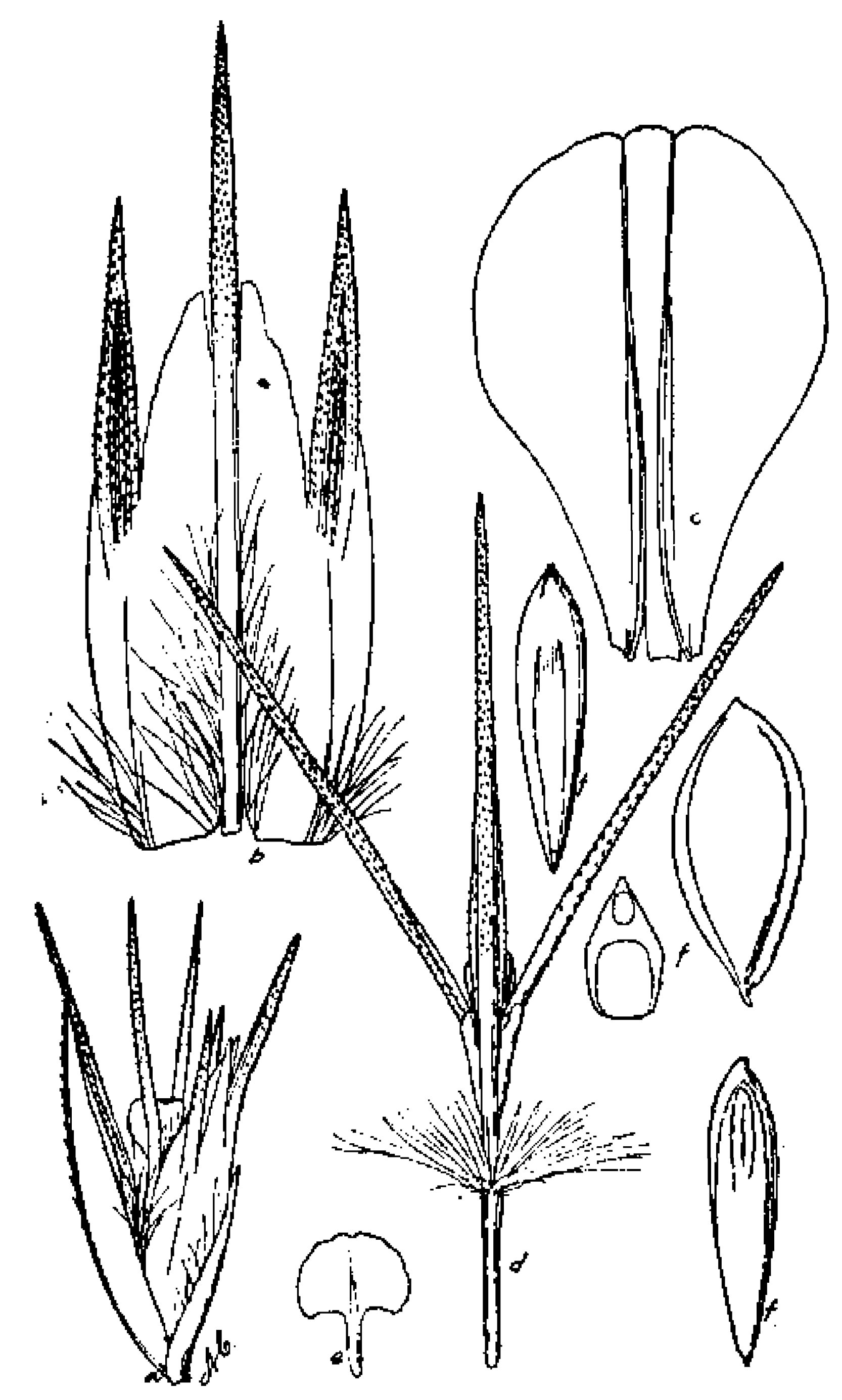

FIG. 27.-Bouteloua procumbens. a, Spikelet; $b, c$, lemma and palet of first floret; $d$, rudiment of second floret; $c$, rudiment of third floret; $f$ three views and cross section of caryopsis. a, sealo $7.5 ; b-f$, scale 12.5. From Griffiths 7362 .
South America, if indeed the latter is distinct.

In South American specimens the spikes are commonly two or more at the end of some culms, this form thus approaching the genus Chloris. This condition is rare in North American specimens, if those examined and collected are typical, but is sometimes found, however, in $B$. procumbens, as shown sparingly by Griffith 9516 , collected in the vicinity of Prescott, Arizona.

\section{HERBARICM SPECIMENS.}

Arizona: Leiberg 5897, San Franciaco Mountains.

Colorado: Chase 2569, South Cheyenne Canyon; 6500, Pikes Peak Region; 5395, llarbert Ranch to Wet Canyon, Spanish Peaks. Shear 1262, Durango. Hitcheock 1771, Manitou.

Maine: Parlin 1514, New Brunswick, introduced in sheep wool.

New MeXICo: Wooton 2925, Encinada. Wooton \& Standley 3523, Lincoln County; 5049, San Miguel County; 212, Lincoln County. Metcalfe 1502, Kingston, 583, Soccoro County. Baker 90 and 163 , Chama. Jones 4348, Grants.

Utan: Jones 5995, Panguitch.

Mexico: Pringle 1434, plains of Guerrero; 6450, Pedregal, Valley of Mexico; 13242, mesas near Zontecomate, IIidalgo; 11218, Federal District. Palmer 3, Chihuahua; 480, Guadalajara; 176, Alvarez; 332, near Saltillo; 397, 398, Saltillo; 712, Durango. Schaffner 1016, 156, San Inis Potosí.

\section{Bouteloua aimplex Lag.}

Bouteloua simplex Lag. Var. Cienc. $2^{4}: 141.1805$. There is a specimen in the herbarium of the Madrid Bolanical Garden named Bouteloua simplex by Lagasca.

Chondrosium humile Beauv. Ess. Agrost. 158. 1812. A name only listed in the index and based on Actinochloa humilis, a manuscript name of Willdenow published without description on page 41; H. B. K. Nov. Gen. \& Sp. $1: 175 . p l .56 .1816$. The figures and description in the last work are sufficient to identify the species.

Actinochloa humilis Willd.; Roem. \& Schult. Syst. Veg. $2 ; 417$. 1817. Based upon Chondrosium humile H. B. K.

Actinochloa simplex Roem. \& Schult. Syst. Veg. 2 : 418. 1817. Based upon Bouteloua simplex Lag. 
Atheropogon humilis Spreng. Syst. Veg. 1:293. 1825. Based upon Chondrosium humile $\mathrm{H}$. B. K.

Eutriana humilis Trin. Gram. Unifl.239. 1824. Based upon Actinochloa humilis Willd. Chondrosium? simplex Kunth, Rév. Gram. 1:94. 1829.

Based upon Bouteloua simplex Lag.

Bouteloua humilis Hieron. Bol. Acad. Cienc. (Córdoba)

4 : 495. 1882. Based upon Chondrosium humile Beauv,

Bouteloua brachyathera Philippi, Anal. Mus. Nac. Chile (Bot.) 8: 85, 1891. The type, no. 287 of Philippi's herbarium, has been examined. $a$

Bouteloua rahmeri Philippi, Anal. Mus. Nac. Chile (Bot.) 8: 85. 1891. Herb. Philippi, no. 268, Province of Terapaca, Chile, is the type. It has been through my hands and I find it a very good match for a specimen in the U. S. National Herbarium collected by Rusby (no. 34) near Yungos; Bolivia, in 1885.

\section{DESCRIPTION,}

A prostrate or ascending, spreading, smooth annual, 20 to $25 \mathrm{~cm}$. high; culms geniculate or ascending, seldom branched; sheaths smooth, deeply striate, rather loose, the

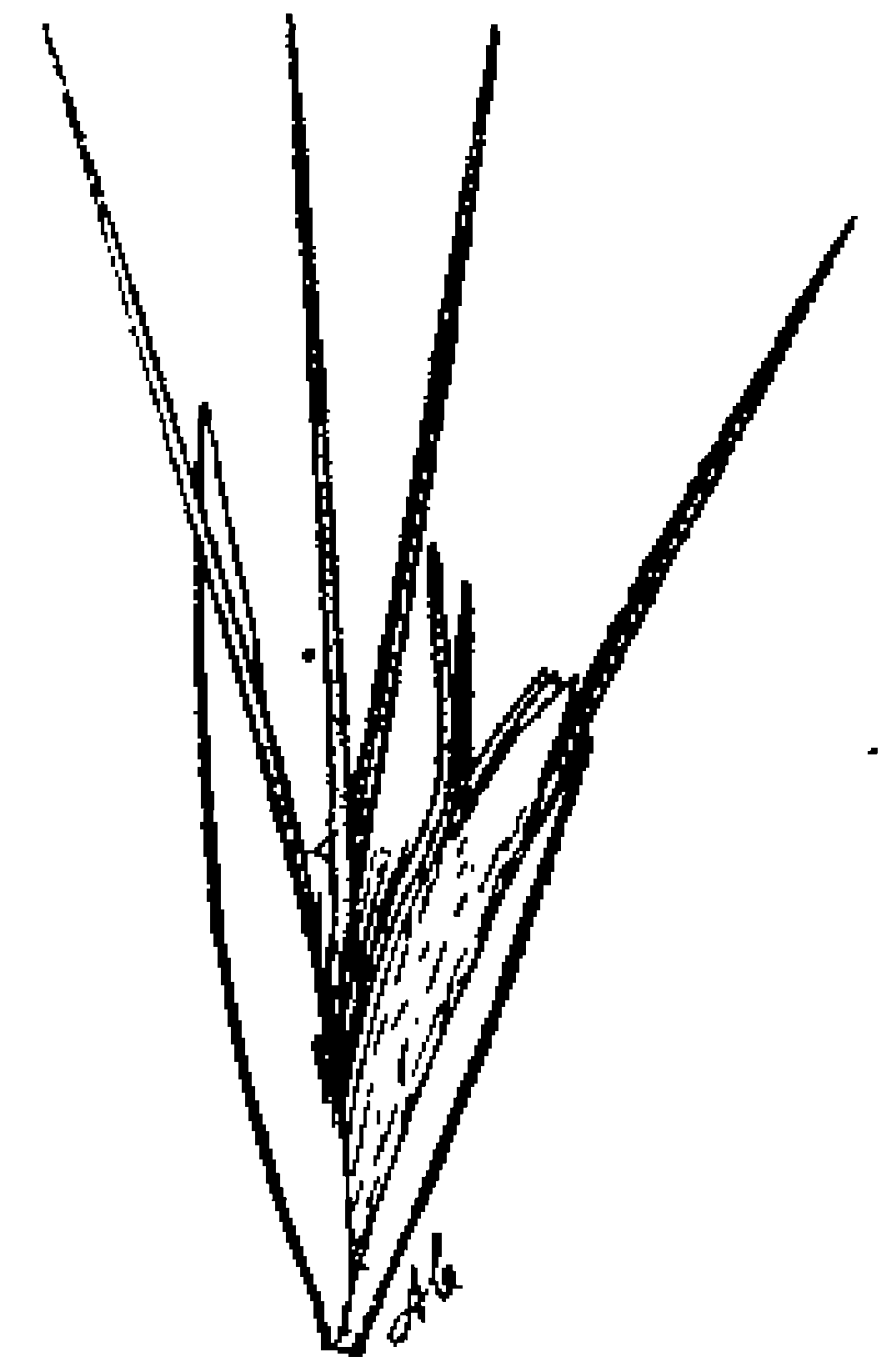

FIG. 28.-Bouteloua :implex. Spikelet. Scale 7.5. From typospecimen of B.rahmeri. ligule a conspicuous ring of short, white hairs; blades not abundant, short, narrow and inclined to be involute, about $3 \mathrm{~cm}$. long; spikes terminal, normally 1 but some-

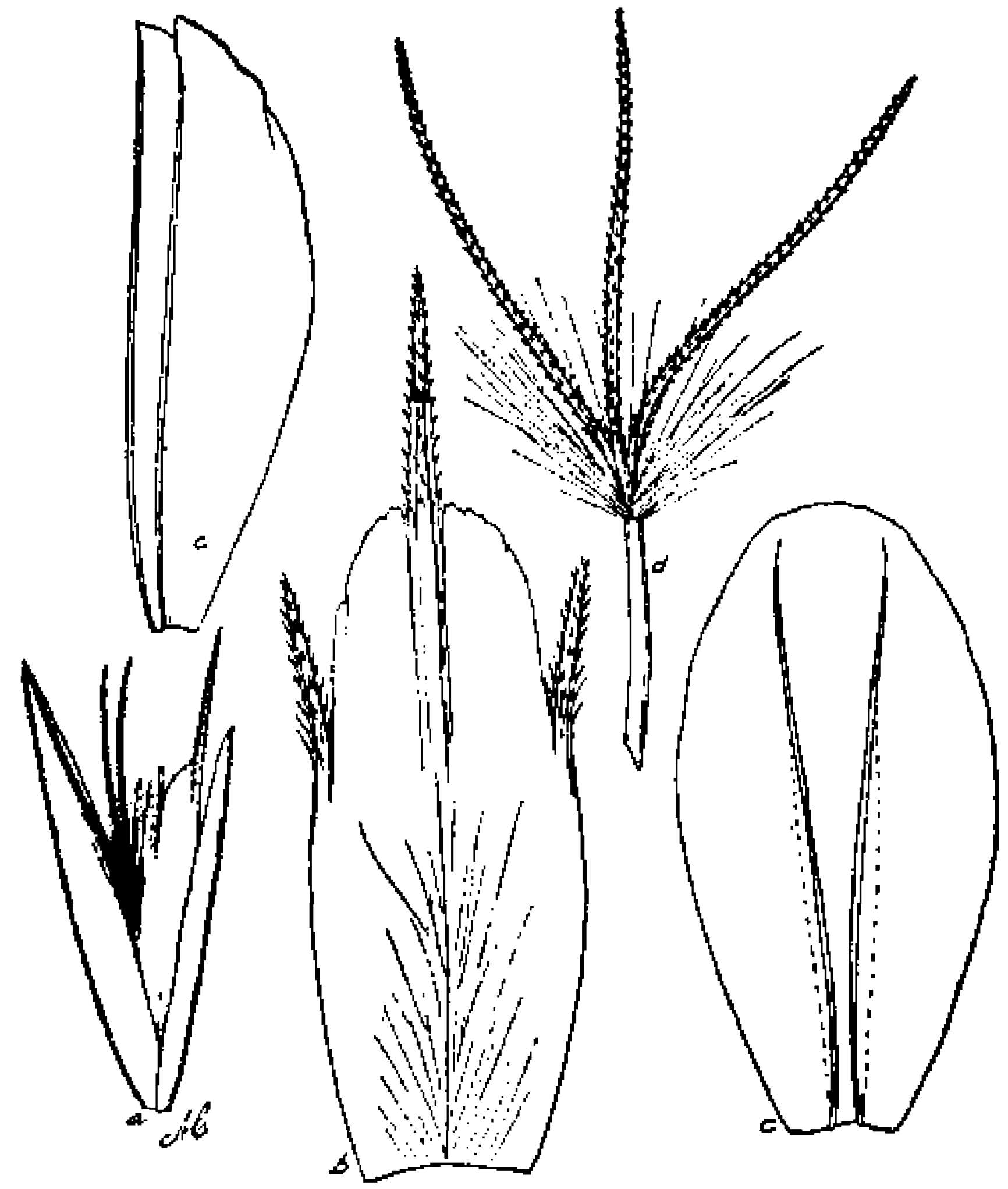

Fı. 29.-Bouteloua simplex. a, Spikelet; b, c, lemma and two views of palet of first floret; $d$, rudiment. $a$, Scale 7.5; $b-d$, scale I5. From type specimen of $B$, brachyathera. times 2 to 4 , congested at the apex of the culm, varying from 2 to 4 $\mathrm{cm}$. long, straw colored to purpligh-tinged; spikelets commonly about 50 , about $8 \mathrm{~mm}$. long, including the awns, pectinate, consisting of a lower perfect floret and a rudiment; glumes sharply and hispidulously keeled, otherwise smooth, the lower about 3 $\mathrm{mm}$., the upper 5 to $6 \mathrm{~mm}$. long; lemma, including awn, about 6 mm. long, covered on the back with a long, scattered pubescence, 3-awned, the central awn $2 \mathrm{~mm}$. longer than the lateral; palet smooth, obovate, awnless; rudiment consisting of 3 hispid awns, 5 or $6 \mathrm{~mm}$. long, together with a few ecales at base borne upon a hairy, tufted pedicel about 1 mm. long; caryopais more or less triangular in vertical section, about 1.5 to $1.75 \mathrm{~mm}$. long, alightly curved, the scutellum covering about two-thirds of the ventral surface. (FIGURes 28, 29.)

This description is drawn from Miguel Bang's no. 81, in the John Donnell Smith Herbarium, from the vicinity of La Paz, Bolivia, altitude 10,000 feet. The original 
description of the species is short: "culmo simplici, erectiusculo, monostachio: spica terminali, oblonga, glaberrima." This was written in 1805. In his later work, $a$ Lagasca added to this the two facts that the habitat of the plant is Poru and that it is an annual. These facts in connection with the above description satisfy me that

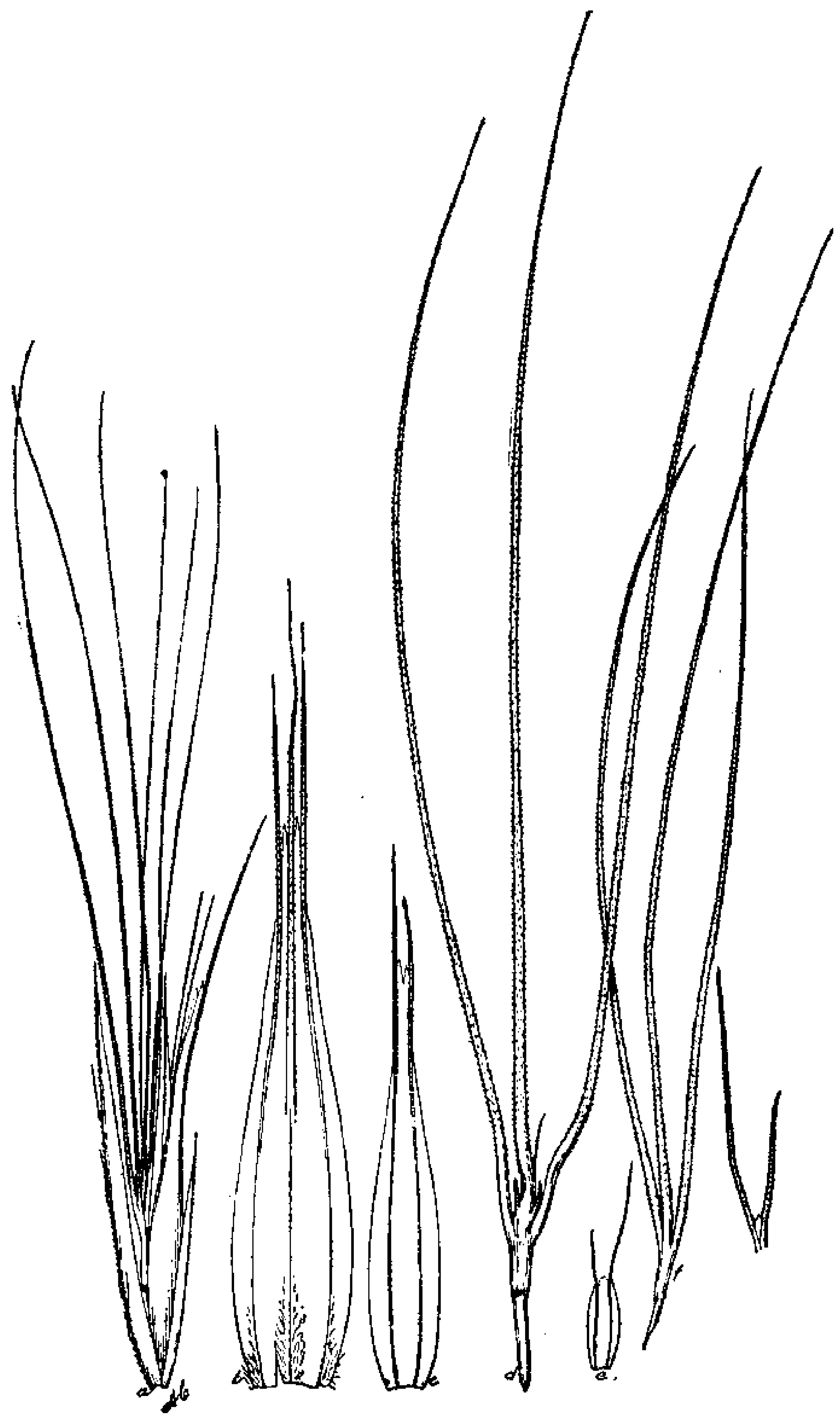

FIG. 30.-Bouteloua stolonifera. a, Spikelet; $b, c$, lemma and palet of first floret; $d, e$, rudimentary lemma and palet of second loret; $f, \theta$, rudimentary third and fourth florets. $a$, scale $7.5 ; b-a$, scale 10 . From type specimen.

Lagasca had the South American form of what he described in the next paragraph as $B$. prostrata. Philippi gave two names to this species. His $B$. brachyathera is a single-spiked immature plant, but unmistakably this species. The type of his $B$. rahmeri is fragmentary and immature, having 2 or 3 spikes aggregated at the apex 
of the culm. There are no differences between them in the spikelets and floral details. Miguel Bang's no. 81, of the John Donnell Smith collection, combines these two characters in one plant. Both of the Philippi specimens are from the Province of Tarapaca in the extreme northern part of Chile. South American material is very scanty in North American herbaria, and it may be that when more of it becomes available a still closer relation will be shown between this and $B$. procumbens.

\section{HERBARIUM BPECIMENS.}

South America: Fries 1058a, Bolivia; 813, Argentine. Bang 81, Bolivia. Philippi, 267 and 208, Chile. Rusby 34, Bolivia. Stuckert, Herb. Argent. 17700.

\section{Bouteloua stolonifera Scribn.}

Bouteloua stolonifera Scribn. Proc. Acad. Phila. 1891: 302. 1891. The type is Pringle 3174, in the U. S. National Herbarium, from Honda Station, Zacatecas, Mexico, August 19, 1890.

\section{DESCRIPTION.}

A densely tufted, strongly stoloniferous, low, smooth perennial; sheaths short, indistinctly striate; blades flat, narrow, 3 to $5 \mathrm{~cm}$. long, with involute edges, minutely scabrous under a lens, abundant and mostly radical; spikes solitary upon short, erect or ascending culms, 5 to $10 \mathrm{~cm}$. high, recurved into a circle when mature, 2 to $2.5 \mathrm{~cm}$. long; spikelets lax, 15 to 20 , pectinate, about $15 \mathrm{~mm}$. long including awns; glumes lanceolate, acuminate, the first 5 and the second $8 \mathrm{~mm}$. long, smooth or minutely hispidulous on the keel; lemma smooth, 8 to $10 \mathrm{~mm}$. long, including 3 long, unequal, hispid awns, the central 1 to $2 \mathrm{~mm}$. longer than the lateral; palet about $5 \mathrm{~mm}$. long, narrow, with involute margins, the 2 awns about $1 \mathrm{~mm}$. long; rudiment consisting of 2 or 3 aborted florets in the shape of 5 to 8 or more long, hispid awns and 3 to 5 small scales upon a short stipe about $1 \mathrm{~mm}$. in length; caryopsis not seen. (FraURE 30.)

When not headed out this species resembles somewhat the female plants of $B u l b i$ lis dactyloides. It often grows thick enough in shallow depressions in the mesas to make a semblance of a turf. Extensive areas of it have not been seen.

HERBARIUM SPECIMENS.

Mexico: Lloyd 104, Cedros, Zacatecas. Schaffner 1879, San Luis Potosí. Pringle 3174, La Honda Station, Zacatecas.

\section{Bouteloua scorpioides Lag.}

Bouteloua scorpioides Lag. Gen. \& Sp. Nov. 5. 1816. This species is identified on no other evidence than the brief description, "Culmo erecto filiformi monostachyo: spica lineari-oblonga spiraliter revoluta," and the additional information that the plant is from "N. Hisp." and perennial. Fournier referred this to Chondrosium tenue II. B. K., to which it is closely allied, the difference between them consisting chiefly in the perennial character of Bouteloua scorpioides. Fournier does not appear to have seen this species at all and consequently it was perfectly natural for him to refer this name to the annual C. tenue, which it so closely resembles.

Actinochloa? scorpioides Roem. \& Schult. Syst. Veg. 2: 420. 1817. Based upon Bouteloua scorpioides Lag.

Atheropogon scorpioides Spreng. Syst. Veg. 1: 293. 1825. Based upon Bouteloua scorpioides Lag.

Chrondrosium scorpioides Kunth, Rêv. Gram, 1:94. 1829. Based upon Bouteloua scorpioides Lag. 


\section{DESCRIPTION .}

A smooth, cespitose, half-prostrate or spreading perennial; culms ascending, seldom geniculate or branched, 20 to $30 \mathrm{~cm}$. long; sheaths striate, smooth, close; blades narrow, involute, short, only 4 or $5 \mathrm{~cm}$. long, with a narrow ligular fringe of white hairs;

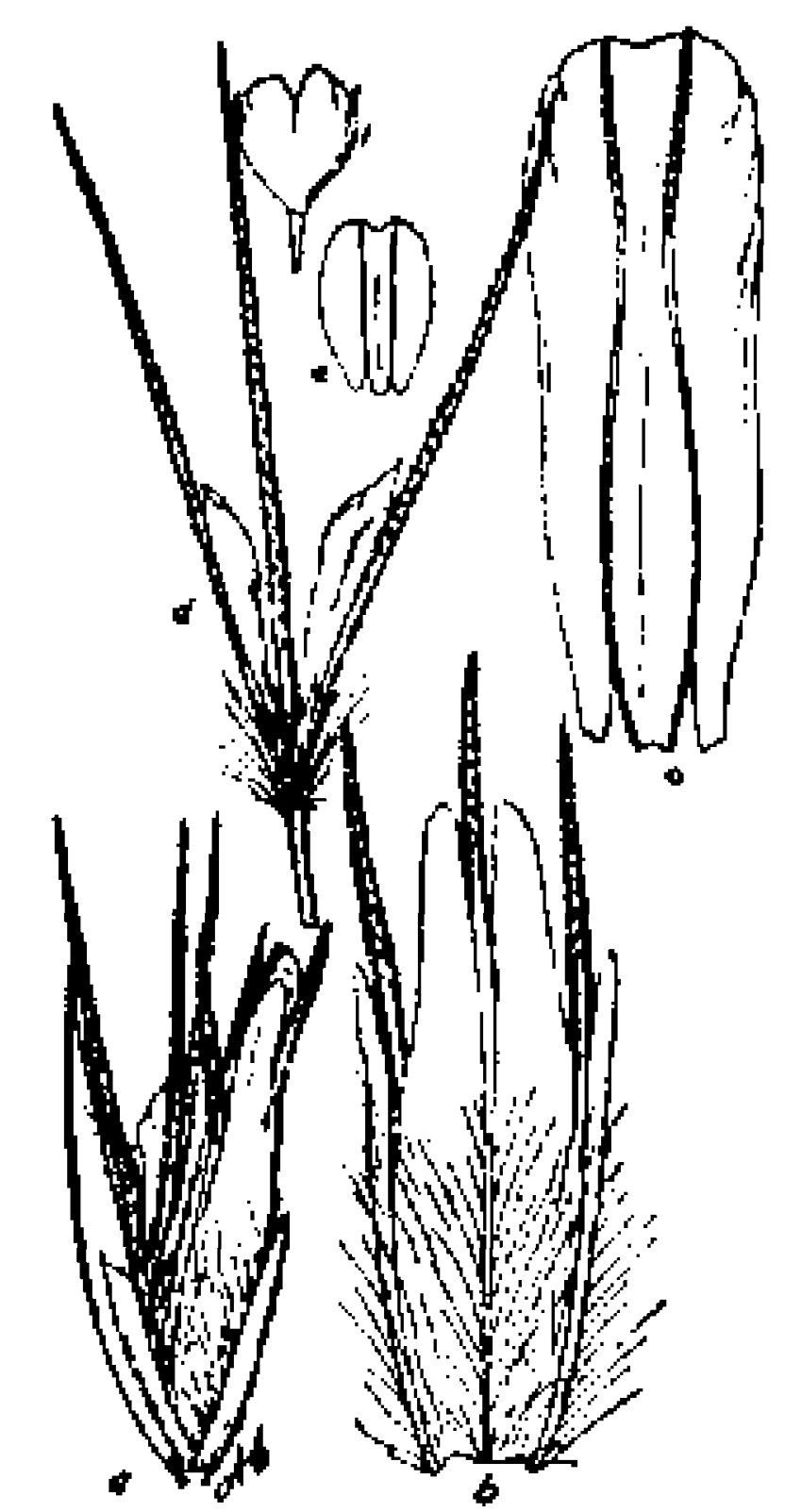

Fig. 31.-Bouteloua scorpioIdes. $a$, Spikelet; $b, c$, lemma and palot of first loret; d, $e$, rudimentary lemma and palet of second floret; $f$, rudiment of third floret. a, Scale 5 ; $b-f$, scale 7.5 . From Pringle 8820. spike always solitary and terminal, 4 to $5 \mathrm{~cm}$. long, revolute toward maturity; spikelets 50 to 70 , pectinate, about $6 \mathrm{~mm}$. long, consisting of a lower floret and anupperrudiment; glumessmoth, not sharply keeled, rounded to abruptly pointed, awnless, the lower 3.3 $\mathrm{mm}$, , the upper 5.3 $\mathrm{mm}$. long; lemma densely hairy, 5.5 mm. long, with 3 equal awns and 4 lobes, the two central lobes being nearly as long as the awns, the lateral lobesshort and attached nearly the entire length to the lateral awns; palet as long as the lemma, truncate, awnless; rudiment $5.5 \mathrm{~mm}$. long, hairy-tufted, with 3 equal scabrous awns and 2 axillary scales representing the lobes of the lemma; caryopsis not seen. (Figures 31, 32.)

This species is as unitormly 1-spiked as is $B$. procumbens. In other respects the herbarium malerial bears a close similarity to some single-spiked forms of $B$. gracilis. On the whole, however, the plants as well as the glumes are smoother and the spikes are longer, hesvier, and more revolute. In the field the difference is atill more striking. In this species the larger plants grow in more conspicuous bunches and are more spreading, and the general aspect, owing Fra. 32.-Bouteloua scorpioidcs. a, Spike; $b$, spiketo this fact and the lack of pubescence, is let; $c, d$, lemma and palet of first loret; $e$, rudientirely different. One-spiked forms of $B$. gracilis are not at all uncommon. Such

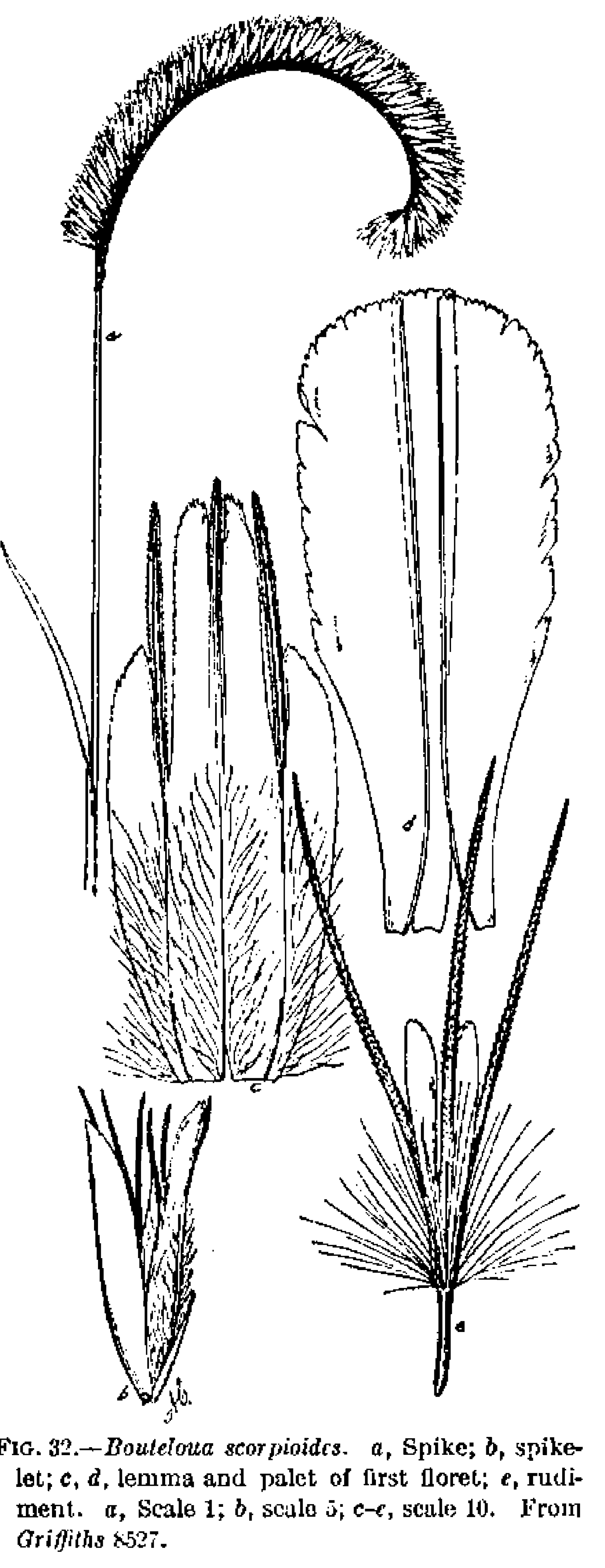
forms might easily be confused with $B$. scorpioides by ono who had never seen the latter in the field. The range of $B$. scorpioides, however, is apparently limited to the high plateau of central Mexico. One-spiked forms that have been examined from northern Mexico or the United States can not be referred to this species.

When Pringle's no. 8820, from Zontecomate Station, IIidalgo, Mexico, was first seen it was thought that it was a distinct species. Pittier's no. 422, from the State of 
Puebla, and Lloyd 105, from Hacienda de la Cedros were placed with the Pringle collection. Later collections by myself, however, from the Valley of Mexico connect the small, narrow-leaved plants represented by Pringle 8820 , with my large, comparatively wide-leaved plant from Encinillas. The species appears to vary from the large plant described above to a diminutive plant often not over 7 or $8 \mathrm{~cm}$. high, having narrow, rather rigid, mostly radical leaves. The smaller forms resemble $B$. procumbens except that they are perennial, while the larger ones look more like singlespiked plants of $B$. gracilis.

The species has been collected at various places from northern Zacatecas to Orizaba and is especially abundant in the Valley of Mexico although not at all common in collections. Doubtless the common form of the Valley of Mexico may be found included with $B$. procumbens in some herbaria.

\section{Bouteloua hirticulmis Scribn.}

Bouteloua hirticulmis Scribn. U. S. Dept. Agr. Div. Agtost. Circ. $30: 4$. 1901. The type is T.S. Brandegee's no. 11, collected September 29,1899 , at Sierra de San Francisquito, Lower California.

\section{DESCRIPTION}

A cespitose, erect, stout cerennial, about $60 \mathrm{~cm}$. high; culms simple, densely hirsute-pubescent below but naked above; sheatins short, striate, glabrous or with a few scattered hairs; ligule conspicuously ciliate-hairy; blades 10 to $20 \mathrm{~cm}$. long, flat, minutely scabrous, tubercular-hairy near base; epikes 2 or 3 , apparently normally 2 , about $5 \mathrm{~cm}$. long, upon ahort, curved, woolly peduncles, the rachis projecting 1 to $2 \mathrm{~cm}$. beyond the distal spikele ts; spikelets pectinate, numerous, 50 to 60 , about $6 \mathrm{~mm}$. long; glumes lanceolate, subulate-pointed, pubescent, the first

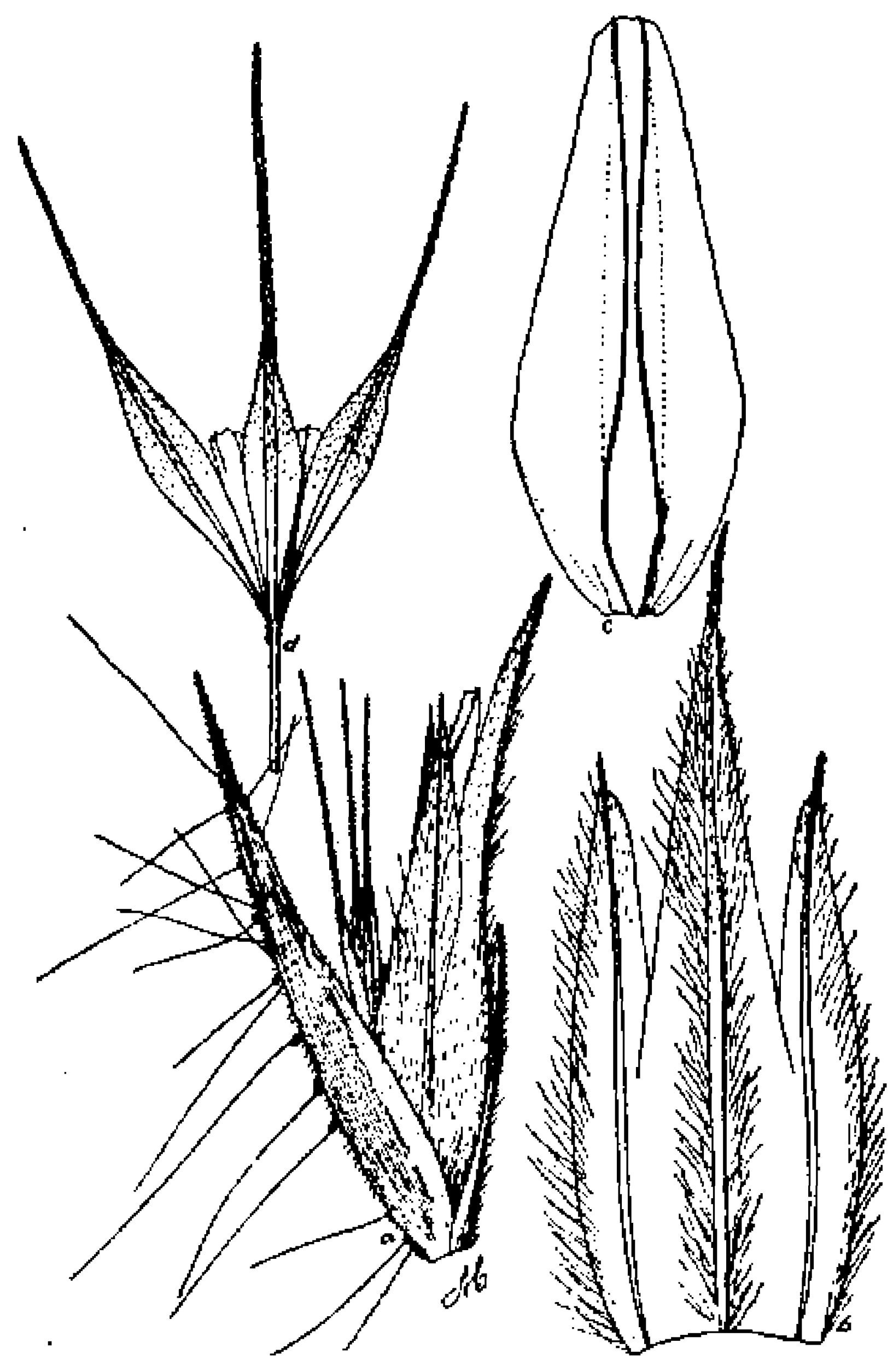

FIG. 33.-Bouteloua hirticulmis, $a$, Spikelet; $b, c$, lemms and palet of first floret; $d$, rudiment. $n$, scale 7.5; $b-d$, scale 10. From type specimen.

\section{5 to $3 \mathrm{~mm}$. long, the second 5 to}

$5.5 \mathrm{~mm}$. Iong, the latter bearing upon the dorsal surface long papillose hairs, 1 to $3 \mathrm{~mm}$. in length, much like those of $B$. hirsuta; lemma 3-lobed, with short awns from the 3 nerves, the central lobe 1 to $1.5 \mathrm{~mm}$. longer than the lateral pair, hairy, especially on the nerves; palet 2-nerved, awnless, glabrous, narrowly ovate, 4 to $5 \mathrm{~mm}$. long; rudiment consisting of 3 scabrous awns, 3 to $4 \mathrm{~mm}$. long, expanded and scale-like below, the central slightly the longest, interspersed with 2 or 3 acales on a naked stipe 1 to 1.5 $\mathrm{mm}$. long, bearing a few hairs at its apex; caryopsis not known. (FIoURe 33.)

This can be looked upon as a robust, hirsute, hairy-culmed form of $B$. hirsuta. Its tuberculate-hairy second glume and woolly culms are its distinguishing characteristics.

Palmer's no. 201, and Neleon's no. 1259 are typical. Nelson's no. 3121 (Roadside between Tuxtla and San Cristobal, Chiapas, Mexico, September, 1895, in U. S. National Herbarium) includes $B$. hirsuta and $B$. hirliculmis mounted on the same sheet, indicating that the collector considered them the same species and probably 
found them growing intermixed. This still further goes to prove the close relationship of the two species and really throws a doubt upon the validity of B. hirliculmis. My own collection from western Jalisco illustrates the same close relationship. Indeed, frequent gradations may be found between this and $B$. hirsuta in the mounlains northwest of Guadalajara. In the vicinity of Aguascalientes the species has less hairy culms, as shown by some of my own distributions. Further collections from the Pacific coast of Mexico, from Lower California to the Isthmus are necessary.

HERBA IUIUM SPECIMENS.

Mexico, Brandegee, El Tase, Lower (alifornia. Nelson 3121 (in par1), (hiapas; 1259, Valley of Oaxaca. Palmer 201, Rio Blanco, Jalisco.

\section{Bouteloua hirsuta Lar.}

Bouteloua hirsuta Iag. Var. Cienc. 24:141, 1805. My interpretation of this is based upon the description and upon a specimen sent by Lagasca to Munich in 1820 . A specimen in the herbarium of the Madrid Botanical Garden marked $B$. hirsuta in Lagasca's hand has both $B$. hirsuta and $B$. gracilis on the same sheet. This, however, is not the type, for that was burned in Lagasca's first herbarium. The spike of $B$. hirsuta from this specimen before me is very large and represents the largest of our southern forms of this species. The Munich and Madrid specimens appear to be from the same collection. See also U. S. Dept. Agr. Div. Bot. Bull. $12^{1}: p l$. $\$ 9 . f .1-s$. 1890; Britt. \& Brown, Illust. Fl. $1: 180 . f .411$. 1896; U. S. Dept. Agr. Div. Agrost. 7: 223.f. 205. 1897 .

Bouteloua hirta "H. R. M."'a Lag. Var. ('ienc. 24:141. 1805. A garden name mentioned as a synonym of Bouteloua hirsuta; B. hirta Scribn.b is based on Chondrosium hirtum $\mathbf{B}$. B. K.

Chondrosium hirtum H. B. K. Nov. Gen. \& Sp. $1: 176 . p l .59 .1816$. The plate identifies this without doubt, although the species normally bears 2 to 4 spikes, not one spike as figured and described.

Actinochloa hirsuta Roem. \& Schult. Syst. Veg. 2: 419. 1817. Based upon Bouteloua hirsuta Lag.

Eutriana hirta Trin. Gram. Unifl, 240. 1824. Based upon Actinochloa hirsuta Roem. \& Schult.

Atheropogon hirtus Spreng. Syst. Veg. 1: 293. 1825. Based upon Chondrosium hirlum $\mathbf{H} . \mathbf{B} . \mathbf{K}$.

Chondrosium hirsutum Sweet, Hort. Brit. 1: 455. 1826. A name only.

Atheropogon papillosus Engelm. Amer. Journ. Sci. 46:104. 1843. The description is sufficient to identify this. The type, in the Engelmann Herbarium, is Geyer's specimen collected near Beardstown, Illinois, in 1842. A specimen so named corresponding to this description in the Gray Herbarium further identifies it. This is mounted on the same sheet as Mead's specimen from Mason County, Illinois, collected August 25, 1845.

Chondrosium aschenbornianum Nees, Linnaca $19: 692.1847$. The type is Aachenborn Exsic. no. 331. The epecimen of this in Willdenow's herbarium is Boutrloua hirsuta. Fournier has listed many numbers from Mexican collectors under this name but all others examined from whatever source are $B$. gracilis. As an illustration of the mix up, my notes on Bourgeau's no. 448 are in teresting. In the National Herbarium $B$. gracilis and $B$. hirsuta are found under this number on the sume gheet. In the Gray Herbarium, and the herbaria at Paris and at the St. Petersburg Botanical Garden, this number is $B$, gracilis, while a duplicate of the type in the Willdenow Herbarium is $B$, hirsuta.

a I. e., Hortus Regius Matritensis.

b Contr. Nat. Herb. 2: 531. 1894. 
Chondrosium foenum Torr. in Emory, Mil. Reconn. 154. pl. 12. 1848. The plate is auficient to identify this.

Chondrosium papillosum Torr. in Marcy, Expl. Red. Riv. 300. 1852. Based upon Atheropogon papillosus Engelm.

Bouteloua foena Torr. Cat. Pl. Surv. W. 100th Merid. 18. 1874. Based upon Chondrosium foenum Torr.

Chondrosium drummondii Fourn. Mex. Pl. 2 : 137. 1881. The type number (Drummond 323) in the herbarium of the Muséum at Paris and in the herbarium of the St. Petersburg Botanical Garden belong to this species, but the prolongation of the rachis is rather short in the fragments before me from both the above depositories. A photograph of the type taken for me by $A$. S. Hitchcock in 1907 represents the typical form of the species.

Bouteloua aschenborniana Griseb.; Fourn. Mex. Pl. 2: 137. 1881. A manuscript name mentioned as a synonyın of Chondrosium aschenbornianum Nees.

Bouteloua palmeri Vasey, Bull. Torrey Club 14: 9. 1887. A name only. Vasey observes that this species, which was distributed to some extent under this name, is a variety of $B$, hirsuta.

Bouteloua hirsuta minor Vasey, U.S. Dept. Agr. Div. Bot. Bull. $12^{1}: p l .39 . f .2$. 1890. See $B$. hirsuta major. The type of this variety appears to be a specimen collected in Texas, 1883 , by $\mathrm{S}$. B. Buckley.

Bouteloua hirsuta major Vasey, U. S. Dept. Agr. Div. Bot. Bull. $12^{1}: p l . s 9 . f . s$. 1891. The specimen in the National Herbarium locates Vasey's work without doubt, although the label is not in Vascy's writing.

Bouleloua hirsula palmeri Vasey; Beal, Grasses N. Amer. 2: 417, 1896. Vasey says $a$ that this has been distributed as $B$. palmeri, but he refers it to $B$. hirsuta. The specimen in the National Herbarium plainly marked by Vasey "Cultivated from seed collected by Palmer in Mexico, 1886," fixes the type without any question. Watson $b$ also uses this name.

Bouteloua bolanderi Vasey; Beal, Grasses N. Amer. 2: 417. 1896. Beal mentions this as a synonym under $B$. hirsuta variety palmeri. It is said to have been cultivated from seed collected by Palmer in Mexico in 1886 . I have not been able to find in the National Herbarium any specimen marked $B$. bolanderi.

Bouteloua hirta Scribn. Contr. Nat. Herb, 2: 531. 1894. Based on Chondrosium hirtum H. B. K.

Bouteloua hirta major Vasey, Contr. Nat. Herb. 2 : 531.1894.

Bouteloua hirta minor Vasey, Contr. Nat. Herb. 2 : 531. 1894.

\section{DEBCRIPTION}

A cespitose, rigid, erect perennial of very variable habit, eize, and general appearance, in the northern portion of the Great Plains forming a sod, but in the Southwest and in Mexico growing in isolated clumps, rather rigid and stout, with unbranched culms, smooth, striate, close sheaths, small, ciliate ligule, and flat, somewhat hispid, narrow blades, more numerous below than above; panicle racemose, 3 to $5 \mathrm{~cm}$. long, bearing 1 to 4 spikes, normally 2 in the north but more commonly 3 or 4 in the south, 2.5 to $3.5 \mathrm{~cm}$. long, with a projection of the rachis 5 to $8 \mathrm{~mm}$. beyond the last spikelets; spikelets numerous, 35 to 45 , pectinate, consisting of a lower, fertile floret and an upper rudiment, glumes unequal, the first minutely hispid, about $3 \mathrm{~mm}$. long, acuminate, the second acuminate, short-awned, about $6 \mathrm{~mm}$. long, minutely hispid and conspicuously tuberculate-hairy; lemma 3 -toothed, the central tooth terminating in a short, hispid awn alightly longer than the lateral teeth, these simply acuminate-pointed, conspicuously pubescent; palet oval, broadly pointed; rudiment consisting of 3 hispid, equal awns, about $6 \mathrm{~mm}$. long, and one or two small scales upon a stipe, 1 to $2 \mathrm{~mm}$. 
long, the latter slightly pubescent above; caryopsis about 1.5 to $2 \mathrm{~mm}$. long, $0.5 \mathrm{~mm}$. wide, oval, more or less pointed at both ends, the scutellum covering nearly the entire ventral surface and the embryo extending nearly to the apex. (Figure 34.)

The distribution of this species is very wide, from British Columbia southward through the continental highland and again at points along the Gulf coast in Florida. $A B$ in the case of $B$. gracilis the northern and southern forms differ widely in both habit and general aspect, the northern being shorter as a rule and showing a tendency to form a sod, while the southern is in the strictest sense a bunch grass. It reaches its best development upon stable, sandy-loam soils and extends in New Mexico and Arizona into the upper foothills. The most abundant development that has been met

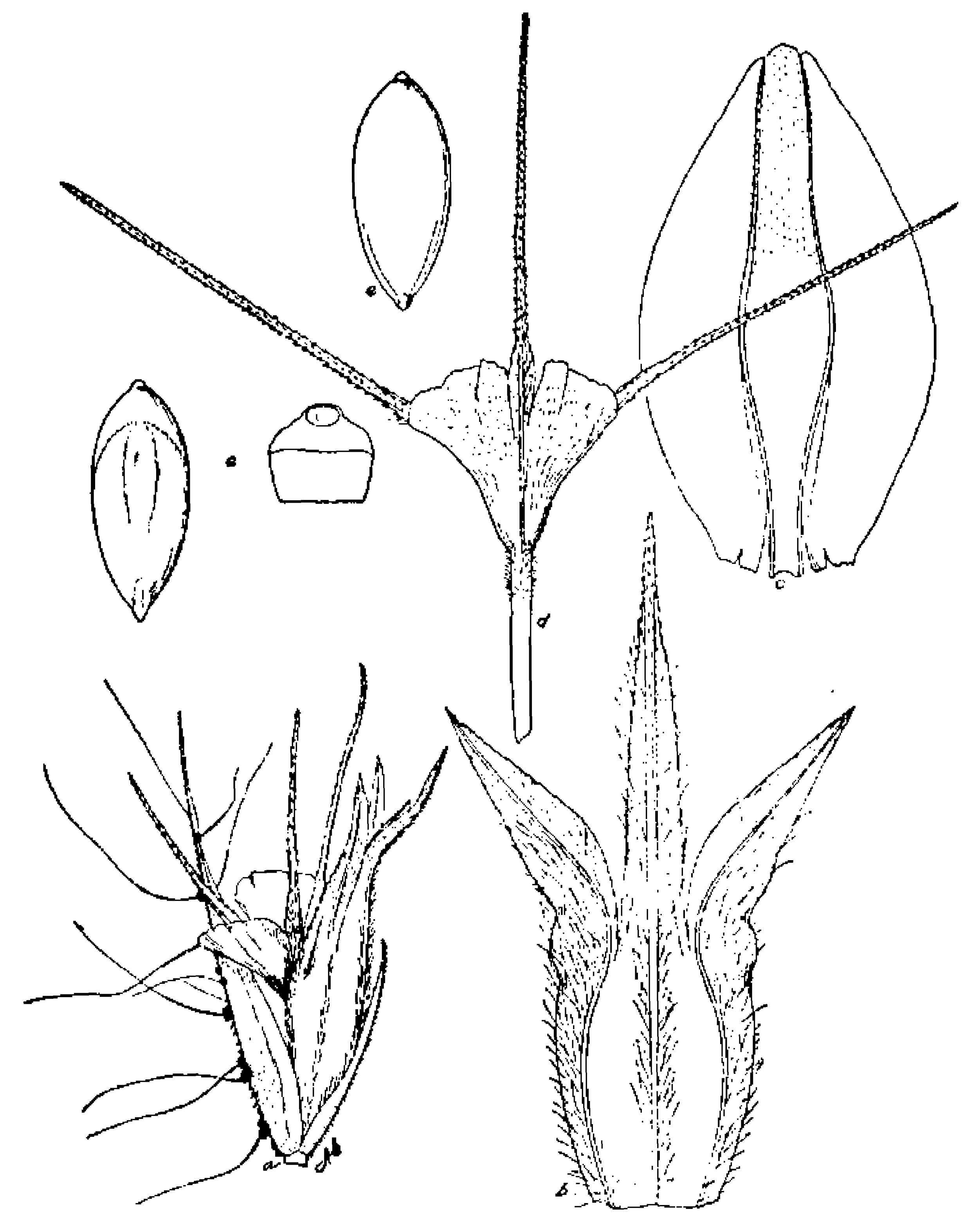

FIg. 34,-Bouteloua hirsuta. $a$, Spikelet; $b, c$, lemma and pilet of first horet; $d$, rudlment; $\varepsilon$, two views and cross section of caryopsis. a, Scale $7.5 ; b-c$, sale 12.5 . From Griffith 6125 .

with is in the sandy lande of the Texas-New Mexico line cast of Roswell and in foothills from Arizona south. In the former situation this and two or three speriss of Andropogon constitute about the only forage. It also grows almost to the exclusion of all else in localities upon the platenu of central Mexiro.

The species is well understood and seldom incorrectly named in collections. Its distinguishing characteristics are the prolongation of the rachis beyond the spikeleta, the tuberculate, hairy glumes, and the more or less papillose-hairy leaf margins. Heller 1878, Lemmon 3175 and 4073, I'ringle 409, and Palmer 1357 are typical. Clements's no. 1 (Manitou, Colorado) and Rydberg's no. 1552 are 1-spiked forms which are common enough, but not so commonly collected. 
HERBARIUM SPECIMENS.

Arizona: Jones 540, Bowie. Lemmon 4639, 4637, and 4640, S. E. Arizona; 3175. Sulphur Spring Valley. MacDougal 616, Beaver Creek. Toumey 26, Prescott, Griffths 1865, Dragoon Mountains; 1948, Pearce; 1809, Rincon Mountains; 3375 and 3371, Santa Rita Mountains. Griffiths \& Thornber 26 and 222, Santa Rita Mountains. Hitchcock 3700, Patagonia; 3732, Benson.

Colorado: Williams 2117, Colorado Springs. Rydberg 2360, Meadow Park. Hitchcock 2270, Ouray.

Florida: Simpson (December, 1891). Garber (November, 1878). Combs \& Baker 1105, Orange County. Baker 33, Orange County.

Ilinnors: Patterson 590, Oquawka. Wilcox 58, on Mississippi River; 41, Aurora; 63, Manito. Gleason 1003, Havana.

Iow A: Ball 116, Ames.

Kansas: Smyth 78, Greensburg. Shear 147 and 702, Osborne. Norton 908, Riley County. Thompson 125, Syracuse.

Missouri: Bush 389a, Atchison County.

Nebraska: Rydberg 1552, near Mullen. Morris 434a. Williams 3008, Weeping Water. Clements 2738, Pishelville. Elmer 133, Crete.

New Mexico: Wooton 419 and 1098, Organ Mountains. Vasey 101, Organ Mountains, Metcalfe 754, Bear Mountains. Plank 19, Socorro. Greene 403, Silver City. Ifitchcock 3790, Organ Mountains. Standley 4977, San Miguel County. Fendler 951 of 1847.

South Dakota: Thomber 242, Sioux Falle. Rydberg 1135, Hot Springs.

Texas: Riggs 66, Marshall. Lindheimer 731 (Fasc. IV). Jermy 781, Gillespie County. Nealley 353 and 93, Santa Ana. Letterman, San Antonio(1882). Buckley (1881). Meller 1878, Kerrville. Reverchon 4216 and 1153, Dallas; 4, Comanche Peak; 4089, Wood County. 'Bailey 740, Guadalupe Mountains; 393, Chisas Mountains. Tracy 8205, Dallas; 8221, Colorado; 8213, Weatherford; 8214, Big Springs; 8205, Fort Worth. Ball 994 and 893, Chillicothe.

Mexico: Conzatti 2013, State of Oaxaca. Schaffner 1018, San Luis Potosí; 158, Valley of Mexico. Pringle 409, Chihuahua; 11215, Tula. Wilkinson 347, Santa Eulalia Mountains. Brandegee 25, Cape Region, Lower California; 11, Sierra de Laguna, Lower California. Palmer 405, Saltillo; 807, Durango. Parry \& Palmer 943, San Luis Potosi. Nelson 6246, Pacheco, Chihuahua. Rose 1904 and 3293, Territory of Tepic; 2588, State of Jalisco.

7. Bouteloua gracilis (II. B. K.) Lag.

Actinochloa ciliata Willd.; Beauv. Ess. Agrost. 41. 1812. (See Chondrosium ciliatum.)

Chondrosium ciliatum Willd.; Beauv. Ess. Agrost. 158. 1812. Beauvois lists this name in the index, basing it upon the above manuscript name of Willdenow. In Beauvois's personal copy of his Essai, a he has written in the index in his own hand that this is C. gracile $\mathbf{H} . \mathbf{B} . \mathbf{K}$.

Chondrosium gracile H. B. K. Nov, Gen.\& Sp. 1 : 176. pl. 58. 1816. The cited plate and description, together with a specimen in Willdenow's herbarium, "ex herb. Humboldt ex herb. Kunth" leave no doubt in my mind that this is what in this country we have long called $B$, oligostachya. It is true that Kunth figures a single-spiked plant, which is the uncommon form. It is rather curious that Humboldt and Bonpland did not collect the more common form, but not nearly so curious as it would have been if they had not collected this widely distributed species at all. Kunth also figures a single-spiked form of $B$. hirsuta, though this is the less common form of that speciea.

a This copy is now in the library of the U. S. Department of Agriculture. 
Actinochloa gracilis Willd.; Roem. \& Schult. Syst. Veg. 2:418. 1817. Based upon Chondrosium gracile $\mathbf{H}$. B. $\mathbf{K}$.

Atheropogon oligostachyum Nutt. Gen. Pl. 1 : 78, 1818.

Eutriana gracilis Trin. Gram. Unifl. 240. 1824. Based upon Actinochloa gracilis Willd.

Atheropogon gracilis Spreng. Syst. Veg. $1: 293.1825$. Based upon Chondrosium gracile $\mathrm{H} . \mathrm{B} . \mathrm{K}$.

Eutriana? oligostachya Kunth, R6v. Gram. 1:96. 1829. Based upon Atheropogon oligostachyus Nutt.

Bouteloua grarilis Iar.; Steud. Non. Bol. ed. 2. 1 : 219. 1840. Based upon Chondrosium gracile H. B. K.

Chondrosium oligostachyum Torr. in Marcy, Expl. Red Riv. 300. 1852. Based upon Atheropogon oligostachyum Nutt.

Bouteloua oligostachya Torr.; $A$. Gray, Man. ed. 2. 553. 1856; see alao U. S. Dept. Agr. Div. Bot. Bull. 12 ${ }^{1}$ : pl. 41. 1890; Britt. \& Brown, Illustr. Fl. 1 : 180. f. 412. 1896; U. S. Dept. Agr. Div. Agrost. Bull. $7: 222$. . 204. 1897 and op. cit. $20: 106$ f. 80.1900.

Bouteloua oligostachya intermedia Vasey, Grasses U. S. 33. 1883. A name only. No specimen so marked can be found in the National Herbarium.

Bouteloua oligostachya major Vasey, Descr. Cat. Grasses U. S. 62. 1885; Dewey, Contr. Nat. Herb. 2 : 531. 1894; Beal, Grasses N. Amer. 2 : 418.1896.

Bouteloua major Vasey, Bull. Torrey Club 14:9. 1887. Vascy publishes a name only and refers to specimens previously distributed under it. He also states that this is a variety of $B$. oligostachya. The type is a specimen cultivated from seed collected by Palmer in Chihuahua, Mexico, in 1886.

Bouteloua stricta Vasey, Bull. Torrey Club 15: 49. 1888. A very brief description is given; a fuller description is furnished later ${ }^{a}$ The type is (.. G. Nealley, without number, western Texas, 1887. The species commonly assumes in the southwest the form represented by Vasey's type.

Bouteloua oligostachya pallida Scribn.; Beal, Grasses N. Amer. 2: 418. 1896. Pringle 407 is the duplicate type in the National Herbarium. There appears to be no good reason for recognizing such a variety. Pallid and dark-colored forms may be found in nearly all epeciea of the genus.

\section{DESCRIPTION}

A stout, erect, smooth, cespitose perennial, forming a rough sod in the north, but usually in isolated tufts in the south and much larger and ranker in growth; culms branched only at the very base if at all, sheaths loose, striate, smooth; ligule reduced to a line with at most only a few scattered hairs; blades linear, rather abundant, about 5 to $10 \mathrm{~cm}$. long, 1 to $2 \mathrm{~mm}$. wide, flat, minutely scabrous-margined; spikes normally 2 , often 1 or 3 or 4 , seldom 5 or 6 , very variable in length, commonly above $3 \mathrm{~cm}, b$ more or less recurved in age with no projecting sterile rachis; spikelets pectinate, on short, minutely pubescent, pedicels, numerous, often as many as 80 , consisting of a fertile flower and a rudimen1; glumes lanceolate, short-awned, keeled, minutely scabrous, the lower 3 to $3.5 \mathrm{~mm}$. long, the upper 5 to $6 \mathrm{~mm}$. long; lemma about $6 \mathrm{~mm}$. Iong, pubescent, 3-awned, the central awn slightly longer, all hirsute; palet about $5 \mathrm{~mm}$. long, shortly 2 -awned from the nerves, the latter slightly hirsute above; rudiment consisting of 3 scabrous, nearly equal awns with 2 or 3 scales at their bases all supported on a short stipe, 1 to $1.3 \mathrm{~mm}$. long, hairy-tufted at base and apex; caryopsis 2.5 to $3 \mathrm{~mm}$. long, $0.5 \mathrm{~mm}$. wide, concave on the dorsal and sharply convex

${ }^{a}$ U. S. Dept. Agr. Div. Bot. Bull. $12^{l}: p l .45 .1890$.

b One specimen without data from Thurber's herbarium in Herb. Mo. Bot. Gard. has spikes $9 \mathrm{~cm}$. long. 


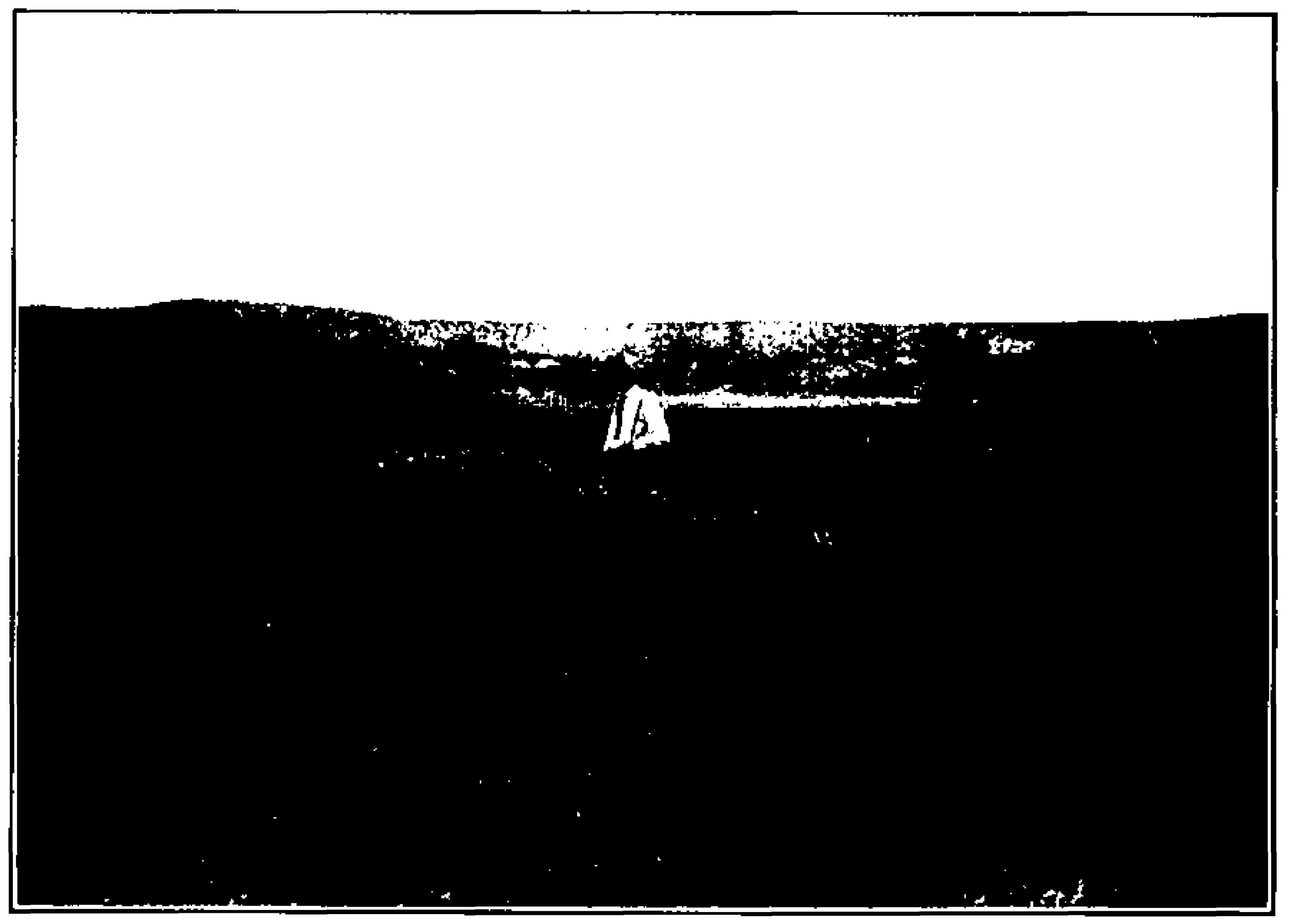

A. Large native crop iff Bouteloua gracilis ' H. B. K.' Lag.

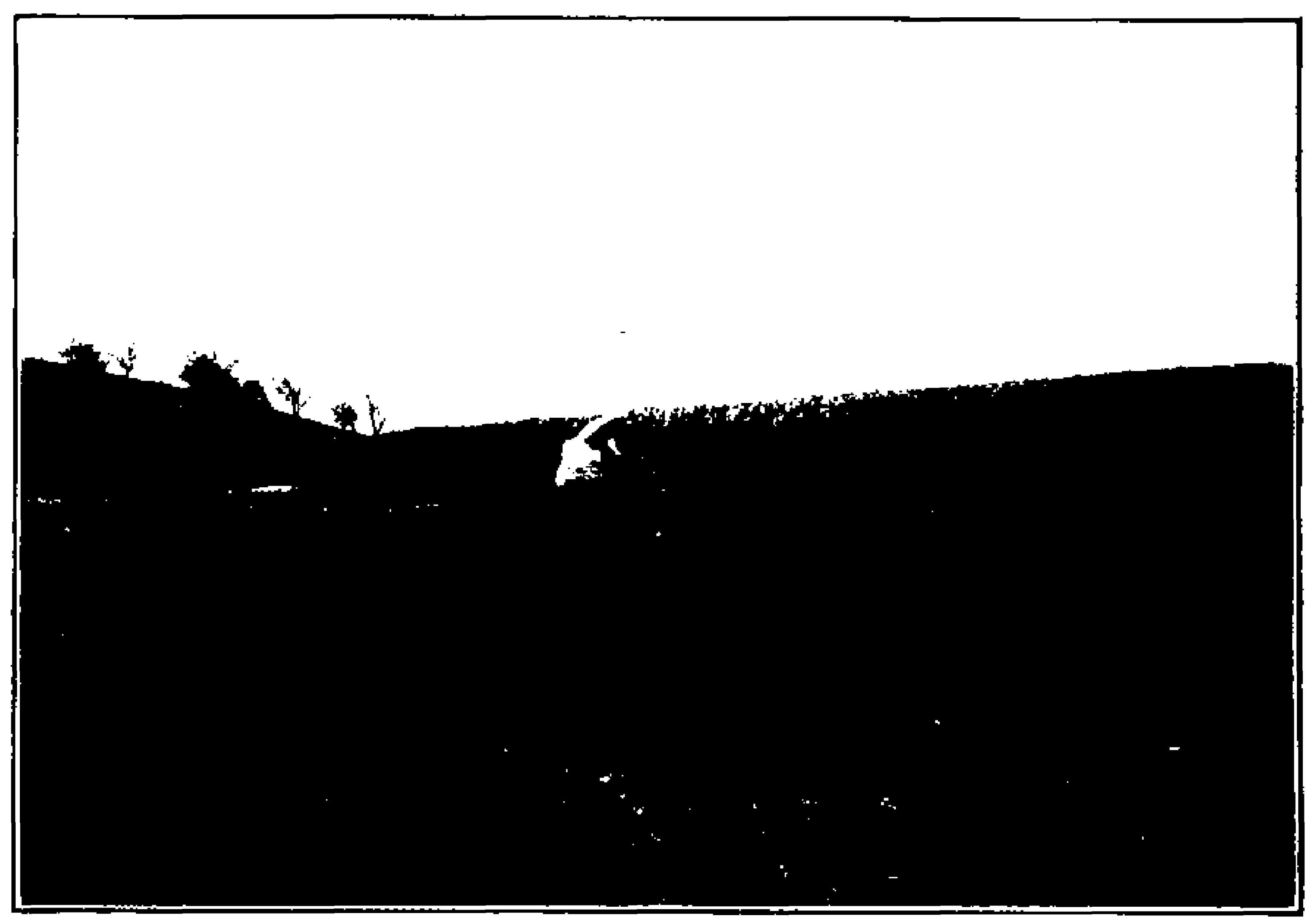

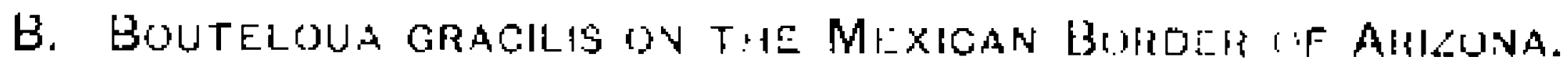


on the ventral surface, the scutellum covering over three-fourihs of the ventral surface. (Plate 72, A, B. Figure 35.)

This is without doubt the most important economic species of the genus, extending from Manitoba to South America. It is doubtfully reported from Tampa, Florida. As would be expected from a plant of such wide range, it is extremely variable. The above description is drawn in the main from my no. 6108 from the Sonoyta Valley of Arizona, which is very different from the plains region form. The latter produces a rough, rather bunchy sod and sends up but few culms, the abundant basal leaves forming a curly covering close to the ground, the species on this account often being confused in the popular mind with the buffalo grasa (Bulbilis dactyloides). But in the southern desert region where, along the Mexican border, it grows in abundance at an altitude of about 5,000 feet it is usually in isolated large bunches. In favorable eituations in swales such as are found on the eastern slope of the Santa Rita Mountains of Arizona it assumes more nearly the appearance of the northern form so far as haljit is concerned (PI. 72, B). In the South the plants usually grow much larger, It is

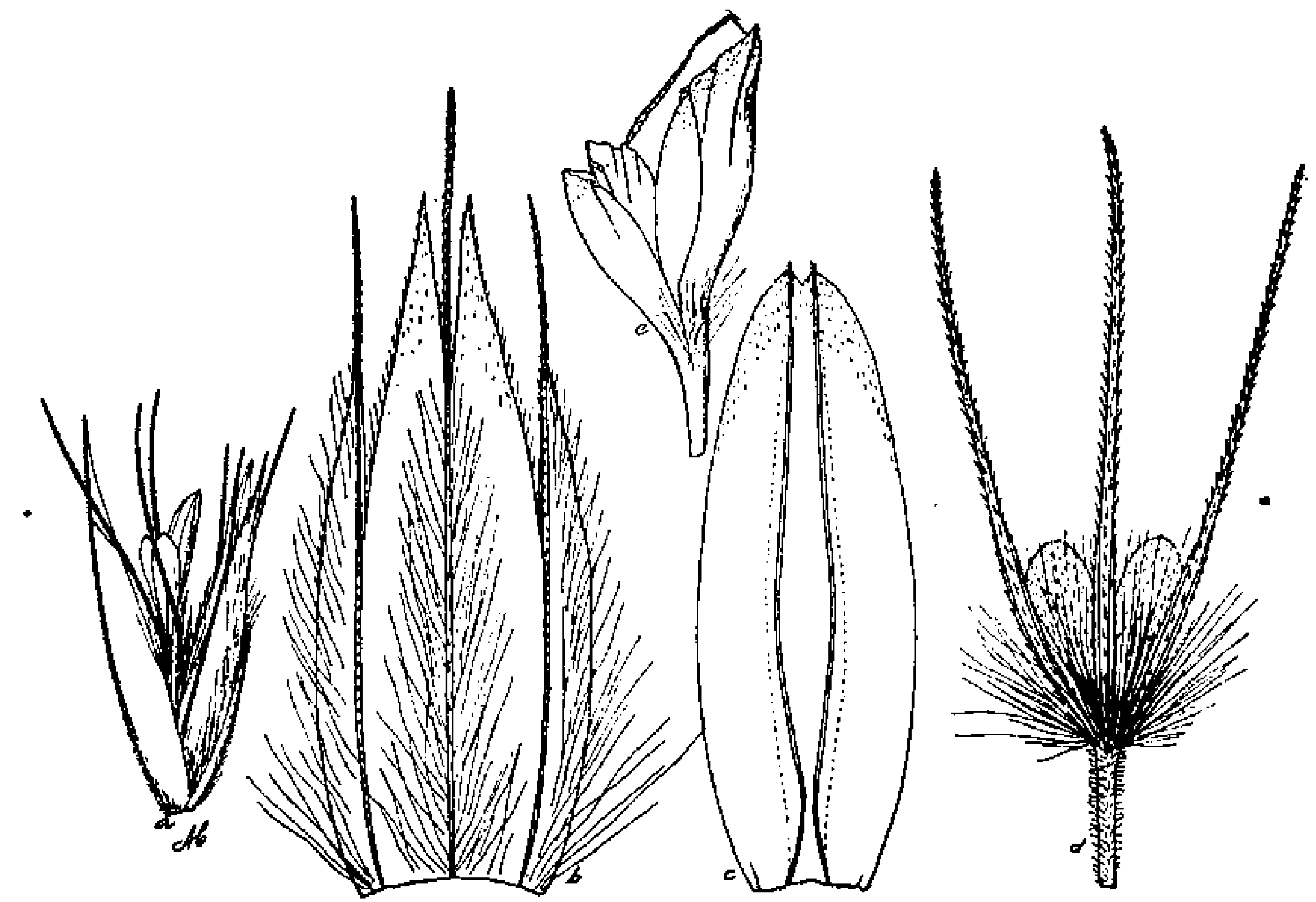

FiG. 35.-Bouteloua oracilis. $a$, spikelet; $b, c$, lemma and palet of first foret; $d, e$, ndiments of second and third florets. $a$, scale $7.5 ; b-e$, scale 15 . From type specimen of $B$, stricla.

not at all uncommon to find plants there 60 or $70 \mathrm{~cm}$. high, while upon the prairies of the Dakotas the species seldom grows over half as high.

The difference in habit has been assumed by some to indicate a different species, but after atudying the species from North Dakota to Oaxaca and cultivating it several times I am not able to take this view. It must be considered that the prairie form of the Dakotas and Montana occurs not only upon the cold, high prairies of the north, but upon the high tableland of northeastern New Mexico (P1. 72, ), upon the San Francisco highland of northern Arizona, upon the Santa Rita highland of southern Arizona, and in many isolated localities in highland Mexico. This low turf-forming form passes by imperceptible gradations into the tall, robust, strictly bunchy form represented best by the type of $B$. stricta.

Explanation of Plate 72,-A. A growth of Bouteloug gracilis under plajns conditions In northeastern New Mexico. For several years thls locality has been grazed during the winter montbs only. B. A turf of Boulelowa gracilis at an altitude of 5,000 to 6,000 feet. Compare with figure A. This spectes does not form a turt thus far sonth, except at a considerable altitude and under favorable soll and molsture conditions. 
Again, when the northern turf-forming and the southern bunchod form are grown together their habits are more alike. Both will form a turf under proper moisture conditions, and both when cultivated become tall and rank, similar to $B$. stricta (Pl. 69, B).

In the publications of the United States Department of Agriculture this species is usually referred to as "blue grama." The Spaniards of our southwest as well as of Mexico refer to it simply as "grama," which they do not distinguish from similar species.

One of the most valuable characteristics of this species, as well as of some others of the genus, is the short period of development. It is a 60 to 80 day grass. Upon the Dakota prairies it produces fresh feed in late May and matures during the drought of August. In southern Arizona and the highlands of Mexico it starts to grow about the middle of July and matures with the close of the rainy and cooler season of late September and early October. It grows in regions where it is cured by drought and not by frosts, the effect being a dead herbage which retains much of its nutriment, making good dry grazing during the winter season, the value of the grass being proportionate to the dryness of the season. A rain after it has cured much reduces its value.

Shear's no. 813, Knowlton 140 and 141 , Rydberg 3429 , Williams 2143 , Nelson 8307 , Merrill \& Wilcox 447, Ward 47, and Grifths 40 are typical of the prairie and northern Rocky Mountain region. In unsodded regions from Colorado southward except at higher elevations, it assumes more of the characters exhibited by specimens collected by Wilcox at Fort Huachuca, in 1884, Mcarns 2301, Metcalfe 698, Pringle 407, and Tounsend \& Baker 257. Parish Brothers 1528, Herb. Colo. State Agr. College 3534 (distributed by N. Y. Bot. Gard.), Skehan 64, and Nealley from Texas, in 1887, are mostly l-spiked forms, and such forms occur throughout the range of the species. They are to be looked upon as dwarfs. They appear to be very common in the lower Sierras in California, at least they have been collected there a number of times.

There is a very peculiar form of the species in the extreme western portion of northern Texas. It differs from the common form mainly in its hairiness, but it occurs in perfectly circumscribed patches among the other form and can be readily distinguished at some distance. It has been seen twice north of Texline, but has never been collected and has not been detected in any of the collections examined. So far as hairiness is concerned, however, it is almost perfectly matched by a collection by Iindheimer (Herb. Texicana Exsic. no. 731) in the herbarium of the Missouri Botanical Garden. This, however, is the large, robust, southern form which differs in general appearance from the inhabitant of the plains.

\section{HERHARIUM SPECIMENS.}

Arizona: Blumer 1704, Chiricahua. Hitcheock 3656, Patagonia. Chase 5834, Flagstaff. IIough 12, Moki Reservation and Jitule Colorado River. Leiberg 5927, San Francisco Forest Reserve. Grifhths 3369 and 3370 , Santa Rita Forest Reserve; 1863, Dragoon Mountains; 1552, Tucson; 1980, Pearce; 1905, Wilcox; 6 L08, Fort Crittenden. MacDougal 299, Flagstaff. Marns 92\%, Bisbee; 1127, Sun Pedro River; 2301, White Water; 2090, San Iuis Mountains. Jones 4240, Bowie. Lemmon 4641, 4642; northern Arizona, 427, 428. Toumey, Chiricahun Wountains; 20, Santa Catalina Mountains. Wilcox, Fort Iluachuca. Griflihs \& Thornber 225, Santa Rita Mountains; 264, Empire Ranch.

Califorvia: IIall 7589, Santa Ana Gayon. Wilder 744, San Bernardino Mountains. Grinwell 354, San Bernardino Mountains. Abrams 2100, San Bernardino County. Parish Brothers 1528, Bear Valley, San Bernardino Mountains. Lemmon 5445.

Colorado: Chase 5303, Manitou; 5290, Pikes Peak legion; 5393 and 5403, IItrbert Ranch, Las Animas County; 5346, near Starkville. Tidestrom 65a, Hugo. Shear 
858, Alamosa; 813, Huerfano County; 7491, Colorado Springs; 978, Canyon City; 776, Walsenburg; 642, Georgetown. Williams 2143, Floressant; 2127, Colorado Springs. Wolfe 1112, 1113, 1114, Twin Lakes. Baker, Earle \& Tracy 971, Durango. Shear \& Bessey 1419, Yampa. Hitchoock 1728, Pikes Peak; 1701, Garden of Gods. Snow 31a, Estes Park. Vasey, Fort Garland, 1884. Griffiths 3303, Rocky Ford. Holm 584, Gunnison.

Kansas: Hilchcock 3834, Manhattan. Shear 705 and 153, Osborne. Thompson 53, Ulysses; 126, Linville; 31b, Ness County. Norton 909, Riley County.

Minnesota: Moyer 23, Montevideo.

Missouri: Bush 589, 489, Sheffield; 390a, Atchison.

Montana: Williams \& Grifiths 219, Billings. Griffiths \& Lange 310, Chateau; 297, Du Puyer; 231, Mission Holy Family. Rydberg 3429, Judith River; 2179 and 2290, Manhattan. Scribner 377, Teton River; 2104, Melrose. Williams 305, Great Falls. Shear 409, Manhattan; 351, Melrose.

Nebraska: Rydberg 1574, Plummer Ford; 2012, Central City; 1803, Hooker County. Clements 2737, Pishelville.

New Mexico: Wooton \& Standley 3524, White Mountains. Hitchcock 3781, Organ Mountains. Metcalfe 1308, Kingston; 698, Bear Mountains. Standley 4404, Holy Ghost Creek; 4911, San Miguel County; 3524, White Mountains. Fisher 26, Torrence. Wooton 206, Lincoln County; 2962, Kennedy; 1097, Organ Mountains. Mearns 2331, Dog Mountains; 2510, Animas Valley. Tracy 8199, Carlsbad. Wright 2023. Fendler 947, 948. Skehan 64, Gray. A. A.\& E. G. Heller 3779, Santa Fe. Earle 64, Gray.

North Dakota: Brannon 104, Minot.

Orlahoma: Ward 47, Carville. Bush 787, Sapulpa.

South Da zota: Wilcox 2, Brookings. Griffths 137 and 800, Aberdeen; 26, Pierre; 40 and 767 , Pierre to Huron; 363, Bellfourche; 319, Bixby; 210, Redfield; 746a, near Willow Creek. Wallace 20, White River. Rydberg 1136, Hot Springs.

Texas: Ball 996 and 894, Chillicothe. Jermy, Bexar County. Hopkins, Jeff Davis County. Nealley of 1887 (dwarf).

UTAH: Tidestrom 2854, Beaver. Garret 2541, Fish Creek Canyon. Ward 419. Jones 5647, Thurber; 5972a, Marysvale; 6002, Panguitch Lake; 5204, Cedar City. Ward 419 and 743 , Rabbit Valley.

Wyoming: Chase 5237, Sundance; 5259 and 5260, Fort McKinney. Rose 472, Clark. Knowlton 1404 and 141, Lance Creek. Merrill \& Wilcox 447, Laramie. A. Nelson 8349, Cassa; 8447, New Castle; 8295, Torrington; 8307, Fort Laramie; 2677, Continental Valley; 7441, Albany County; 3619, 3658, and 3909, Laramie County. E. Nelson 438, Laramie River; 438, Albany County. Griffths 972, Beulah; 507, Bear Lodge Mountains; 297, White IIorse Camp; 698, New Castle; 526, Devils Tower; 501, Sundance. Merrill 2 and 3, Laramie. Williams 2588, Sundance.

Canada: Macoun 2155, Northwest Territory; 13057, Assiniboia; 13035, Manitoba; 30043, Winnipeg; 30045, Assiniboia. Hitchoock 4979, Calgary; 4952, Alberta. Macoun \& Herriot 72934, Saskatchewan; 72935, Alberta.

Mexico: Pringle 407, Chihuahua. Schaffner 132, San Luis Potosi; 1015, San Rafael. Wilkinson 63, Santa Eulalia Plains, Chihuahua. Schumann 1723, Parral. Palmer 24, Chihuahua; 545, Durango; 403 and 399, Saltillo. Bourgeau 448, Santa Fe. Townsend \& Baker 257, Colonia Garcia. Mearns 1658, San José Mountains. Parry \& Palmer 944, San Luis Potoe1. Lloyd 242, Pico de Tierra, Zacatecas. Nelson 6330, Casas Grandes, Chihuahua. Rose \& Painter 6710, Hidalgo.

\section{Bouteloua breviseta Vasey.}

Bouteloua breviseta Vasey, Contr. Nat. Herb. $1: 58.1890$. The type is C. G. Nealley's no. 669, from Screw Bean, Presidio County, Texas, September, 1889. See also U. S. Dept. Agr. Div. Agroat. Bull. 7 : 219, f. 201, 1897. 


\section{DESCRIPTION.}

A stout, rigid, erect perennial, 25 to $40 \mathrm{~cm}$. high, with branching, perennial culms, the internodes, when protected, covered with a thick, scaly bloom, cespitose, spreading by short, stout, scaly rootstocks; sheaths rather close, striate, covering nearly the entire internode; ligule sparingly ciliate-hairy; blades small, 3 to $6 \mathrm{~cm}$. long, convolute, narrow, rigid, acuminate-pointed, bearing a few scattered hairs on the upper surface; spikes normally 2 , often 1 and less frequently 3 , linear-oblong, 2 to $2.5 \mathrm{~cm}$. long, straight or slightly rocurved; spikelets numerous, 30 to 45 , pectinately arranged, about $3 \mathrm{~mm}$. long, consisting of a lower perfect floret and a rudiment, with often a very small secohd rudiment; first glume 2 to $2.5 \mathrm{~mm}$, the second 3 to $3.5 \mathrm{~mm}$. long, nearly smooth; lemma about $5 \mathrm{~mm}$. long, having 4 teeth and 3 awns of nearly equal length, pubescent; palet smooth, awnless, rudiment about $4.5 \mathrm{~mm}$. long, of 3 hispid awns of about equal length and a rudimentary scale, all arising from a tuft of long, white hairs at apex of a stipe. (Figure 36.)

This is a very interesting species, apparently confined to the calcareous soils of the Rio Grande Valley and its tributaries. It is one of the important grasses upon the

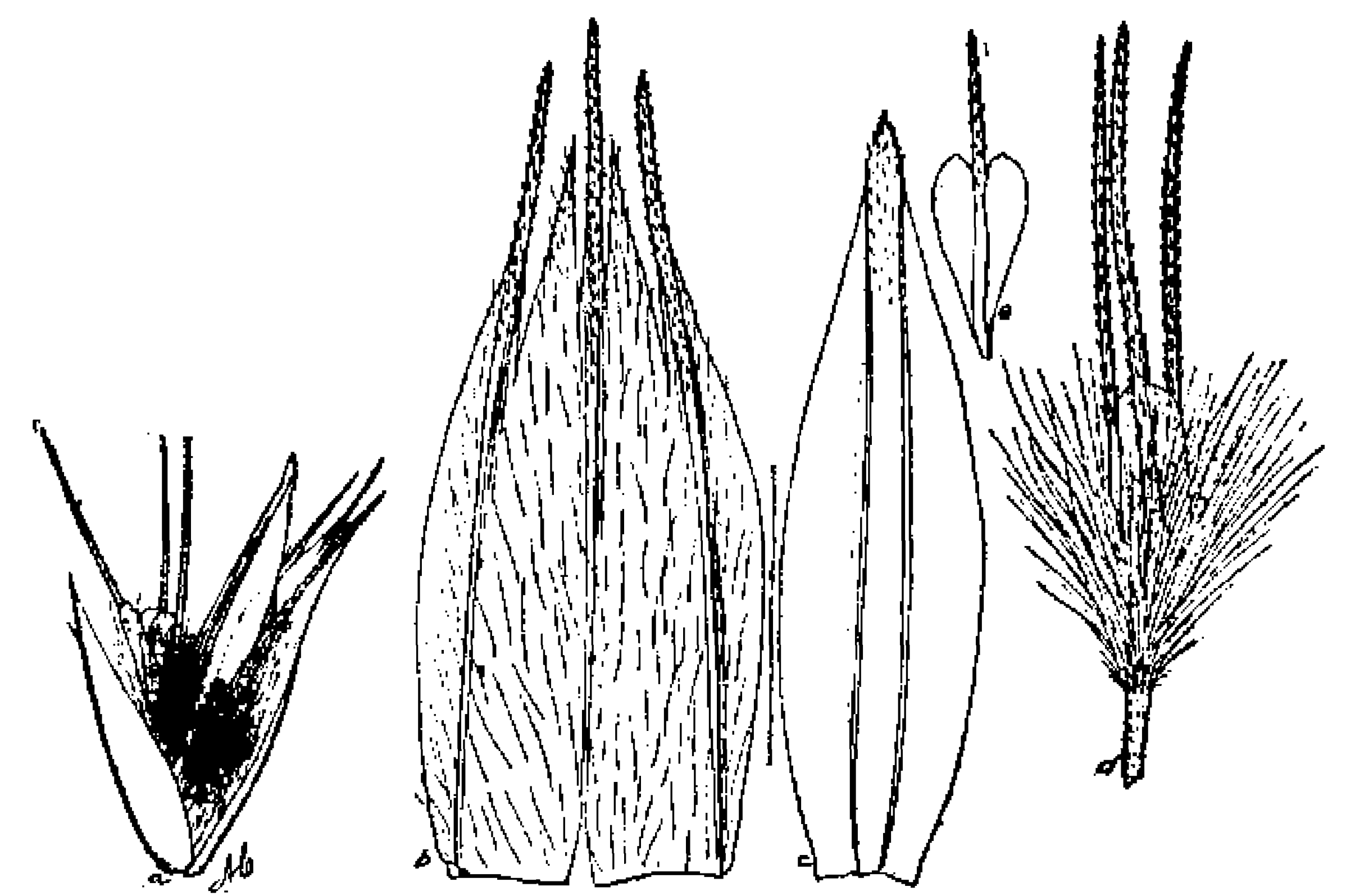

Flg. 36.-Bouteloua breviseta. $a$, Spikelet; $b, c$, lemma and palet of flrst floret; $c, d$, rudiments of second and third florets. $a$, Scale $7.5 ; b-d$, scale 15 . From Nealley 669.

white (gypsum) sands of southeastern New Mexico, where it often creeps into rather unatable earths. Good stands of the grass occur in the Pecos Valley upon soila containing 73.2 per cent calcium sulphate and 3.2 per cent calcium carbonate, according to the analysis of a sample collected in 1903 and submitted early in 1904 to the Bureau of Soils of the Department of Agriculture. In the Roswell district of New Mexico $B$. breviseta is very evidently confined to the gypsum deposits and is popularly known as "gyp" grass. It is a tough, wiry species, but is nevertheless utilized to a very large extent as a pasture grass. The amount of trampling which it endures is remarkable. The deposits of gypsum occur here between the water in and along the Pecos and the better grazing grounds upon the mesas beyond the bluffs. Because of this the trampling across this deposit is very heavy. The tenacious character of the grass is strikingly exhibited in the regions of heaviest traveling. Ifaving perennial culms it is of particular service during a prolonged drought.

There are a number of specimens in the National Herbarium which correspond exactly with the type. IIavard, western Texas, 1881; Nealley 785; Wooton 64 Otero County, New Mexico; and Bailey 340, Boquillas, Texas, are representative. 


\section{Bouteloua ramosa Scribn.}

Bouteloua ramosa Scribn.; Vasey. U. S. Dept. Agr. Div. Bot. Bull. $12^{1}$ : pl. 44. 1890. No specimen is cited in the original description. Beal $a$ cites Nealley's specimen from southwestern Texas. It is impossible now to locate the plant from which Vasey drew up the description. However, it is certain that it was a Nealley specimen, as Beal suggests. At any rate Vasey's figures leave no doubt as to the species, and there are several Nealley specimens of this species in the National Herbarium. See also U. S. Dept. Agr. Div. Agrost. Bull. $7: 218 . f .200 .1897$.

Bouteloua oligostachya ramosa Scribn.; Beal, Grasses N. Amer. $2: 418$. 1896. Reference is made by Beal to the U.S. Dept. Agr. Div. Bot. Bull. $12^{1}: p l .44 .1890$, for this and $B$. ramosa (which see), but he cites Pringle 414 from Mexico under this variety. The same thing is referred to in each case and the inclusion of it in two places is evidently due to an oversight in editing. Palmer 1358 and Pringle 414 are also typical of the species.

The floral details of this species differ in no way from those of $B$. breviseta, but the habit is quite different. The culms, while of the same general half-perennial character and freely branched, are more spread ing and invariably geniculate. The species grows on rough, stony, limy soils, from the lower Rio Grande region southward.

It is more than probable that further study will prove this to be really a form of $B$. breviseta, but there is not at the present time sufficient evidence available in collections to warrant making euch a disposition formally.

\section{HERBARIUM SPECIMENS.}

Texas: Nealley 108, Presidio County; Chende Mountains; Preeidio County; 1081, Sanderaon, Pecos County. Bailey 340 , Boquillas.

MexIco: Pringle 414, Chihuahua. Wilkinson 346, Santa Eulalia Mountains, Palmer 1358, Monclora; 404, Saltillo. Rose \& Painter 7729, Aguascalientes.

\section{Bouteloua parryi (Fourn.).}

Chondrosium parryi Fourn. Mex. Pl. 2:150. 1881. Fournier cites as the type of this apecies Parry and Palmer 9231, but this is evidently a misprint for $943 \frac{1}{2} .^{b}$

Bouteloua polystachya vestita Wats. Proc. Amer. Acad. 18: 177. 1883. PaImer 1357 Sierra Madre, Nuevo León, Mexico, August, 1880, in the Gray, Herbarium, is the type. Parry and Palmer's no. 943, cited by Watson is also in the National Herbarium.

Bouteloua vestita Scribn. in Dewey, Contr. Nat. Herb. 2: 531. 1894. Presumably based on $B$. polystachya vestita Wats. since Watson is cited in paren theses, but no synonyms are given. See also U. S. Dept. Agr. Div. Agrost. Bull. 7 : 220. f. 20\%. 1897.

\section{DESCRIPTION.}

A woolly-pubescent, short-lived perennial, erect or reclining, the geniculate culms being simple or branched, cespitose or, when growing thickly, the individual culms scattering; sheaths loose, striate, pubescent, the ligule reduced to a ciliate-hairy line, with hairs a little more prominent than those on the edges of the sheaths; blades pubeecent with long, scattered, minutely papillose hairs, 2 to $3 \mathrm{~mm}$. long; spikes 4 to 8 , usually 5 or 6 , bilateral, but the black peduncle so curved as usually to make them appear unilateral, 2.5 to $3.5 \mathrm{~cm}$. long; spikelets 40 to 65 , pectinate, upon a slender, papillose-hairy rachis, consisting of a lower fertile floret and one or more upper rudiments; glumes keeled, the first smooth or sparingly pubescent at base, about $2 \mathrm{~mm}$. long, with a short awn, the second woolly, with minutely papillose hairs, 3 or 4 $\mathrm{mm}$. long, with minutely scabrous awn about $0.7 \mathrm{~mm}$. long; lemma 3 to $4 \mathrm{~mm}$. long, 
densely pubescent, 4-toothed, with 3 scabrous equal a wne, about $2 \mathrm{~mm}$. long; palet 4-toothed, 2-awned, pubescent on the edges only, about $2.5 \mathrm{~mm}$. long; rudiment consisting of 3 scabrous, equal awns, about $4 \mathrm{~mm}$. long, together with two or three small acales upon a stipe about $1 \mathrm{~mm}$. long, bearing a tuit of long hairs at each end; caryopsis obovate, pointed at both ends, about $1.3 \mathrm{~mm}$. long, less than $0.5 \mathrm{~mm}$. wide, the scutellum covering nearly the entire ventral surface, the dorsal surface convex. (Plate 73, A. Froure 37.)

The specimens cited in the original description are undersized and can scarcely be called cespitose. They differ, therefore, very decidedly from the large specimens of the Sinta Rita Mountains. They also differ decidedly in color, my speci-

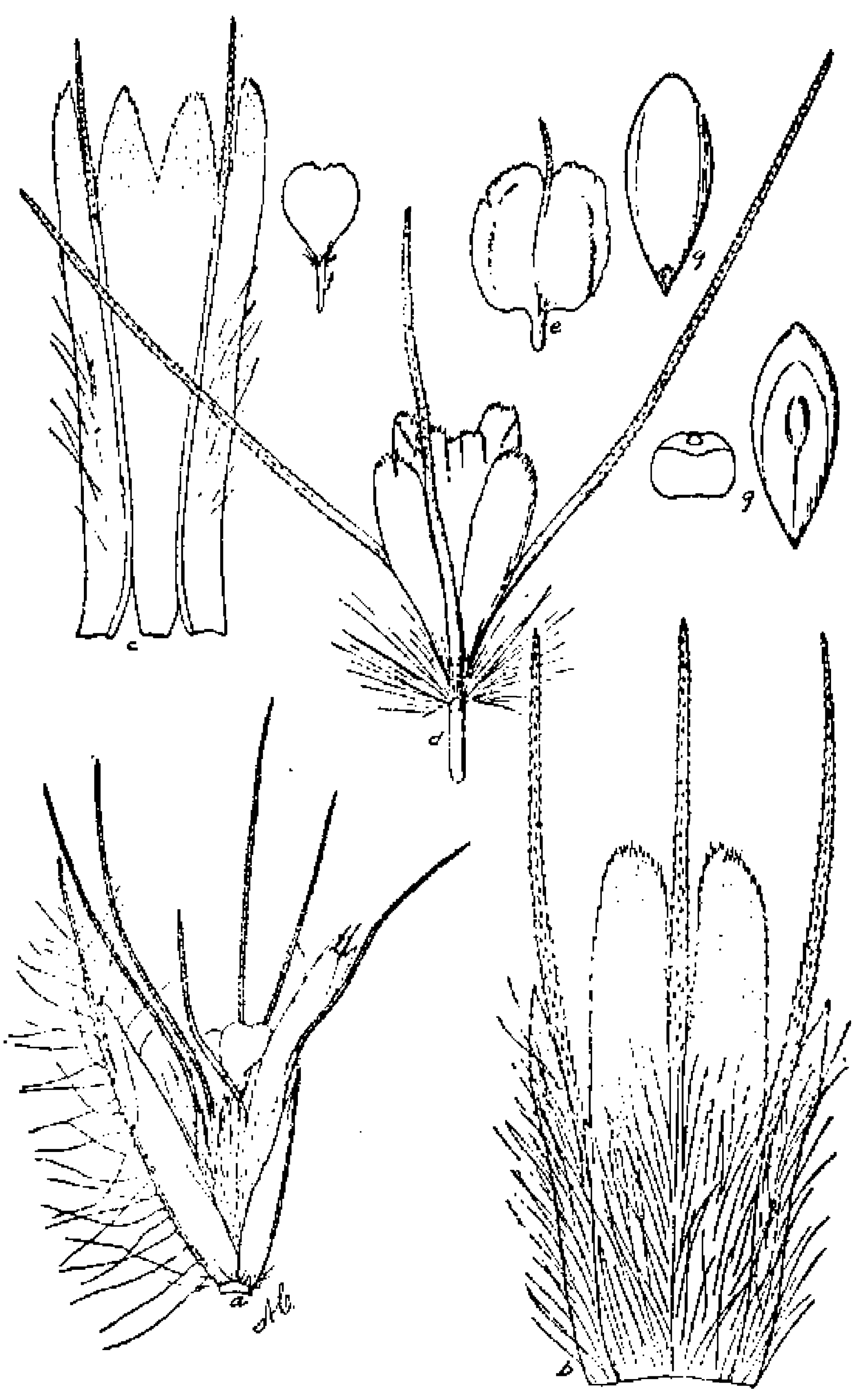

Fia. 3i.-Bouteloua parryi. a, Spikelet; $b$, $c$, lemma and palet of first floret; $d-f$, nudimentary second, third, and fourth florets; $g$, two views and cross section of caryopsis. $a$, Scale $7.5 ; b-0$, scale 12.5 . a - l, From Griffths 7277; $y$, froin Wooton 3065 . mens from southern Arizona being much lighter. Wooton's no. 6033 is especially dark colored, but this is easily accounted for by the abnormal rainfall of the eason in which it was collected. The rains appeared very late that year and continued into the cool season. Grasses often show this excessive coloration when subjected to cooler nights than normal, either when growing later in season than usual or at high altitudes. The type specimens are so diminutive that they are really not at all representative of the species as it is commonly found. Pringle 413, Nealley 265, Lemmon 4638 , well represent the common form of this species.

HERBARIUM SPECIMENS.

Arizona: Meams 11211, San Pedro River, Mexican Boundary Line. Nealley 265, Oracle. Lemmon 426 and 4638, "S. E. Arizona." Griffiths \& Thornber 206, Santa Rita Mountains. Griffiths 1819, 3415, Mescal.

New Mexico: Cockerell 16, Jarilla Junction.

Texas: Scribner in 1887.

Mexico: Schaffner 1019 and 157, San Luis Potosí. Pringle 413, Chihuahua. Wilkinson,

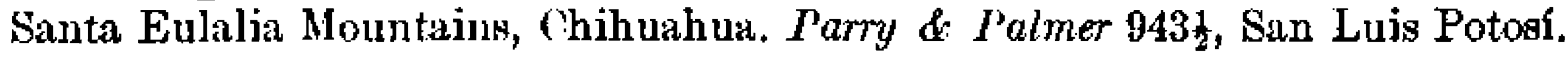

\section{Bouteloua barbata Lag.}

Bouteloua barbata Iag. Var. Cienc. $2^{4}: 141$. 1805. This name has dropped out of reeent literature, although it was correctly interpreted by Ruprecht, Roemer and

Explanation of PLate 73.-A. A clump of Boulcloua parryi consisting of several plants with those. around removed. In situntions like this, whero many plants are found together, the habit is different from that wherein it grows in more isolsted scattered bunches. B. An unusually large isolated tuft of Bouteloua barbata, Adamana, Arizona. 


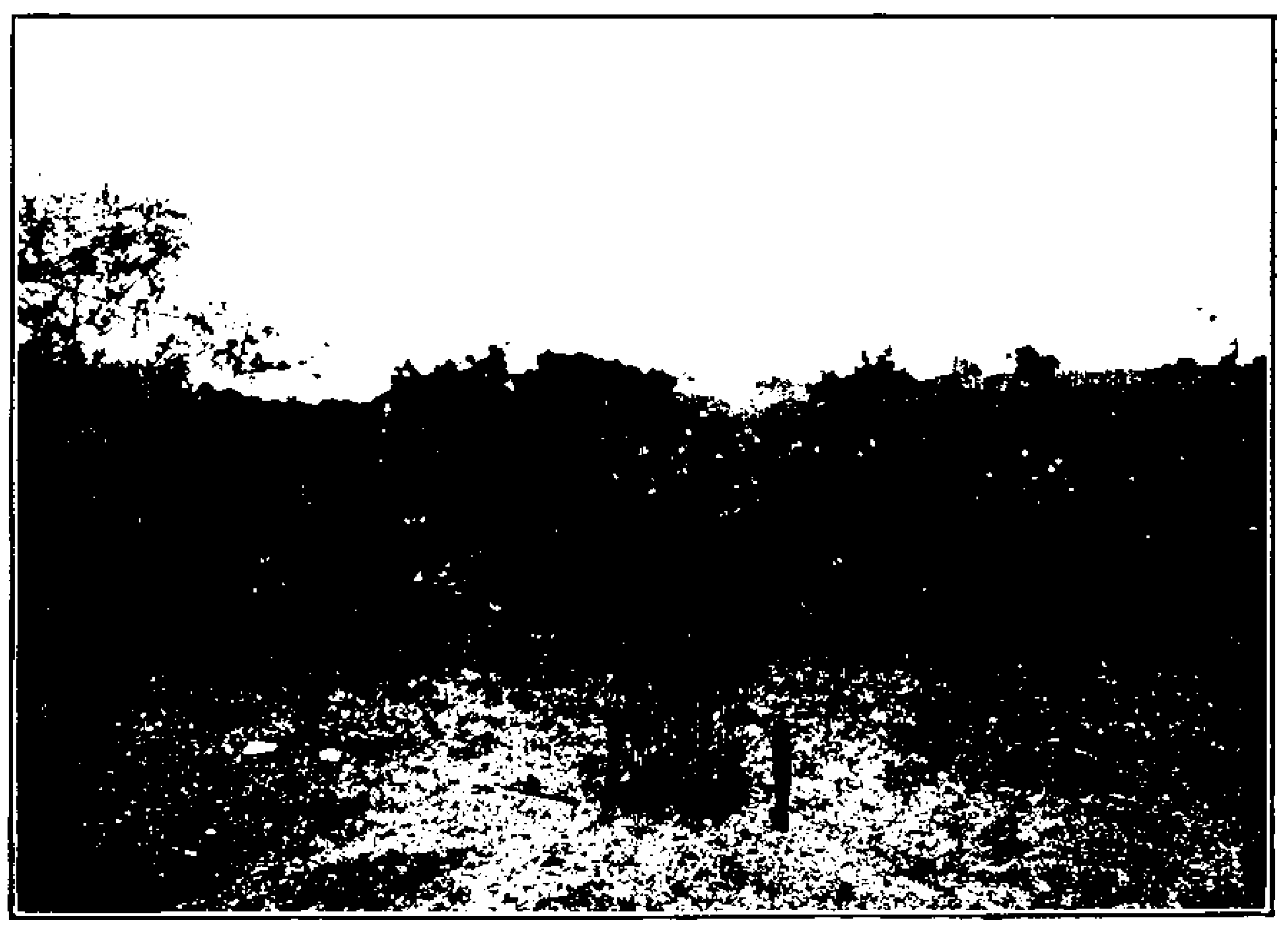

A. Large Plant of Bouteloua parry i Fourn.) Griffiths.

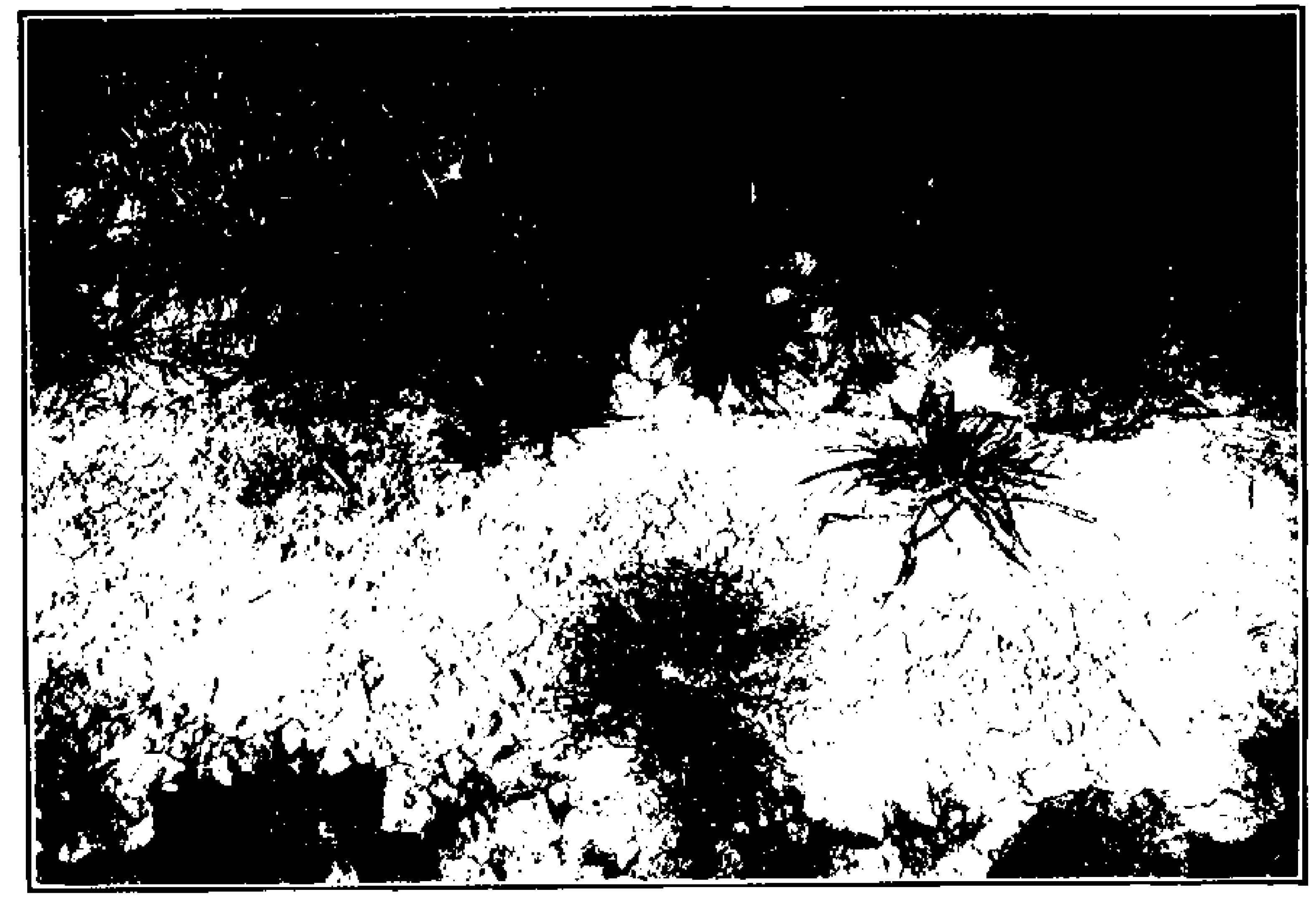

B. bouteloua barbata lag. 
Schultes, Kunth, and Steudel. A plant in the herbarium of the Botanic Garden at Madrid bearing this name in Lagasca's hand, is what in this country we have been calling $B$. polystachya. Of course this specimen is not the type, for Lagasca's first herbarium was burned, but this specimen named by him and his description, so far as it goes, applying to $B$. polystachya, leaves no doubt in my mind about the identity of the species.

Actinochloa barbata Roem. \& Schult. Syst. Veg. 2 : 420. 1817. Based upon Bouteloua barbata Lag.

Eutriana? barbata Kunth, Rév. Gram. 1 : 96. 1829. Based upon Bouteloua barbata Lag.

Chondrosium polystachyum Benth. Bot. Voy. Sulph. 56. 1844. Through the kindness of the authorities at the Royal Botanic Gardens at $\mathrm{Kew}$, I have been able to examine a liberal specimen of the type (Barclay, Magdalena Bay, Lower California). A specimen of the same collection is in the National Herbarium. Attention should be called to the fact that this is a very different species from the Palmer specimen $a$ from the Yaqui River region of Sonora, collected in 1869, aaid by Munro to be "typical."

Bouteloua polystachya Torr. U. S. Rep. Expl. Mise. Pacif. 5²: 366. pl. 10. 1857. Based upon Chondrosium polystachyum Benth.

Bouteloua pumila Buckl. Proc. Acad. Phila. 1863: 93. 1863. The type (Wright 754, Texas) is in the herbarium of the Philadelphia Academy.

Chrondrosium exile Fourn. Mex. P1. $2: 137.1881$. The type (Berlandier 842 ) in the Paris Herbarium is Bouteloua barbata. It is referred there to the genus Chloris and credited to Fournier, but so far as I know was never published in that genus. The specimen is a narrow-spiked, shortawned form. The same number in the Vienna Herbarium is the same species and is named "Bouteloua barbata Rupr."

Chondrosium microstachyum Fourn. Mex. Pl. 2: 138. 1881. The type (Bourgeau
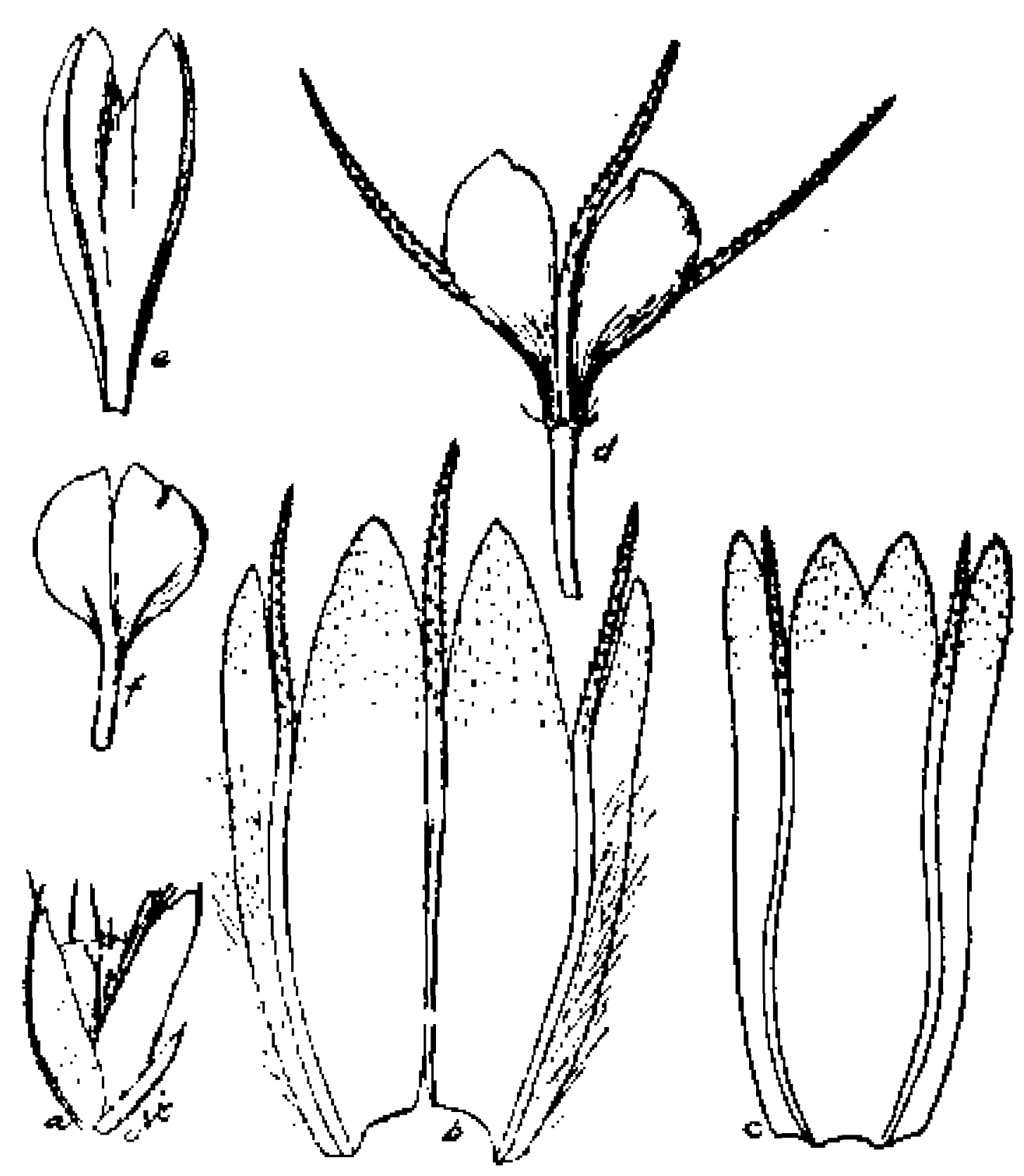

Fic. 34.-Bouteloug barbata. a, Spikelet; $b, c$, lemms and palet of first floret; $d, e$, rudimentary lemna and palet of second floret; $f$, rudiment of third floret, $a$, Scale $7.5 ; b-f$, scale 20 . From ty pe specimen of $B$. pumila.

667) is in the Paris Herbarium. Specimens of the same collection are also in the herbarium of the St. Petersburg Botanical Garden and in the National Herbarium, the former being labeled $B$. oligostachya.

Bouteloua microstachya Dewey, Contr. Nat. Herb. 2: 531. 1894. Based on Chondrosium mirrostachyum Fourn. Dewey considers $B$. arenosa Vasey and $B$. polystachya Benth. as in part synonymous with this.

\section{DESCRIPTION.}

Plants exceedingly variable in both size and general aspect, erect when growing thickly, but prostrate when scattered, in favorable situations as much as $30 \mathrm{~cm}$, high (as in Griffiths 6095) or prostrate, the tuft covering 3 or 4 square feet of surface, or consisting of aingle culms not over $3 \mathrm{~cm}$. long; culms geniculate and freely branching when luxuriant, but mostly simple, especially if on sterile soil; sheaths loose, striate, emooth, comparatively short; blades short, flat, commonly 1 to $4 \mathrm{~cm}$. long, divergent, 
the ligule a ciliate, hairy ring; spikes 4 to 6 or $7,1.5 \mathrm{~cm}$. long; spikelets 25 to 40 , about $3 \mathrm{~mm}$. long over all, consisting of a floret and a rudiment; glumes hispid-keeled, short-awned, the awn subtended on either side by short, lanceolate-pointed teeth of the lamina of the glume, the first $2 \mathrm{~mm}$., the second $3 \mathrm{~mm}$. long; lemma 3.5 to $4 \mathrm{~mm}$. long, densely hairy, having 3 equal, hispid awns, with 2 comparatively large, laminar teeth between them and a smaller one at either side; palet $3 \mathrm{~mm}$. long, 2-awned and 4-toothed, bearing a few scattered hairs on the outside of the nerves; caryopsis oval, about $1 \mathrm{~mm}$. long or less, rounded or slightly flattened on the back, the ventral surface nearly covered by the scutellum. (Plate 73, B, facing p. 382 . Fraures 38, 39.)

The species is variable, eometimes growing a foot high and sometimes only an inch (see plate), its size depending upon the character of the soil and the amount of rain-

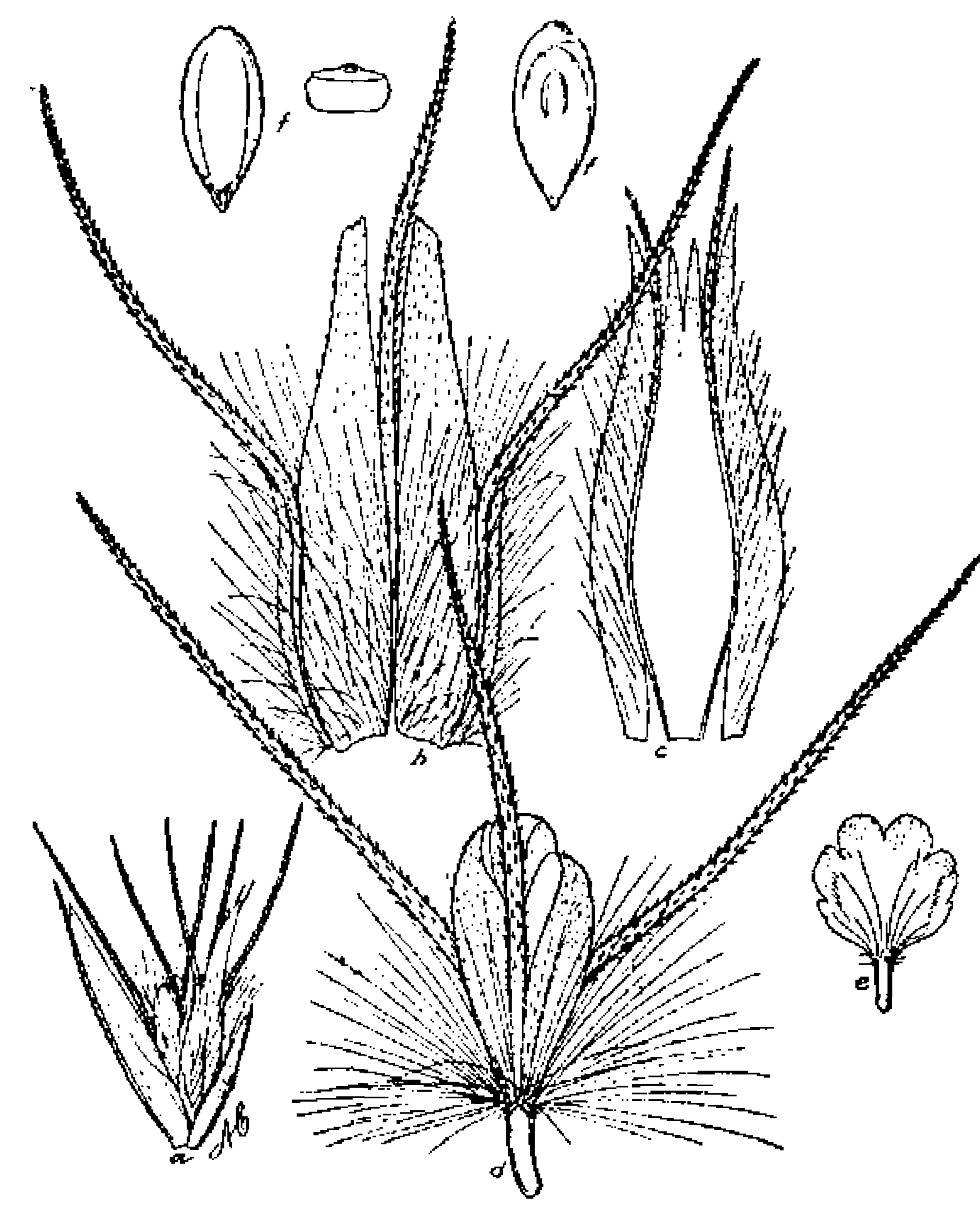

FtG. 30.-Boulclota barbata. $a$, Spikelet; $b, c$, lemme and palet of first floret; $d, c$, rudimentary second and third florets $y$, two views and cross section of caryopsis. $a$, Scale $7.5 ; b-f$, seale 15 . From Griffths 6095 .

fall. In our Southwestern States and in Mexico east of the Pacific coast region it has two quite distinct forms, one with short awns, the other with long awns, making the spike much wider in the latter case. The long-awned form very closely approaches $B$. arenosa of the Pacific coast of Sonora, but that species has still heavier spikes. Further study, however, may require the inclusion of that species here. I do not feel warranted at present in making a change in the nomenclature, for my ficld experience has nat brought me in contact with the arenosa form.

Pringle's 13626, Schaffner 183 and 187, Rothrock 352, Wooton 398, Bourgeau 667, Metcalfe 701, are all typical of this species, al though showing some variation in the length of the awns and in the size of the plants, and consequently a decided difference in general aspect. Two specimens, from Iower California, Brandegee, San Jusé del Cabo, 1890, and Purpus, Cape Region, are doubtfully referred here.

\section{HERRAIIUM SPECIMENS.}

Arizona: Toumey in Seymour's Grasees 85, Tueson. Ilitcheock 3668, Patagonia; 3489, Tucson. Purpus 8203, Reaver Creek. Blumer 1706, Paradise. Mearns 1121, San Pedro River near Mexican boundary; 2765, Quitovaquito. Griffiths 1897, Wilcox; 2009, Benson; 1646, Sulphur Spring V'alley; 1524, Tucson; 3400, Santa Rila Forest Reserve; 3360, Tucson. Knowlton 194, San Francisco Mountains; Lemmon 4644; Davidson 4la, Clifton; Grifiths \& Thormber 254, Santa Rita Mountains. Jones 6063, Buckskin Mountains. Rothrock 352, Cottonwood. MacDougal 571, Fort Verde. Leiberg 5922, Grand Canyon at Bright Angel Trail. 
CaLrfornia: Jones 67a, Needles.

New Mexico: Wooton 2923, north of Chamita; 2023, Las Cruces; 3063, Organ Mountains; 398, Dona Ana County. Metcalfe 701, Silver City; 1395, Black Range. Earle 296, Roswell. Plank 15, Socorro. Lemmon 3147, Holbrook to Albuquerque. Hitchcock 3806, Organ Mountains. Jones 55a; Tracy 8190, Carlsbad. Mearns 2363, Dog Spring, Dog Mountains. Mulford 69, Florida Mountainв.

Nevada: Cooper 2241, Fort Mojave.

Texa8: Palmer 1356, Guadalupe; Tracy 8217, Big Springs; 8207, Fort Worth; Cockerell 15, Fort Bliss. Jones 641, 13a, and 4341, El Paso. Havard in 1882, Eagle Pass. Nealley 103, Laredo.

UTAH: Jones 5702a, Junction; 5696, Cainville; 5652, Capitol Wash. Thompson 339.

Mexico: Brandgee, San José del Cabo, Lower California. Palmer 508, La Paz, Lower California and Guaymas; 857, Carmen Island; 714, Durango; 400 and 401, Saltillo. Schaffner 152 and 1017, San Luis Potosi; 153, Valley of Mexico. Pringle 490, Chihuahua; 11216 and 13626, Jimulco. Barclay, Lower California. Parry \& Palmer 946, San Luis Potosi. Smith 957, San Antonio Valley, Oaxaca. Pittier 470, State of Durango.

\section{Bouteloua arenosa Vasey.}

Bouteloua arenosa Vascy, U.S. Dept. Agr. Div. Bot. Bull. 12 $2^{1}: p l .84 a .1890$. The first use of the name was by Watson, b but no description is given. The type is Palmer 189, Guaymas, Sonora, Mexico, 1887, in the National Herbarium.

\section{DESCRIPTION.}

A tufted, smooth, erect or decumbent annual, with sparingly branched, simple or geniculate culms, 10 to $15 \mathrm{~cm}$. long; sheaths striate, rather loose, especially in branching individuals, the ligule conspicuous, consisting of a white, ciliate fringe 1 to 1.5 $\mathrm{mm}$. long; blades 3 to $4 \mathrm{~cm}$. long, rather sparse in the majority of specimens, but plentiful in others; panicle racemose, 3 to $6 \mathrm{~cm}$. long; spikes 2 to 4 , about $1.5 \mathrm{~cm}$. long, mostly recurved; spikeleta 16 to 20 , pectinate, consisting of a lower perfect floret and an upper rudiment; first glume 1 to $1.7 \mathrm{~mm}$, the second about $3 \mathrm{~mm}$. long, the keels very minutely scabrous, usually 2-toothed with short awns between the teeth; lemma 4-toothed, about $4.5 \mathrm{~mm}$. long including the 3 long, scabrous, equal awns, about $3 \mathrm{~mm}$. long, completely covered on the back with long, white hairs $1 \mathrm{~mm}$. or more in length; palet 4-toothed, $3 \mathrm{~mm}$. long, including the scabrous awns, about $1.3 \mathrm{~mm}$. long, with a white, hairy, ciliate fringe outside of the nerves, the awns being a continuation of these; rudiment $5 \mathrm{~mm}$. long, consisting of three approximately equal, scabrous awns, $3 \mathrm{~mm}$. long, alternating with the obovate lobes of the lemma and supported upon a short, hairy-tufted atipe; caryopsis obovate, $1 \mathrm{~mm}$. long, $0.4 \mathrm{~mm}$. wide, the acutellum covering about two-thirds of the ventral surface. (Figure 40.)

The species is to be looked upon as a long-awned form of $B$. barbata, which appears to be characteristic of the coast of Sonora. Dr. Palmer's notes indicate that the type was collected in loose, kandy soil.

It is quite doubtful in my mind whether $B$. arenosa is really apecifically distinct from $B$, barbata, but $I$ hesitate to reduce it, because my experience in the field in this particular locality is very limited. It must be confessed, however, that there are forms of $B$. barbata in Arizona and New Mexico which approach this in the one character which has served to separate it; that is, the length of the awns. However, only the specimens enumerated below have awns as short as those of $B$. barbata, the A rizona forms referred to $B$. barbata having awns only two-thirds to three-fourthe as long. We have here the same sort of differences that we have in $B$. rothrockii and its allies. 
Besides several sheets of the type collection there are in the National Herbarium two specimens collected by Orcutt in Lower California in 1889 and 1890 and one by Hayes at "Puachio," Arizona, in 1858. All of these differ only in having longer awns from forms of $B$, barbala which I know in the field.

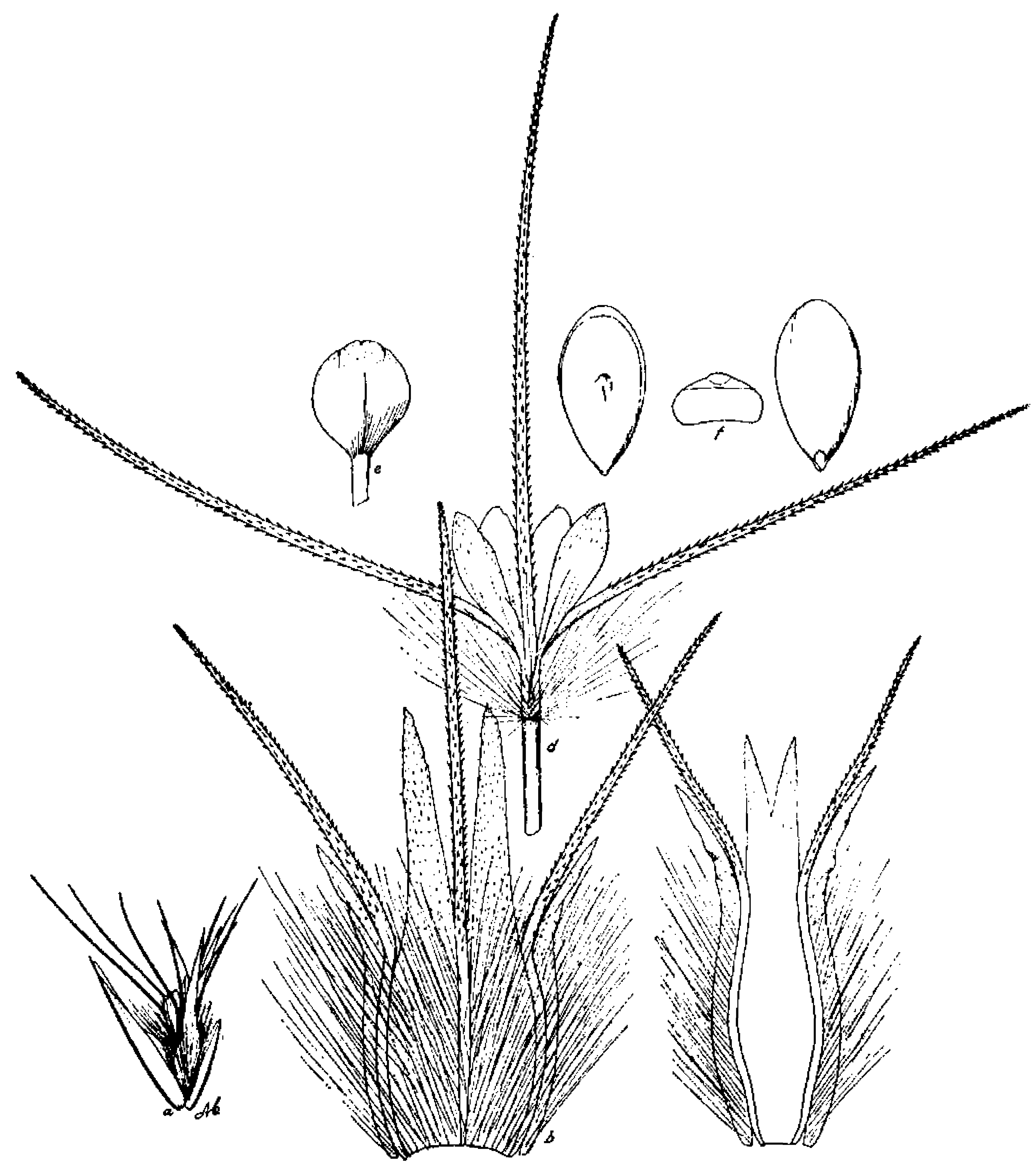

FIG. 40.-Bouthioua arenosa. a, Splkelet; $b, c$, lemma and palct or flrst floret; $d$, $e$, nidimentary second and third florets; $f$, two views and cross section of caryopsis. $a$, Seile $7.5 ; b-f$, scale 20 . From typo specimen.

\section{HERBARIUM SPECIMENS.}

Anizona: Hayes, Puachio. Mearns 929, south of Bisbee. California: Orcutt, Colorado Desert.

Texas: Burkley in 1883.

Mexico: P'almer 189, Guaymas. Hitchcock 35̄34, Hermosillo. Orcutt, Lower California in 1889 . 


\section{Bouteloua trinii (Fourn.).}

Chondrosium trinii Fourn. Mex. Pl. 2 : 136. 1881. A duplicate of the type (Berlandier 1427, Laredo, Texas), in the National Herbarium, and a photograph and fragment of the type from the herbarium of the Paris Museum are before me.

Chondrosium (?) polystachyum Trin.; Fourn. Mex. Pl. 2: 136. 1881. This herbarium name is given as a synonym of Chondrosium trinii.

Bouteloua trifida Thurb. in Wats. Proc. Amer. Acad. 18:177. 1883. The type, in the Gray Herbarium, is Palmer 1355, Monclova, Coahuila, Mexico, 1880. See aleo U. S. Dept. Agr. Div. Bot. Bull. $12^{1}: p l .46 .1890$; L. S. Dept. Agr. Div. Agrost. Bull. 7: 224 and 225. f. 206 and 207. 1897.

Bouteloua burkii Scribn. in Wats. Proc. Amer. Acad. 18: 179. 1883; Bull. Torrey Club 11: 5.1884 . The type, as considered by Scribner in the latter publication, was collected at Laredo, Tex., by Mrs. Anna B. Nickels. This specimen appears to have been destroyed when Scribner's herbarium was burned. Berlandier 167, which is the first specimen cited by Watson, probably was burned at the same time, at least this does not appear to be now in the Gray Herbarium. Berlandier 1427, cited in the original description, is in the National Herbarium, Curtiss $3440^{*}$ also cited, is in the herbarium of the Missouri Botanical Garden and the National Herbarium. See also U. S. Dept. Agr. Div. Bot. Bull. $12^{1}$ : pl. $\$ 6.1890$.

Watson's paper $a$ was published A ugust 23, 1883. Here he describes $B$. trifida Thurb., basing it upon Palmer 1355, Monclova, Coahuila, Mexico. He also lists Parry \& Palmer 945 and $W$ right 749,2020 , and 2022 , and describes $B$. burkii

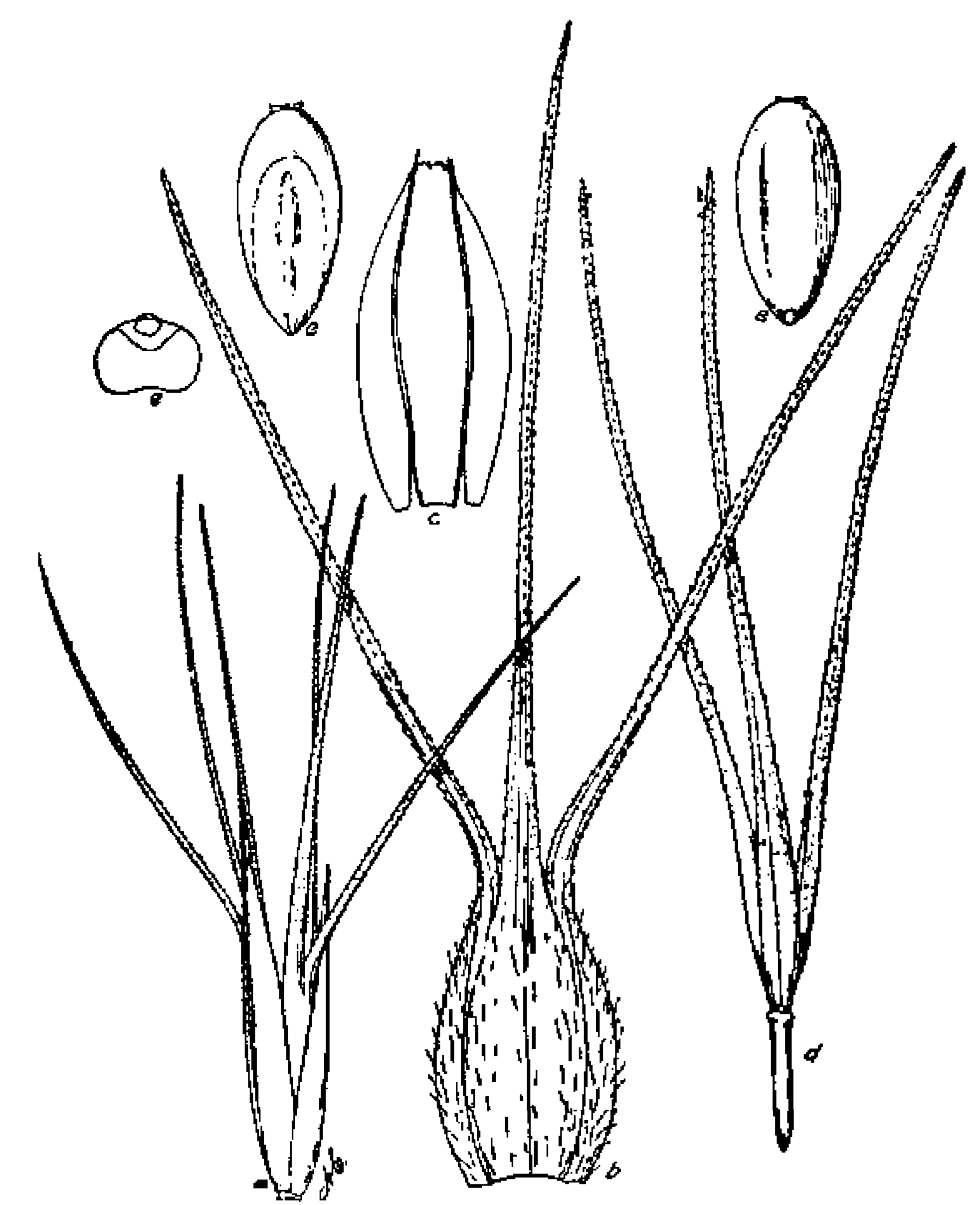

Fia. 41.-Bouteloua trinii. a, Splkelet; $b, c$, lemma and palet of first floret; $d$, rudiment; $e$, two views and cross section of caryopsis. a, Scale 7.5; b-e, scale 12.5. From Griffiths 6104 .

Scribn., basing it upon Berlandier 167 and 1427, and Curtiss 3440 . Scribner $b$ publishes the same species again. Under $B$. trifda Scribner lists: "Texas and New Mexico; G. R. Vasey, Mexico; Dr. E. Palmer No. 1355, 1880." Under B. burkii he lists the following: "Laredo, Texas; Mrs. Anna B. Nickels; communicated to me by Mr. Isaac Burk, of Philadelphia, for whom the species is named. Sandy plains, Upper Concho, West Texas; J. Reverchon; No. 3440*, Curtiss's Distribution North American Plants."

In the National Herbarium a specimen collected by Letterman, Laredo, Tex., July, 1882, is marked the type of $B$. burkii, and another collected by G. R. Vasey, El Paso, Tex., 1881, the type of B. trifida, both in Scribner's hand.

\section{DESCRIPTION.}

A variable, low, delicate, cespitose perennial, with comparatively naked culms, 12 to $15 \mathrm{~cm}$. high, but very variable in size, erect, or, in old, undisturbed plants,

a Proc. Amer. Acad. 18 : 176-180. b Bull. Torrey Club 11: 5. January, 1884. 
geniculate at the very base; sheaths close, striate, smooth or very minutely roughenedhispidulous, with ciliate-fringed ligule and minutely pubescent, hispid blades, bearing a few long, scattered, papillose hairs, divaricate, 1 to $2 \mathrm{~cm}$. (Letterman, Laredo, 1882) to 3 to $7 \mathrm{~cm}$. long (Griffths 6338); panicle racemose, 4 to $7 \mathrm{~cm}$. long, bearing 3 to 7 spikes, 1 to $1.3 \mathrm{~cm}$. long, bearing about 12 pectinately arranged spikelets 7 to $8 \mathrm{~mm}$. long; spikelets consisting of one fertile floret and a rudiment; glumes about equal, smooth, keeled, about $2.5 \mathrm{~mm}$. long; lemma hairy, 4 to $5 \mathrm{~mm}$. long, bearing 3 scabrous awns about $3 \mathrm{~mm}$. long; palet 2-keeled, not awned, about $1.5 \mathrm{~mm}$. long; rudiment consisting of 3 hispid, equal awns, enlarged at base, about $4 \mathrm{~mm}$. long, upon a naked stipe $1 \mathrm{~mm}$. long or less; caryopsis obovate, $0.8 \mathrm{~mm}$. long, $0.3 \mathrm{~mm}$. wide, the scutellum somewhat oval, two-thirda the length of seed. (PLATks 74, $\Lambda ; 78$. Figures 41, 42.)

Like many other species of the genus this is very variable in size and general aspect. The specimens marked type in the National Herbarium, as mentioned above, while not the nomenclatorial types, are nevertheless typical of what was intencled to be published under these two names. For nomenclatorial purposes I consider them as

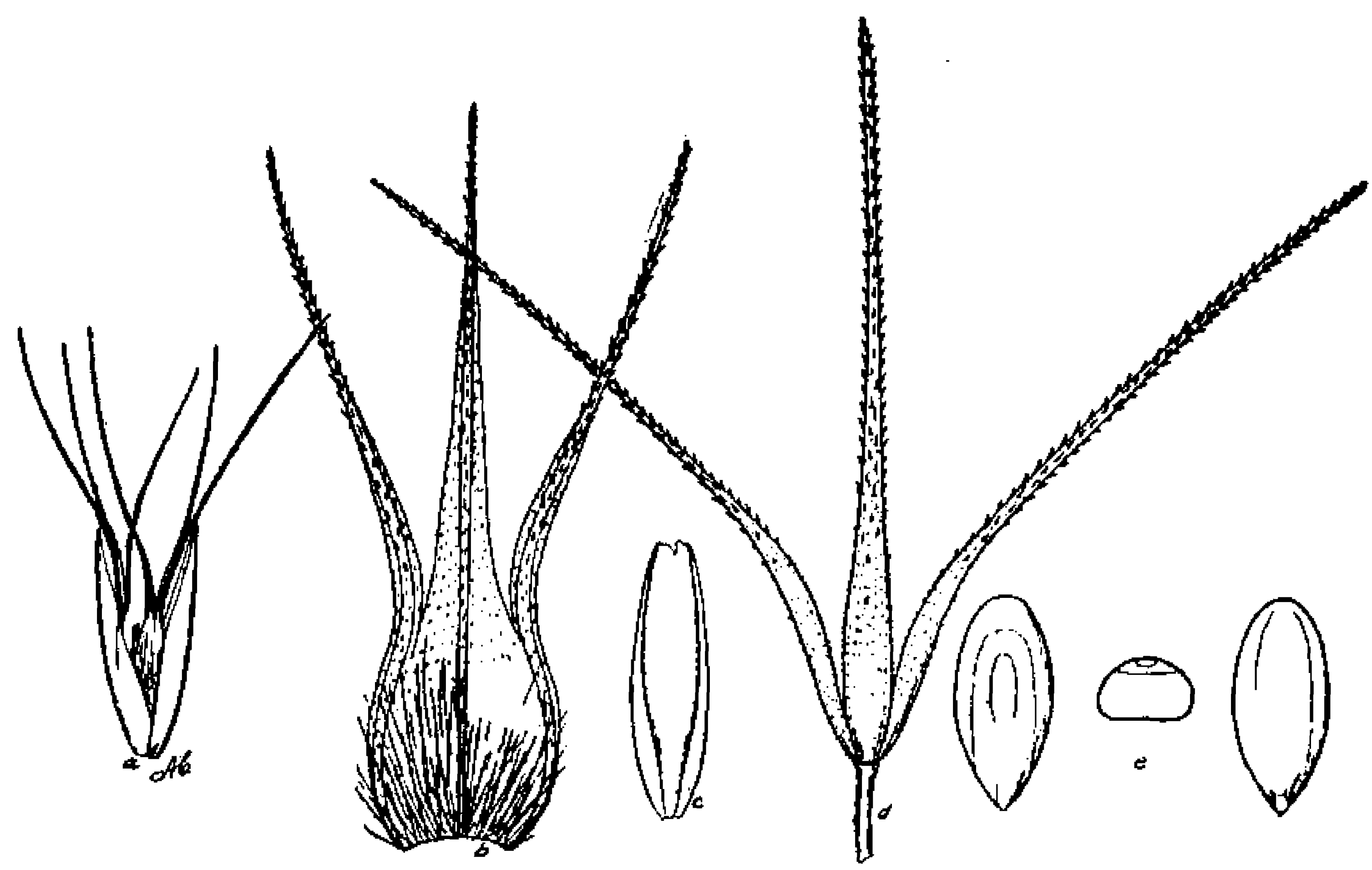

Fia. 42,-Bouteloua trinit. a, Spikelet; $b, c$, lemma and palet of first floret; $d$, rudiment; $e$, two views and cross section of caryopsis. $a$, Scale $7.5 ; b-e$, scale 15 . a-d, from Letterman, Iaredo, Tex. (lypical of B. burlii); $e$, from Griffiths 6338 .

good as types. Bouteloua burkii and Chondrosium trinii are the same form of plant; that is, the shorter awned, more leafy plant, with longer, laxer leafage.

Westward from about the region of Del Rio, Texas, the species is inclined to assume a slightly different aspect. Especially is this true from the region of El Paso to Arizona. The plant is somewhat dwarfed, the leaves are iewer, shorter, and mure rigid, and the awns slightly longer. In short, the same differences occur in this species upon entering more arid situations as are found in $B$. gravilis in southern California where the leaves become more radical, shorter, and more rigit, compared with those of more humid sections.

In the Rio Grande region the species is very important from the stockman's standpoint, for it often constitutes the sum total of the forage upon the alluvial soils of the shallow ravines and also extends onto the rocky knolls and ridges.

When closely grazed it is short, with divaricate, rrowded leaves near the base and comparatively naked culms. When unmolested and consequently somewhat shaded

ExPlanation of Plate 74,-A. Bouleloua trinit as it grows in arid situations near $A$ ndrade, Arizona. Here we always have the form described as B. trifida. B. An extraordinarily large bunch of Bouteloua eriopoda from the Santa Rita Mountains, Arizona. 


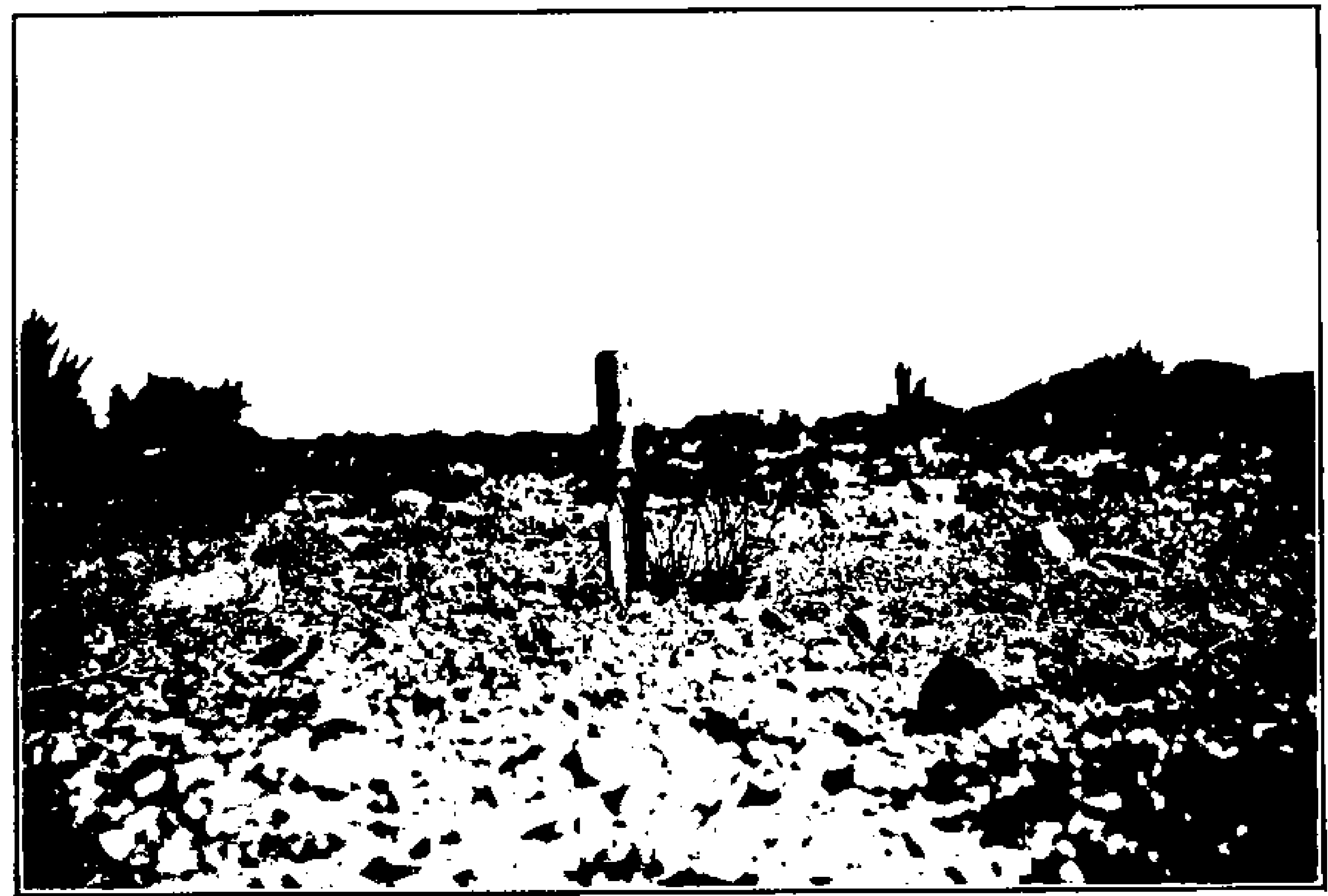

A. Bouteloua trinil 'Fourn.' GRiffiths.

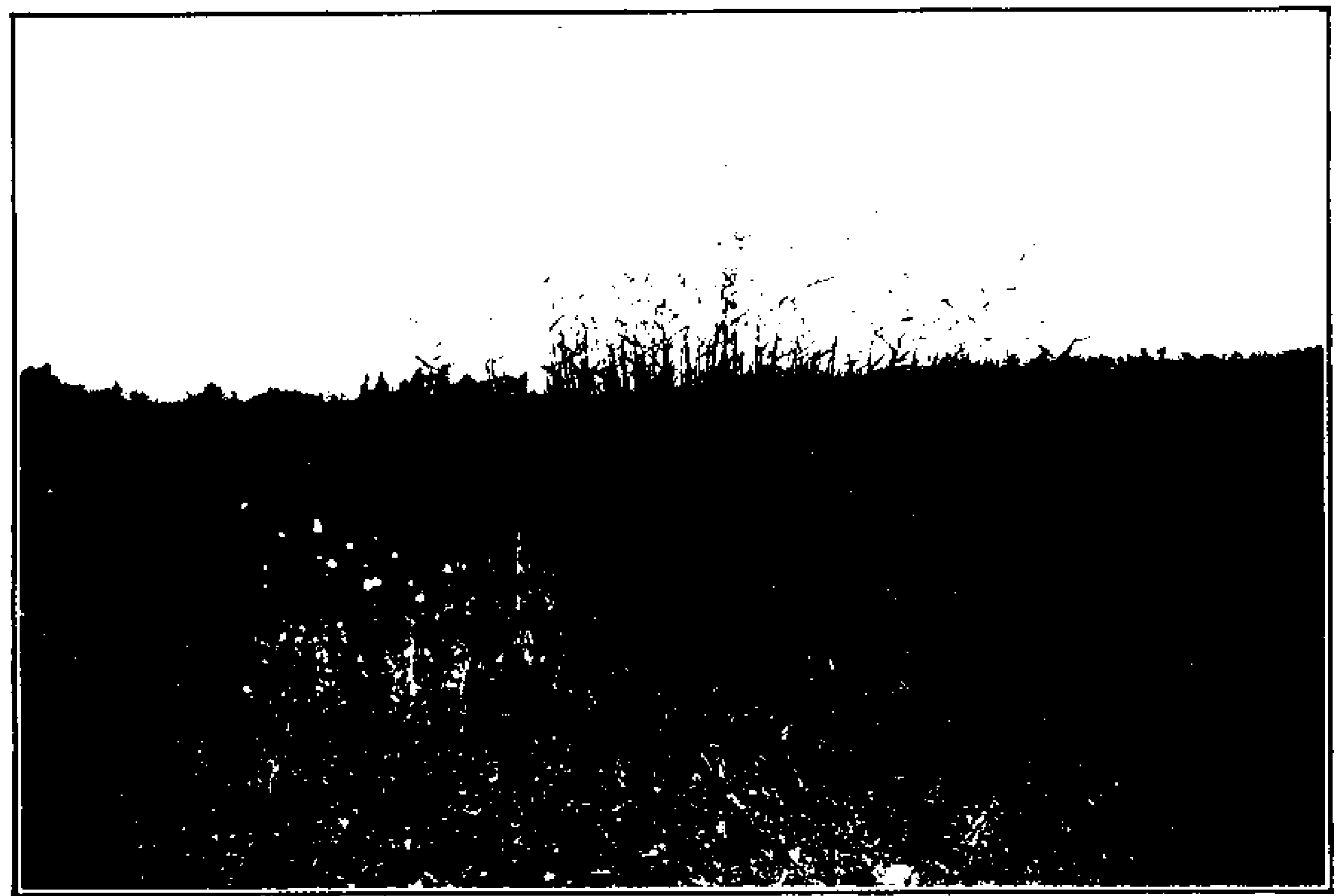

B. Bouteloua ERIOpoda TORR. 
by old growth at its base, the leaves are more lax, ascending, and longer, and the culms are more leafy above.

Specimens are abundant in American herbaria. They are usually referred to $B$. burkii and $B$. trifida in about equal numbers. The range of the species is from the Rio Grande region of Texas southward to San Luis Potosi and westward to Tucson, Arizona.

HERBARIUM SPECIMENS.

The following are typical of $B$. burkii:

Texas: Reverchon 162, Coleman and Tom Green Counties; $1361 \frac{1}{2}$ and $1361, a$ Llano; 1408, Sabinal Canyon; 3440, Lpper Concho, in Curtiss N. Amer. Plants. Jermy, Bexar County. Smith 97, San Diego. Tracy 8230, Colorado; 8896, Kingsville. Nealley, Cotula, 1888. Piper, Kingsville, 1906. Letterman, Laredo, July, 1882. Berlandier 1427.

MexICo: Pringle 1974 and 11735, Monterey; Palmer 370, Victoria.

The following herbarium specimens are typical of $B$, trifia (Pr. 74, A.):

Arizona: Pringle, mesas near Tucson, 1884. Griftith 2448, Tucson.

New Mexico: Wright 2022 of 1851-52.

Texas: Vasey, El Paso, 1881. Reverchon b 1408 (Texas Plants), Sabinal Canyon. Mexico: Palmer 522 and 402, Saltillo.

The following specimens appear to stand midway between the two forms in some characters, usually due to long awns combined with softness and laxity of leafage:

ARIzONA: Lemmon, Hackberry 1889.

Texas: Canby 270, Spofford Junction. Reverchon 37; 361, Llano (Texas Plants); 1408, Sabinal Canyon. Jermy 212, Bexar County. Plank, El Paso, 1894; 1, Llano. Ilavard 30, mouth of Pecos. Mearns 1215, Fort Clark.

Mexico: Pringle 412, Chihuahua. Palmer 552, Victoria; 1355, Monclova. Parry \& Palmer 945, San Luis Potosí. Wilkinson, Santa Eulalia Plains, Chihuahua, 1885. Mearns 1201, La Noria, Sonora.

\section{Bouteloua sonorae sp. nov.}

DESCRIPTION.

A low, spreading, or half-erect perennial, 12 to 15 cm. high; culms simple, stoloniferous or simply geniculate; sheaths close, striate, smooth, the ligule

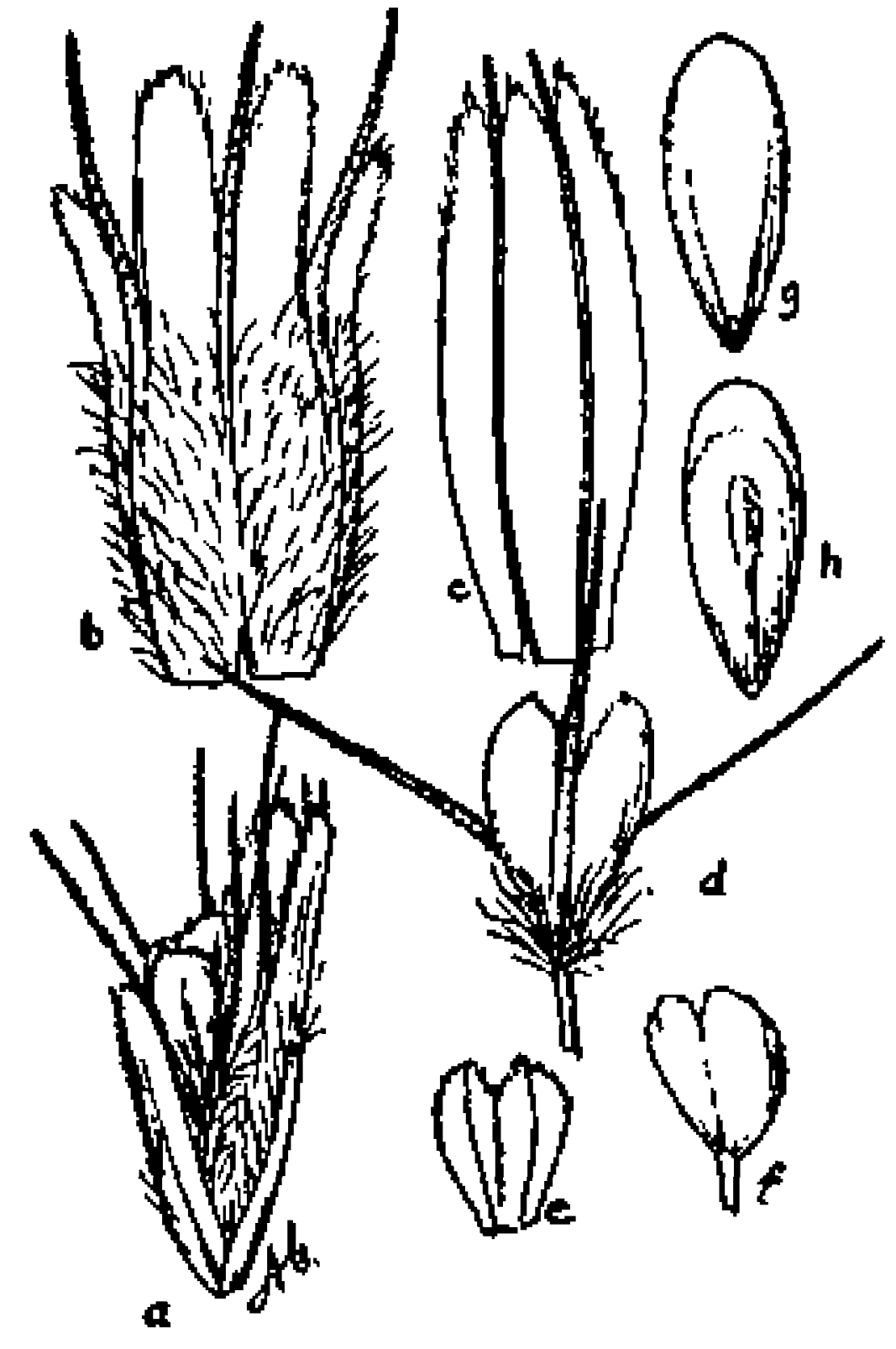

Fig. 43.-Boutelouasonorac. a, Spikelet; $b, c$, lemma and palet of first floret; $d, e$,rudimentary lemma and palet of second floret; $f$, rudiment of third floret; $a, h$, two views of caryopsis, $a$, Scale 7.5; $b-h$, scale 10 . From type specimen. a rather long fringe of white hairs; blades mostly radical, narrow, short, acuminate, 5 to $10 \mathrm{~cm}$. long, decreasing upward to often $1 \mathrm{~cm}$. long, revolute; panicle racemose, about $4 \mathrm{~cm}$. long; spikes 2 to 4 , mostly 4 , about 12 to $14 \mathrm{~mm}$. long, recurved at the apex; spikelets about 30 , pectinate, about $2.5 \mathrm{~mm}$. long, consisting of a lower perfect floret and an upper rudiment; glumes smooth except for a few long white hairs on the keel, not awned, the second $1.5 \mathrm{~mm}$. long, the first a little shorter; lemma hairy, 3-nerved, shortly 3-awned, 2.3 to $2.5 \mathrm{~mm}$. long, including awns; palet concave, shortly 2-awned, a trifle shorter than its lemma; rudiment of 3 awns interspersed with short, blunt scalee upon a short, hairy-tufted stipe, about $0.5 \mathrm{~mm}$. long; caryopsis not seen. (FIGURE 43.)

a Typical $B$. burkii and $B$. trifida are on the same sheet of no. 1361, Texas Plante.

$b$ Three sheets of this are placed in as many groups. 
The species is to be looked upon as a perennial $B$. barbata, a native of the west coast of northern Mexico. The type is Palmer's Yaqui River specimen of 1869 in the National Herbarium. Palmer 75l, Alamos, Mexico, 1890 and $1 \%$. G. Wright 1322 from the headwaters of Mazatlan River are distinclly stoloniferous, while Hitchcock 3552, Guaymas, Mexico, is simply geniculate and a much larger plant than any of the others. The anme is true of Chase 5509 from near Guaymas.

\section{Bouteloua eriopoda (Torr.) Torr.}

Chondrosium eriopodum Torr. in Emory, Mil. Reconn. 154. 1848.

Bouteloua eriopoda Torr. U. S. Rep. Expl. Miss. Pacit. 4: 155. 1856. Based upon

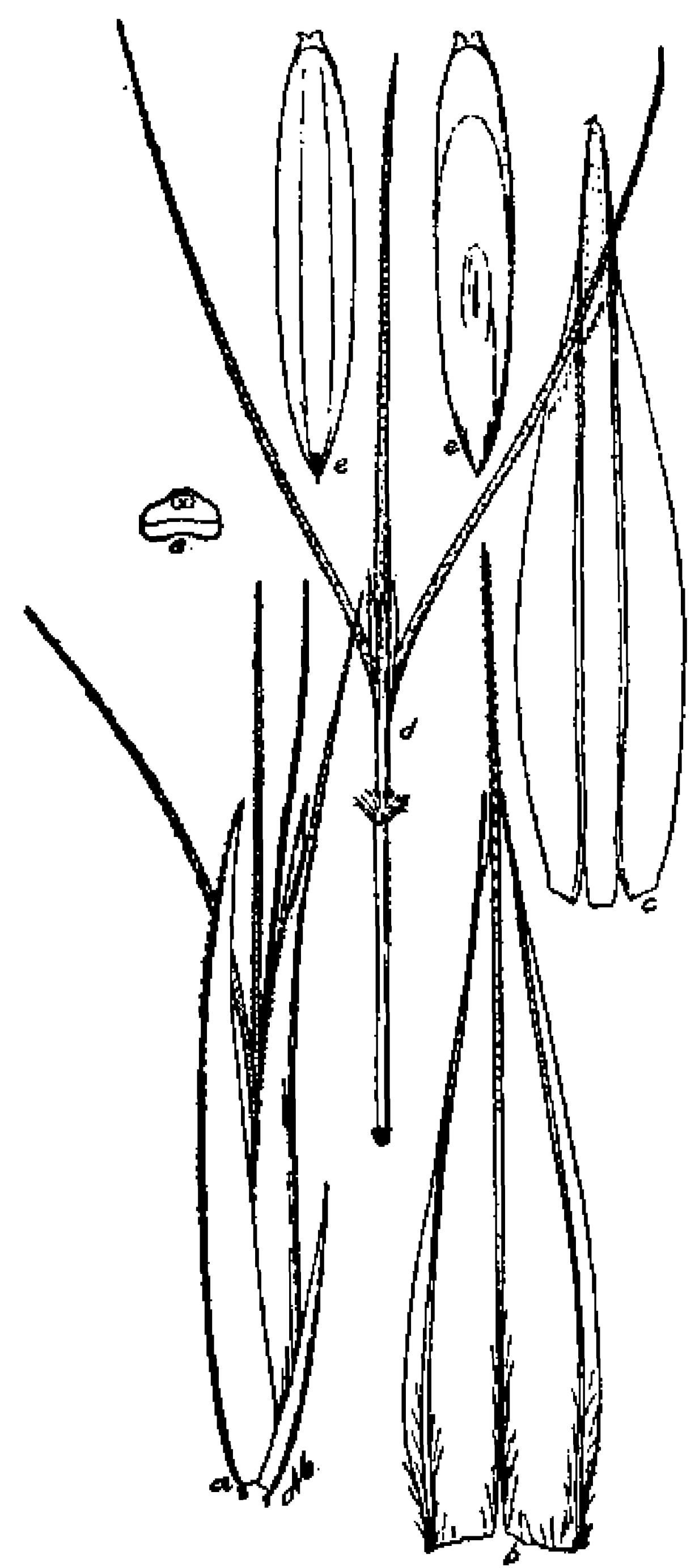

FrG. 44.-Bouteloua eriopoda. a, Spikelet $b, c$, lemma and palet of first floret; $d$, rudiment; $e$, two tiews and cross-section of caryopsis. $a$, Scale $7.5 ; b-e$, scale 10 . From Griffiths 7002. Chondrosium eriopodum. See also L. S. Dept. Agr. Div. Bot. Bull. 12 ${ }^{1}$ : pl. 87.1890 ; U. S. Dept. Agr. Div. Agrost. Bull. 7 : 217. f. 199. 1897.

Bouteloua brevifolia Buckl. Proc. Acad. Plila. 1862: 93. 1862. Asa Graya reviews Buckley's descriptions and refers this to $B$. eriopoda Torr. and shows that it was based upon Wright's no. 748 and Fendler's no. 950 (not 946 as on ticket in the Pliladelphia Acaderny IIerbarium).

\section{DESCRIPTION.}

A cespitose perennial, growing commonly in large bunches, separited by intervals of a few inches to a few feet of bare ground, or occasionally a weedy annual, but seldom in shade of shrubs; culms geniculate, rather weak, woolly, 40 to 60 $\mathrm{cm}$. long, commonly branched, and in warmer localities sparingly perennial, with close, striate, smooth sheaths, small ciliate-tringed ligule, and narrow, convolute, smooth blades; panicle racemose, 10 to $15 \mathrm{~cm}$. long; spikes 3 to 8 , commonly 4 or 5,2 to $3 \mathrm{~cm}$. long; spikelets 12 to 20,7 to 10 mm. long, loosely pectinate, consisting of one lower fertile floret and an upper rudiment; glumes very unequal, the first about $3 \mathrm{~mm}$., the Becond about $7 \mathrm{~mm}$. long, keeled, smooth, or the second minutely scabrous at the apex; Iemma minutely hairy below, 3-awned, the lateral awns very shoit, the central equaling those of the rudiment, himpid, 2 mm. long; palet awnless, acuminate, alout $5 \mathrm{~mm}$. long; rudiment consisting of 3 equal, hispid awns $4 \mathrm{~mm}$. long, united at base by very minute scales and supported upon a slender, smooth stipe $2 \mathrm{~mm}$. long, hairy-tufted at each chd; "aryopsis cylindrical-oblong, 2.5 to $3 \mathrm{~mm}$. long, 0.25 to $0.35 \mathrm{~mm}$. wide, the scutellum covering three-fourths of the ventral surface. (Plate 74, B, facing p. 388. Figure 41.)

The lax, pectinate inflorescence and woolly culms readily distinguigh this species. In publications of the United States Department of Agriculure it has usually been called "woolly-foot" but in portions of the Rio Grande Valley of New Mexico, where 
it is most abundant, "black grama" is the name by which the stockmen know it. In and adjacent to the Mesilla Valley it occupies large stretches of the open, gently sloping country between the rugged upper foothills and the brushy regions of the lower foothills and mesas above the bottom lands. The crop here in exceptionally favorable years is heavy enough to be mown for hay. No other region is known which makes such a heavy crop, although it is an abundant and familiar grass throughout the arid Southwest and extends far into Mexico.

There has never been much confusion regarding its identity, and although very variable the species is easily distinguished when once recognized. Wright 18 and 748; Jones 54a; Pringle 411; Mearns 2267 and 2089; and Wooton 458 are typical.

\section{HERBARIUM SPECIMENS}

Arizona: Griffths 1825, Mescal; 1669, Rincon Mountains; 3395 and 3367, Santa Rita Forest Reserve. Jones 6067, Pipe Spring; 4262, Bowie; Griffths \& Thornber 1, Santa Rita Forest Reserve; .233, Empire Ranch. Leibcrg 5931, Bright Angel Trail, Grand Canyon. Mearns 865, south of Bisbee; Rusby 892, Yavapai County. Purpus 8276, Beaver Creek. Toumey, Chiricahua Mountains.

New Mexico: Plank 18 and 5, Socorro. Griffiths 3337, Deming. Mearns 2333, Dog Mountains. Metcalfe 631, 1451, Kingston; Wright 2018; Jones 54a, Albuquerque. Wooton \& Standley, Tortugas Mountains; 3973, cast of Dona Ana Mountains. Hitchcock 3740, Deming; 3787, Organ Mountains. Wooton 458, Las Cruces.

Texas: Plank 69, El Paso. Tray 8283, Barstow. Carleton 417, Oldham County. Mexico: Pringle 411, Chihuahua. Wilkinson 348, Santa Eulalia Plains, Chihuahua. Mearns 2089, base of San Luis Mountains, Mexican Boundary.

\section{Bouteloua rothrockii Vasey.}

Bouteloua polystachya major? Vasey in Wheeler, Rep. U. S. Surv. 100th Merid. 6: 287. 1878. This is based upon Rothrock's no. 691, Sonoyta Valley, Arizona, September, 1874. The specimen is in the National Herbarium. It is the narrowspiked form, typical of $B$. micrantha Scribn. \& Merr. See also Vasey, Grasses U. S. 33. 1883, and Descr. Cat. Grasses 63. 1885. Both this variety and $B$. rothrockii are listed in the former reference.

Bouteloua rothrockii Vasey, Grasses U. S. 33. 1883, name only; Contr. Nat. Herb. 1 : 268. 1893, containing the first description. The type is Rothrock's no. 347, Cottonwood, Arizona, 1874. See also U. S. Dept. Agr. Div. Agrost. Bull. 7 : 221. f. 203. 1897.

Bouteloua micrantha Scribn. \& Mert. U. S. Dept. Agr. Div. Agrost. Circ. 32: 8. 1901. Bazed upon Griffith 1556, Fort Lowell, Arizona, September, 1900. This is a narrow-spiked form of $B$. rothrockii grown under favorable circumstances in an irrigated, poorly cultivated field. It is typical of $B$. polystachya major + Vasey.

\section{DESCRIPTION.}

A tufted, erect, sparingly branched, smooth, short-lived perennial, 25 to $50 \mathrm{~cm}$. high; sheaths striate, smooth, rather tightly fitting but often open at maturity, the ligule reduced to a ciliate fringe; blades abundant toward the base of culm, 6 to $10 \mathrm{~cm}$. long, 2 to $3 \mathrm{~mm}$. wide, smooth or usually with a few long, scattered, delicate, papillose hairs on the upper surface and edges, the margin minutely serrate; panicle racemose, 10 to $25 \mathrm{~cm}$. long; spikes 4 to 10 or $12,2.5$ to $3 \mathrm{~cm}$. long and $5 \mathrm{~mm}$. wide; spikelets pectinate, 40 or 50 , about $6 \mathrm{~mm}$. long, including awns; glumes minutely scabrous, keeled, the first about one-half the length of the second and with an awn about $1 \mathrm{~mm}$. 
long; lemma about $5 \mathrm{~mm}$. long, loosely hairy, with long, white hairs, the four teeth fringed or frayed into minute, hair-like teeth, with 3 scabrous awns, 1 to $1.5 \mathrm{~mm}$. long, palet 4-notched, two-nerved with two scabrous awns, hairy on the edges and laciniate at apex like the lemma, $4 \mathrm{~mm}$. long; rudiment consisting of two rudimentary floreta, the lower composed of rudimentary scale-like glumes and three long, scabrous awns (about $3 \mathrm{~mm}$. long), subtended by a tuft of long, straight, white hairs, all borne upon a naked stipe $1 \mathrm{~mm}$. Iong; second rudiment consisting of scalc-like glumes upon a naked, short stipe; caryopsis ovate to obovate, about $1.25 \mathrm{~mm}$. long, the scutellum covering nearly the entire ventral surface. (Plate 75, A, B. Figures $45,46$.

There are large areas in southern Arizona and neighboring regions where this is the most important grass of the stock ranges. It inhabits the upper mesas and the

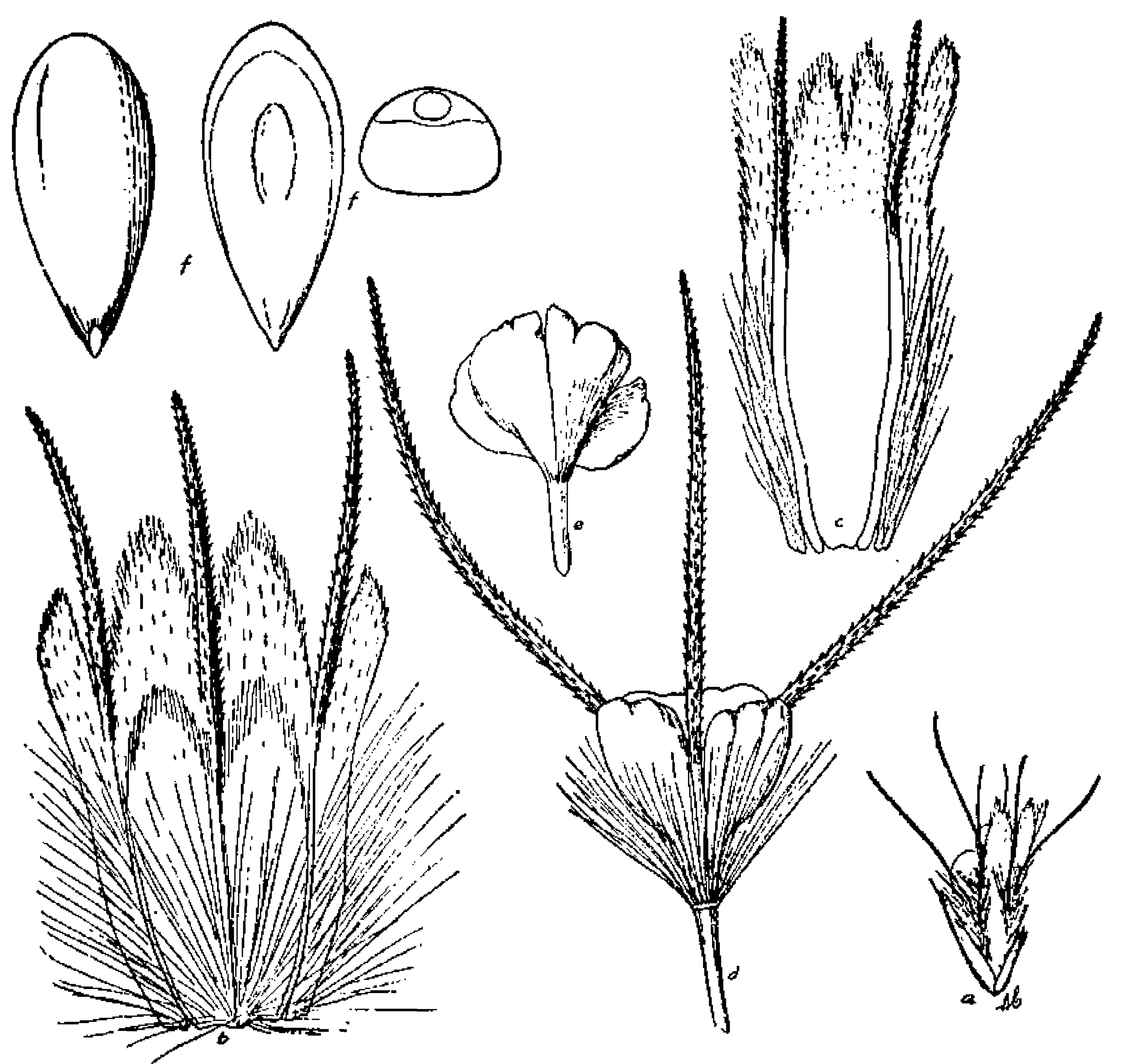

FIo. 45.-Boutelowa rothrockii. $a$, Spikelet; $b, c$, lemma and palet of first floret; $d, e$, rudimentary second and third florets; $f$, two viows and cross-section of caryopsis. $a$, soale $7.5 ; b-f$, scale 20 . a-e, From $t y p e$

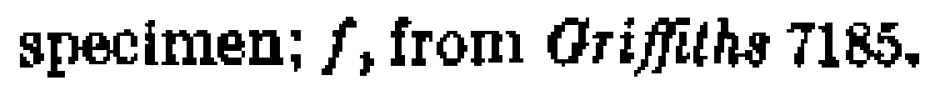

gentle, brushless slopes of the foothills during the summer rainy season, July to September, often to the exclusion of all other specins. It is a very characteristic species, and although of ten appearing to in tergrade with $B$. barbala it is very distinct and easily distinguished in the field. There are many specimens, however, which are very difficult to separate from $B$. barbata on the herbarium sheet. When the

Explanation of PLate 75.-A. An isolated tuft of Bouteloua rothrockit on desert enst of Tucson, Arizona. B. A large native crop of Boulelotia rolhrockit in southern Arizona. This area had not been pastured for five years. 


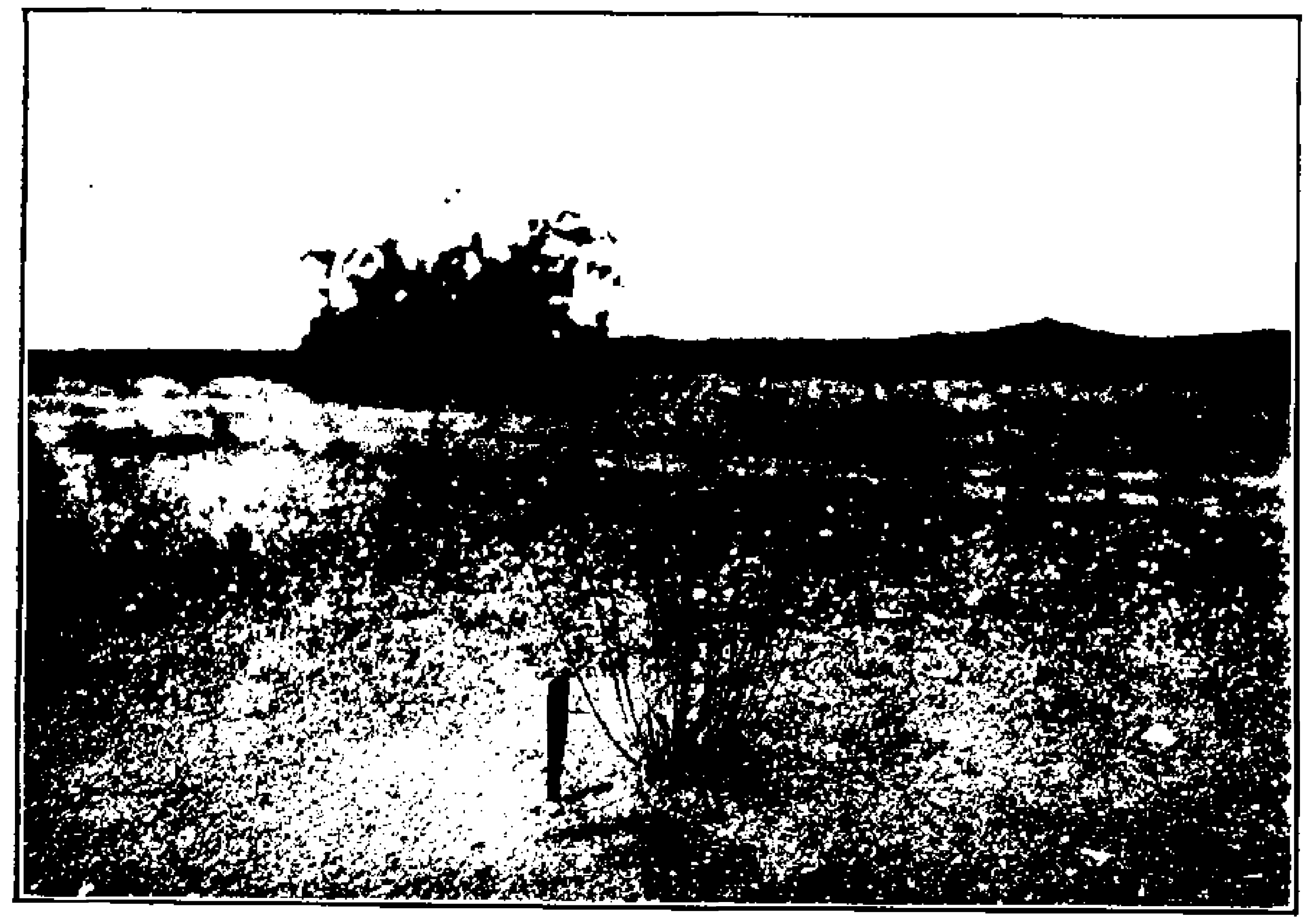

A. Isolated Plant of Bouteloua rothrockil Vasey.

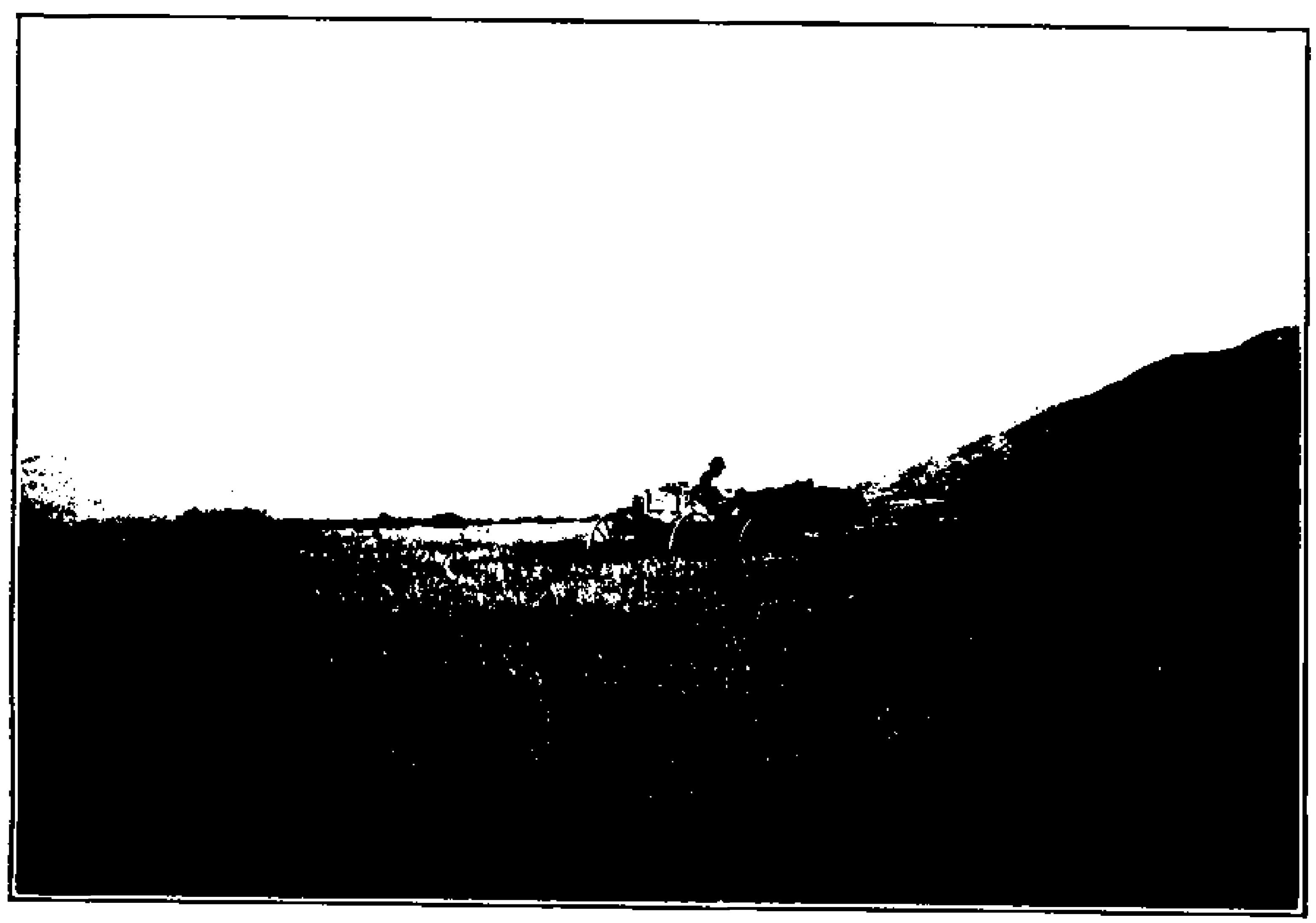

B. Dense Growth of Boliteloua rothrock!! 
epecies is nearing maturity, the landscape is tinted reddish brown by the abundant spikes. In some sections it grows so abundantly that ranchers consider it profitable to cut it for hay. So far as my own observation goes it never yields over one-half ton to the acre of clean, current year's growth (P1. 75, B). In southern Arizona, upon a rainfall of 12 to 18 inches, it grows about 8 inches in the growing season, July to September.

Bouteloua rothrockii is not a grass that withstands close pasturage well. Being a short-lived perennial and a comparatively poorly rooted species, it is easily pulled up and trampled out. The best growths of it today are found in those regions which are at a considerable distance from water available for stock.

It grows in bunches of a few culms to scores of culms, but so far as my observation goes never makes any semblance of a turf. When it happens to grow on partly cultivated ground or in other favorable situations, the bunches may grow very large and the outer culms of the stool become geniculate and even rooted at the joints. Some

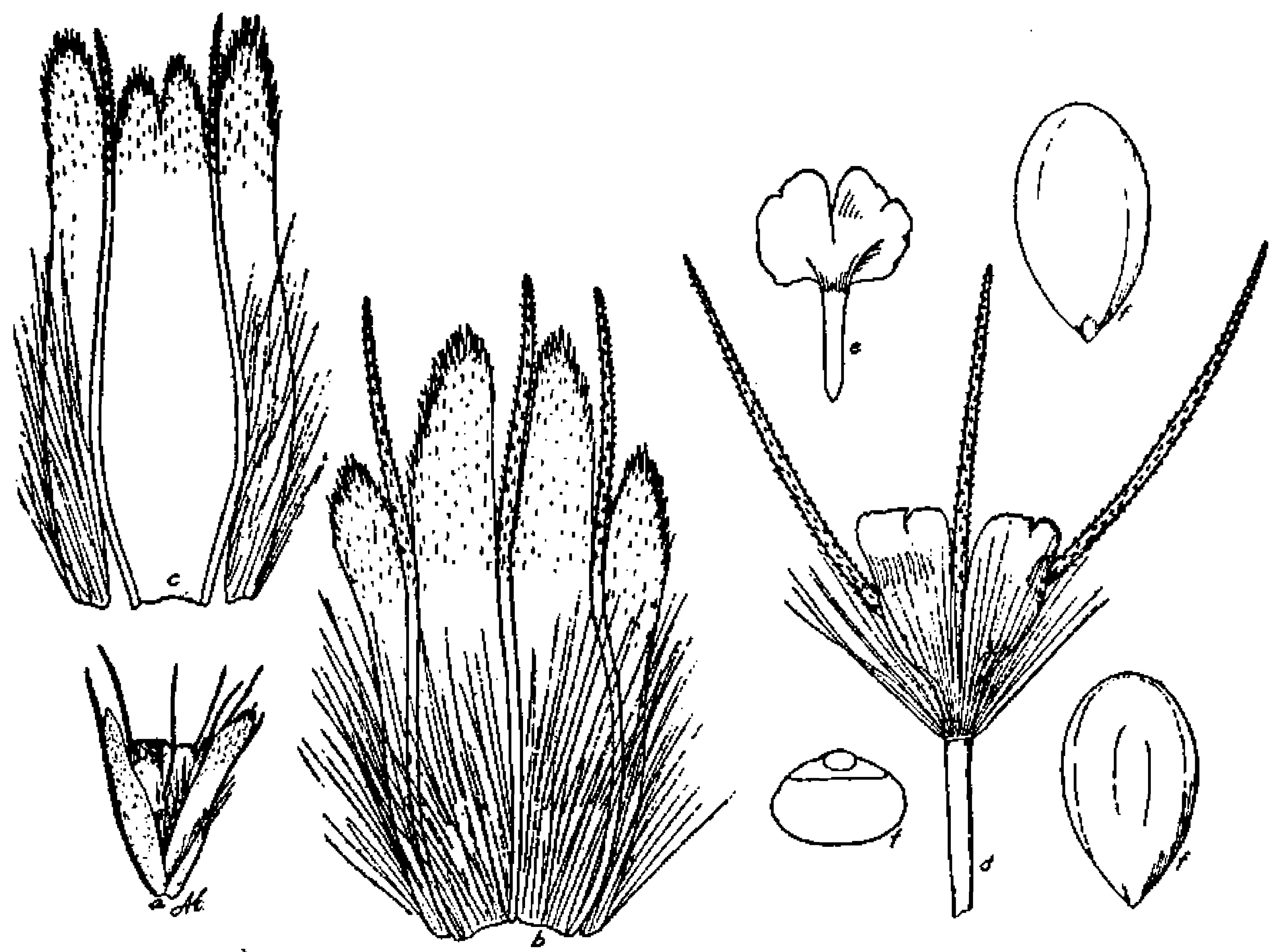

Fig. 48.-Boutelouta rothrockii. $a$, Bpikelet; $b, c$, lemma and palet of first floret; $d, e$, rudimentary second and third florets; $f$, two views and cross-section of caryopsis. $a$, Scale $7.5 ; b-f$, scale 20 . From type specimen of $B$. micrantha.

of my specimens from cultivated ground in the upper Santa Cruz Valley of Sonora show this form of the plant beantifully.

My conception of the apecies is well illustrated by the specimens cited below. Rothrock 691 and Griffith 1556 have narrow epikes and smaller floral parts throughout than the common typical form ( $\mathrm{Pl} .75, \mathrm{~A}$ ).

Palmer's no. 244 and Pringle 221 very well represent the common form. Brandegee, Culiacan, Mexico, October, 1904, and Palmer 204, 1534, and 1761, are geniculate forms. Purpus 94 and Pringle, Arizona, in 1884 without number, represent forms which have about the same relation to the typical species as $B$. arenosa has to $B$. barbata. In these the awns are exceptionally long and the spike very wide. 


\section{HERBARIUM SPECIMENS.}

Arizona: Ifitchcock 3685, Patagonia; 3480, Tucson; 3733, Benson. Griffths 1556, Fort Lowell; 3361, near Tucson; 3402, Santa Rita Forest Reserve; 1785, Rincon Mountains. Mearns 1026, 1064, and 8561, south of Bisbee. Grifliths \& Thornber 199 and 9, Santa Rita Mountains. Purpus 94, Antelope. Pringle in 1884 near Mexican Boundary. Rothrock 691, Sonoyta Valley; 347, Cottonwood. Nealley, Tanque Verde. Wilcox, Fort Huachuca. Jones 4014, Flagstaff. Lemmon 429, 430. Toumey 807, and 512, Tucson.

UTAH: Jones, Moab.

Mexico: Hitchcock 3583 and 3536, Hermosillo; 3523, Llano. Palmer 235, 166, and 204, Guaymas; 791, Agiabampo; 1543, Culiacan; 1761, Ymala. Brandegee, Culiacan.

\section{Bouteloua karwinskii (Fourn.).}

Chondrosium karuinskii Fourn. Mex. Pl. 2: 137, 1881. The type is Karwinski 1479 from "Cañon de las Minas et Victoria," Mexico. This number was not found in the

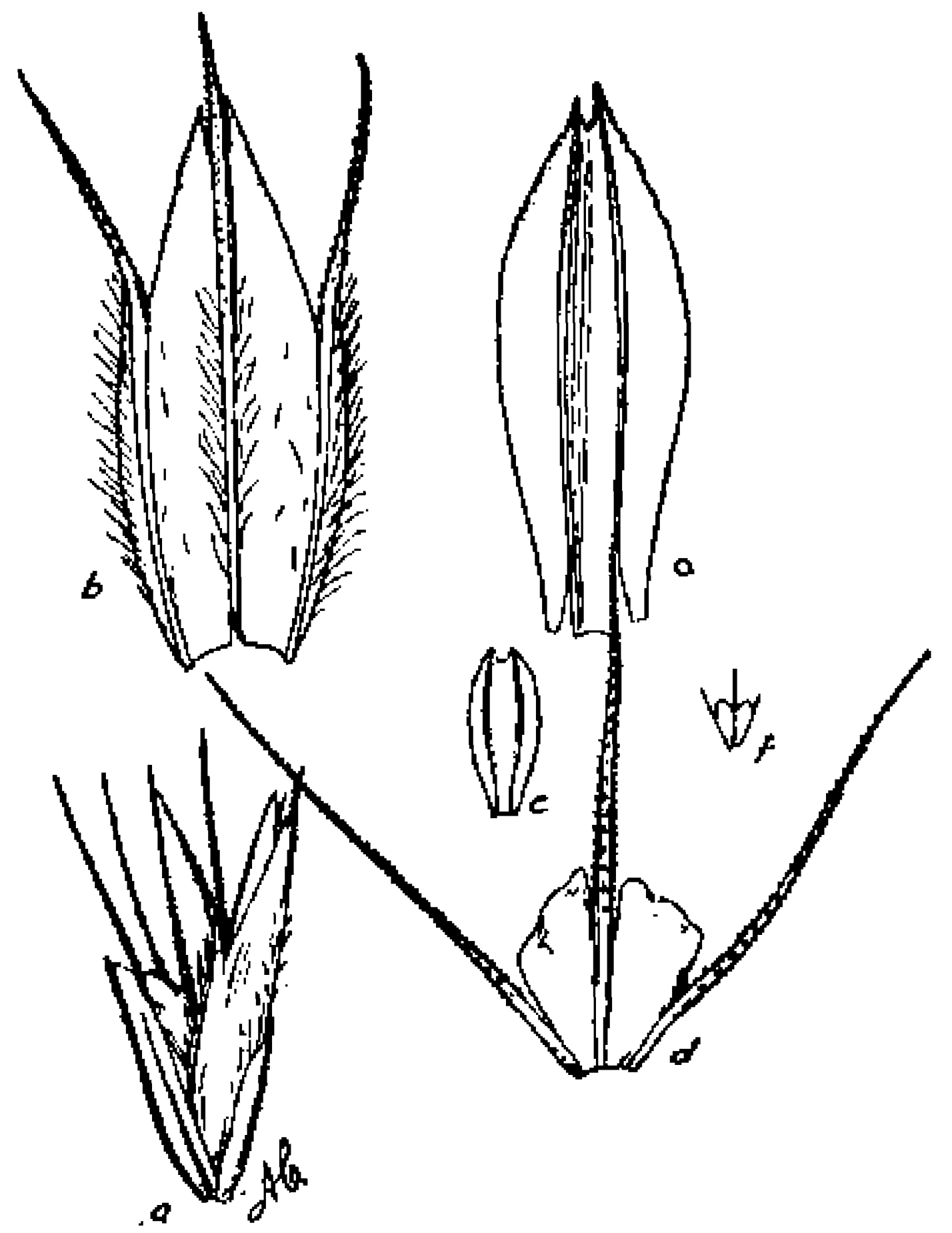

FIG. 4i.-Boutcloua karwinskii. $a$, Spikelet; $b, c$, lemma and palet of first floret; $d$, $c$, rudimentary lemma and palet of second floret; $f$, rudiment of third floret. $a$, Scale $6.60+; b-f$, scale 10. From Karwinski 1479, in St. P'etersburg JTerb.

$\mathrm{mm}$. long and 5 or 6 in number; spikelets pectinate on a flattened, short, hairy, zigzag rachis, consiating of a lower perfect and an upper three-awned rudiment, with scales and awns arising from a naked stipe about $1 \mathrm{~mm}$. Iong; glumes smooth, the second about $2 \mathrm{~mm}$. long, the first a little shorter, acuminate, scarcely awned; lemma 2 to $2.5 \mathrm{~mm}$. long, pubescent, with 3 equal awns; palet albout the length of its lemma, with 2 very short awns, plicate; caryopsis not scen. (Plate 76. Fraure 47.)

a Biol. Centr. Amer. Bot. 3: 564, 1885.

Explanation of Plate 76.-Natural habitat of Bouteloua karwinskit, B. trinii, and B. alolonifera among vegetation consisting largely of Cercus, Opuntia, Jatropha, etc., east of San Luis I'otosl, Mexico. 


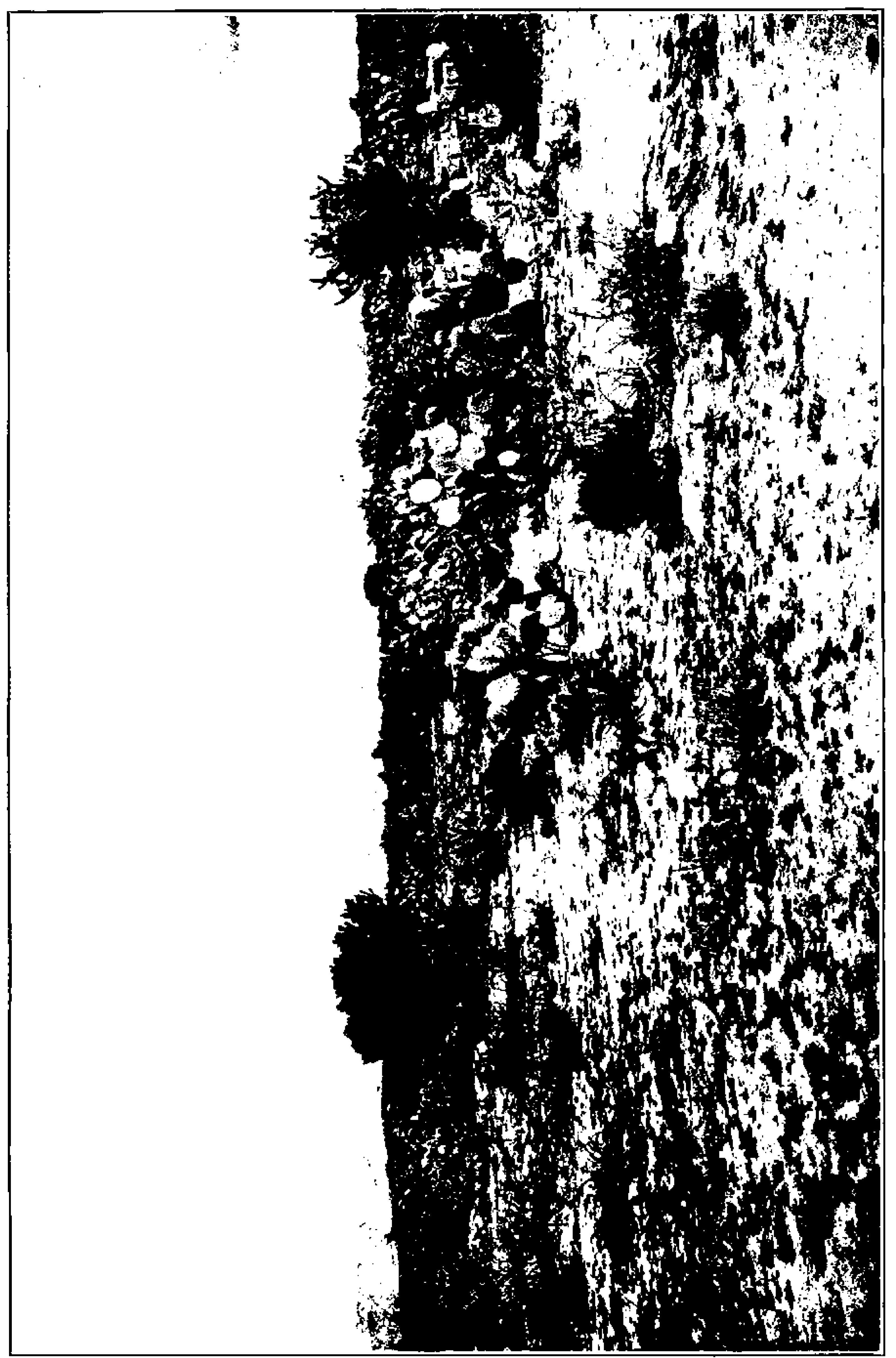


The species appear to be native from San Luis Potosi northward. It is distin. guished by its strong, harsh, woody base and by its spikes, which, although they resemble those of $B$. barbata, are slightly wider and shorter.

The first material seen was collected by myself near Alonzo, Mexico, March 14, 1905 (no. 7650). All specimens were of the previous year's growth, and consequently not satisfactory. Recently Lloyd has contributed very materially to a knowledge of the species by two collections (nos. 170 and 183) from Hacienda de Cedros, in northern Zacatecas. These and a panicle of a duplicate of the type are all the material which has been seen.

\section{Bouteloua alamosana Vasey.}

Bouteloua alamosana Vasey, Contr. Nat. Iferb. 1 : 115. 1891. Edward Palmer's no. 698, Alamos, Sonora, Mexico, September 10 to 30,1890 , is the type.

\section{DESCRIPTION.}

A tufted, aparingly hairy annutl with geniculate, ascending or prostrate, sparingly branched culms, 4 to $20 \mathrm{~cm}$. high; sheaths striate, rather loose, with scattered, papil-

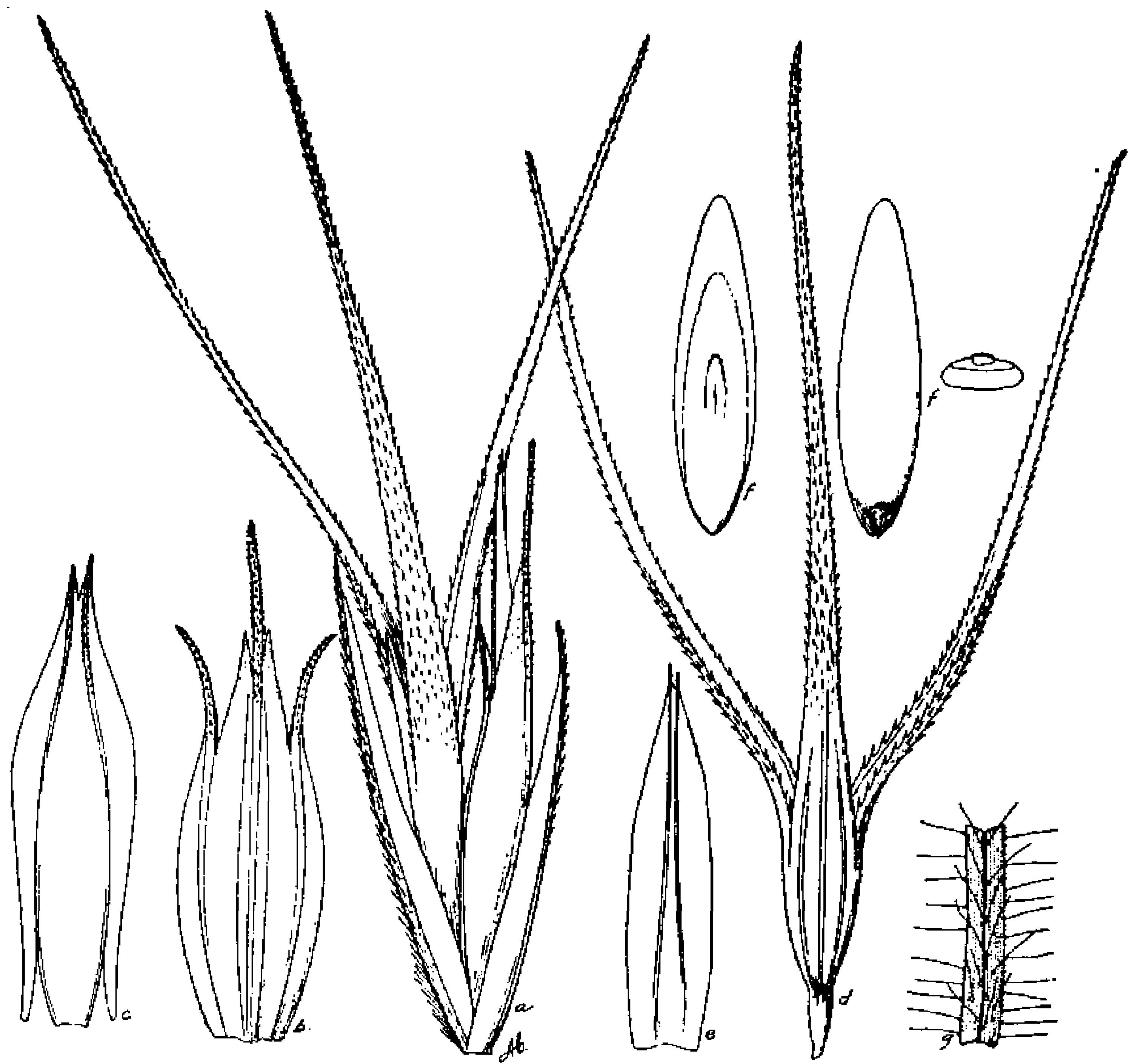

FTg. 45.-Bouteloua alamosana. $a$, spikelet; $b_{2} c$, lemma and palet of first floret; $d, e$, rudimentary lemmn and palet of second floret; $f$, two views and cross-section of caryopsis; $\theta$, portion of lesf blade. a-f, Sale $7.5 ; g$, scale 2.5 .

lose hairs, especially near the edges, the ligule consisting of a white, ciliate fringe; blades minutely hispid, especially above, and bearing long, papillose hairs at regular intervals on the maryins and scattered and less numerous hairs on the surfaces; panicle racemose, 2.5 to $4 \mathrm{~cm}$. long; spikes 3 to 5,10 to $15 \mathrm{~mm}$. long, very similar to those of $B$, texana, containing 3 to 5 spikelets, these often consisting of one floret and a rudi- 
ment, this in the proximal spikelet very much reduced; first glume $5 \mathrm{~mm}$, the eecond $6 \mathrm{~mm}$. long, scabrous-keeled; lemma 6 to $7 \mathrm{~mm}$. long, 3-awned, the central awn about $1 \mathrm{~mm}$. longer than the lateral, smooth, the awns scabrous; palet 2-awned, smooth, the awne scabrous; rudiment consisting of a staminate floret, the lemma bearing 3 long, scabrous awns, about $11 \mathrm{~mm}$. long, lateral awns about $2 \mathrm{~mm}$. shorter; palet similar to but amaller than that of the perfect floret; caryopsis cylindrical-ovate, $4 \mathrm{~mm}$. long, $0.75 \mathrm{~mm}$. wide, the large scutellum three-fourths the length of the entire caryopsis or more. (FIGURE 48.)

The type specimens furnish most of the knowledge which we have of this species, which grows upon rocky ridges on the Pacific coast of the State of Sonora, Mexico. It is very distinct from any of the other species. It resembles $B$. aristidoides in general habit but is a coarser, more leafy plant, and the spikes are more like those of $B$. texana.

Judging from the material in the National Herbarium this ahould be found commonly on the Pacific coast of Mexico, south from the State of Sonora. Besides the type speciment there is one collected by Earl Flint in Granada, Nicaragua, in February, 1868 , which is at least very close to this epecies. Confirmatory material from Nicaragua is necessary.

\section{Bouteloua aristidoides (HI. B. K.) Grieeb.}

Dinebra aristidoides H. B. K. Nov. Gen. \& Sp. $1: 171$. 1816. The plate of this $a$ in a later volume identifies the species without doubt.

Atheropogon aristidoides Roem. \& Schult. Syst. Veg. 2: 415. 1817. Based upon Dinebra aristidoides H. B. K. See also Spreng. Syst. Veg. 1 : 293. 1825; Fourn. Mex. Pl. 2 : 139. 1881.

Eutriana aristidoides Trin. Gram. Unifl, 242. 1824. Based upon Atheropogon aristidoides H. B. K. See also Steud. Syn. Pl. Glum. 1 : 216.1854.

Dineba hirsuta Presl, Rel. Haenk, $1: 292$. 1830. The type epecimen is in the herbarium of the National Museum at Prague.

Eutriana hirsuta Kunth, Enum. P1. 1:280. 1833. Based upon Dineba hirsuta Presl.

Aristida unilateralis Willd.; Steud. Nom. Bot. ed. 2. 1:132. 1840. A herbarium name of Willdenow published as a synonym of Eutriana aristidoides.

Bouteloua aristidoides Griseb. F1. Brit. W. Ind. 537. 1864. Based on Dinebra aristidoides H. B. K. See also U. S. Dept. Agr. Div. Bot. Bull. $12^{\prime}: p l .35 .1890$; U. S. Dept. Agr. Div. Agrost. Bull, 7 : 214. f. 196. 1897.

Bouteloua gracilis Hook.?; Vasey in Wheeler, Rep. U. S. Surv. 100th Merid. 6 : 287. 1878, not Lag. 1840. The type is Rothrock's no. 701.

Bouteloua ciliata Griseb. Abh. Ges. Wiss. Göttingen 19:302. 1879 (Symb. Fl. Argent.). The type specimen, Lorenz \& Ifieronymus 352, from Juramento, Argentina, is in the Grisebach Herbarium.

Triathera aristidoides Nash in Small, Fl. Southeast. U. S. 137. 1903.

\section{DESCRIPTION}

A tufted, erect or decumbent, smooth annual, with uright or geniculate culms, altogether too variable in size to permit of the preparation of lineal descriptions of any value; theaths loose, especially on branching culms, atriate, the lower one-third to one-half the length of the internode, the upper sometimes nearly as long, this depending upon the character of the season; ligule reduced to a membranaceous line or slightly fimbriate, with a few scattered hairs; blades small, few, 2 to $7 \mathrm{~cm}$. long, with a few scattcred hairs on the upper surface; panicle variable, 2 to 7 or $8 \mathrm{~cm}$. long, but often in vigorous plants $15 \mathrm{~cm}$. long, bearing normally 10 to 14 spikes, but under 


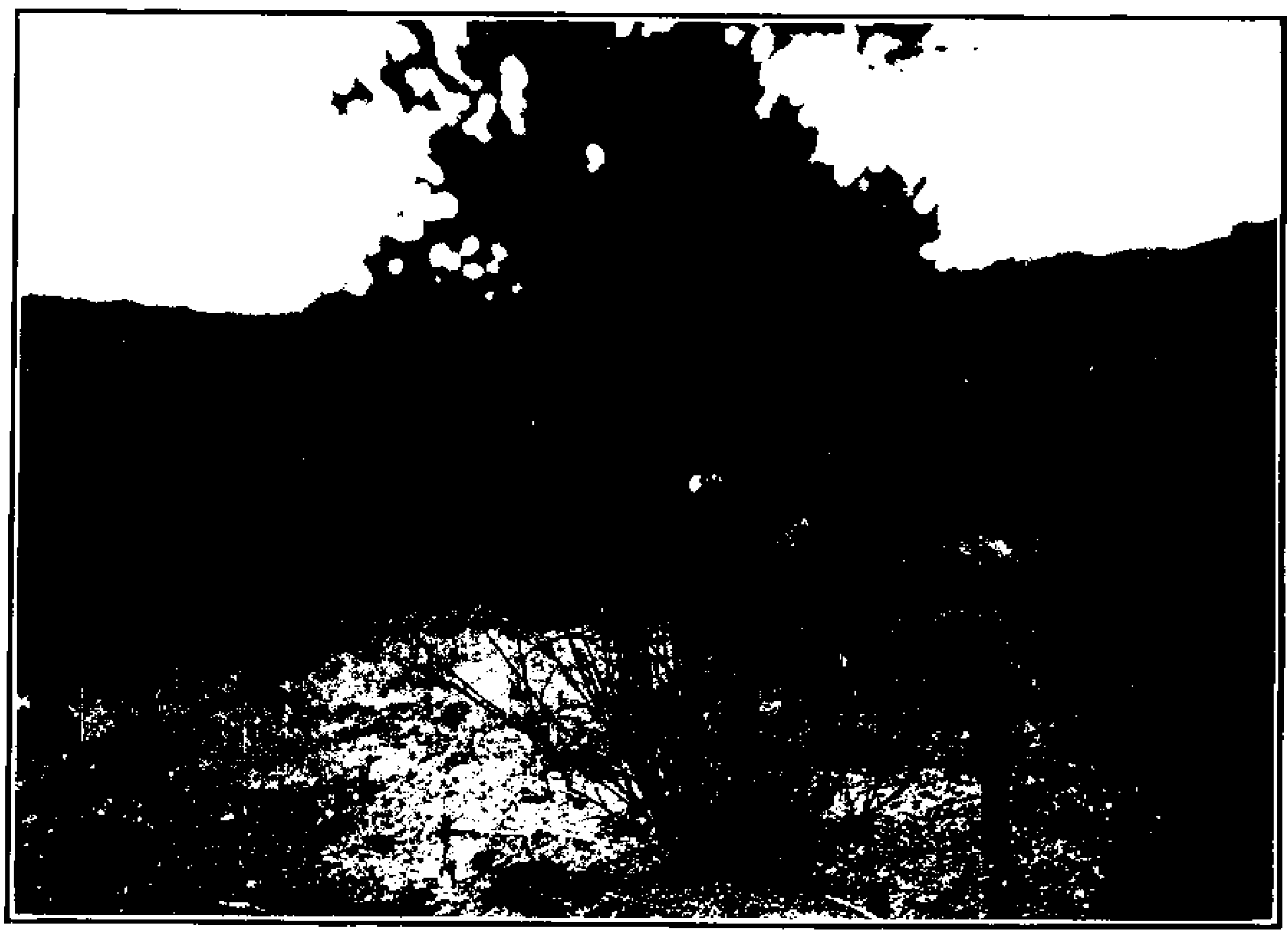

A. Large Plant of Bouteloua aristidoides (H. B. K.) Griseb.

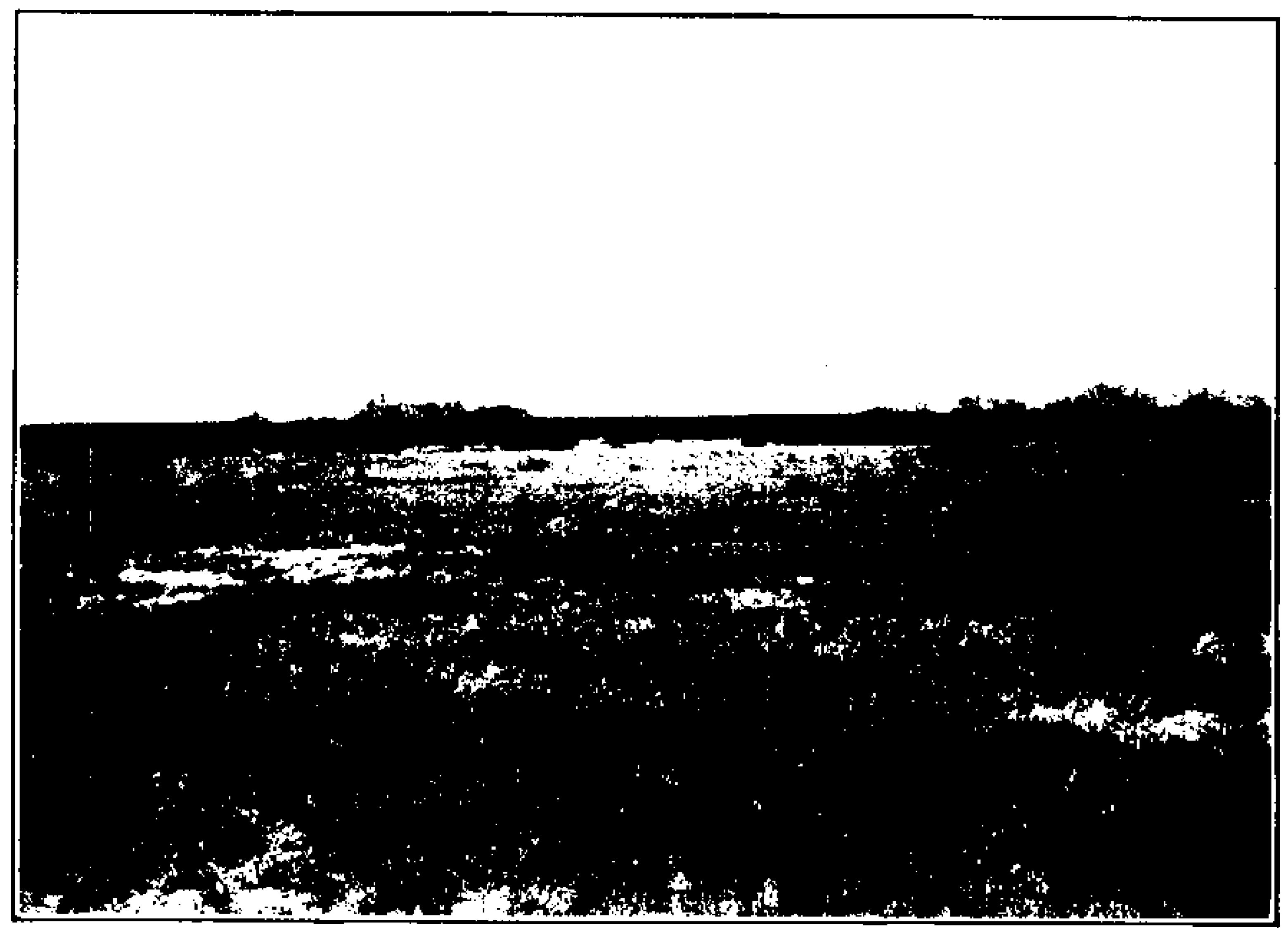

B. Same species on Desert mesas. 
unfavorable conditions sometimes reduced, in stunted plants, to 2 to 4 ; spikes pedunculate, the peduncles about $1 \mathrm{~mm}$. long, these, together with the rachis densely whitehairy over the entire surface or only on the angles, the pubescence diminishing in quantity distally to only scattering hairs upon the distal prolongation of the rachis; spikelete 2 to 4 , the lowermost more or less aborted, loosely arranged, about $2 \mathrm{~mm}$. apart, consisting of a perfect floret and a rudiment, this red uced or usually absent in the lower spikelet; first glume 1.5 to $2 \mathrm{~mm}$., the second 5 to $6 \mathrm{~mm}$. long, minutely scabrous-keeled, both narrow, acuminate; lemma with three, very short, nearly equal, minutely scabrous awns, pubescent, mostly on the 3 nerves, 6 to $8 \mathrm{~mm}$. long; palet smooth, with two very short, very minutely scabrous awns, about 5 to $6.5 \mathrm{~mm}$. long; rudiment consisting of 3 long, scabrous awns upon a hairy stipe, $1 \mathrm{~mm}$. long, bearing a tuft of longer hairs at its apex, the central awn slightly glumaceous at base and about $2 \mathrm{~mm}$. shorter than the lateral, the whole rudiment being about $7 \mathrm{~mm}$. long; caryopsis cylindrical-oblong, 3 $\mathrm{mm}$. long, $0.4 \mathrm{~mm}$. wide, grooved on the dorsal surface, the scutellum about three-fourths tho length of the ventral surface. (Plate 77, A, 13. Figure 49.)

The apecies inhabits the drier desert mesas and foothills from western Texas to the Pacific coast and is as variable as the seasons and conditione in this most variable region. Often it will mature its seed upon a single culm 1 or $2 \mathrm{~cm}$. high, or it may produce plants with 50 culms $70 \mathrm{~cm}$. in height. Often the spikes are not over 3 or $4 \mathrm{~mm}$. in length and produce but a single seed, while in Palmer 51 some spikes are fully $2.5 \mathrm{~cm}$. in length. The habits of growth of this species particularly fit it for a desert habitat. It is an annual, producing an abundance of seeds which have their special methods of dis-

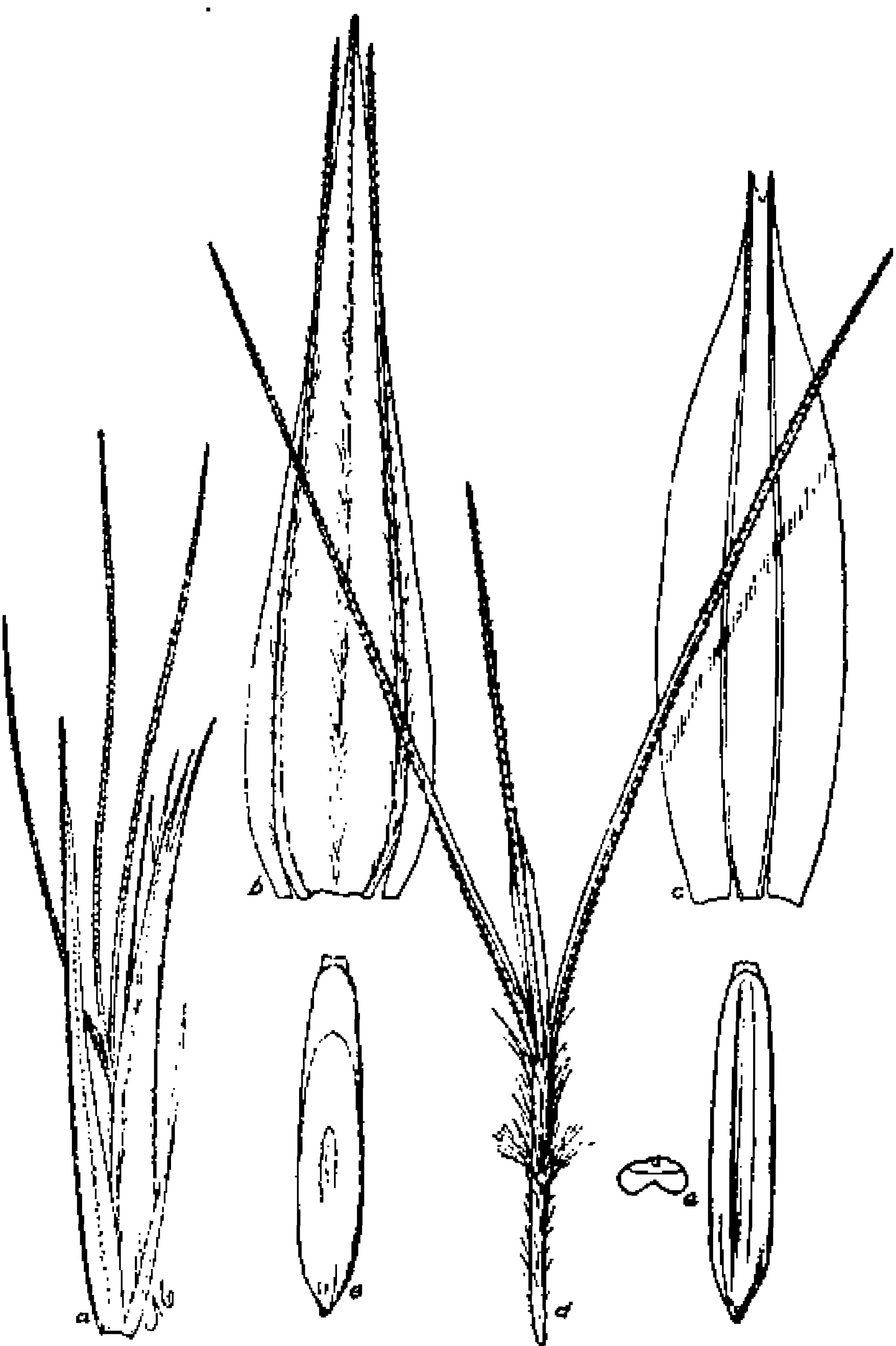

Fig. 49.-Bouteloua aristidotdes. a, Spikelet; $b, c$, lemma and palet of first floret; $d$, rudiment; $e$, two views and cross section of caryopsis. a, Beale 7.5; b-e, scale 10. From Griffiths 7308.

semination by burrowing into the ground and thus enable it to persist where rese aggressive plants fail. When mature the spike, together with the short, sharp-pointed perluncle, drops off entire. This callus-like peduncle is thickly beset with short, stiff, retrosely arranged hairs, which, together with the awns of the spikelets and the recurved awn-like prolongation of the rachis, assist in the burial of the seed or its adhesion to anything with which it may come in contact.

This is doubtless one of the least valuable of the abundant species of this genus. Usually no grazing is done upon it during the time that it is ripening, and, where very

Explanation of Plate 77.-A. A very large plant of Boutcloua aristidotdes from a favorablo depression In desert mosas east of Tucson, A rizonf. B. A nearly pure stand of the same upon the desert mesas north of the Santa Rita Mountains of Arizona, in a very favorable season. 
plentiful, sheep are removed from it on account of the injury inflicted by the sharppointed spikes which work into their feet and disable them. When young, especially before blooming, it is readily grazed by stock, but even then tho plants too easily pull up by the roots, the feed therefore being mixed with aand toan annoying extent. In late autumn, after the spikes have fallen off, the grass apparently affords but little nutriment and stock avoid it as much as possible. Associated with it in this country is usually found Aristida humboldtiana, which has similar characteristics and which adds to the injurious effects.

\section{HERBARIUM SPECIMENS.}

Arizona: Mearns 1122, San Pedro River near Mexican Boundary; 924, south of Bisbee. Rothrock 701, Riley's Well (near Tucson). Smart 429, Camp McDowell. Rusby 891, Beaver (reek. Toumey 802 and in Seymour's Grasses 84, Tuceon. Griffths 1523, 3343, Tueson; 1922, Cochise; 1818, Mescal; 1928, Pearce; 3379 and 3418, Santa Rita Forest Reserve. Jones 6065, Canaan Ranch. Wilcox, Fort Huachuca. Blumer 1705, Paradise. IItchcoek 3490, 3507, 3510, Tucson; 3665, Patagonia.

Calmoknia: Orcutt, San Diego.

New Mexico: Mulford 1000, Florida Mountains. Metcalfe 702, Silver City. Cockerell 18, Jarilla Junction. Plank 43, Socorro. Wooton 1053, Las Cruces; 411, Donna Ana County. Mearns 2340, Dog Mountains; 924, south of Bisbee. Iritchcock 3750, Jeming.

Texas: Cockerell 14, Fort Bliss. Plank 8, Llano; 63, El Paso. Nealley, Laredo.

Mexico: Palmer 1353, 1354, Soledad, Chihuahua; 162, Guaymas; 1650, Lodiego; 1547, Culiacan; 7, Yaqui River; 177 and 714a, Durango; 859, Carmen Island; 697, Alamos. Pittier 474, Tlahualilo, Durango. Brandegee, Culiacan; 4, San José del (abo, Lower California. Schallner, San Luis Potosí. Pringle 477, Chihuahua; 4592, Tequila. Parry \& Palmer 941, San Luis Potosi. Ilitcheock 3638, Nogales; 3594 and 3533, Hormosillo; 3549, Guaymas; 3527 and 3519, Llano. Rose 2490, San Juan Capistrano. Nelson 6329, Casas Grandes, Chilhuahua.

South America: Stucket 10624, 12791, 13764, and 20114, Argentina; Kneucker Gram. Exsic. 448; Kurtz Herb. Argent. 12670.

\section{Bouteloua pringlei Scribn.}

Bouleloua pringlei Scrihn. C. S. Dept. Agr. Div. Agrost. Cire, 30:4. 1901. Type, Pringle 8374, collected in the mountains above Iguala, Guerrero, Mexico, October 24, 1900 , in the National Herbarium.

\section{DESCRIPTION.}

$\Lambda$ erect, cespitose perennial, a meter high, resembling $B$. curtipendula in general appearance and habit; culms erect, fimple; nodes and internodes smooth, but sheaths densely papillose-hairy upward, nearly smooth below, rather loose, with a small, densely hairy ligular region; blades long, flat, 5 to $7 \mathrm{~mm}$. wide, more sparingly papillose-hairy; inflorescence racemose, the lower apikes showing a slight tendency to become compound, about $30 \mathrm{~cm}$. long, the spikes arranged bilatcrally but so curved or twisted, especially above, as to appear unilateral; spikes variable in size, small above and passing graduilly into larger ones below, and finally by indistinet gradations into spike-bearing branches in the lower portion of the incipient panicle; spikelets 4 to $5 \mathrm{~mm}$. long, not pectinate, consisting of a single floret and a rudiment represented by a very short prolongation of the rachilla; first glume nearly $3 \mathrm{~mm}$. long, with hispid kecl, the second densely hairy, nearly $4 \mathrm{~mm}$. long, lanceolate, acuminate; lemma ovate, long ciliate hairy on the edges and terminating in three short, equal, hispid awns, about $4 \mathrm{~mm}$. long; palet oblong, terminating in two short, hixpid awns; rudiment very short, often difficult to distinguish; caryopsis oblong, $2 \mathrm{~mm}$. long, 0.3 
to $0.5 \mathrm{~mm}$. wide, rounded on the back, the scutellum rounded at the apex and covering two-thirds to three-fourths of the ventral surface. (FIGURE 50.)

The only specimens of this species which have been seen are those of the type collection. The species is very closely related to $B$. curtipendula, but is easily distinguished by the felty-pubescent sheaths and the character of the inflorescence.

\section{Bouteloua chondrosioides (H. B. K.) Griseb.}

Dinebra chondrosioides H. B. K. Nov, Gen. \& Sp, $1: 173, p l .58 .1816$. The figures and description and a specimen in the Willdenow Herbarium, collected by Humboldt, show conclusively that this is a young plant of what we have long known in this country as $B$. havardii. There is another specimen in the Trinius Herbarium from Humboldt, determined by Kunth in 1836. The figures cited above are faulty in that they do not show the glumes as hairy as they are.

Bouteloua ovata Lag. Gen. \& Sp. Nov. 5. 1816. Lagasca's description, "culmo subpentastachyo: spicis ovatis: glumis extus pubescentibus," applies very well to a young specimen of $B$. havardii such as the type of Dinebra chondrosioides. This, together with the fact that some of the earlier botanists have suggested that the two names apply to the same species, leads the to this disposition.

Atheropogon chondrosioides Roem. \& Schult. Syst. Veg. 2 : 416. 1817. Based upon Dinebra chondrosioides H. B. K. See also Spreng. Syst. Veg. 1 : 293.1825.

Actinochloa ovata Roem. \& Schult. Syst. Veg. 2: 420. 1817. Based on Bouteloua ovata Lag.

Eutriana cristata Trin. Gram. Unifl. 241. 1824. Based upon Atheropogon chondrosioides Roem. \& Schult.

Chondrosium humboldtianum Kunth, Rév. Gram. 1: 93. 1829. Based upon Dinebra chondrosioides H. B. K. See also Fourn. Mex. Pl. 2 : 136. 1881, where this species is also correctly interpreted. Fournier cites Virlet 1412. This number in the herbarium of the Museum of Paris is exactly comparable with my no.

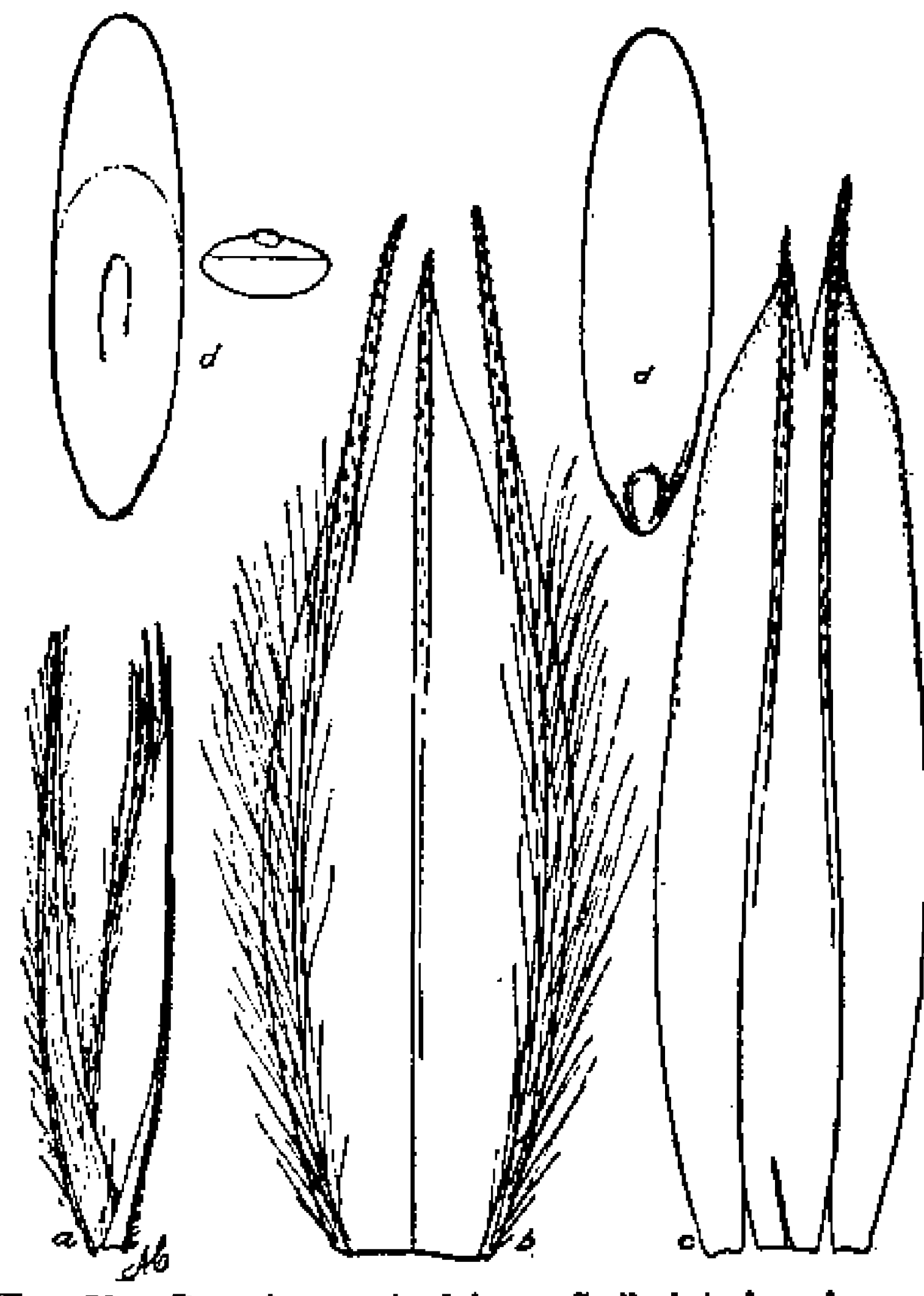

Fig. 50.-Boutelouc pringlet. a, Spikelet; $b, c$, lemma and palet with rudiment 8 ttached; $d$, two views and cross section of caryopsis. $a$, Scale $7.5 ; b-d$, scale 15. From type specimen. 6732 , which is a young specimen of Bouteloua havardii. Schaffner 133, cited by Fournier, in Grisebach's herbarium, is likewise an immature plant of $B$. havardii.

Boutcloua chondrosioides Griseb. in Fourn. Mex. Pl. 2: 136. 1881. This name, presumably based on Dinebra chondrosioides, is mentioned as a synonym under Chondrosium humboldtianum. Watson ${ }^{a}$ gives this combination with Bentham as the author.

Bouteloua havardii Vasey in Wats. Proc. Amer. Acad. 18: 179. 1883. Republished in Bull. Torrey Club 11:6. 1884. The specimen cited in the latter place is Havard in 1881, from Limpio Mountains of western Texas. The type epecimen in the National Herbarium is numbered 53. See also U. S. Dept. Agr. Div. Bot. Bull. 12 ${ }^{1}$ : pl. s8. 1890; U. S. Dept. Agr. Div. Agrost. Bull. $7: 216 . f .198 .1897$. 


\section{DESCRIPTION.}

$\Lambda$ stout, erect, mostly cespitose perennial, with leafy base and comparatively naked culms, striate, loose sheaths, small, sparingly ciliate, pubescent liwales, and slender, flat, rather rigid blades, slightly pubescent beneath; panicle ramenose, about $4 \mathrm{~cm}$. long; epikes 4 to 6 , densely woolly, 1 to $1.5 \mathrm{~cm}$. Iong, fhort-pediccllate from the sharp angles of a zigzag rachis; spikelots consisting of one lower perfect floret and a rudiment, more or less pectinate before anthesis, but this arrangement lost with the development of the long, rigid awns; first glume about $3 \mathrm{~mm}$. long, the second about $4 \mathrm{~mm}$. long, both

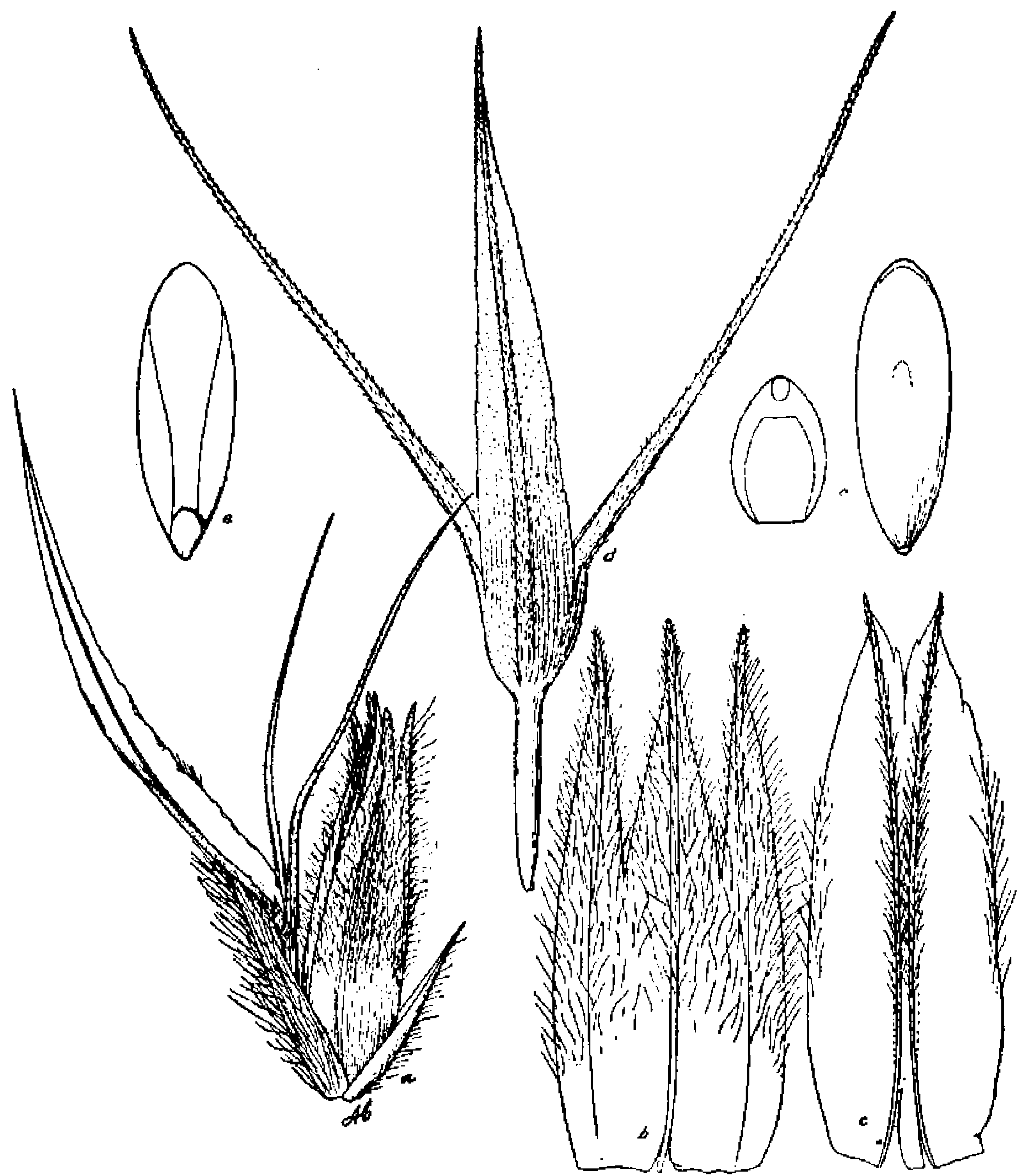

Fia. 51.-Bouteloua chondrosioidcs. a, spikelet; $b, c$, lemma and palet of first loret; $d$, rudimentary seeond foret; $e$, two views and cross section of caryopsis. $a$, Seale $7.5 ; b-c$, schle 10 . $a-d$, From type specimen of $B$. havardii: $e$, from ariffiths 72 ibi.

densely woolly, acuminate, indiatinctly kceled; lomma, about $6 \mathrm{~mm}$. long, densely woolly, terminating in three equal awns; palet about the same length, woolly on the edges, the two nerves terminating in short awns; rudinent consisting of 3 hispid, nearly equal awns, about $7 \mathrm{~mm}$, long, upon a short, naked stipe 1 to $1.5 \mathrm{~mm}$. long, the central awn and often the lateral with glume-like wings; caryopsis oval, about 2.5 $\mathrm{mm}$. long, $0.9 \mathrm{~mm}$. wide, the scutellum covering nearly the whole ventral surface and curving over the sides onto the doral aurface. (Jigune 51.)

This species attains ifs maximun development in the plateau region of Mexico, where there are large areas covered with it to the exclusion of nearly all else. It also 
forms a large part of the forage upon limited areas in the foothills in southern Arizona. It is easily recognized by its woolly spikes, but may be confused with $B$. eludens.

There is probably a greater difference between young and maturo specimens in this species than in any other of the group. If Kunth's figures are compared with the figures in this text the difference will be easily appreciated. However, my specimens show conclusively that the awns and rudiment develop greatly after anthesis. It is certain that Kunth had immature plants. An examination of the specimens which I am distributing under this name furnish ample proof of the position which is taken here. The plant which Kunth had is also abnormally small. However, this species, in exactly the form described by Kunth, has been seen in abundance in closely grazed areas upon the highlands of Mexico. Upon the highlands of Zacatecas, San Luis Potosí, Aguascalientes, and portions of Jalisco and Oaxaca it is common to find the grass, closely grazed and trampled, forming some semblance of a turf. Under these conditions there is a difference between this form and the common forms of the more arid and stony regions which is comparable to that between the $B$. gracilis of the prairies of the Dakotas and that of the mountains of Arizona. When closely grazed and trampled the culms are short. It was a young plant grown under such conditions that Kunth figured. Conzatti's no. 156 from Oaxaca is a perfect match for the figures mentioned. Portions of Toumey's no. 138, Pringle, "Sandy Plains near Mexican Boundary, Arizona, Aug. 8, 1884," portions of Havard's no. 1, Limpio, Western Texas, July-Sept., 1883, are like the type so far as some of the spikes are concerned. I consider Wilkinson 53, Prngle 410, Lemmon 4635, and 371 , Griffths \& Thornber 2, Nealley 414a and 166, typical of $B$. havardii which is the mature stage of the plant. Many of the spikes of Pringle 410 perfectly match the Humboldt specimen.

\section{HERBARIUM SPECIMENS.}

Arizona: Hitchcock 3702, Patagonia. Griffiths 1829, Mescal; 3440, Santa Rita Forest Reserve. Wilcox, Fort Huachuca. Griftiths \& Thornber 2, Santa Rita Forest Reserve. Lemmon, 371 "S. E. Arizona"; 4635, locality unknown. Toumey 800, 138, Tuceon. Parish 262, Tuckon. Pringle, near Mexican Boundary.

Texas: Nealley 166, Presidio County. Havard 1, Mesquit Canyon, western Texas; 53, Limpio Mountains.

Mexico: Pringle 410, Chihuahua. Wilkinson, Santa Eulalia Plains, Chihuahua. Mearns 1897 near Mexican Boundary Monument No. 82. Palmer 546, Durango. Conzatti 156, Oaxaca. Rose 2532, Huejuquilla, Jalisco; 2782, Plateado, Zacatecas.

22. Bouteloua eludens ep. nov.

DESCRIPTION.

A tall, erect, cespitose perennial, 20 to $50 \mathrm{~cm}$. high, having a general resemblance in its more diminutive forms to $B$. chondrosioides and in some of its taller, more robust forms to hairy-spiked forms of $B$. curtipendula; culms erect, unbranched; blades rather abundant, narrow, and most radical, flat, with serrate edges, often $15 \mathrm{~cm}$. long and about 1 to $1.5 \mathrm{~mm}$. wide; ligule reduced to a fringe of short, white hairs; inflorescence racemose, 6 to $8 \mathrm{~cm}$. long; spikes 10 to 20 , bilaterally arranged on a zigzag axis, but so twisted on the peduncles as to appear unilateral, triangular, about $1 \mathrm{~cm}$. long; spikelets about 5 , consisting of a lower staminate, pistillate, or perfect floret, a middle staminate, pistillate, or perfect or even rudimentary floret, and an upper rudiment varying from a simple prolongation of the rachilla, to a trifid-awned structure with two scales or to a well-developed lemma, or sometimes entirely absent; glumes narrow, densely pubescent, the first acuminate, 5 to $6 \mathrm{~mm}$. long, the second very short-awned and about $1 \mathrm{~mm}$. longer; lemma 6 to $7 \mathrm{~mm}$. long, pubescent, trifid, with 3 winged, short awns; lemma of second floret pubescent, about $10 \mathrm{~mm}$. long, with 3 hairy-hispid awns, the central about $1 \mathrm{~mm}$. louger than the lateral and with projec- 
tions of the lemma between and outside of the awns; palet of lower floret pubeecent above, acuminate, that of the second floret with 2 short awns, both about $6 \mathrm{~mm}$. long; third floret a simple, undivided awn, a rudimentary lemma consisting of 3 long, pubescent, scabrous anns, or a well-developed lemma resembling that of the second floret, but smaller; (aryopsis obovate, about $5 \mathrm{~mm}$. long and $1.5 \mathrm{~mm}$. wide, the scutellum covering nearly the entire ventral suriace, or only about one-half of it. (Plates 78, 79,80, A.)

This species occurs on familiar collecting ground where the most active botanical collectors have worked for years and where the writer collected for about three years before finding it. No specimens of it have been found in any of the herbaria examined. There are literally scores of acres where it forms one-half to three-fourths of the entire vegetation and consequently is, locally, an important eronomic species.

I first collerted the species in the State of Sonora abuut a mille south of Nogales, Arizona, and subsequently in several situations in northern Sonora and southern Arizona. I have seen or collected it on the slopes of the Cananea Mountains, in the Celero Mountains, where it is most abundant, and in the Santa Rita and Santa Catalina Mountains. It is more likely to occur upon southern exposures, especially in the Santa Rita and the Santa Catalina Mountains, where it may be neglected for the more common and well-known Bouteloua chondrosioides. In some situations southeast of Nogales, however, where it grows most luxuriantly, it might be mistaken for a hairyspiked form of $B$. curtipendula. This in itself indicales a striking variation in the general aspect of the species. As indicated in the illustrations, the floral structure is fully as variable.

The type is Griffiths 7269 , collected on southern exposures upon the northern slope of the Santa Rita Mountaing, Arizona, September 17, 1904.

\section{Bouteloua megapotamica (Spreng.) Kuntze.}

Pappophorum megapotamirum Spreng. Syst. Veg. 4 : Cur. Post. 34. 1827. The type was collected by Sello "Rio Grande," Brazil.

Eutriana multiseta Nees, Agrost. Bras. 413. 1820. This was described from a specimen in the Berlin Herbarium collected by Sello at Montevideo. This specimen and a duplicate in the Trinius Herbarium have been examined. See also Kunth, Rév. Gram. 2: 449. pl. 188.1829.

Pappophorum eutrianoides Trin.; Nees, Agrost. Bras. 414. 1829. Mentioned as a synonym under Eutriana multiseta.

Bouteloua mulliseta Griseb. Abh. Ges. Wiss. Göttingen 19: 303. 1879 (Symb. Fl. Argent.). Based upon Eutriana multiseta Nees.

Bouteloua megapotamica Kuntze, Rev. Gen. Pl. $3^{2}: 341$. 1893. Based upon Pappophorum megapotamicum Spreng.

\section{DEBCRIPTION,}

A cespitose, erect or ascending, strongly stoloniferous perennial; eulms about 20 $\mathrm{cm}$. high, erect or geniculate at buse, not branched; sheaths close, striak, smooth; blades rather rigid, abundant below, and often $10 \mathrm{~cm}$. long, but short above, inconspicuously hairy especially on the lower surface, the edges hispid; ligule consisting of

Explanation of Plate 78.-a, Spike of Boutcloua eludens; $b$, spikelet; $c$, lemmia of first floret; $d$, two views of palet of samic, one showing pistillate flower; $e$ and $f$, lemma and palet wit herfoct flower of second florot; $g$, rudimentary lemma of third floret; $h$, two viows and cross section of caryopsis. a-f, Scale 5; $q$, scale $7.5 ; h$, scale 15 . From type spocimen.

Explanation of PLATE 79.-From typo specimen of Boutelona eludcus and photograph taken in Santa Catalina Bountains, Arizong. (5 x 7 No. 3076 Firm Management, U. S. Dept. Agr.)

EXPLAxa Tion or l'LATE 80_-View showing the strong tulty chiracter of Bouleloud eludens, on southern exposures in Sabinio Canyon, Santa Catalina Motustains, Arizona, in the latter part of Septomber. B. Bouteloua trzana from tho vicinity of San $A$ ntonio, Texas, whero this grass is of minor importance, luing usually crowied by ranker spesius. Farther north, in the vicinity of san ingelo, it grows more nourly pure. 


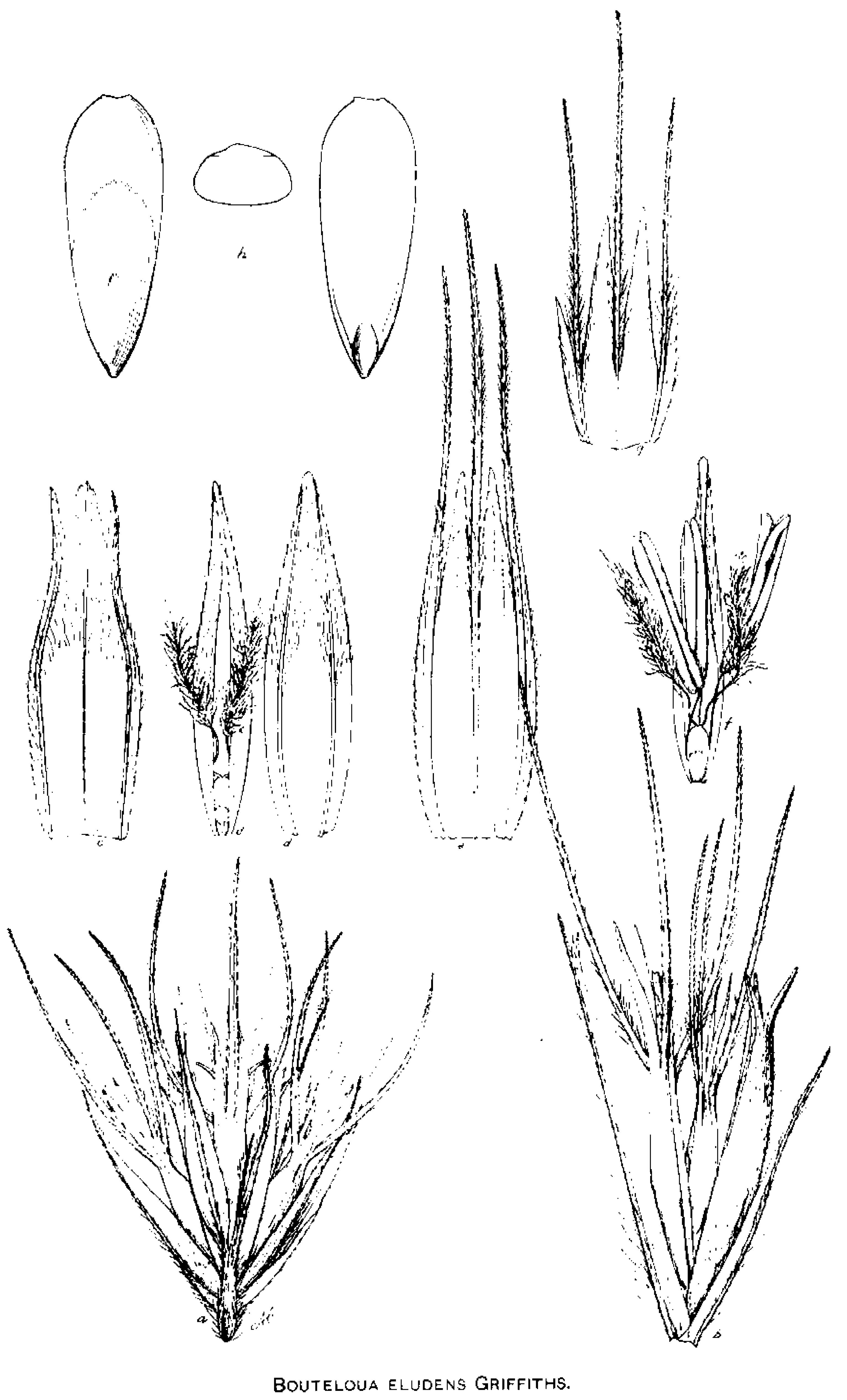




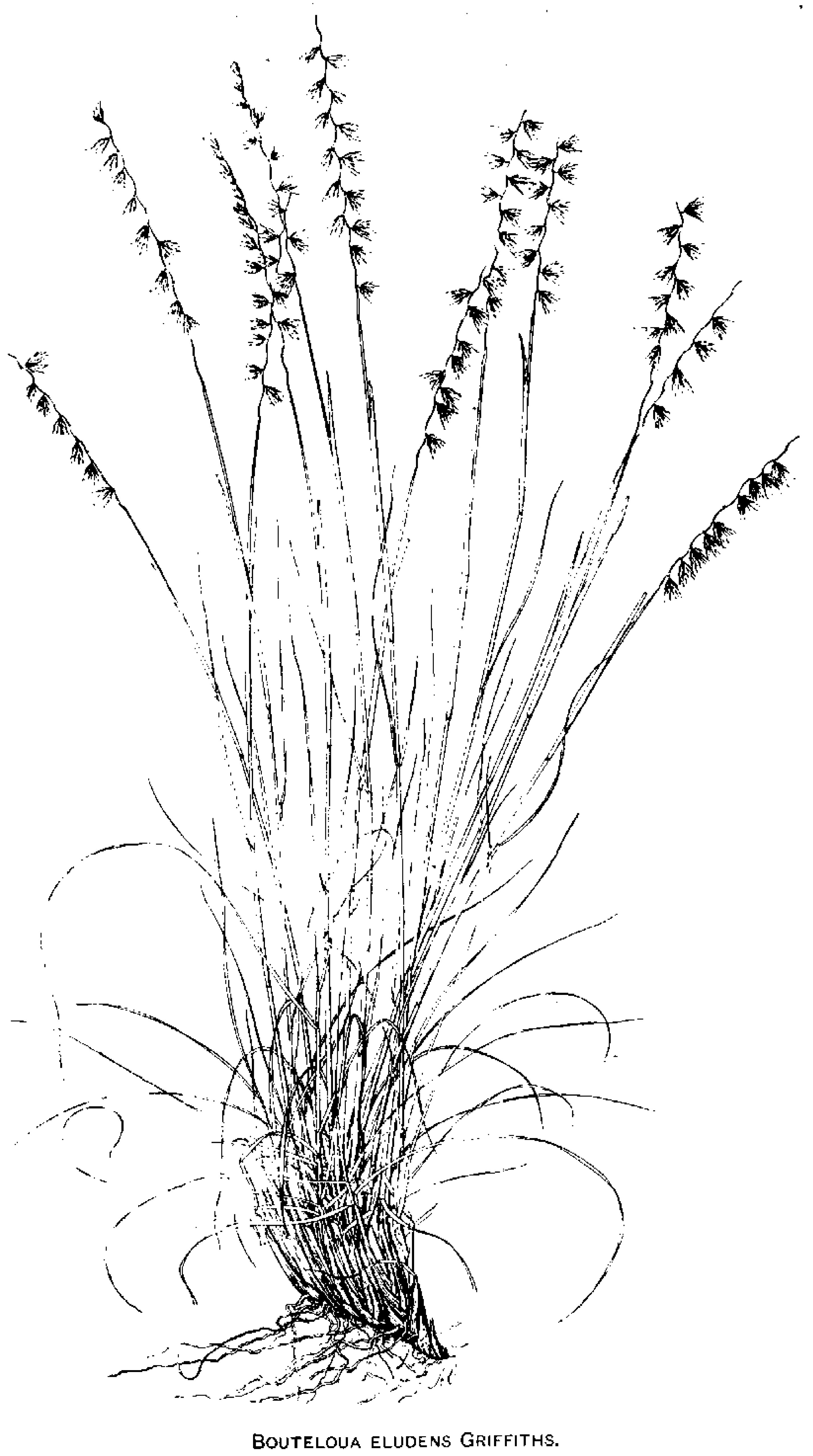




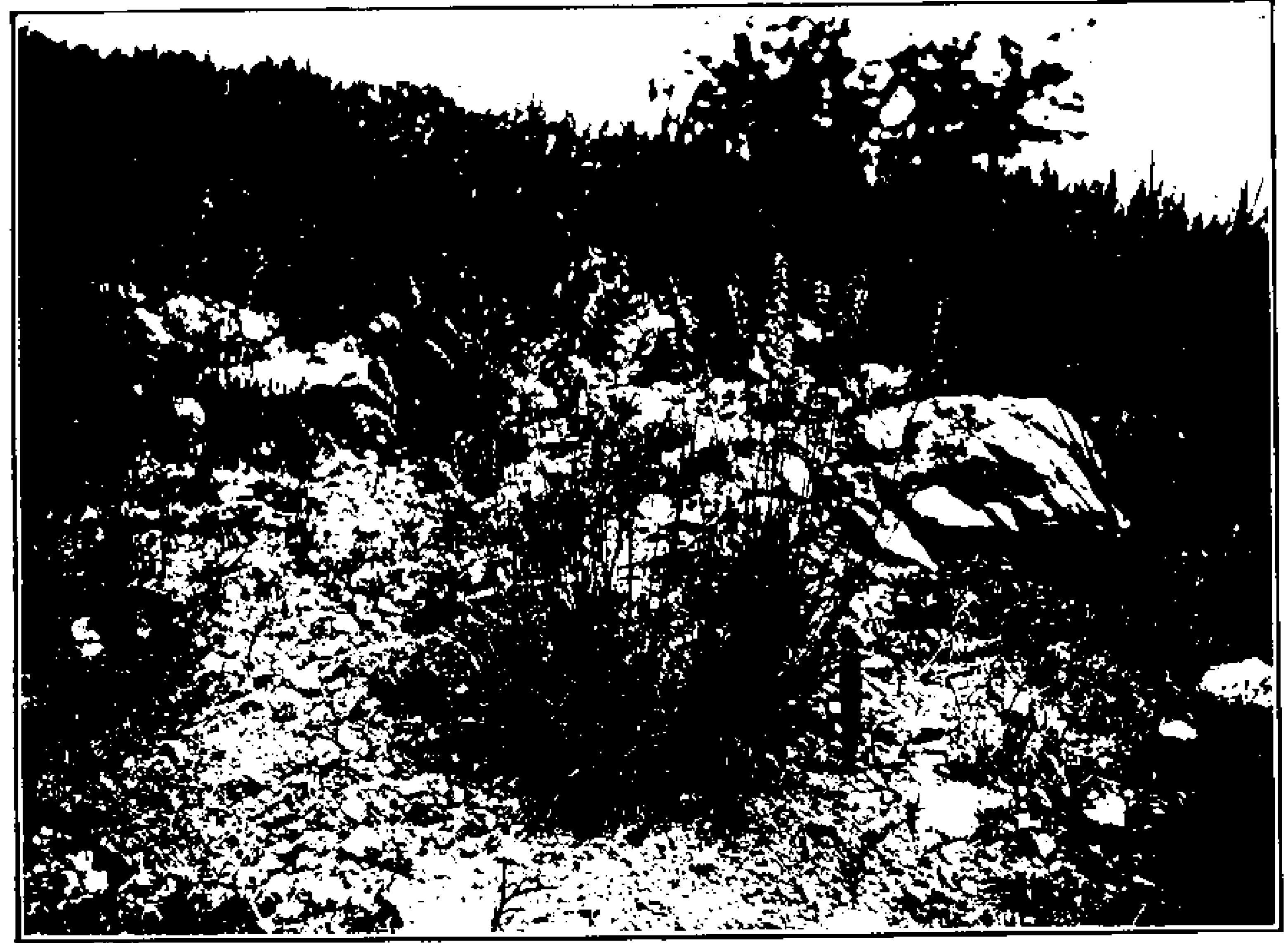

A. Bouteloua eludens Griffiths.

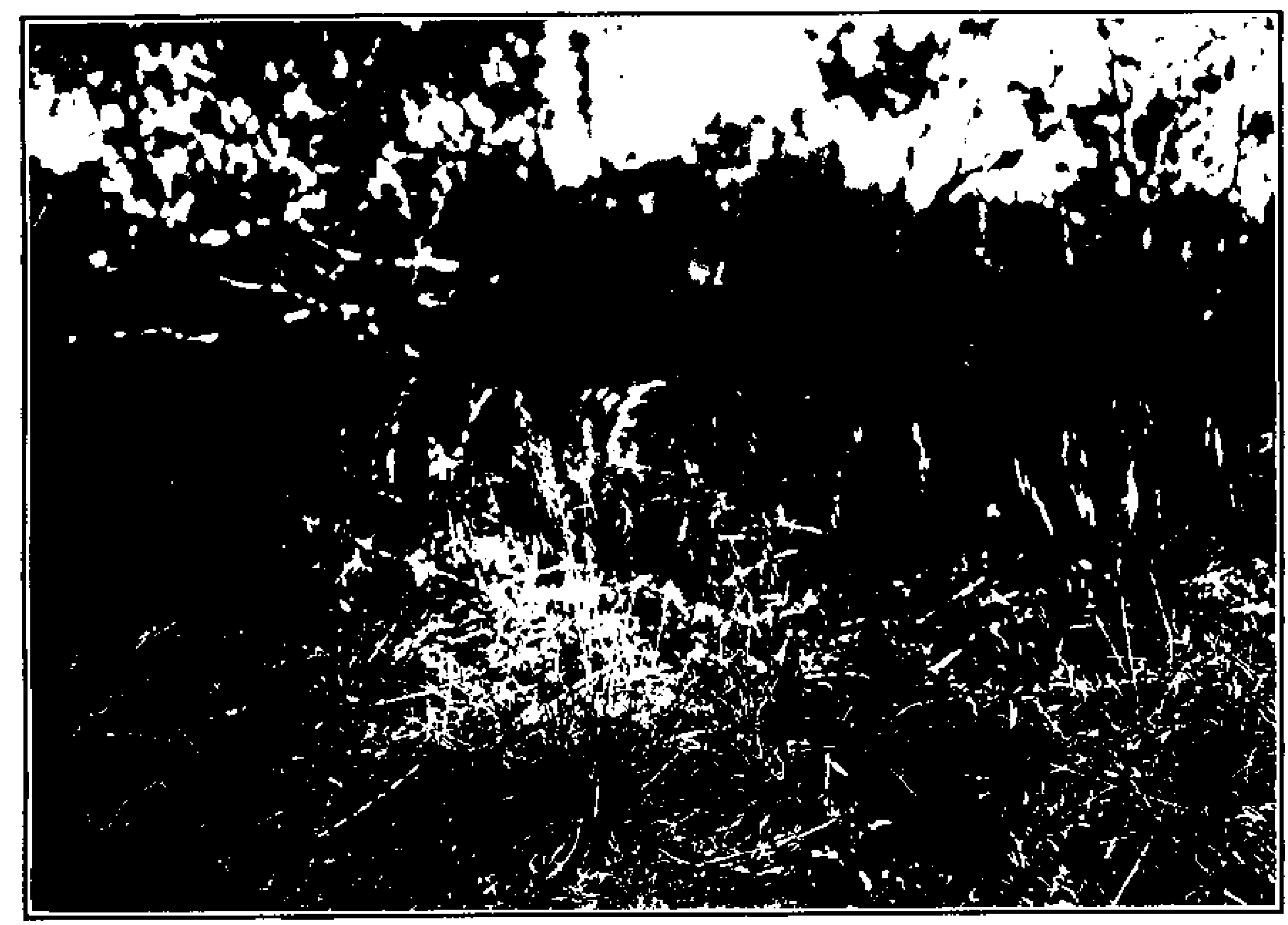

B. Bouteloua texanas. Wats. 
a ring of numerous long, white hairs; spikelets about 5 to 10 , not pectinate, consisting of 1 floret and a rudiment; glumes hispid and hairy-tufted at base, awned, the first $6 \mathrm{~mm}$., the second $10 \mathrm{~mm}$. long, the latter having an abrupt constriction above, the apex eontinued in to two acuminate, awn-like teeth, 0.5 to $1 \mathrm{~mm}$. long, on each side of the central awn; lemma 11 to $12 \mathrm{~mm}$. long including awns, smooth, shining, and bone-like on the back, with 3 hispid, spreading awns about $5 \mathrm{~mm}$. long, the lateral awns nearly equal to the central; palet deeply sulcate on the back and involute on the

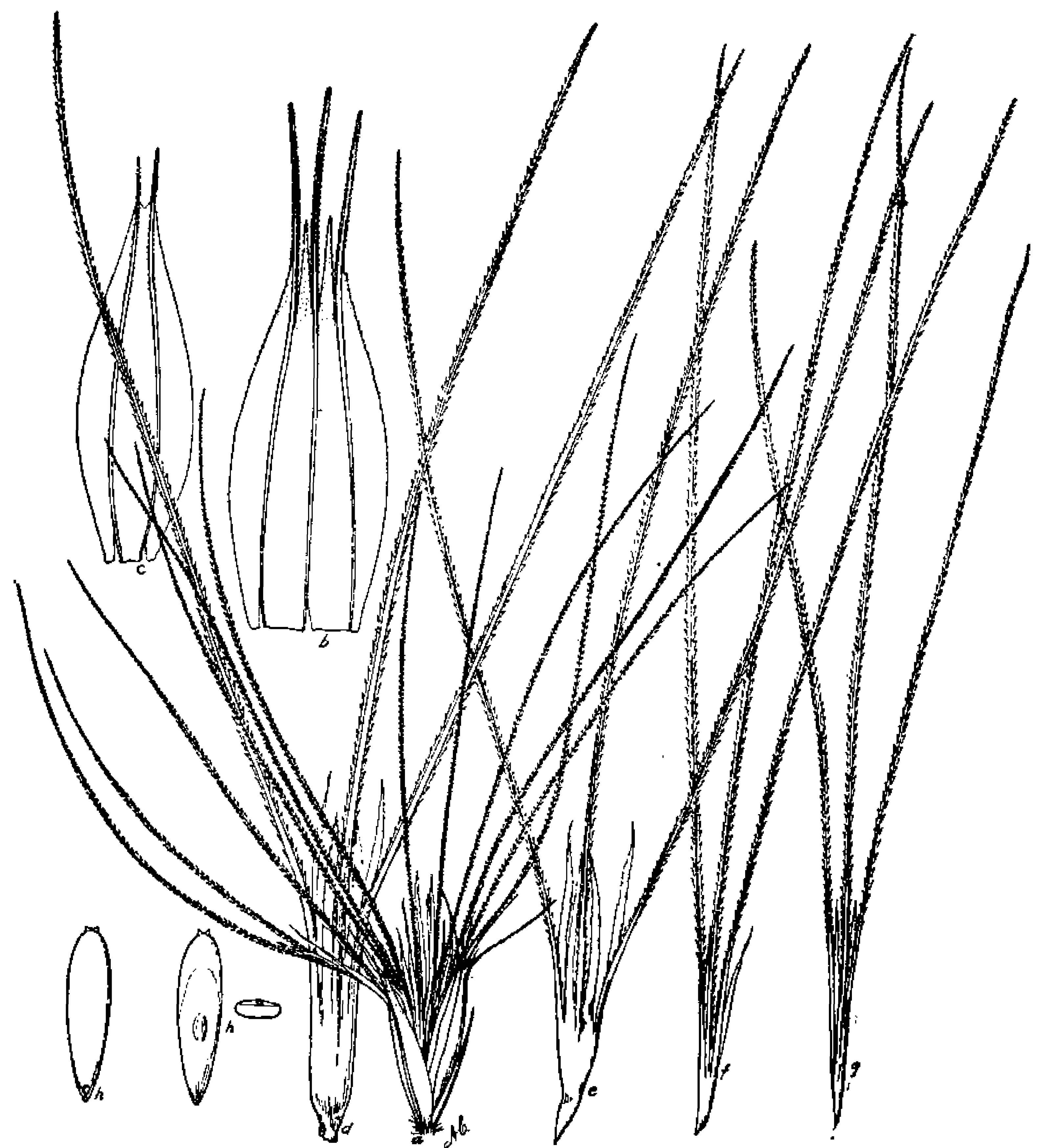

FTG. 52.-Bouteloua megapotamica. $a$, Spikelet; $b, c$, lemma and palet of first floret; $d-g$, rudimentary second, third, fourth, and fifth florets; $h$, two views and cross section of caryopsis. $a$, Scale $2.5 ; b-h$, scale 5. From Arechaocleta, Montevideo.

edges, 2-awned, 8 to $9 \mathrm{~mm}$. long; rudiment consisting of 2 or 3 aborted florets appearing like a cluster of 9 to 12 hispid awns of various degrees of rigidity, interspersed with delicate narrow scales a fourth as long or less; caryopsis cylindrical-obovate, 2 to 2.5 mm. long, the scutellum covering about two-thirds of the ventral surface. (Froure 52.)

Stuckert's no. 27, Kneucker's Gram. Exs. 376, and Arechavaleta from Montevideo, are typical. The latter shows the stoloniferous character beautifully. 


\section{Bouteloua texana S. Wats.}

Bouteloua (Polyodon) texana S. Wats. Proc. Amer. Acad. 18: 196. 1883. The first specimen cited, Brrlandier 1535 , which I arcept as the 1 ype, I have been unable to find in the Gray Herbarium. Duplicates of Hall 771 and Wright 752, whirh ure cited

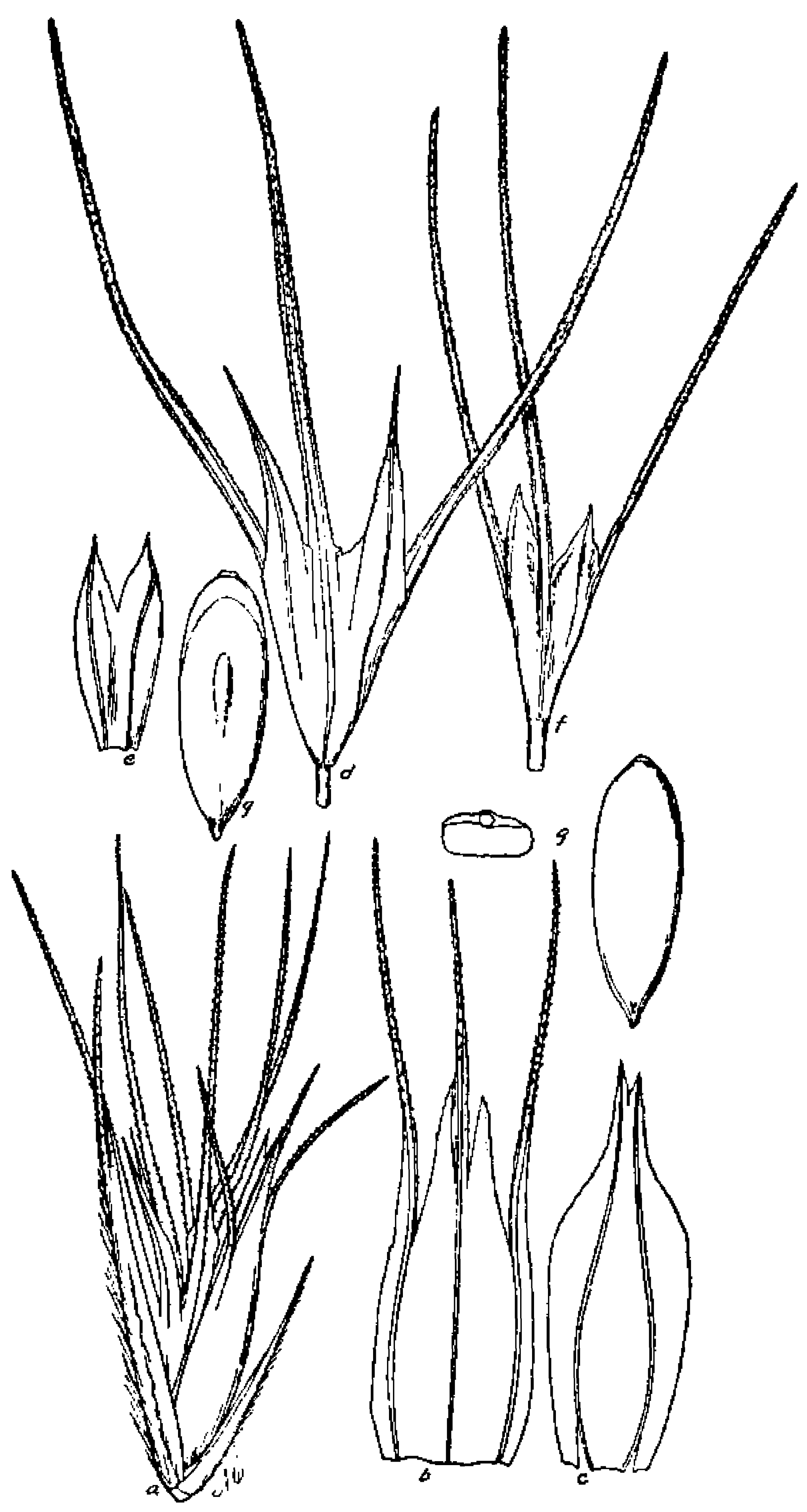

Fia. 53.-Bouteloua texana. $a$, Spikelet; $b, c$, lemma and palet of first floret; $d, e$, rudintentary lemma and palet of second foret; $f$, rudimentary third floret; $g$, two vicws and cross section of caryopsis. $a$, Scale 7.5; $b-g$, scale 10. From Griffith 6370. by Watson, are in the National II erbarium. See also I'. S. Dept. Agr. Div. Agrost. Bull. 7 : 215. f. 197. 1898 .

Polyodon texanus Nash in Small, 1. Southeast. U. S. 138. 1903.

\section{DESCRIPTION.}

An erect, cespitose perennial, 20 to $30 \mathrm{~cm}$. high, usually growing in scattering bunches among other grasses, seldom occupying areas exclusively; culms simple, erect; shouthsuther close, smooth, striate, with a small ligule bearing a few scattered hairs or a ciliate fringe; blades narrow, involute, about $10 \mathrm{~cm}$. long, sparingly pubescent with long, papillose hairs on the edges and especially on the upper surface, the hairs less conspicuous below; inflorescence racemose, 4 to $5 \mathrm{~cm}$. long; spikes 6 to 8 , about $1 \mathrm{~cm}$. long, on short, pubescent peduncles $1 \mathrm{~mm}$. long, easily separable and dropping off entire; spikelets not pectinate, crowded, consisting of a lowerfertile floret and 2 upper rudiments, or of ten the entire spikelet rudimentary; glumes unequal, lanceolate, acuminute, hairy, the first 3 to $4 \mathrm{~mm}$, the sec-

ond about $6 \mathrm{~mm}$. long, short-awned; lemma about $6 \mathrm{~mm}$. long over all, sparingly hairy on the nerves, bearing 3 equal, hispid awns; palet 4 to $5 \mathrm{~mm}$. long; ovate, acuminate or with 2 very short awns; lower rudiment of 3 equal, hispid awng about $7 \mathrm{~mm}$. long, united at their bases by rudimentary glumes, and having a rudimentary, cleft palet 2 to $3 \mathrm{~mm}$. long, the upper rudiment of the same nature but smaller in all its parts and usually with no palet; caryopsis about $2 \mathrm{~mm}$. long, 0.6 $\mathrm{mm}$. wide, flat on the doral surface, the scutellum covering about seven-eighth of the entire ventral surface. (Plate 80, B, facing p. 402. Figure 53.) 
On account of the abundance of root leaves and its bunched nature, this is a rather good forage grass. It does not appear to be able, however, to compete successfully enough with other species to make it of any great importance. The species is common on the southern plains and in the Rio Grande region and is rather important in the vicinity of San Angelo, Texas.

Pringle's no. 9018, distributed as B. bromoides Lag., Nealley 17, Heller 1485, Tracy 8105 , and Reverchon 1135 are representative of the species.

HERBARIUM SPECIMENS.

Texas: Drummond 374. Ball 1110, Chillicothe. Wright 75, Dallas, Letterman, Dallas, August, 1882. Hall 771, Houston Nealley in 1889; 17, Houston. Reverchon 1155, 4215 and 522, Dallas. Heller 1485, Nueces County. Piper, Kingsville. Warburton, Terrell. Tracy 8861 and 8889, Corpus Christi; 8878, Kingsville; 8105, Abilene. Harard, Eagle Pass. Jermy, San Antonio. Smith, Kerrville and San Diego. Bray 329, Llano; 296, Fredericksburg. Bush 244, Fouston; 176, Columbia. Plank 28, Burnet.

Mrxico: Pringle 9018, Diaz, Coahuila.

\section{Bouteloua lophostachya Griseb.}

Bouteloua lophostachya Griseb. Abh. Ges. Wiss. Göttingen 19: 302. 1879 (Symb. Fl. Argent.). The type (Hicronymus's no. 971 from Argentina) in the Grisebach Herbarium, has been examined.

Boutelou nana Griseb. Abh. Ges. Wiss. Göttingen 19: 303. 1879 (Symb. Fl. Argent.). The type in the Grisebach Herbarium (Hieronymus's no. 721, Guazapampa, Argentina) is unqueationably a depauperate form of B. lophostachya. Bouteloua nana is also a younger plant but the panicle and the floral and habit characteristics are in every respect identical with those of Hieronymous 971 .

\section{DESCRIFTION.}

A cespitose, harsh, rigid perennial, with freely branching stems and short, stout rootstalks; sheaths striate, short but completely covering the lower intemodes; blades rigid, divaricate, harsh, keeled, sharply cuspidate-pointerl, 2 to 4 $\mathrm{cm}$. long, abundant below but few above; panicle with 15 to 30 spikes scattered along the main axis, 5 to $10 \mathrm{~cm}$. long, occasionally 2 or 3 spikes together; spikes loosely and

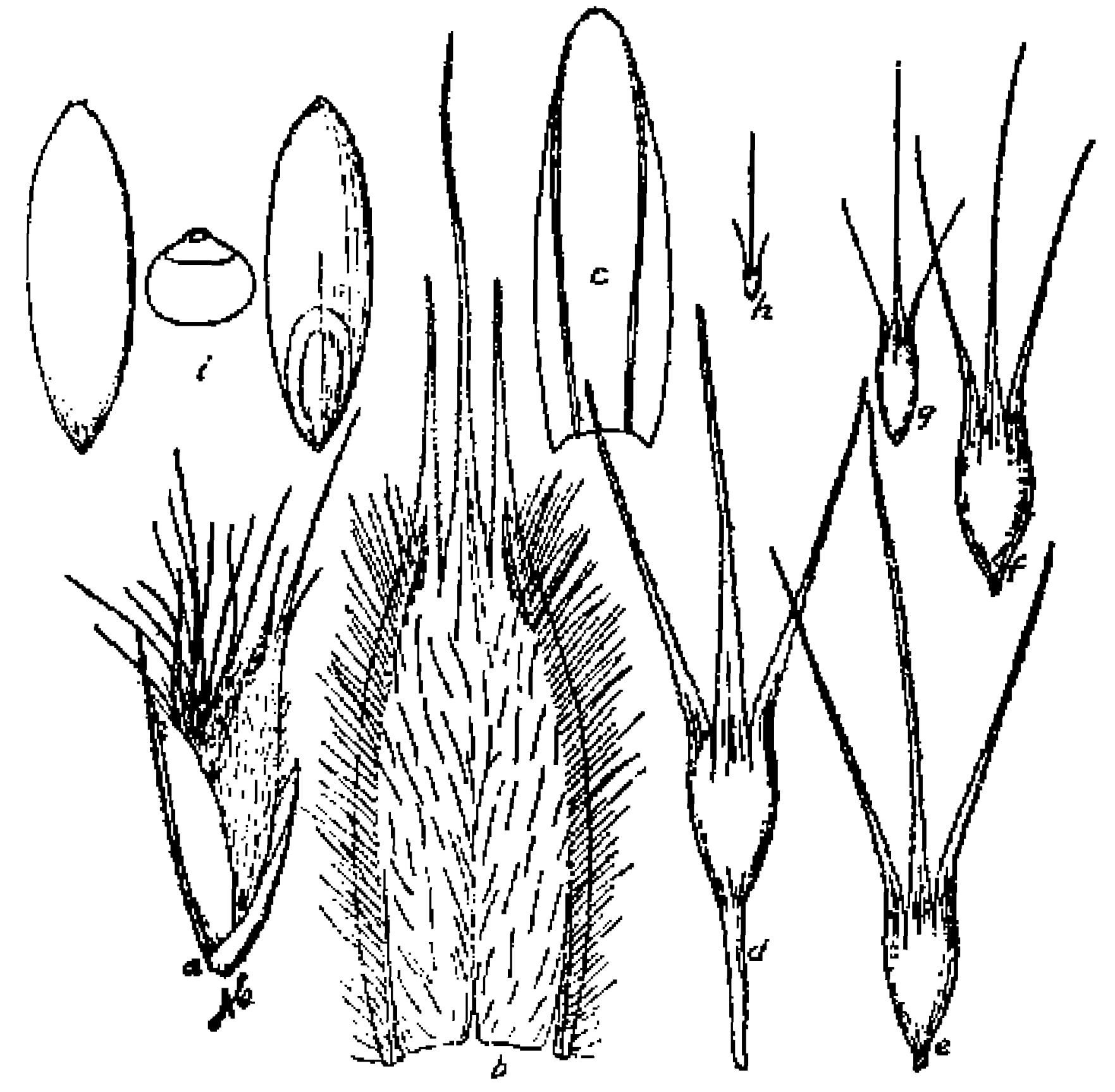

Fia. 54.-Boutelouta lophostachya. a, Spikelet; $b, c$, Jemma and palet of first floret; $d-h$, rudimentary second, third, fourth, filth, and sixth florets; $i$, two vjews and cross sectjon of caryopsis. $a$, Scale 10; $b-i$, scale 15. From Kurtz 12687.

indistinctly pectinate, 1 to $3 \mathrm{~cm}$. long; spikelets 15 to 20 , consisting of a lower perfect floret, with 2 to 4 rudiments above; glumes very slightly scabrous-keeled and shortawned, the first slightly ahorter than the second, about $2 \mathrm{~mm}$. long; lemma pubescent, 3 to $3.5 \mathrm{~mm}$. long, 3-awned, the central awn 2 or more times longer than the lateral; palet obovate, 2-nerved, awnless, about $1.5 \mathrm{~mm}$. long; rudiment consisting of 4 or even 5 well-developed 3-awned scales rosembling the lemma but diminishing 
in size upward, the last sometimes faced by a small 1-awned scale, the whole so congested as to appear like a bunch of awns, and borne upon a short, naked stipe about $1 \mathrm{~mm}$. long; caryopsis $1.25 \mathrm{~mm}$. long, ovate, flattened on the back, the very amall scutellum covering only one-fourth or one-fifth of the ventral surfice. (ligURE 54.)

In general appearance, especially as to inflorescence this specics resembles Leptochloa, but the floral characters are those of Routeloua. The basal portion of the plant resembles that of Muhlenbergia pungens Thurb.

\section{HERBARIUM SPECIMENS.}

SodTh America: Stuckert I0277a, in Ferb. Argent.; 694, in Kneucker's Gram. Exa. from Argentina. Elliott 510, Chile. Benivali 12687 in Kurtz, Herb. Argent.

\section{Bouteloua acuminata (Fourn.).}

Atheropogon acuminatus Fourn. Mex. Pl. 2: 139. 1881. The specimeng cited, Liebmann 583, from Mirador, and Liebmann 584, from Potrero de Consoquitla, Mexico, have not been examined. My knowledge of the ppecies is based upon Palmer's no. 1655 , concerning the identity of which there appears to be no doubt.

\section{DESCRIPTION.}

A stout, erect, smooth, cespitose perennial, resembling $B$. curtipendula in habit and general appearance; culms erect, comparatively stout, about $50 \mathrm{~cm}$. high, leafy

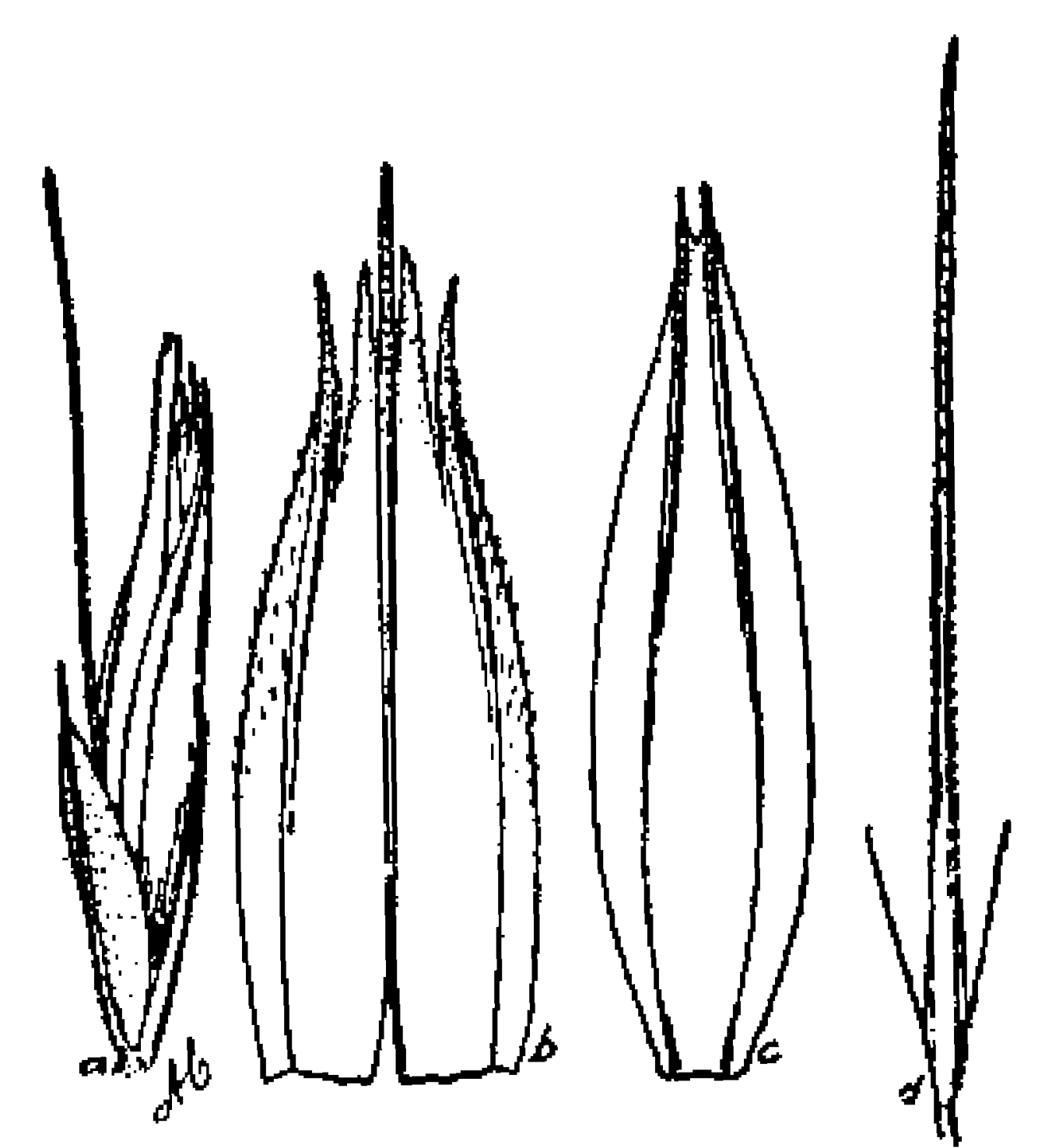

Fig. 55.-Bouteloua acuminata. a, Spikelet; $b, c$, lemma and palet of flrst floret; $d$, rudiment. $a$, Scale $7.5 ; b-d$, scalo 10 . From Palmer 1655.

awm, about $1.5 \mathrm{~mm}$. long; caryopais not seen. (Fraure 55.)

In general habit this very closely resembles $B$. curtipentula, but the spikes are very different, although exactly the same in arrangement. They are smaller and apparently more numerous. Indeed, one might describe the species as $B$. curtipendula with small delicate spikes of rather loosely arranged spikelets, only a fourth the size of those of that well-known apecies.

Palmer's 1655, cited above, of which there are two shects in the National Herbarium, is from Lodiego, Sonora, Mexico, collected October 9 to 15, 1891. It is aaid to grow in large bunches on the mountain sides. 


\section{Bouteloua vaneedeni Pilger.}

Bouteloua vaneedeni Pilger in Urban, Symb. Antill. 6 : 2. 1909; see also Boldingh, Recueil Trav. Bot. Neerland. 6: 7. 1909.

\section{DESCRIPTION,}

An erect, cespitose perennial, 30 to $40 \mathrm{~cm}$. high; sheaths smooth, etriate, close; blades narrow, involute, 6 to $10 \mathrm{~cm}$. long, with a very small ligular ring of white hairs; inflorescence racemose, about 12 to $15 \mathrm{~cm}$. long; spikes small, 4 to $5 \mathrm{~mm}$. long, and only about $1 \mathrm{~mm}$. wide, numerous, about 30 ; spikelets 2 to 4 , in specimens before me only the distal one fully developed, the proximal ones 1-flowered, the distal one with a second floret in the form of a trifid rudiment, the lateral awns very short; glumes smooth, strongly nerved, the first 3 $\mathrm{mm}$., the second $4 \mathrm{~mm}$. long, scarcely awned; lemma smooth, $4 \mathrm{~mm}$. long, bearing awns less than $1 \mathrm{~mm}$. long; palet about the length of its lemma, bearing very short awns. (FIgURE 56.)

I am under obligations to both Doctors Pilger and Boldingh for specimens of this interesting species, collected by the latter (no. $3512 \mathrm{~B}$ ) in the island of Anguilla, Leeward Islands.

In general aspect it appears to be very similar to $B$. curtipendula, while in other respects it even more closely resembles $B$. uniflora. In detail of the spike it bridges over three genera as here limited. The species is interesting in that there are one to three aborted, 1-flowered spikelets below and only one welldeveloped distal spikelet in which the second floret is the normal trifid awn, with, however, the lateral awns so short as to be scarcely visible. The type affords all the knowledge we have

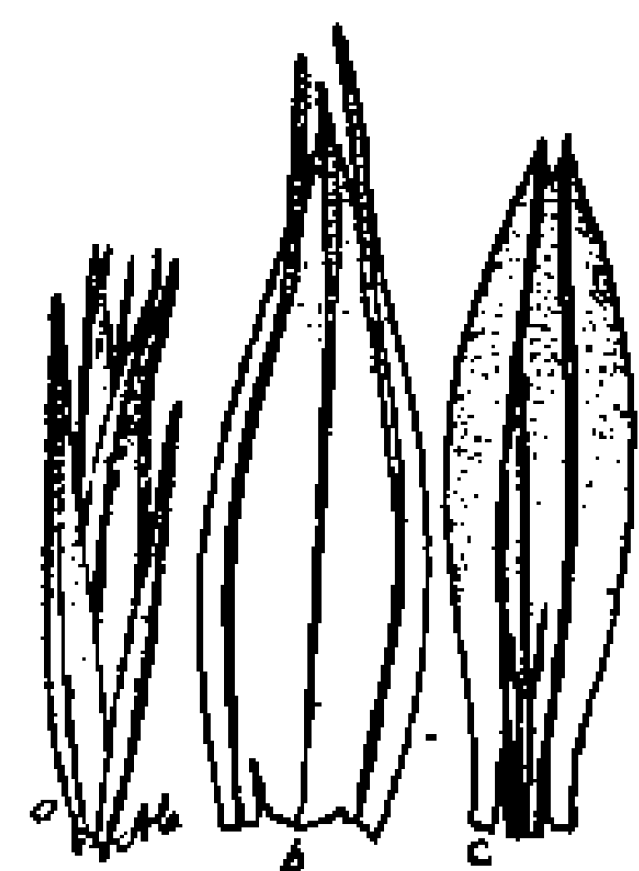

Fro. 56.-Bouteloua vaneadent. a, Bpikelet; $b, c$ lemma and palet with rudiment attached. a, Scale5; $b, c$, scale 7.5. From ty pe specimen. concerning this species and that specimen is immature. It is possible that mature material will necessitate a different disposition of the species.

\section{Bouteloua americana (L.) Scribn.}

Aristida americana L. Amoen. Acad. 5 : 393. 1759; Syst. Nat. ed. 10. 2 : 879.1759. This name has been misapplied by recent authors because of a mizstatement by Munro $a$ concerning its identity. Munro says that $A$. americana "is called $A$. dispersa by Trin.", and that "Kunth has misplaced the Linnean synonym in Eutriana juncifolia." Munro, however, was in error, as is easily shown by an examination of the Linnean plant (see under Bouteloua americana Scribn.); Swartz, Obs. Bot. 41. pl. 2.f. 2.1791. The type, in the Linnæan Herbarium, is a specimen from Jamaica, collected by Patrick Browne.

Triathera americana Desv. Nouv, Bull. Soc. Philom. Paris 2: 188. 1810. Based upon Aristida americana I. See also Roem. \& Schult. Syst. Veg, 2 : 421.1817.

Dineba americana Beauv, Ezs, Agrost. 98, 160. pl. 16.f.1-3.1812. Based upon Aristida americana $\mathrm{L}$.

Heterosteca americana Desv. Journ. de Bot. 1 : 68. 1813. Based upon Aristida americana Swartz.

Bouteloua litigiosa Lag. Gen. \& Sp. Nov. 5. 1816. Baged upon Aristida americana L.

Aristida furcata Poit.; Roem. \& Schult. Syst. Veg. 2:711. 1817. A herbarium name published as a synonym of Dineba americana Beauv.

Euriana juncea Trin. Gram. Unifl. 238. 1824. The specimen in the Trinius Herbarium, collected by Poiteau in Haiti, probably is the Aristida americana of Linnæus. 
I can not, however, from the insufficient fragment before me be certain about it. The leaves are shorter and rather more rigid than in that species.

Eutriana bromoides Trin. Gram. Unifl. 241. 1824, not Kunth 1833. It is more than probable that the species to which Trinius applied this name is $B$. americana, although the first synonym ciled is Alheropogon bromoides Roem. \& Schult. The other two synonyms are Aristida americana $\mathrm{L}$. and Bouteloua litigiosa $\mathrm{Lag}$, and the plant described is from the West Indies. Kunth $a$ has in effect expressed the same view.

Bouteloua elatior Griseb. Fl, Brit. W. Ind. 537. 1864. A portion of the type, Wullschlagel 619 and 660, Antigua, in the Grisebach Herbarium, and a photograph are before me. It is typical of Aristida americana $\mathbf{L}$.

Atheropogon americanus Fourn. Mex. Pl. 2 : 139. 1881. Based upon Aristida americana $\mathrm{L}$.

Bouteloua triathera Benth. Journ. Linn. Soc. Bot. $19: 104$. 1881. Presumably based on Triathera americana Desv.

Bouteloua americana Scribn. Proc. Acad. Phila. 1891:306. 1891. Scribner base日 this name on "Aristida americana Sw. Obs. 41. t. [2.] f. 2. (1791)", on the supposition that this was distinct from $A$. americana L., citing Munro's statement, $b$ that the Linnxan $A$. americana was a true Aristida and the species named Aristida dispersa by Trinius. But, as has been shown, Linnæus's type specimen is a Bouteloua. Swartz does not give this as one of his own species, but gives a reference that leads to Linnats's species. Swartz's illustration shows that he correctly interpreted the species. Hence Scribner's name is, in the last analysis, based on Aristida americana L.

\section{JESCRIPTION.}

A spreading, ascending, or efect, smooth annual; flowering culms mostly erect, freely branched, 20 to $30 \mathrm{~cm}$. high; sheaths striate, smooth, short, close; blades narrow, involute, acuminate, bearing numerous papillose hairs on the edges toward the base, there merging into the very narrow ligular ring; spikes about $2 \mathrm{~cm}$. long, very lax, 3 to 6 or 7 ; spikelets 5 to 7 , about $3 \mathrm{~mm}$. apart, not pectinate but loose, and lying at a narrow angle with the rachis; glumes pronouncedly keeled and strongly hispid, rather abruptly acuminate, the first about $3 \mathrm{~mm}$., the second about $4 \mathrm{~mm}$. long; lemma emooth, shining, and bone-like on the back, 3-awned, the lateral awns less than $1 \mathrm{~mm}$. long, the central projecting about $2 \mathrm{~mm}$. farther; palet 2-norved, with 2 ghort awns, nearly as long as its lemma; rudiment consisting of a modified lemma of 3 awns about $9 \mathrm{~mm}$. long, united into a hard umall scale at the base and faced by a amall 2-nerved rudimentary palet; caryopsis not seen. (FIGUnF 57.)

The group comprising Bouteloua americana and the five species here following is a very difficult one and a great,many names have been applied to the different species owing to a difference of opinion among authors as to generic and specific limitations and to the disregard of the principle of priority as well as to a misundenstanding or neglect of the earlier descriptions.

Bouteloua radicosa as interpreted here is fairly well marked off. It is a large, robust, almost woody based plant with wide, strongly papillose-hairy leaves. Bouteloua repons as here interpreted is not so common as has been supposed. It is easily recognized by its glaucous aspect and by its lack of papillose hairs. The species appears to be confined $t$ s the Pacific coast region of central and southern Mexico.

Boutelou americana also is well characterized by its narrow spikes and annual habit.

It is $B$. filiformis and $B$. heterostega that present the greatest difficulties. They are very diflicult 10 segregate, but that is simply another way of acknowledging that we do not know the species well enough.

a Enum. Pl. 1 : 281. 1833, under E. bromoides.

$b$ See above under Aristida americana $\mathrm{I}$. 
In southern Arizona there is a plant which has heretofore passed for $B$. bromoides, so called. It is erect and has comparatively delicate stems and leaves. In southern Texas, where the soil is more fertile, precipitation more abundant, and shade of shrubbery a more important factor, it has a lighter green color and the culme are more inclined to become geniculate and of ten are decidedly so. In portions of the Mexican highland, where I judge the conditions are similar to those of Texas, upon the ocean slopes and apparently in portions of South and Central America the characteristics of the Texas form are accentuated and the culms are decidedly geniculate and much branched. In the West Indian islands the plant becomea still more modified into an exceedingly variable form which is often depauperate, prostrate, or even slightly stoloniferous. In the entire series I have as yet found no constant floral distinctions except that the West Indian plants often have greatly reduced spikes and prominently modified epikelets, which, however, always have typical ones mixed with them.

As stated above the Arizona-Texas plant has in the past been referred to $B$. bromoides. It extends in a typical form throughout the Mexican highland at least as far as the Isthmus of Tehuantepec. The geniculate Mexican form received the specific name filformis from Fournier and the West Indian plant was called Heterosteca juncifolia by Desvaux. For the present it seems wise to recognize Desvaux's epecies, although unfortunately his name can not be used, and to include under that of Fournier the two forms of the Mexican highland, one of which reaches Arizona and is somewhat modified in Texas. Should it appear wise in the future to separate these two forms the erect one so typical of southern Arizona and the highland of Mexico will have to receive a new name.

\section{HERBARIUM SPECIMENS.}

Wegt IndIEs: Wright 3816, Cuba. Ricksecker 78 , St. Croix. Broadway, Tempe, St. George. Hart 559, Gordon Town, Jamaica. Eggers 687, 5t. Thomas; 5650 , Scarborough, Tabago Island.

Panama: Hitchoock 8409.

There are two specimens, Elliot 138, Granada, and

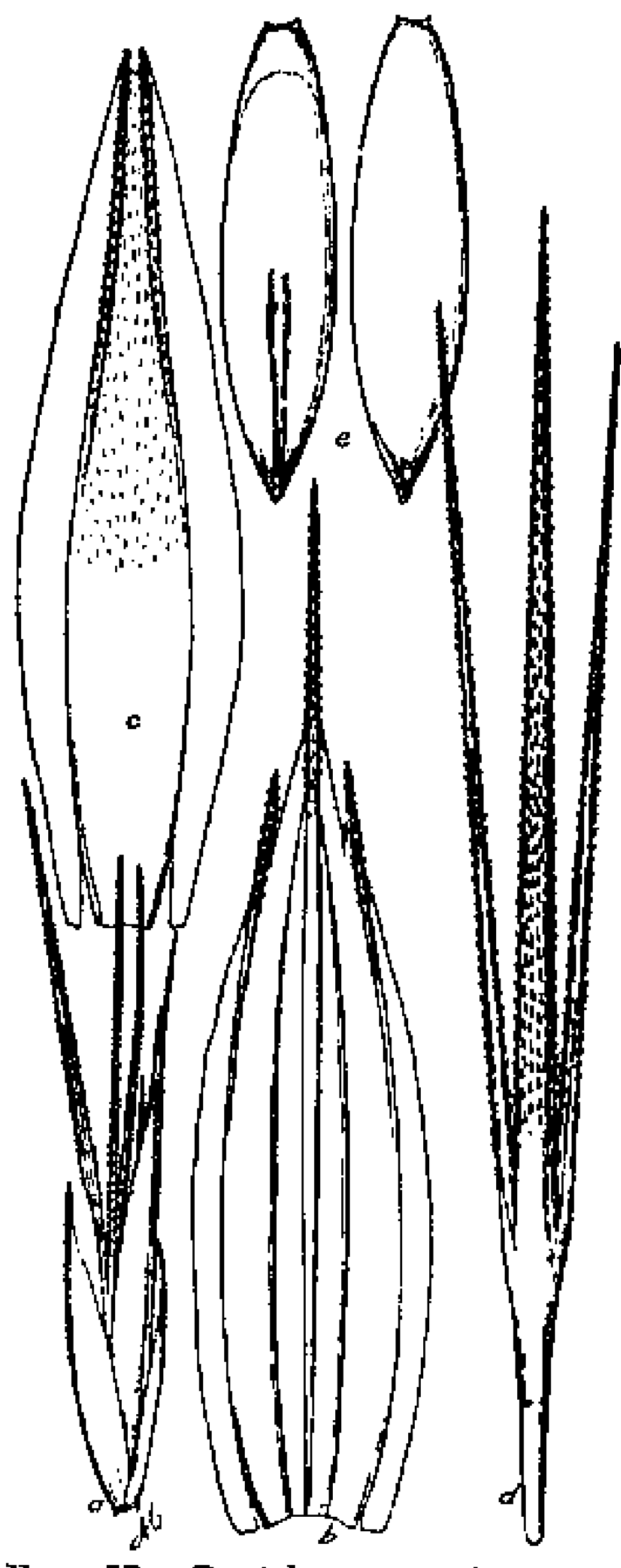

Fig. 57,-Boutcloua americana. a, Spikclet; $b, c$, lemma and palet of first floret: $d$, rudiment; $e_{1}$ two $v$ iews of caryopsis. a, Scale $5 ; b-e_{1}$ scale 10. From Wrighe 3816.

Duss 3160 , Guadaloupe, which appear a little different in habit. They are mainly larger, ranker plants with even laxer spikes and with slightly shorter awns.a

\section{Bouteloua repens (II. B. K.) Scribn. \& Merr.}

Dinebra repens H. B. K. Nov. Gen. \& Sp. 1: 172.pl.52. 1816. "Crescit ad littora Oceani Pacifici prope Acapulco." My interpretation of this is based upon the figures and descriptions.

? Bouteloua bromoides Lag. Gen. \& Sp. Nov. 5. 181G. Iagasca says the plant is from Acapulco, which is the only reason for referring it, to B. repens. He also says it is an annual, but this would be an easy mistake to make. $\Lambda$ later specimen from

a Only the specimens in the National Herbarium are before me, as the last work on this group is done; consequently, citation of specimens can not be as ample as it otherwise might be. 
Lagasca in the herbarium at Munich and one from the herbarium of the Botanical Garden at Madrid, bearing this name in Lagasca's hand, eppikelets of which are before me, possibly should go with $B$. filformis. It seems imposible to identify it. It has

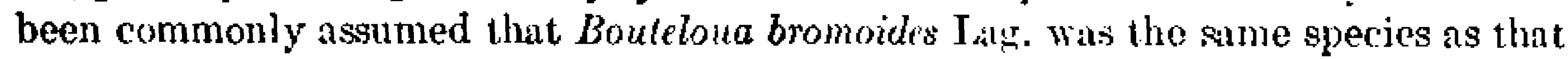
named Dinebra bromoides by Kunth, but Lagasca does not mention Kunth's species and his description does not apply to it.

7 Actinochloa bromoides Roem. \& Schult. Syst. Veg. 2:420. 1817. Based upon Boutelou bromoides Lag.

Atheropogon repens Roem. \& Schult. Syst. Veg. 2: 416. 1817. Based upon Dinebra repens. See also Spreng. Syst. Veg. 1:293. 1825. Fournier a uses this name, but it is very certain that the specimens he cites under it do not belong here.

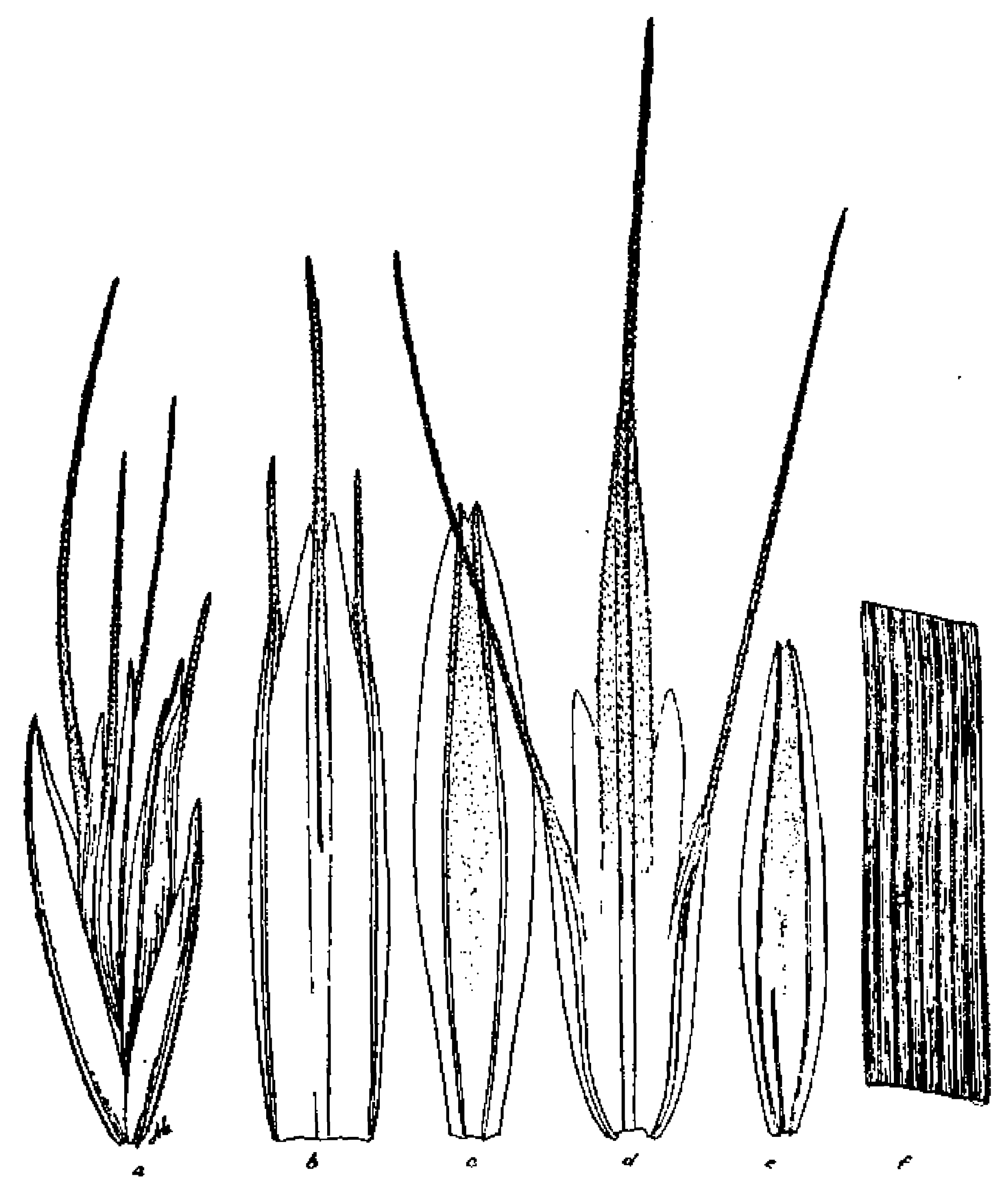

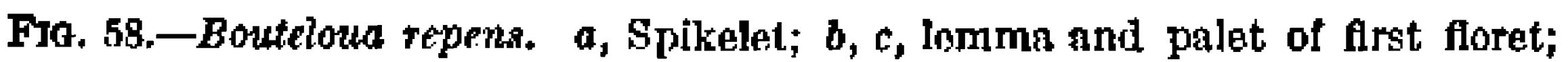
$d, e$, lemma and palet of second flotet (rudiment attuehed to palet): $f$, portion of lear blade. a, Scale 5; $b-e$, scalo $7.5 ; f$, walo 2.5. From Hitchcock 7080 .

Bouteloua repens Scribn. \& Merr. V. S. Dept. Agr. Div. Agrost. Bull, 24 : 26.1891. Based upon Dinebra repens. The former is the first correct combination which has been found, al though the name was applied to a different species.

\section{DESCRIPTION.}

A smooth, glaucous-gray, leafy, stoloniferous, perennial, with erect or ascending and geniculate culms, 50 to $60 \mathrm{~cm}$. high; sheaths striate, smooth, lax on branching culms, close on simple ones, the ligule bearing a few short, white hairs; blades broad, flat or the upper more commonly involute in drying, about $30 \mathrm{~cm}$. long, and $4 \mathrm{~mm}$. wide, conspicuously striate, hispid on the edges; panicle racemose, $10 \mathrm{~cm}$. or more 
long, the basal portion often included in the sheath at anthesis; strikingly colored, with its purple glumes, green lemmas and cinnabar-colored anthers; spikes about 12, rather lax, flattened, $2.5 \mathrm{~cm}$. long including the awns; spikelets 2-flowered with an additional rudiment consisting of a short, naked, awn-like projection beyond the palet of the second floret, and usually included in the fold of the palet; lower floret hermaphrodite, the second staminate or neuter; glumes sharply and hispidly keeled, acuminate but not awned, the second about $7 \mathrm{~mm}$. in length, the first a trifle shorter; lemma of lower floret about $8 \mathrm{~mm}$. long, with 3 short awns, the lateral awns $2 \mathrm{~mm}$, shorter than the central; lemma of upper floret $12 \mathrm{~mm}$. long, lcng-awned, the awns about the .same relative length as in the lower floret, prominently scabrous; palet long, narrow, with 2 very short awns, plicate; caryopsis not seen. (Fioure 58.)

No authentic material of this has been examined. Several of the older authors have listed it from Acapulco, but referred to it various forms of $B$. filiformis. It is distingtished from other species of the group by its large, stout, glaucous aspect and by its lack of papillose hairs on the elges of the leaves. ${ }^{a}$

Hitchcock's no. 7080, from Manzanillo, Mexico, is the only collection that I am able to refer to this species. It grows in large patches so close to the sea that the spray reaches it at high tide.

\section{3). Bouteloua radicosa (Fourn.).}

Dinebra bromoides H. B. K. Nov. Gen. \& Sp. 1 : 172, pl. 51. 1816, not Bouteloua bromoides Lag. 1816. My interpretation of this is based upon the figures and description cited. There has been some confusion concerning this species, due mainly to the misinterpretation of this and also of $D$. repens H. B. K. See also Presl, Rel. Haenk. $1: 292$. 1830. The Haenke specimen in the herbarium of the German University of Prague shows that the species was correctly interpreted by Presl.

Atheropogon bromoides Roem. \& Schult. Syst. Veg. 2: 415. 1817. Based upon Dinebra bromoides H. B. K. See also Spreng. Syst. Veg. 1: 293. 1825. Sprengel cites Aristida americana Swartz as a synonym, but that name does not belong to this species. It appears that Fournier $b$ misinterpreted this. He credits the species to Roemer and Schultes and cites Dinebra bromoides H. B. K. as d synonym. According to my interpretation, however, the specimens which he cites belong to A. fliformis. Galeotti 5704 in the U. S. National Herbarium and the herbarium of the Botanical Garden of Brussels, a Karwinski specimen in the St. Petersburg Botanical Garden, and Schaffner 125 in the Willdenow Herbarium, all belong to A. filiformis. The same is true of Botteri 107 and Liebmann 575. A sheet of the last mentioned specimen in the National Herbarium is from the herbarium of the Museum at Paris and is aid to have been determined by Fournier.

Eutriana bromoides Kunth, R6v. Gram. 1: 95. 1829, not Trinius, 1824. Based upon Dinebra bromoides H. B. K. See also Kunth, Enum. Pl. 1: 281. 1833 and op.cit. 2: 234. pl. 17.f. 4. 1835; also Steud. Syn. PI. Glum. 1 : 216. 1854.c

Nestlera festucaeformis Willd.; Steud. Nom. Bot. ed. 2.2: 192. 1841. A herbarium name only, given as a synonym of Eutriana bromoides.

Heterostega festucaeformis Bonpl.; Fourn. Mex. PI. 2: 140. 1881. A herbarium name cited as a eynonym of Atheropogon bromoides.

Atheropogon radicosus Fourn. Mex. PI. $2: 140.1881$. Bourgeau 450, from Mexico, is the type. This number in the herbaria of the St. Petersburg Botanical Garden, Muséum at Paris, and Botanical Garden of Brusscls and in the U. S. Nationsl Herbarium has been examined. The specimen at Paris is the type.

a See discussion after Bouteloua americana.

b Mex. Pl. 2 : 140.1881.

c For use of this date of publication see Rendle, Journ. Bot. $37: 33.1899$. 


\section{DEBCRIPTION,}

A stout, erect, cespitose, long-lived perennial with stout rhizomatous base, usually in isolated bunches, but occasionally in continuous patches in the southern portion of its range; culms erect, stout, unbranched, 60 to $80 \mathrm{~cm}$. high; sheaths close, strongly striate; blades abundant below and more sparing above, flat, variable in width, mostly 2 to $3 \mathrm{~mm}$. wide, with regularly disposed papillowe hairs on the edges; ligule a ciliate fringe of white hairs, about $1 \mathrm{~mm}$. long; spikes loose, variable, of ten $3 \mathrm{~cm}$. Iong by about $8 \mathrm{~mm}$. wide or sometimes only $1.5 \mathrm{~cm}$. long, and then resembling those of Bouteloua filiformis; spikelets 7 to 10 or sometimes even as much as 11 or $12 \mathrm{~mm}$. long, consisting of 2 florets, the lower perfect, the upper either pistillate or perfect and producing mature seed more often than the lower one; glumes sharply acuminate, the first 4, the second 5 to $6 \mathrm{~mm}$. long; lemma smooth, bone-like, 7 to $8 \mathrm{~mm}$. long, 3-awned, the lateral awns about $1 \mathrm{~mm}$. and the central 2 to $3 \mathrm{~mm}$. long; palet inclosing the caryopsis, scarcely awned, but $1 \mathrm{~mm}$. shorter than the lemma, floret of the same form and texture as that of the lower, 9 to $10 \mathrm{~mm}$. long, with lateral awns 5 to $6 \mathrm{~mm}$. and the central about 1 to $2 \mathrm{~mm}$. longer; palet not differing materially from that of the lower floret; caryopeis about 4 to $5 \mathrm{~mm}$. long, 0.75 to $1 \mathrm{~mm}$. wide, flattened, the scutellum covering four-fifths of the ventral surface. (Plate 81.)

As stated elsewhere this species grows in the upper foothills and mountains and reaches higher altitudes than the closely related $B$. filiformis with which it is commonly mixed. It differs from that species mainly in being a taller, coarser plant throughout. Its leaves are larger and wider, the culms are larger and stouter, the papillose hairs upon the edges of the leaves are more pronounced and obvious, and the spikes are longer. However, upon plants of $B$. radicosa may be found some spikes which might pass for $B$. filiformis, and plants of $B$. filformis grown in exceptionally favorable localities have spikes as Iong as some forms of $B$. radicosa. It is only in consideration of an aggregation of characters that they can well be distinguished, yet they are in my mind perfectly worthy of being kept apart and are easily distinguishable in the field and usually upon the herbarium sheet as well. Bouteloua radicosa is found in rather high situations from Arizona and New Mexico to southern Mexico along the continen ial highland, and extends westward in important quantities especially into Jalisco and Guerrero. ${ }^{a}$ As in B. fliformis there is a great variation in the spikelet. More commonly it is the second floret that is perfect instead of the first. Tonduz $13745 b$ is referred here doubtfully on account of the very small spikes.

\section{HERBARIUM SPECIMENS.}

Artzona: Wilcox, Fort Huachuca in 1894. Jones 562, Bowie. Griffith \& Thomber 220, Santa Rita Mountaine. MacDougal 798, Dos Cabezas. Nealley, Rincon Mountains.

California: Orcutt in 1884.

New Mexico: Wright 2024. Smith, Mangas. Rusby 460, Burro Mountains.

Mexico: Mearns 855, wouth of Bisbee. Tounsend \& Bakr 226, Colonia Garcia. Bourgeau 450. Pringle 1436, Guerrero; 8567, Federal District. Brandegee 2 and 57, Cape region, Lower California. Palmer 1354, Coahuila, Nuevo Jeón; 301 and 188, Rio Blanco; 115a, Chihuahua; 547, Durango. Nelson 2265, San Marcos, Guerrero; 1443 and 1258, valley of Oaxaca; 6258, Colonia Garcia, Chihuahua; 6305, Sierra Madres, Chihuahua. Rose 2672, Colotlan, Jalisco.

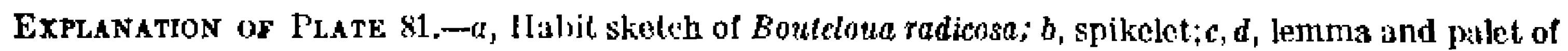
first Dorot; $e$ and $f$, IcI.ma and pitct of second floret; $g$, prolongation of ruchilla; $h, 1$ wo views and erosssection of caryopsis; $i$, portion of leal hlade. $a$, One-fourth natural size; $b$-g, scalo $5 ; h$, scale $7.5 ; i$, seale 2.5 . From Griffiths 7181 and photograph. 


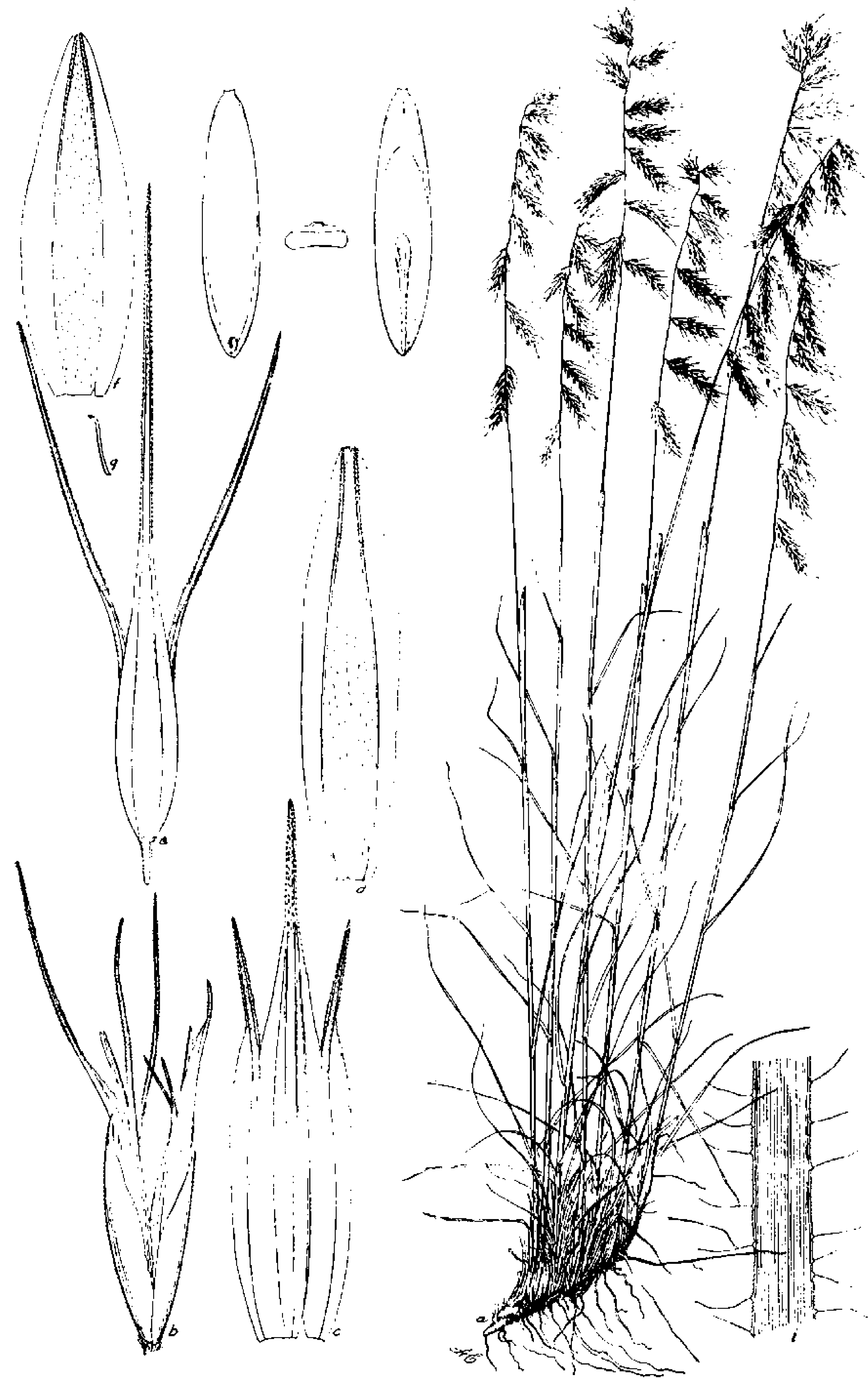

Bouteloua radicosa (Fourn.) Griffiths. 


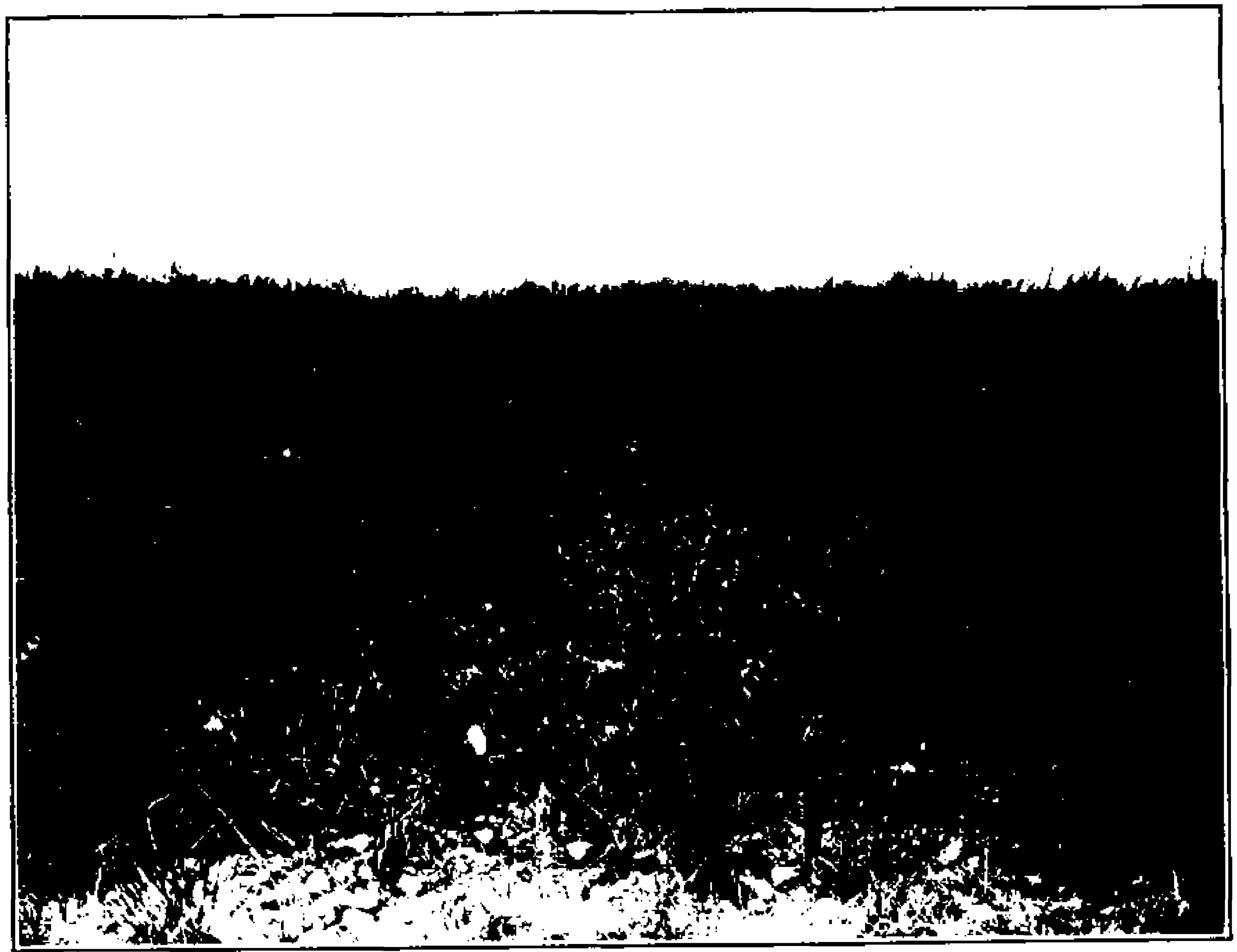

A. Bouttloua filiformis Fourn.' Griffiths.

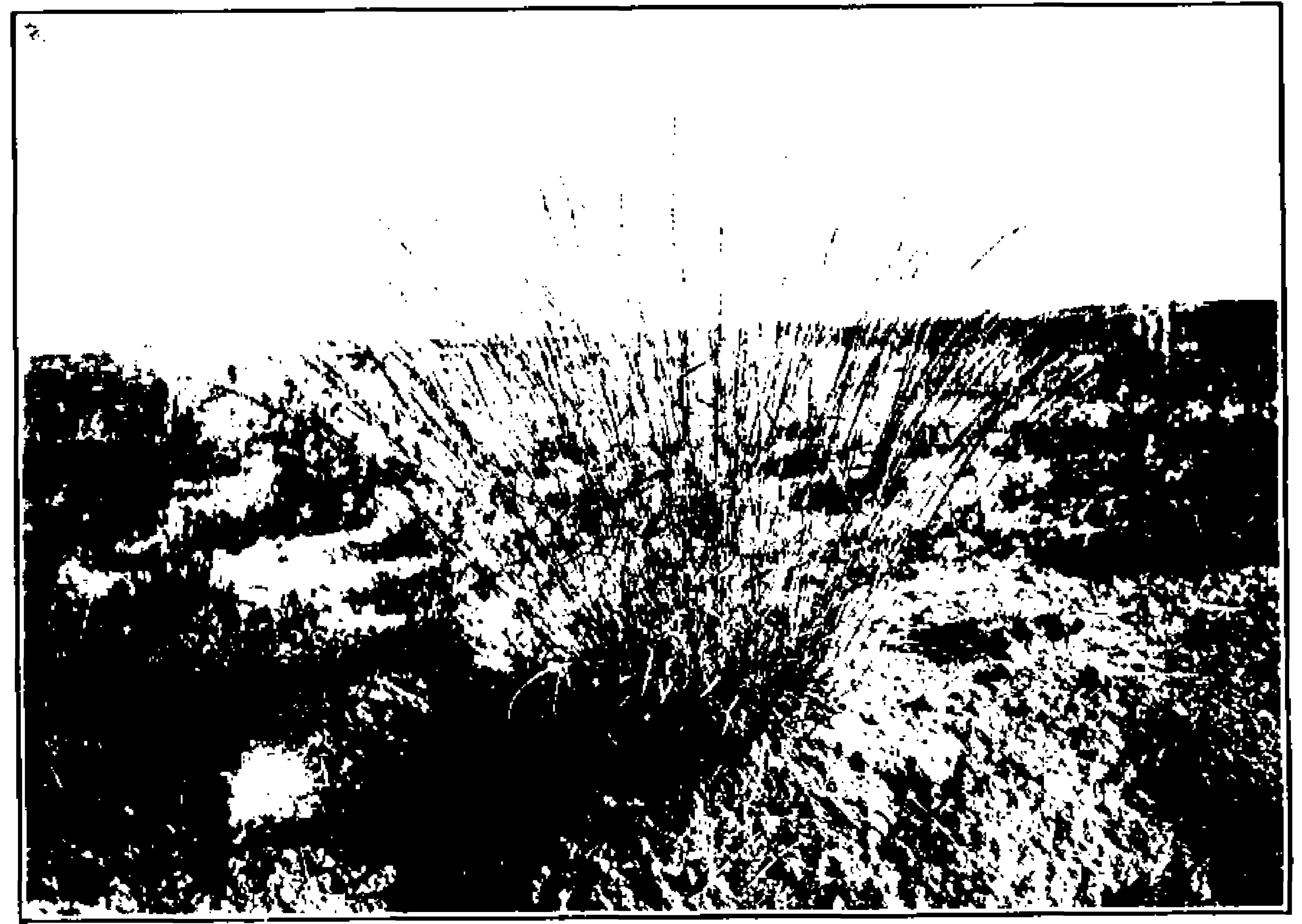

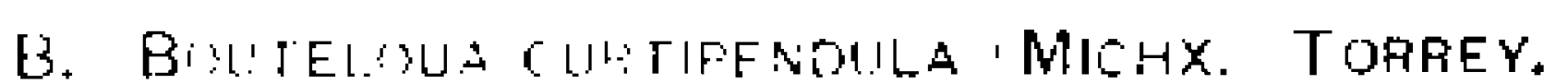




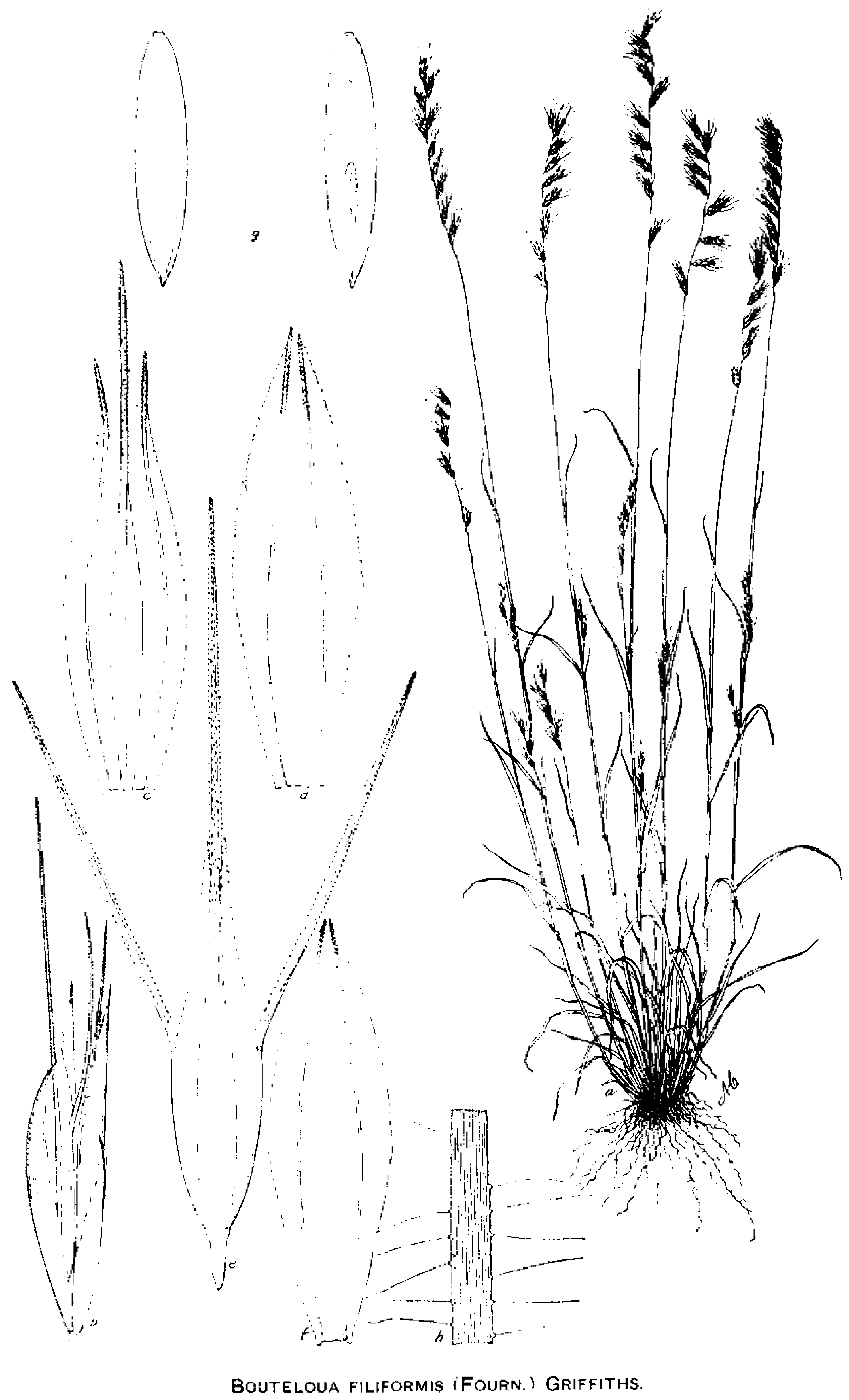




\section{Bouteloua filiformis (Fourn.).}

Atheropogon filiformis Fourn. Mex. Pl. 2: 140. 1881. According to Fournier's description and a specimen cited by Fournier, Liebmann 585, this is a form with geniculate branching culms of what in this country has passed most commonly for $B$. bromoides. Karwinski 991b and Liebmann 585 are in the St. Petersburg Botanical Garden, and the latter number is also in the Berlin Herbarium. The type, Karwinski $991 \mathrm{~b}$, has not been examined.

Vasey $"$ describes and figures this species under the name Bouteloua humboldtiana Kunth.

\section{DESCRIPTION.}

An erect and cespitose or geniculate and spreading perennial, with branching culms and with a more limited root system than $B$. radicosa; culms erect or spreading, unbranched, 30 to $50 \mathrm{~cm}$. high; sheaths smooth, striate, close; blades narrow, 1.5 to 2 mm. wide, delicate, with papillose hairs regularly distributed upon the margin; ligule a ring of white hairs $1 \mathrm{~mm}$. long or less; spikes commonly $8 \mathrm{~mm}$. wide and 15 $\mathrm{mm}$. long, but often $2 \mathrm{~cm}$. long; spikelets about 10, not pectinate, 12 to $14 \mathrm{~mm}$. long, consisting of one perfect lower floret and an upper staminate one; glumes strongly hispidulously keeled, acuminate-pointed but not awned, nearly equal; lemma about $7 \mathrm{~mm}$. long, hispidulous on the nerves toward the apex, 3-nerved, 3-awned, the lateral awns short and the central $1 \mathrm{~mm}$. longer; palet as long as its lemma, toothed but scarcely awned; rudiment consisting of a well-developed staminate floret with a simple, undivided projection of the rachilla $1 \mathrm{~mm}$. long extending above its insertion; lemma of the staminate floret narrower and more conspicuously awned than that of the lower floret, 7 to $8 \mathrm{~mm}$. long over all, the central awn 1 to $2 \mathrm{~mm}$. longer than the lateral, its palet being about the same as that of the perfect floret; caryopsis about 4 $\mathrm{mm}$. long and $1 \mathrm{~mm}$. wide, the scutellum covering about three-fourths of the ventral surface. (Plateg 82, A, 83.)

The species is variable, especially in habit, and has an extensive range from Texas to California and south into South America. In Arizona and the highland of northern Mexico it is an erect plant. $b$

The typical form, that is, the form with geniculate culms growing in favorable situations, is uncommon. There is a slight difference in leafage and color between forms from the United States according ay they grow in the deserts, or upon the more fertile soils of southern Texas. In the latter situation, under cover of brush, the whole plant becomes more lax and has a tendency to become geniculate in habit, like the typical form of the epecies which is familiar to me in western Jalisco.

The following, all from Merico, appear to be typical of the epecies: Liebmann 585, Consoquitla, and 575, valley of Qaxaca. Palmer 1254, Colima; 113, Acapulco; 482, Tamaulipas. Botteri 107, Orizsba; Nelson, Atlixco, July 25 to August 1, 1903.

\section{HERBARIUM SPECIMENS.}

ArIzona: Hitchcock 3499, Tucron; 3692, Patagonia. Griffiths 3441, 3386, Santa Rita Forest Reserve; 1470, Rincon Mountains; 1949, Pearce. Griffiths \& Thornber 3, Santa Rita Forest Reserve. Lemmon 373. Mearns 931, south of Bisbee. Nealley 267, Monmouth. Rothrock 484, Camp Bowie. Davis 562, Clifton. Chase 5515, Tucson.

a U. S. Dept. Agr. Div. Bot. Bull. 12': pl. 40. 1890.

$b$ See discussion under Bouteloua americana.

Explanation of Plate 82.-A, Bouteloua fliformis in lower foothills in southern arizons upon stony ambankments, growing mainly with Leptochloa dubia and $B$. ctrtipendula. B, Bottelona curtipendula, an uncommonly large bunch from near Greaterville, Arizona.

Explanation of l'late 83.-a, Habit sketch of Bouteloua filiformis; $b$, spikelet; $c, d$, lemma and palet of first floret; $e, f$, lemms and palet of second floret; $g$, two views of caryopsis; $h$, portjon of leaf blade. a, One-fourth natural size; $b-f$, scale $5 ; y$, scale $7.5 ; h_{4}$ scale 2.5 . From Griffits 7199 . 
Texas: Havard 89, Eagle Pass.

Mexico: Pringle 2547, valley of Monterey; Palmer 482, Victoria; 1254, Colima; 201, Guaymas; 65, Chihuahua. Liebmann 585, Consoquitla; 575, valley of Oaxaca. Botteri 107, Orizaba. Nelson, Puebla. Hartman 30, Fronteras. Brandegee 29, Miraflores, Lower California. Schumann 1741, Parral. Schaffner 1003, San Luis Potosi. Rose \& Painter 6538, 6821 (in part) valley of Mexico.

Nigaragua: Baker 2319, Granada.

Guatemala: Heyde \& Lux 628 in J. D. Smith, Plant. Guat. Deam 6132, Aguascalientes. Kellerman 4784, Department Amatitlan.

YuCatan: Schott 659, 742, Uxmal; 656, Merida.

Costa Rica: Tonduz 13745.

South America: Pittier 643, State of Cauca, Colombia.

\section{Bouteloua heterostega (Trin.).}

Heterosteca juncifolia Desv. Nouv. Bull. Soc. Philom. Paris 2 : 188. 1810, not Bouteloua juncifolia Lag. 1816. In 1813 Desvaux a reduces this to a synonym of Heterosteca americana, but he was not justified in so doing according to our present conception of epecies. Kunth $b$ appears to have interpreted Desvaux correctly and figures the plant so common in the western portion of the island of Cuba, but made the mistake of including with it Aristida americana L. Desvaux's original description of the genus Heterosteca would exclude the Linnæan plant.

- Boutcloua juncifolia Lag. Gen. \& Sp. Nov. 5. 1816. It seems impossible to determine what this is. Lagasca does not mention Desvax and it does not appear probable to me that he and Desvaux had the same species. Lagasca's type comes from a region to the north of the known distribution of Bouteloua heterostega as here interpreted.

Ictinochloa juncifolia Roem. \& Schult. Syst. Veg. 2: 420. 1817. Based upon Bouteloua juncifolia Lag.

Eutriana heterostega Trin. Gram. Enifl. 242. 1824. Based upon Heterosteca juncifolia Desv.

Atheropogon juncifolius Spreng. Syst. Veg. 1: 294. 1825. Based upon "Eeterostega juncifolia Desv. et Kunth."

Eutriana juncifolia Kunth, Rev. Gram. 1 : 95. 1829. Based upon Heterosteca junciolia Desv.

qEutriana? lagascae Kunth, Rév. Gram. 1: 95. 1829. Based upon Bouteloua juncifolia Lag.

Dineba juncifolia Beauv.; Steud. Nom. Bot. ed. 2. 1: 510. 1840. A name only given as synonym of Eutriana juncifolia.

Bouteloua humboldtiana Griseb. Mem. Amer. Acad. n. ser. 8: 532. 1862. (Pl. Wright. Cub.) The type is Wright 734 in the Grisebach Herbarium. Number 739 is also mentioned. Wright 739 in the herbarium of the Paris Museum has both wide and narrow spiked forms on the same sheet. The species is the wide-spiked form typical of Hetcrosteca juncifolia Desv., of which Kunth gave good figures.b Both numbers are from the island of Cuba. Duplicates of buth numbers as well as of Wright 3816 (described as a different species) are in the Gray Herburium. This should not be confused with Chondrosium humboldianum Kunth, which is based upon Dinebra chondrosioiacs II. B. K.

Bouteloua porphyrantha Wright, Anal. Acud. Cienc. Habana $8: 201$. 1871; Sauv, Fl. Cub. 192. 1873. The type is a part of Wright 739. Duplicates of this number and of the other specimens cited by Grisebach, Wright 734 and 3816, are well represented in

a Journ. de Bot. 1 : 68. 1813.

b H. B. K. Nov, Gen. \& Sp. 1 : 173. pl. 54. 1816. 
the Gray Herbarium and in the National Herbarium. Number 739 in the herbarium of the Paris Muaéum, as stated above, has, on the same sheet, both wide ${ }^{a}$ and narrow $b$ spikes, common in this species.

Atheropogon americanus depauperata[us] Fourn. Mex. Pl, 2: 139. 1881. Fournier cites Bouteloua juncifolia Lag. and Eutriana lagascae Kunth as synonyms. He mentions two specimens, the first is one from Karwinski in the St. Petersburg Herbarium with neither number nor locality; the other is Wright 739 . It is evident from his description and the citation of the last specimen that he had in mind Bouteloua porphyrantha Wright. He is evidently wrong in his interpretation of Lagasca.

Heterosteca rhadina Nash, Bull. Torrey Club 30 : 386. 1903. Heller's no. 6057, near Ponce, Porto Rico, in the New York Botanical Garden, is the type. Duplicates are widely distributed. Some of these duplicates show the same facts exhibited by Wright 739 in the herbarium of the Paris Muséum.

\section{DEBCRIPTION .}

Plants mostly low, spreading, sometimes erect, but mostly reclined, and often nearly prostrate and stoloniferous, perennisl; culms freely branching; spikes 4 to 10 , variable, 1.5 to $3 \mathrm{~cm}$. long, 2 to $6 \mathrm{~mm}$. wide; spikelets 4 to 7 , about $12 \mathrm{~mm}$. long including awns, 2-flowered, the lower perfect or pistillate, the upper staminate; glumes nearly equal, scabrous-keeled; lemma of lower floret shortawned, with lateral awns ehorter than the central, smooth, coriaceous, about $8 \mathrm{~mm}$. long; lemma of upper floret smooth, coriaceous 10 to $12 \mathrm{~mm}$. long, with long awns, the lateral slightly shorter than the central; palet smooth, $8 \mathrm{~mm}$. long very short-awned sulcate, on the back between the two nerves,

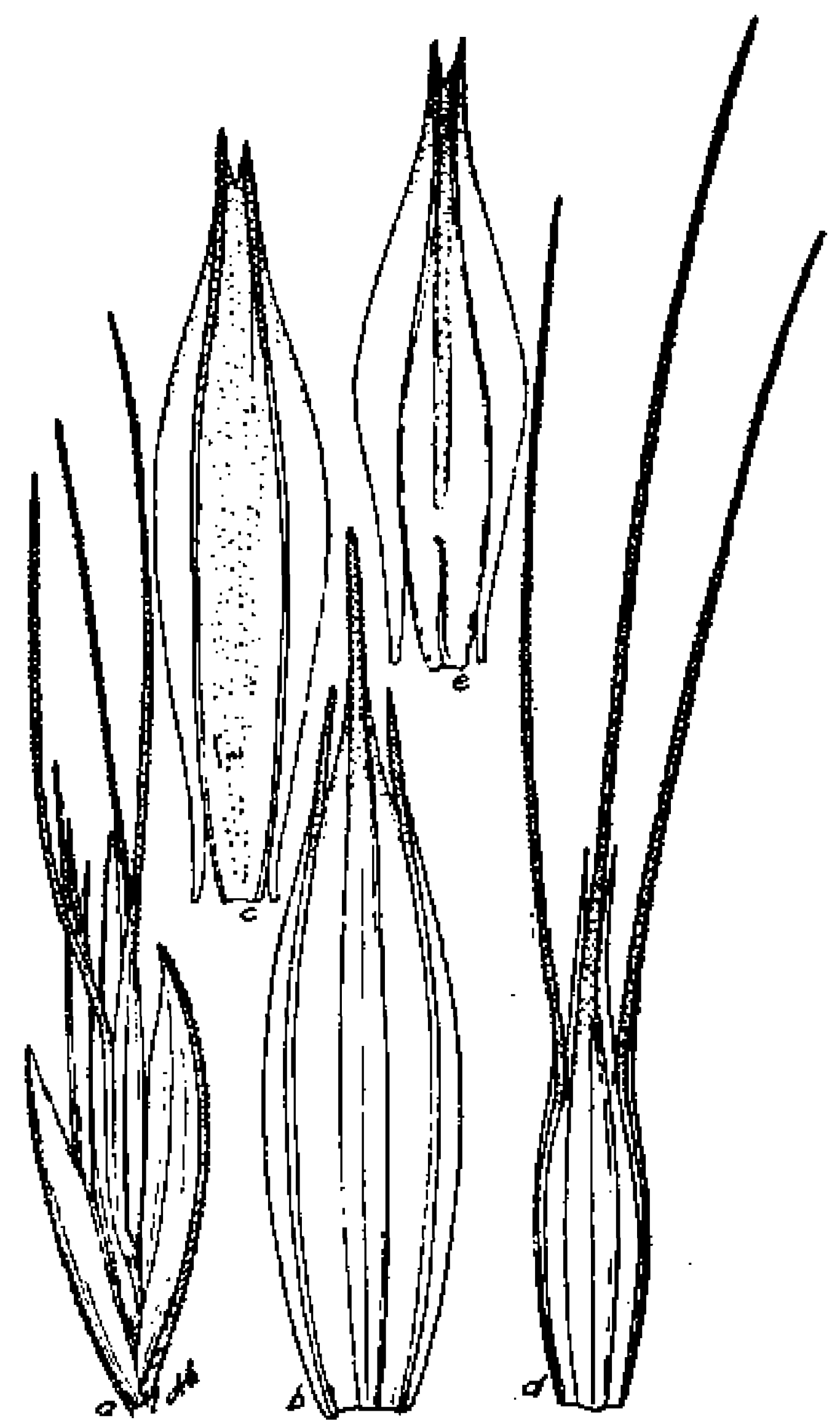

Fic. 59.-Bouteloua heterostega. $a$, Spikelet; $b$, $c$, lemma and palet of flrst floret; $d, e$, lemma und pulet of second floret (rudiment attached to palet). $a$, seale 5; $b-\epsilon$, scale 7.5. From León 861. the edges involute; caryopsis about $3 \mathrm{~mm}$. long, $0.7 \mathrm{~mm}$. wide, pointed below and contracted above (immature). (FIGURe 59.)

The species, as it occurs in the West Indies, is very variable in every particular. The spike and spikelet characters are especially subject to variation. The above characterization is drawn from Brother León's no. 861 in so far as epike and details are concerned, amended from Curtiss (West Indian Plants) 546 and others, as to plant characters. The Curtiss specimen in the National Herbarium shows two distinct forms of spikes, one as here described and figured, and the other resembling $B$. americana. Kunth figured $c$ the wide-spiked form. The majority of the specimens show a true perennial character, while $B$. americana is evidently an annual. In habit and general aspect the species presents all sorts of variations from an erect plant, with branching culms, to a low prostrate plant, with often long-geniculate to prostrate

a Bouteloua humboldtiana Grigeb.

b Bouteloua porphyrantha Wright.

c H. B. K. Nov. Gen. \& Sp. 1 : 173. pl. 54. 1816. 
culms, having profuse proliferations at each node. Rooling often orcurs on these nodes making tho plants appear stoloniferous, and a short scaly rootstock is sometimes seen, as in the IIitcheock specimen collected at Triscornia, Cuba, March 23, 1906. The Tracy specimen, mentioned below, h:s spikes with very long awns closely resembling those of $B$. radicosa. See discussion under $B$. americana.

\section{HERBARIUM BPECIMENS.}

West Indes: Wright 739, Cuba; Hitchrock 452, Triscornia, Cuba; 460, Playa de Cojimar, Cuba. Tracy 9088, Triscornia. Sintenis 2469, 2203, and 1959, Porto

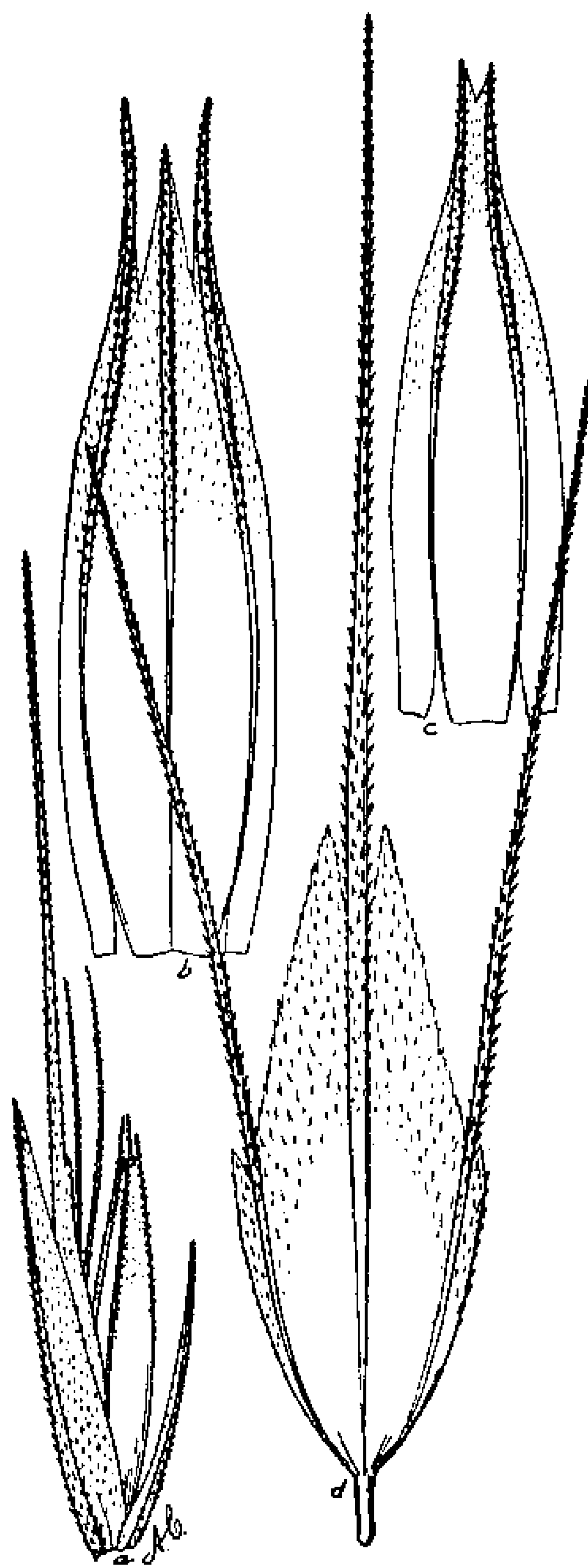

Fo. 60.-Boulcloua disticha. a, Spikele1; $b, c$, lemmantml palet of first floret; $d$, rudimentary floret. $a$, Scale $5 ; b-d$, scale 10 . From Schott $7 \notin 1$ in Field Museurn Herb.

Eascicled, the lower beingr small an usually with long-awned lemmas so disposed as to make the npike appear bilaterally 1326, Martinique. Heller 6057, Porto Rico. León 293 and 861. Habana.

33. Bouteloua disticha (П. B. K.) Benth.

Dineba dicaricala hitulv. Ess. Arrost. 160. 1812. No description is given; the name appears only in the index, where in bis private copy of this work Beauvois has writien "=disticha," which I interpret to mean Polyodon distichum 1I. B. K.

Polyodon distichum II. B. K. Nov. Gen. \& Sp. 1:175. $p l$. 5.5. 1816. I consiler the secimens seen to be casily identified from Kunth's figures and description.

Eatriana polyodon Trin. Gram. Inifl. 242. 1824. Bised upon Polyodon distichum II, B. K.

Atheropogon distichus spreng. Syst. Veg. 1:294. 1825. Based upon f'olyodon distichum H. B. K.

Bouteloua disticha Benth. Journ. Linn. Soc. Bot. 19:105. 1881. Bissed upon Polyodon distichum II. 13. K. See also Field Mus. Bot. 3:53. 1903 .

DESCRIPTIOX.

An erect, cespitese perennial, about 30 cm. high, with sparingly branched culms; sheths striatc, papillose-huiry, rather loose; blades comparatively broad, fat, scabrous on the edges, with conspicuous papillose hairs, especially toward the base and on the edges; ligule a rather conspicuous collar with a fringe of ciliule hair:; inflorescence racemose; spiker about 25 in number; bilatcral but sometimes appearing unilateral, about 1.5 cm, long including awns, spikelets 5 to 8 , not pertinite, but more or less l mostly rudimentary, but the upper more

Rico, Curtiss 516, I Iabana, Cuba. Duss 
eymmetrical; glumes acabrous-keeled, the first reduced nearly to an awn, $5 \mathrm{~mm}$. long, the aecond wider, 7 to $8 \mathrm{~mm}$. long; lemma 5 to $6 \mathrm{~mm}$. long, amooth, with 3 ghort awns, the lateral awns slightly longer than the central; upper floret simply a 3-awned rudiment with a few scales at base or a well-developed perfect floret, but always, except in the lower spikes, bearing a long central awn, the lemma, including awn, 10 to $14 \mathrm{~mm}$. long, the lateral awns often not more than 6 or $7 \mathrm{~mm}$. long. (Figure 60.)

The first specimen of this epecies which I have recognized is Schott 741 , in the herbarium of the Field Museum of Natural History. The floral characters of $B$. disticha are exceedingly variable, as is true of many of the species of this group. The description is drawn from the upper spikelets. The lower ones are small and often staminate only, the rudiment being reduced to three imperfectly developed, short awns.

The species is exceedingly rare in collections. The chief diagnostic character is the inflorescence and the apparent bilateral arrangement of the spikelets, which is admirably brought out in Kunth's figures.

Besides the Schott specimen the following are typical: Curtiss 537, from Cuba; Pittier 10374, from Costa Rica; and León 299, from Cuba. Pittier 2537, Canal Zone, is a geniculate form with branching culms.

\section{Bouteloua pilosa (Hook.) Benth.}

Eutriana pilosa Hook. f. Trans, Linn. Soc. Bot. 20: 173. 1851; Steud. Syn. Pl. Glum. 1: 216. 1854. The Macrae specimen from Mlbemarle Island, cited by Hooker, has not been examined. My knowledge is based upon Andersson 46, from Galapagos, and Fendler 2521, from Venezuela, in the Grisebach Herbarium. More recently many fine specimens have been examined in the Gray Herbarium from the Hopkins Galapagos Expedition (Snodgrass \& Heller 655).

Eutriana gracilis Hook. f. Trans. Linn. Soc. Bot. $20: 175$. 1851, not Bouteloua gracilis Hook. $a$ nor Lagasca. $b$ The type of this species has been examined through the courtesy of the director of the Royal Botanic Gardens of Kew, England.

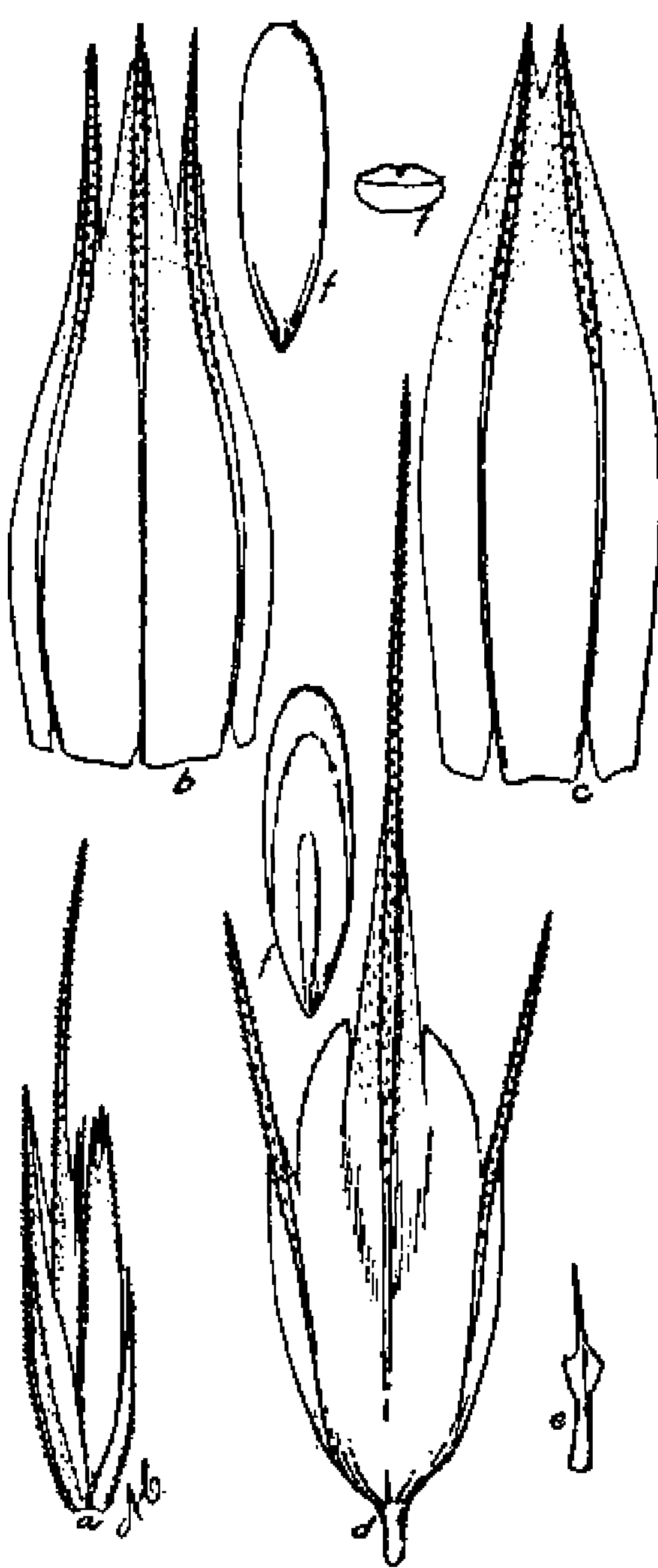

Fig. 61.-Bouteloua pilasa. a, Bpilrelet; $b$, $c$, Jemme and palet of first floret; $d$, rudimentary second foret; $c$, rudimentary floret of lowermost spikelet; $f$, two views and cross section of caryopsis. a, Scale 5; b-f, scale 10. From Snodgrasa to Hellet 655 in Gray Herb.

Bouteloua pilosa Benth.; Wats. Proc. Amer. Acad. 18: 179, 1883. Based upon Eutriana pilosa Hook. f.

\section{DEBCRIPTION.}

An erect, cespitose, smooth annual(?) 20 to $40 \mathrm{~cm}$. high; culms slender, often branching; sheaths close; blades flat, thin, often $10 \mathrm{~cm}$. long, the ligule an inconspicuous ring of short hairs; inflorescence racemose, 10 to $20 \mathrm{~cm}$. long; spikes variable, from 15 to 35 , bilateral, on a zigzag rachis, but usually appearing unilateral; 
spikelets 3 to 5 , consisting of a lower perfect floret and an upper rudiment; glumes narrow, hispid, keeled, the first about $3 \mathrm{~mm}$., and the second about $5 \mathrm{~mm}$. long, smooth, with 3 short, hispid awns, the central awn not over $0.5 \mathrm{~mm}$. longer than the lateral; palet the same length as its lemma, with two short awns from the two nerves; rudiment usually consisting of a single 3-awned lemma, the central awn being by far the most important, often 9 to $10 \mathrm{~mm}$. long, the lateral awns only $2 \mathrm{~mm}$. long, infolded; caryopsis flattened, $1.75 \mathrm{~mm}$. long, $0.5 \mathrm{~mm}$. Wide, the small scutellum covering only about one-third of the ventral surface. (FIGURE 61.)

The description is drawn from Snodgrass \& Ifller 393, James Island, Galapagos, April, 1899. This appears to be a good, average specimen, although it does not cover all of the many variations. The spikelet described is from the middle of the spike. In the lower spikelet the rudiment is usually much smaller than described, at times even reduced to a single awn half as long as the perfect floret. It is exceedingly variable and is more closely related to $B$. cartipendula than to any other species. The Hopkins Galapagos Expedition furnished a fine series of specimens, the best

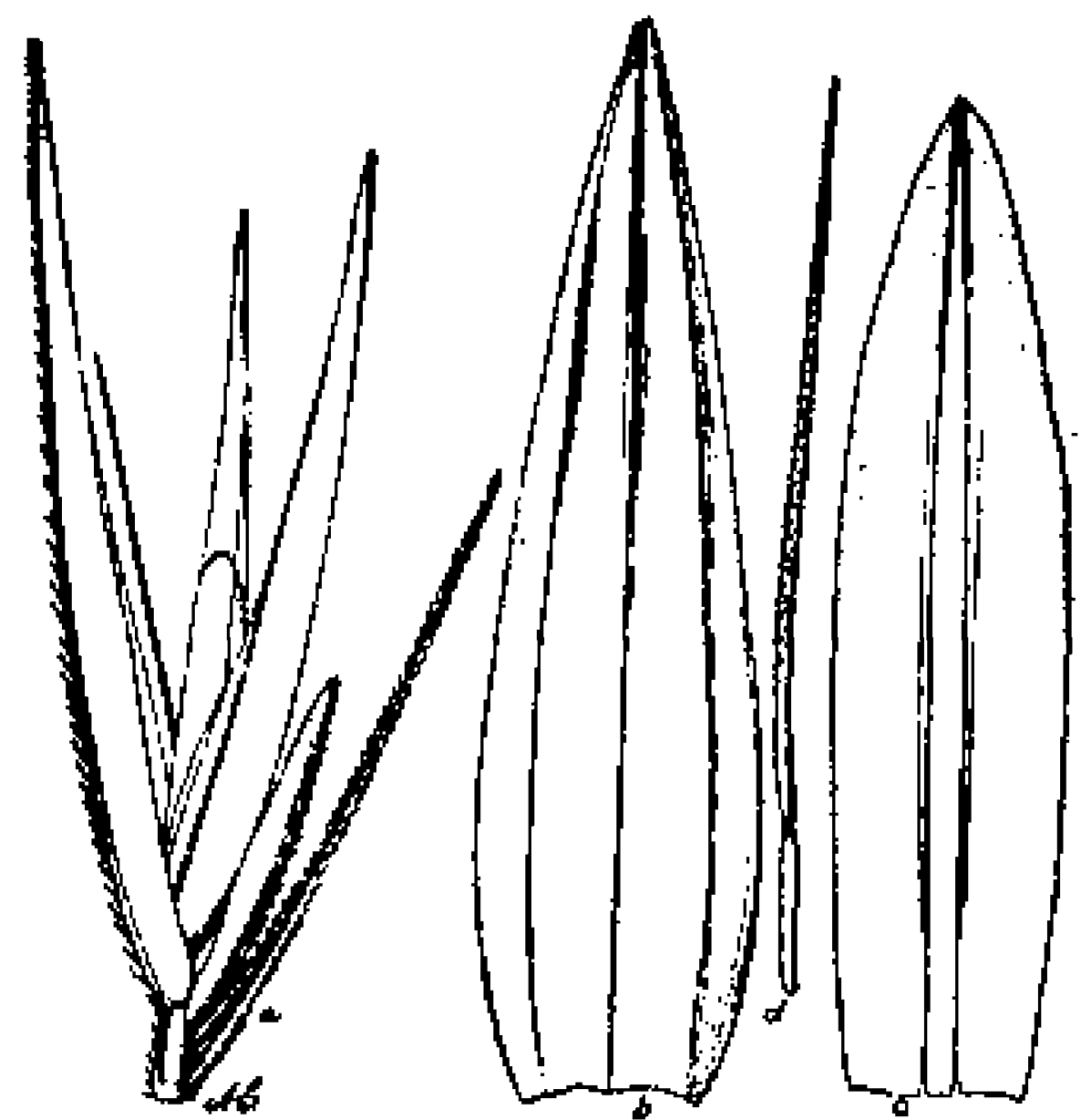

Fıg. 62.-Boutcloua uniflora. a, Spike, of single spikelet with prolongation of rachis; $b, c$, lemma and palet; $d$, rudiment. $a$, Scale $5 ; b-d$, scale 13 . From type specimen. representatives of which are in the Gray Herbarium. Some of them might be considered annual, but no. 507 is clearly perennial. In general aspect this certainly looks like $B$. curtipendula.

\section{Bouteloua uniflora Vasey.}

Boutcloua unifora Vavey, Bot. Gaz. 16:26. 1891. The type is Nealley 222, Crockett County, Texas, 1890, in the National Herbarium. Sce also U. S. Dept. Agr. Div. Agrost. Bull. 7 : 212. f. 194. 1897.

\section{DESCRIPTION}

A tall, amooth, tufted, erect poremial, with the habit and general appearance of $B$. curtipendula; culms simple or branched at the very base, 35 to $50 \mathrm{~cm}$. high; sheaths striale, snooth or minutely rough-hispid under a lens, the ligule reduced to a ring of short, flexuous, white hairs; blades variable, from $21010 \mathrm{~cm}$. long, the longest above, striate, minutely hispid, especially on the upper suritce and on the involute edges, the latter being also sparsely papillose-ciliate; panicle racemose, exactly like that of $B$. curtipendula excepting for the smaller spikes; spikes 25 to 35,8 to $9 \mathrm{~mm}$. long, consisting of a 1-flowered spikelet and a hispid, closely appressed prolongation of the rachis, about $4 \mathrm{~mm}$. long; second glume 7 to 8 $\mathrm{mm}$. long, $1 \mathrm{~mm}$. wide, acuminate, the first about $3 \mathrm{~mm}$. long, $0.8 \mathrm{~mm}$. wide, with a more rounded apex; lemma smooth, 3-nerved, very sliort-awned or awnless, about $6 \mathrm{~mm}$. long, with a narrow, 2-toothed, smooth palet, about $5 \mathrm{~mm}$. long; rudiment consisting of a single, simple, hispid awn about $4 \mathrm{~mm}$. long; caryopsis not known. (FIGURE 62.)

The specimen is immature, and it is barely possible that it may turn out to be an aberrant form of B. curlipendula. Bigelow, "Rio Sin Pedro, Texas," November 5, 1850 , in the herbarium of $S$. M. Tracy, from the Thurber IIerbarium, is the same as the type in every floral cletail, but the spikes are more numerous. No collections other than these two have been seen. 


\section{Bouteloua curtipendula (Michx.) Torr.}

Chloris curtipendula Michx. Fl. Ror. Amer. $1: 59.1803$. The type, collected in Illinois, is in the Michanx Jerbarium.

Bouteloua racemosa Lag. Vatr. Cienc. $2^{+}: 1+1.1805$. Iagas'a rites Chloris curtipendula as a synonym in his later paper."

Bouteloua pendula "H. R. M." Jag. Var. Cienc. 24: 141. 1805. A garden name published as a synonym of $B$. racemosa.

Atheropogon apludioides Muhl.; Willd. Sp. Pl. 4: 937. 1806; Jacq. Eclog. Gram. 8. pl.7. 1814; Roem \& Schult. Syst. Veg. 2:413. 1817; Spreng. Syst. Veg. $1: 293$. 1825. A good list of correctly referred synonyma is given by Jacquin.

Bouteloua melicaeformis Brauss.; Hornem. Enum. Pl. Hort, Hafn. 7. 1807. I follow Roemer and Schultes, ${ }^{b}$ who place this as a synonym under Atheropogon apludioides. Only a name is listed.

Bouteloua melicoides Beauv. Ess, Agrost. 40. pl. 9. f. 6. 1812. Based upon "Bout. melicoides HoRN." (evidently an error for "melicaeformis"). Beauvois's figurea, however, do not apply to $B$. curtipendula. They resemble more closely some speciee of the $B$. procumbens group. In his private copy of the Agrostographie Beauvois has written in his own haud "=Atheropogon apludioides." "This name was later listed, with Muhlenberg as the author, by Steudel c as a eynonym of Atheropogon apludioides.

Dineba curtipendula Beauv, Ess. Agrost. 98, 160. 1812. Presumably based upon Chloris curtipendula Michx., though Beauvois erroneously cites "Melica curtipendula Mucr." See also DC. Cat. Hort. Monsp. 105. 1813 (where the generic name is apelled "Dinebra"); H. B. K. Nov. Gen. \& Sp. 1 : 171 . 1816; Presl. Rel. Haenk, 1 : 292. 1830. Dineba melicoides? Beauv. Ess. Agrost. 160. 1812. A name only, given in the index. Atheropogon racemosus Roem. \& Schult. Syst. Veg. 2: 414. 1817. Based upon Bouteloua racemosa Lag.

Eutriana curtipendula Trin. Fund. Agrost. 161. 1820. Based upon (thlorig curtipendula Michx. See also Steud. Syn. Pl. Glum. 1 : 215.1854.

Melica curtipendula Michx.; Steud. Nom. Bot. 1:91, 519. 1821. Based upon Chloris curtipendula Michx. This name was earlier orroneously given by Beauvois (Bee above under Dineba curtipendula).

Bouteloua curtipendula Torr. in Emory, Mil. Reconn. 154. 1848; U. S. Dept. Agr. Div, Bot. Bull. $12^{1}$ : pl. 49. 1890; Britt. \& Brown, Illust. Fl. 1 : 180.f. 419. 1896; U. S. Dept. Agr. Div, Agrost. Bull. 7 : 213.f. 195. 1897.

Futriana affinis Hook. f. Trans. Linn. Soc. Bot. 20 : 174. 1851; Steud. Syn. Pl. Glum. 1 : 215 . 1854. The original description states that this is closely allied to E. curtipendula. Our present conception of this species would include the form described by Hooker. It is said to be identical with Atheropogon apludioides, Heterostegon curtipendulus, and Eutriana curtipendula of Schweinitz in the Hooker Herbarium. It is based upon Drummond specimens from Missouri and Texas.

Heterostegon curtipendulus Schwein.; Hook. f. Trans. Linn. Soc. Bot. 20 : 175.1851.

A name only.

Bouteloua curtipendula aristosa A. Gray, Man. Bot. ed. 2.553. 1856. This is the typical form in the mountains of the Southwest, but even there the awns often drop off toward maturity. One can establish many varieties in any of these species if he choose, but it appears better not to recognize this form as a subepecies.

Atheropogon curtipendulus Fourn. Mex. P1. 2 : 138. 1881. Based upon Bouteloun curtipendula A. Gray. Schaffner 535 and Bourgeau 2755, cited by Fournier, are in the herbarium of the St. Petersburg Botanical Garden.

a Gen. \& Sp. Nov. 5. 1816. b Sygt. Veg. $2: 414.1817$. c Nom. Bot. $1: 117.1821$. 
Eutriana racemosa Trin.; Fourn. Mex. Pl. 2: 141. 1881. A name only. According to Hitchcock's notes on the Trinius Herbarium, Trinius's specimen labeled F. racemosa is there put in the cover with $B$. curtipendula, to which species it belongs. (See Triathera gracilis under Triaena juncea.)

Atheropogon afinis Fourn. Mex. Pl. 2: 141. 1881. Based upon Eutriana affiris Hock.

\section{DESCRIPTION.}

A tall, erect, cespitose perennial, 50 to $80 \mathrm{~cm}$. high, spreading by strong, scaly, creeping rootstocks; sheaths rather close, prominently striate, smooth, the ligule ciliate-fringed; blades abundant, 10 to $30 \mathrm{~cm}$. long, smooth or very minutely scabrous, about equally distributed over the culm; panicle racemose, 15 to $25 \mathrm{~cm}$. longr, with

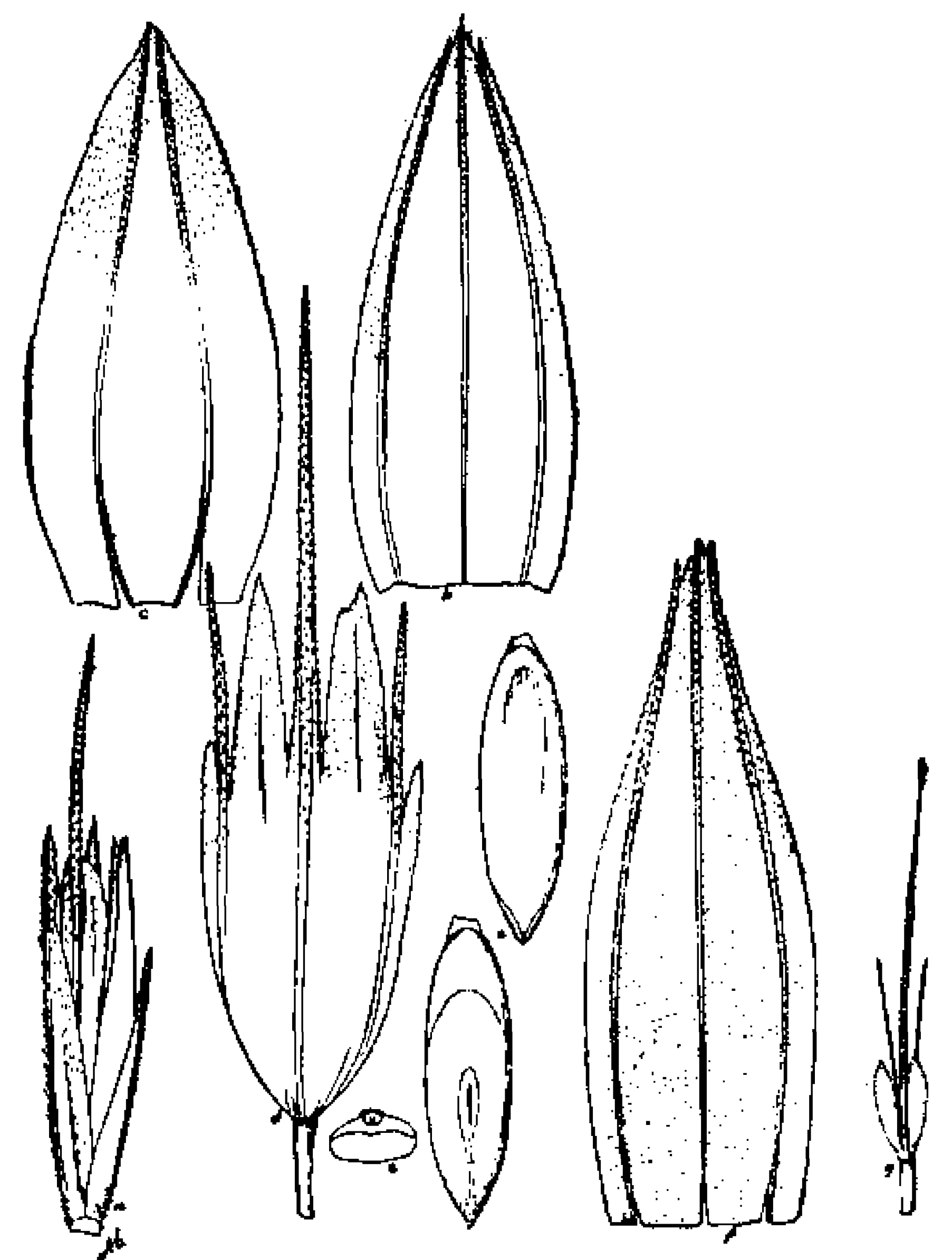

F10. 63.-Boutcloua curtipendula. a, Spikelet; b, c, lemina and palet of first foret; $d$, rudimentary second foret; $e$, two views and cross section of earyopsis; $/, g$, lemmut and rudiment from a diJterent plant. $a$, Scale $i ; b-a$, wale $8 . a-e$, From Griffits $=211 ; f, g$, from Griffith iot1.$$
\text { Drent from Illingis and Ontario westward and gouth }
$$
flatened axis; spikes 35 to 50 , bilaterally arranged on the flattened axis, but the delicate peduncles so twisted and curved as to make them unilateral, 1 to 2 cm. long; spikelets bilateral on a flattened rachis, but not pectinate, 5 to 8 , consisting of one fertile floret and a rudiment; glumes scabrous-keeled, the first 4 to $5 \mathrm{~mm}$, the aecond about 7 $\mathrm{mm}$. long; lemma minutely 3 awned, the central awn but little longer than the lateral, 5 to $6 \mathrm{~mm}$. long, smooth to slightly arabrous on the nerves toward the apex; palet acuminate, scabrous above; the rudiment reduced to a miltute scale with a delicate acabrous awn, and a rudimentary palet consiating of 2 very delicate awns; caryopsis elliptical, about 4.5 $\mathrm{mm}$. long, $1.5 \mathrm{~mm}$. wide, the scutellum covering two-thirds to three-fourthe of tho ventral surface. (Plate 69, A, facing p. 345; 82, B, facing p. 413. Fioure 63.) The common "side-oat grama" has a distribution in area second only to $B$. hirsuta. It is abundant from Illinois and Ontario westward and southward far into South America and has been collected as far east as New York and Connecticut, It is an important native forage in many places. Being of good quality and a large, vigorous grower, it is one of the most promising epecies for domestication, but, like all the others of this genus, it has the important disadvantage of poor seed habits. Besides being produced in small amount, the seed is difficult of separation from the chaff. In all attempts that have been made to establish meadows of it $\rightarrow$ and there have been a number in an experimental way-no attempts have been made to thrash the seed at all. The spikes, which readily eeparate from the culms of maturity, bavo been gathered and sown. 
The species is distinct and characteristic, and there are none with which it may be easily confused. Its general aspect is distinct and easily recoguized, but the minuter characteristics of the spikelets are most variable. The above description was drawn from Griffith 7071 , which corresponds very imperfectly with the drawings of Griffiths 7261, published herewith, expecially in the charucter of the rudiment. The latter form is the variety aristosa, which it does not seem wise to recognize as a subspecies on account of its extremo variation and the intergradations between it and the typical form.

As would be expected in a plant of such wide distribution, there are great variations in many if not all of the ordinary taxonomic characters. The accompanying text figures show some of these in so far as they relate to the floral structures. As a rule, the general plant body would be pronounced smooth, but often the leaves and sheaths are quite densely papillose-hairy. A specimen collected by Dr. Short in Kentucky ("Knob of the Crab Orchard"), and another, MacDougal 273, Flagstaff, Arizona, both show the development of this character. It frequently occurs that the leaves have conspicuously serrate edges or have regularly placed papillose hairs on the edges. Shear 707, Osborne, Kansas, is a good example of the development of the latter character. A specimen collected by Eggert in Jefferson County, Missouri, August, 1891, in the herbarium of the Missouri Botanical Garden, has pronounced papillose hairs on the edges of the leaves and very wide spikes, but other plants of the same collection - have short spikes and look very peculiar for this species. A specimen in the aame herbarium, collected by Bush in McDonald County, Missouri, July 24, 1903, is especially hairy on both the leaves and the sheaths. This condition is to be distinguished from that of the Eggert specimen above. The hairs are papillose also, but occur on the lower side of the leaves and the upper portion of the sheaths. There is none of - this in the Eggert specimen. A epecimen from Eggert in same herbarium from St. Clair, Illinois, is very similar to the Bush plant.

\section{HERBARIUM SPECIMFNS.}

ArIzons: Blumer 1671, (hiricahua Mountains. Hitchcock 3497, Tucson; 3655, Patagonia. Tidestrom 925, Jerome Junction. Nealley 1661, Monmouth, Rincon Mountains. MacDougal 799, Dos Cabezos; 273, Flagstaff. Parish 318. Chase 5825, Indian Gardeus, Grand Canyon. Griffths 3373, Santa Rita Forest Reserve; 1438, Benson; 1837, Dragoon Mountains; 1907, Cochise. Holzner 1569, Huachuca Mountains. Knowlton 1961, San Francisco Mountains. Davidson 306, Clifton. Griffith \& Thornber 188 and 189, Santa Rita Mountains. Leiberg 5734, San Francisco Mountains. Jones 6066, Canaan Ranch. Mearns 859, 1065, eouth of Bisbee; 1118, San Pedro River, Mexican Boundary. Zuck 30, Holbrook.

CaLfFornia: Hall 2138, San Jacinto Mountains.

Colonado: Chase 5310, Manitou; 5408, Las Animas County. Tidestrom 66, Hugo. Clements (Herb. Form. Colo.) 2. Crandall 3541, Fort Colling. Hitchcock 1792, Pikes Peak. Jones 548, Morrison. Tweedy 376, Durango, Grifhths 3311, Rocky Ford. Shear 969, Canyon City; 948, Salida. Wrilliams 2165 and 2120, Colorado Springs. Baker, Earle \& Tracy 970, Durango.

Connecticur: Bissell, Housatonic River near Oxford.

Inunois: Hill 181 in 1896, Will County. V. H. Chase, 1875, Princeville. Gleason 1001, Havana. McDonald 60, Peoria. Skeels 534, Joliet. Waite, Ogle County in 1887. Wilcox 62, Manitou.

IndIANA: Dormer 58, Elston.

Iown: Fink 433, Fayette. Morris A255, Murray to Thayer. Pammel \& Cratty 756, Ledyard. Ball 1008, Manchester. Pammel 645, Des Moines. 
Kansas: Hitcheock 3852, Manhattan. Stevens (in Seymour'a Grasses) 32, Manhattan. Smyth 285, Caldwell; 60, Hutchinson. Shear 146, 707, Osborne. Norton 910, Riley County. Thompson 127, Syracuse; 57, Ulysses.

Mrchana: Wheeler, Jackson County.

Mrinesota: Moyer, Montevideo. Mearns 738, Fort Snelling.

Mrssissippi: Tracy 1392, Starkville.

Montana: Blankinship 172, Upper Big IIorn River.

Nebraska: Rydberg 2521, North Platte; 1499, Thomas County. Clements 2701, Brazile Creek.

New Jersey: Van Sickle (July 27, 1893), Zinc Mincs. Porter, below Philipsburg.

New Mexico: Wooton \& Standley 3525, Lincoln County; 3979, Jona Ana County. Hitchcock 3802, Organ Mountains. Standley 4904, San Miguel County. Fisher 17, Tucumcari. Eurle 97 and 94, Gray. Wooton 337, Lincoln County; 2945, Fairview; 2922, Santa Fe; 1096, Organ Mountains. Metcalfe 640, Mangas Springs. Mearns 345, While Water.

North Dakota: Stockbridge 1875, Fargo. Brannon 107, Minot. Geyer (1839), near Devils Iake.

New York: Wibbe, Schenectady.

Ohuo: Moselcy, Marblehead.

Pennsylvania. Commons 324, Birmingham. Heller \& Halbach 704, Lancaster County. Pennell 569, Chescer County.

Souti Da кota: Bruce 14, Jamesville, Yankton County. Wallace 9, Indian Creek; 10, Medicine Horse Creek. Griffiths 61, Frankfort; 67, Redfield; 285, White Horse Creek; 768, Pierre, 83, Aberdeen. Wilcox 4, Brookings,

Texas: Ball 1152, Chillicothe. Tracy 8106, Abilene; 7744, Pierce. Heller 1762, Kerrville. Jermy 94, San Antonio. Wright 756, West Texas, Hall 772, Dallas. Bailey 741, Guadalupe Mountains. Plank 94, Del Rio; 66, El Paso. Mcarns 1212, Fort Clark. Lindheimer Exsic. 568. Nealley, College Station.

Uta H: Jones 5700, Capitol Wash.

Wroming: Chase 5272, Sundance. A. Nelson 530, Whaten Canyon; 8432, Laramie County. Grifiths 525, Devils Tower; 697, Newcastle; 494, Sundance; 410, Beulah: E. Nelson 479, Laramie County. Williams 2587, Sundance.

Mexico: Palmer 503, Jalisco; 114 and 206, Chihuahua; 861, Carmen Island; 371 and 407, Saltillo; 264, Conception del Oro; 194, Durango, Lloyd 201, 239, 213, Cedros, Zacatecas. Iitchcock 3609, Hermosillo; 3633, Nogales, IIolway 10, Tula. Pringle 408, Chihuahua. Schumann 1721, Parral, Pittier 444, Esperanza. Brandegee, San José del Cabo, Lower California. Mearns 1039, San José Mountains, Sonora; 2305, near White V'ater, New Mexico; 520, San Luis Mountains. Seaton 113, Orizaba. Smuth 958, Onxaca. Bourgeau 491, Santa Fe. Liebmann 580, Tehuacan. Orcutt 671, Topo Mountains, Lower California. Nelson 1799, Cuicatlan; 6247, Colonia Garcia, Chihuahua. Rose 2929, Bolanos, Jalisco.

Canada: Herriot, Galt, Ontario.

Guatemala: Iyde \& Lux 3930 (in J. D. Smith's Plants of Guatemala.)

South America: Bang 998, Bolivia. Stuckert 5877, Argentina. Pittier 1529, Colomhia.

\section{EXCLUDED NAMES.}

The following names belonging to or likely to be looked for in this group are excluded for the reasons enumerated:

Aristida minuta Poit,; Roem. \& Schult. Syst. Veg. 2 : 711. 1817. Listed as a eynonym of Dineba secunda.

Aristida secunda Ledeb.; Steud. Nom. Bot. ed. 2. $1: 132.1840$. Given as a synonym of Eutriana ledebourii. 
Atheropogon antillarum Spreng. Syst. Veg. $1: 294$. 1825. Aristida antillarum Poir. is cited as a synonym. Probably a species of Aristida from the West Indies.

Atheropogon medius Fourn. Mex. Pl. 2 : 139. 1881. This may be a form of Bouteinua aristidoides, but it can not be determined with any degree of certainty.

Atheropogon villosus Steud. Nom. Bot, ed. 2. 1:167. 1840. The name is credited to "Nees" and given as a synonym of "Eutriana villosa."

Chondrosium virletii Fourn. Mex. Pl, 2 : 136, 1881. I have not been able to find authentic material of this, although specimens are cited. The type is Virlet 1373, from San Luis Potosi, Mexico. Some portions of the description suggest a form of $B$. trinii.

Chondrosium subscorpioides C. Müll. Bot. Zeit. 14: 347. 1856. This is probably Bouteloua gracilis, but there is nothing certain about it. It is from California.

Corethrum Vahl, Skrivt. Naturh.-Selsk (Kjøbenhavn) 6:85. 1810. This is listed in the Index Kewensis as a synonym of Bouteloua, but both the description and the locality (Syria) indicate that it does not belong to this group.

Corethrum bromoides Vahl, Skrivt. Naturh.-Selsk. (Kjøbenhavn) 6: 85. 1810. The Index Rewensis refers this to Bouteloua bromoides, but the description does not admit the plant into this group.

Cynosurus retroflexus Vahl, Symb. Bot. $2: 20$. 1791. This is from the East Indies. Both the locality and Vahl's description indicate that it does not belong to this group.

Cynosurus secundus Pursh, Fl. Amer. Sept. 2 : 728. 1814. It is not possible for me to identify this from the description. It is probably not a member of our group, although by some it has been referred to $B$. curtipendula. It may be said that $B$. curtipendula is listed by Pursh under two other genera, viz, Atheropogon and Chloris. Nuttall a refers this doubtfully to Atheropogon apludioides.

Dactylis paspaloides Willd.; Kunth, Rév. Gram. 1:91. 1829. Given as a synonym of Leptochloa arabica. This has been erroneously referred to this group by some authors.

Deyeuxia brasiliensis Steud, Nom, Bot. ed 2. 1:620. 1840. A name from Sprengel's herbarium given as a synonym of Eutriana villosa according to Trinius's manuseript.

Dinebra Jacq. Fragm. 77. pl. 121.f. 1. 1809. This is a genus of Chlorideae to which various authors have referred species of Bouteloua, but which is not allied to this group. Beauvois $b$ spells the name Dineba (the original Arabic spelling) giving Delile as the author, and this spelling is followed by Presl. Kunth spelled the name ay did Jacquin.

Dineba aegyptica Delile, Descr. Egypt. 4 : 26. pi. 11.f. s. 1813. This does not belong here, although repeatedly placed here in the past.

Dineba arabica Beauv. Ess. Agrost. 98. pl.16.f. 2. 1812. The plant figured by Beauvois does not belong in this group. See Bentham's opinion of this. $c$

Dinebra brevifolia Steud. Syn. Pl. Glum. $1: 299.1854$. This is from Abyssinia, and probably is not a member of this group.

Dinebra calycina Wight; Nees, Proc. Linn. Soc. 1 : 95. 1841. A Wight herbarium name published as a synonym of Plagiolytrum calycinum, which is a plant from India.

Dineba chloridea Presl, Rel. Haenk. 1 : 291. 1830. According to the specimen at Prague this is not a Bouteloua, but probably a Chloris.

Dineba lima Beauv. Ess. Agrost. 98, 160. 1812. Beauvois cites this doubtfully under this genus. The combination is made in his index.

Dineba paspaloides Willd.; Beauv. Ess. Agrost. 98, 160. 1812. A name only, probably based upon Dactylis paspaloides Willd. Willdenow cites Dinebra arabica and Cynosurus retroflexus as synonyms of Dactylis paspaloides.

Dinebra retroflexa Panzer, Denkschr. Akad. Wiss. (München) 4: 270. 1814. Based on Dactylis paspaloides Willd.

a Gen. P1. 78. 1818.

$b$ E89. Agrost. 98. 1812. c Journ. Linn. Soc. Bot. 19 : 104. 1881.

d Enum. Pl. 111. 1809. 
Dinebra secunda Roem. \& Schult. Syst. Veg. 2:711. 1817. Based upon Cynosurus secundus Pursh.

Dinebra verticillata Wirht; Stend. Syn. Pl. Glum. $1: 209$. 1854. A name cited as synonym of Leptochloa wightiana. It is from India and probably not a member of this group.

Enteropogon melicoides Nees; Steud. Syn. Pl. Glum. $1: 216.1854 . \Lambda$ manuscript name published as a synonym of Eutriana enteropogon.

Erucaria Cervantes, la Naluraleza (Mexico City) $1: 347,1870$. There is no way of determining with any certainty what the epecies described are, and consequently they must be rejected. It is not certain that all of the species belong to this group. Cervantes proposed the following names: Erucaria glandulosa, E. villosa, F. hirsuta, E. lutescens, E. monostachia, E. tetrastachia, E. longifolia, and E. glabra. Fournier has suggested that $E$. glabra is $B$. curtipendula. The description of $E$. glandulosa and $E$. hirsuta both suggest $B$. hirsuta. Erucaria lutescens and $E$. monostachia suggest B. procumbens or B. scorpiodes. Erucaria villosa may be B. chondrosioides. Erucaria tetrastachia may be $B$. gracilis.

Eutriana antillarum Steud. Syn. P1. Glum. 1 : 217. ]854. Based upon "Aristida antillarum Lam."

Eutriana? chloridea Kunth, Enum. P1. 1 : 280. 1833. Based upon Dineba chloridea Presl.

Eutriana karwinskiana Steud. Nom. Bot. ed. 2. 1 : 620. 1840. A name only, from Trinius's manuscript.

Eutriana ledebourii Trin. Gram. Unifl. 238. 1824. AIthough citing Dinebra secunda Roem. \& Schult. (Cynosurus secundus Pursh) as a synonym, Trinius gives the habitat as St. Domingo. A specimen named E. ledebourii in the Trinius Herbarium, is doubtful. The spikelet is that of a Bonteloua, but the spikes have but a single spikelet. It does not seem probable, then, that this is the same as $B$. americana, but I am not able to decide without more material.

Eutriana melicoides Steud. Syn. Pl. Glum. 1: 216. 1854. The first synonym cited is an East Indian plant.

Eutriana villosa Steud. Nom. Bot. ed. $2.1: 620.1840$. No description is given, and the synonyms are only manuscript names.

Ischaemum melicoides Koenig; Willd. Sp. Pl. 42: 941. 1806; Steud. Syn. Pl. Glum. 1: 216. 1854. Steudel cites this name as a synonym of Eutriana enteropogon. The plant is from India and probably does not belong in this group. Jacq.

Leptochloa arabica Kunth, Rév. Gram. 1: 91. 1829. Based upon Dinebra arabica

Pappophorum alopecuroideum Vahl, Symb. Bot. $3: 10$. pl. 51. 1794. This has been referred tc Bouteloua megapolamica, but Vahl's figures show it to be true Pappophorum.

Tripogon bromoides Roth, Nov. Pl. Sp. Ind. Or. 79. 1821. The generic description excludes Bouteloua; Roem. \& Schult. Syst. Veg. 2:600. 1817. An earlier mention of the name based on Triathera bromoides Roth in manuscript. 


\section{LIST OF SPECIMENS DEPOSITED IN PUBLIC HERBARIA. ${ }^{a}$}

Hitchcock 6074. Triaenra juncea. Tehuacan, Mexico, August 9, 1910.

Griffiths 8117. juncea. Dublan, II idalgo, Mexico, September 7, 1905.

8122. juncea. Dublan, II idalgo, Mexico, September 7, 1905.

8408. juncea. Saltillo, Mexico, August 17, 1906.

Hitchcock 6776. Cathestecum crectum. Balsas, Mexico, September 9, 1910.

Griffiths 6834. erectum. Imuris to Santa Ana, Sonora, Mexico, August 18-19, 1904.

multifidum. Iguala, Mexico, September 9, 1909.

IIitchcock 6164. multifidum. Oaxaca, Mexico, August 12, 1910.

6072. stoloniferum. Tehuacan, Mexico, August 9, 1910.

Griffiths 9764. stoloniferum. Tomellin, Mexico, September 31, 1909.

5918. Bouteloua aristidoides. Santa Rita Mountains, Arizona, September 27-October $3,1903$.

6096. aristidoides. Deserls of Tucson, Arizona, October, 1903.

6097. aristidoides. Deserts southeast of Tucson, Arizona, October, 1903.

6158. aristidoides. East of Tucson, Arizona, October 13, 1903.

7014. aristidoides. Mesas east of Tucson, Arizona, September 4, 1904.

7126. aristidoides. Mount Lemmon, Santa Catalina Mountains, Arizona, September 8, 1904.

7278. aristidoides. In depressions, southeast of Tucson, Arizona.

7286. aristidoides. Southeast of Tucson, Arizona, September 20, 1904 .

7302. aristidoides. In depressions, aoutheast of Tuceon, Arizona, September 21-23, 1904.

7308. aristidoides, Favorable places, east of Tucson, Arizona, September 21-23, 1904.

7309. aristidoides. Favorable places, east of Tucson, Arizona, September 21-23, 1904.

9862. aristidoides. Durango, Mexico, September 28, 1909.

Wooton 3063. barbata. Mesilla Park, New Mexico, October 20, 1904.

Griffithe 5108. barbata. In irrigated yard, Adamana, Arizona, August 6, 1903.

5112. barbata. Adamana, Arizona, August 6, 1903 ,

5809. barbata. Near Navajo, Arizona, September 13, 1903.

6095. barbata. Suutheast of Tucson, Arizona, October, 1903.

6208. barbata. Thornton, New Mexico, October 19, 1903.

6541. barbata. Laredo, Texas, June 14, 1904.

6861. barbata. Imuris to Altar, Sonora, Mexico, August 19, 1904.

6890. barbata. Altar, Sonora, Mexico, Auguat 20, 1904. (Close to B. arenosa.)

6905. barbata. Altar, Sonora, Mexico, August 20, 1904. (Cloee to B. arenosa.) 
Griffiths 7140. Bouteloua barbata. Mount Lemmon, Santa Catalina Mountaina, Arizona, September 8-0, 1904.

7156. barbata. Mount Lemmon, Santa (atalina Mountains, Arizona, September 8-9, 1904.

7157. barbata. Mount l, cmmon, Santa Catalina Mountains, Arizona, September 8-9, 1904.

7176. barbata. Tucson, Arizona.

7303. barbata. Mesas near Tucson, Arizona, September 23, 1904.

7323. barbata. Prescott, Arizona, September 26, 1904.

7404. barbata. Las Cruces, New Mexico, October 6, 1904.

8116. barbata. Dublan, Mexico, September $7,1905$.

9861. barbata. Dublan, Mexiro, September $7,1905$.

5717. breviseta. East of Roswell, Now Mlexico, September 2, 1903.

5758. breviseta, Blufls of Pecos River near Roswell, New Mexico, September 4, 1903.

Uitchcock 6150. Griffiths

5871. chondrosioliles. Oaxara, Mexico, August 12, 1910.

chondrosioides. San Antonio, Michoacan, Mexico, August 21, 1909.

27-October 3, 1903.

6124. chondrosioides. Salero Hills, Santa Rita Mountains, Arizona, October 8, J903.

6732. chondrosioides. Tubac, Arizona, August 15, 1904.

6790. chondrosioides. Cocospora Ranch, Sonora, Mexico, August 17, 1904.

6925. chondrosioides. Isaosa, Arizona, August 24, 1904.

7266. chondrosioides. Santa Rita Mountains, Arizona, September $17,1904$.

7270. chondrosivides. Santa Rita Mountains, Arizona, September $17,1904$.

9742. chondrosioides, Oaxaca, Mexico, September, 1909.

9863. chondrosioides. Durango, Mexico, September 28, 1909.

Chase, V.H.1875.

Grifliths 5614. curtipendula. Princeville, Pcoria County, Illinois, July 8, 1908.

7071. curtipendula. Santa Catalina Mountains, Arizona, September $5-10,1904$.

7261. curtipendula. Santa Rita Mountains, Arizona, September 17, 1904.

eludens. Santa Rita Mountains, Arizona.

6746. eludens. Near Nogales, Sonora, Mexico, August 16, 1904.

6789. eludens. Cocuspora Ranch, Sonora, Mexico, A ugust 17, 1904.

6947. eludens. Santa Rita Mountains, A rizona, September 29, 1904.

7051. eludens. Santa Catalina Mountains, Arizona, September 5, 1904.

7269. eludens. Santa Catalina Mountains, Arizona, September 18, 1904.

5573. eriopoda. Cimarron Canyon, New Mexico, August 23, 1903.

5968. eriopoda. Santa Rita Mountains, Arizona, September 27October 3, 1903.

7002. eriopoda. Santa Rita Mountains, Arizona, August 31, 1904.

7186. eriopoda. Santa Rita Mountains, Arizona, September 13-21, 1904.

filiformis. El Llano, Jalisco. Mexico, September 16, 1909. 
Hitchcock 5827. Bouteloua filiformis. Querétaro, Mexico, July 24, 1910.

5827a. filiformis. Querétaro, Mexico, July 24, 1910.

Griffiths 5916. filiformis. Santa Rita Mountains, Arizona, October 3, 1903.

6397. filiformis. Encinal, Texas, May 20, 1904.

6791. filiformis. Cocospora Ranch, Sonora, Mexico, August 17, 1904.

7178. filiformis, Santa Catalina Mountains, Arizona, September 10-12, 1904.

7179. filiformis. Santa Catalina Mountains, Arizona, September $10-12,1904$.

7199. filiformis. Santa Rita Mountains, Arizona, September 13-21, 1904.

5187. gracilis. Cimarron Canyon, New Mexico, August 9, 1903.

5236. gracilis. St. Johns to White Mountains, Arizona.

5472. gracilis. Raton Mountains, New Mexico, August 18, 1903.

5627.

6108 .

6710 .

gracilis. Texlinc, Texas, August 27, 1903.

9809 .

gracilir. Sonoyta Valley, Arizona, October 7, 1903.

gracilis. Colorado Springs, Colorado, August 6, 1904.

5523. gracilis. Dublan, Mexico, September, 1909.

hirsuta. Lamy, New Mexico, August 31, 1910.

5572 ,

5628 .

hirsuta. Cimarron Canyon, New Mexico, August 21, 1903.

5743 .

hirsuta. Cimarron Canyon, New Mexico, August 23, 1903.

hirsuta. Texline, Texas, August 27, 1903.

tember 4, 1903.
$6079 . \quad$ hirsuta. Santa Rita Mountains, $\Lambda$ rizona, October 3, 1903.

6125. hirauta. Salero Mountains, Arizona, October 8, 1903.

6709. hirsuta. Colorado Springs, Colorado, August 6, 1904.

6792. hirsuta. Near Cocospora Ranch, Sonora, Mexico, August 16, 1904.

7263. hirsuta. Santa Rita Mountains, Arizona, September 17, 1904. hirticulmis. El Llego, Jalisco, Mexico, September 19, 1909.

9849. hirticulmis. Aguascalientes, Mexico, September 29, 1909.

Wooton 3065. parryi. Mesas near Mesilla Park, New Mexico, October 25, 1904.

Griffiths 5940 .

parryi. Santa Rita Mountains, Arizona, September 27-October 3,1903 .

7001. parryi. Santa Rita Mountains, Arizona, August 31, 1904.

7277. parryi. Santa Rita Mountains, Arizona, September 17, 1904.

7421. parryi. Near Mesilla Park, New Mexico, October 6, 1904.

7422. parryi. Near Mesilla Park, New Mexico, October 6, 1904.

7423. parryi. Near Mesilla Park, New Mexico, October 6, 1904.

9614. parryi. Santa Rita Mountains, Arizona, September 21, 1908.

5110. procumbens. Adamana, Arizona, August 6, 1903.

5222. procumbens. St. John'a to White Mountains, Arizona, August $10,1903$.

5255. procumbens. White Mountains, Arizona, A ugust 11-15, 1903.

5277. procumbens. White Mountains, Arizona, August 11-15, 1903.

5501. procumbens. Raton Mountains, New Mexico, August 18, 1903.

5502. procumbens. Raton Mountains, New Mexico, August 18, 1908.

5585. procumbens. Cimarron Canyon, New Mexico, August 24, 1903.

6724. procumbens. Manitou, Colorado, August 7, 1904.

6725. procumbens. Manitou, Colorado, August 7, 1904.

7362. procumbens. Flagstaf, Arizona, September 28, 1904.

8139. procumbens. Zacatecas, Mexico, September 19, 1905.

9516. procumbens. Prescott, Arizona, August 31, 1908. 
Hitchcock 6780. Bouteloua radicosa. Balsas, Mexico, September 9, 1910.

Griffiths 7012. radicosa. Cultivated at Tucson, Arizona, September 2, 1904.

7050. radicosa. Santa Catalina Mountaine, Arizona, September 5-10, 1904.

7180. radicosa. Santa Catalina Mountains, Arizona, September 10$12,1904$.

7181. radicosa. Santa Catalina Mountaing, Arizona, September 1012,1904 .

7198. radicosa. Santa Rita Mountains, Arizona, September 15, 1904.

8124. radicosa. Dublan, IIidalgo, Mexico, September, 1905.

Hitchcock 7040 .

Grifliths 1556 .

4402 .

6111.

6149 .

6153.

6159.

6796.

7185.

7279 .

Hitchcock 6272 .

Griffiths 8460 .

8461 .

8462 .

8527.

8054 .

6294.

6370.

6545 .

4112.

6104.

6283.

6337.

6338.

6339 .

6372 .

6366 .

6429 .

6430 . repens. Manzanillo, Mexico, August 20, 1910.

rothrockii. Fort Lowell, Arizona, September, 1900.

rothrockii. Sanla Rita Mountains, Arizona, May 23, 1903.

rothrockii. Cottonwood, Arizona, October 7, 1903.

rothrockii. Baboquivari Mountains, Arizona; October 10, 1903.

rothrockii. Robles Ranch, Pima County, Arizona, October 11, 1903.

rothrockii. Mesas near Tucson, Arizona, October 13, 1903.

rothrockii. Near Cocospora Ranch, Sonora, Mexico, August 17, 1904.

rothrockii. Santa Rita Mountains, Arizona, September 13-21, 1904.

rothrockii. Andrade, Pima County, Arizona, September 20, 1904.

scorpioides. ('halchicomula, Mexico, August 19, 1910.

scorpioides. Canpero, Mexico, August 30, 1906.

scorpioides. (amporo, Mexico, August 30, 1906.

scorpioides. ('ampero, Mexico, August 30, 1906.

acorpioides. Encinillas, Mexico, September 13, 1906.

stolonifera. Alonzo, San Luis Potosí, Mexico, August 11, 1905.

texana. Spofford, Texas, May 8, 1904.

texana. Encinal, Texas, May 20, 1904.

texana. San Antonio, Texas, May 16, 1905.

trinii. Southern Texas.

trinii. Near 'Tucson, Arizona, April 20-25, 1903.

trinii. Andrade, Pima County, Arizona, October 6, 1903.

trinii. Spofford, Texas, May 8, 1904.

trinii. Eagle Pass, Texas, May 11, 1904. (Closely grazed.)

trinii. Eagle Pass, Toxas, May 11, 1904.

trinii. Eagle Pass, T'xar, May 11-13, 1904.

trinii. Encinal, Texas, May 20, 1904.

trinii. Encinal, Texas, May 20, 1904.

trinii. Torrecillas, Texas, May 24, 1904.

trinii. Torrecillas, Texas, May 24, 1904. 